ANDRÉ EDUARDO RIBEIRO DA SILVA

\title{
A Territorialização da Agroindústria \\ Sucroalcooleira: O processo de reestruturação produtiva no campo e os trabalhadores canavieiros da fazenda Amália /SP
}




\title{
A TERRITORIALIZAÇÃO DA AGROINDÚSTRIA SUCROALCOOLEIRA: \\ O processo de reestruturação produtiva no campo e os trabalhadores canavieiros da Fazenda Amália/SP
}

\begin{abstract}
Dissertação de Mestrado apresentada à Faculdade de Filosofia, Letras e Ciências Humanas da Universidade de São Paulo, como parte dos requisitos para a obtenção do título de Mestre em Geografia Humana, sob a orientação do Prof. Dr. Júlio César Suzuki.
\end{abstract}


Aos meus pais Vicente e Maria Aparecida, pela vida, pelas histórias ouvidas desde o berço sobre a Fazenda Amália, pela força e confiança sobrenatural sempre em mim depositadas. Pelos esforços imensuráveis e os conselhos que alimentam minha vida.

A meus irmãos Fábio, Maria Emília e Elaine pela energia contagiante, mais que necessária para eu "tocar o barco".

A Rosana, minha companheira, sempre por perto... Pela parceria e apoio incondicionais dados à feitura deste trabalho 


\section{Agradecimentos}

Aqui vão meus agradecimentos às muitas pessoas que de alguma forma contribuíram para que este trabalho fosse elaborado:

Aos companheiros do Programa de Pós-Graduação e do Laboratório de Geografia Agrária, pelas discussões compartilhadas, pela convivência enriquecedora do espírito.

Aos colegas de orientação: Amauri, Camilo, Elisa, Elisângela, Evandro, Giancarlo, Imário, Josoaldo, Lina, Márcio, Marli, Rogério, Samarone, Telma,Vânia e Viviane, pelos debates nos encontros de "colóquio" e pela amizade vivenciada no curto tempo, mas extensivas a toda uma vida.

Às lideranças do Sindicato dos Trabalhadores Rurais de Santa Rosa de Viterbo: Edna Clemente, Gleber Clemente, “Tim” e Elisângela sempre prestativos e de fundamental importância na indicação de depoentes, na aproximação com os trabalhadores rurais no espaço produtivo, nas observações diretas de campo realizadas nos canaviais. Sem a participação de vocês, a elaboração desse trabalho ficaria em muito prejudicada.

Aos funcionários das diversas instituições de pesquisa visitadas, a saber: Fundação Cultural de Santa Rosa de Viterbo, Instituto de Economia Agrícola, Arquivo Público e Histórico de Ribeirão Preto, Casa da Cultura de Cajuru, pela solicitez durante a fase da pesquisa histórica e iconográfica.

Aos técnicos da Usina Ibirá, que possibilitaram uma visitação técnica do pesquisador pela usina, fornecendo dados, imagens, auxiliando sempre no que fosse possível.

Aos funcionários dos Cartórios de Registros de Imóveis de Cajuru, Cravinhos, Santa Rosa de Viterbo, São Simão e Tambau, sempre prestativos, apesar das “caras e bocas” do pesquisador em razão da custosa despesa dos documentos.

Ao CNPq pela concessão de bolsa de mestrado (2005-2007).

À banca de qualificação, representada pelas professoras Dra. Maria Aparecida de Moraes Silva e Dra Ana Fani Alessandri Carlos, pelas contribuições que encorajaram o pesquisador e deram substância à redação final da dissertação.

Às meninas da secretaria do Programa de Pós-Graduação em Geografia Humana: Ana, Cida, Jurema e Rosângela, pela solicitez, mesmo na urgência do pedido de 
encaminhamentos para a pesquisa, e na alegria, com que anunciaram que "a bolsa de Mestrado chegou!”!

A André Freitas pela elaboração dos mapas e ao Jonatas pela tradução do resumo da dissertação.

Ao professor Dr. Júlio César Suzuki, pelo carinho, atenção e confiança dispendidas durante todo o trabalho.

Aos trabalhadores e trabalhadoras rurais das usinas Ibirá e Santa Rita, que gentilmente me recebeu em suas casas, com a disposição de falar um pouquinho, sobre a Fazenda Amália, mas que consumiu tardes agradáveis inteiras. Vocês foram a força inspiradora que moveu idéias e montanhas para a realização deste trabalho.

A todos vocês, o meu singelo e sincero Muito Obrigado! 


\section{Resumo}

Estas reflexões terão como base o processo de territorialização e reestruturação da produção e do trabalho na agroindústria canavieira, especificamente na cultura da cana-de-açúcar processada pelas Usinas Ibirá e Santa Rita, em terras que, no ano de 1993 faziam parte da Fazenda Amália, sediada no município de Santa Rosa de Viterbo, nordeste do estado de São Paulo.

Reestruturação da produção e do trabalho que impinge marcas, novas relações no território então dominado pelos canaviais. Marcas, relações que se fazem, dissipam-se e reconstroem-se historicamente. Para tanto nos apoiamos no conceito de território, interpretado como o espaço do político, portanto dotado de possibilidades de transformações e mudanças, cuja efetivação dependerá das forças dos sujeitos sociais empenhados nesta ação. Com isto, o território é marcado por lutas e contradições que se processam no interior da sociedade.

Dessa forma, pretendemos compreender, a partir dessa concepção de território, o processo de territorialização da agroindústria canavieira e as significativas reestruturações que perpassaram as esferas de produção tendo como base a Fazenda Amália.

Boa parte desta pujança da agroindústria canavieira se deve à grande disponibilidade de força de trabalho com baixos rendimentos, o que favorecia o processo de reprodução ampliada desse capital, assim como a consolidação do processo de territorialização do monopólio das agroindústrias canavieiras.

Assim, a analise tem como norte as implicações sociais do processo de reestruturação da produção e do trabalho nos canaviais para a vida dos sujeitos sociais, a qual não se encontra separada do trabalho, embora cada vez mais condenada a uma existência subalterna ou a uma condição humana negada, em que o trabalho é percebido como algo separado, estranho, sem sentido.

Geografia Agrária - Agroindústria canavieira - Reestruturação Produtiva Trabalhadores Rurais - Fazenda Amália 


\begin{abstract}
These reflections will be based the in territorialization and re-structure process of production and cane agrarian industry labor, specifically inside the sugar-cane culture processed by "Usina Ibirá" and "Usina Santa Rita" plants, on lands which, in the year of 1993, belonged to Amália Farm, headquarted at Santa Rosa de Viterbo city, northeast of São Paulo state.

Reorganization of production and labor, which imposes marks, new territorial relations, vanquished by sugar cane plantations. Boundaries, constructed relations, vanishes and reconstructs historically. To perform it we centered our studies on the concept of territory, read by the space of politics, endowed of possibilities of transformations and changes whose attainments will depend on the forces of social subjects exerted in this action. By that, territory is branded by struggles and contradictions processed inside society.

That way, we intend to comprehend, from this concept of territory, the process of territorialization of sugar cane agrarian industry, and the so significant reorganizations which crosses the entire production spheres based on Amália Farm.

A good part of the puissance of sugar cane industry owes its availability of labor forces with low incomes, which favors the extended capital reproduction process, as so the consolidation of territorialization process of monopoly of sugar cane industries.

Therefore, the analysis is compassed by the social implications of the reorganization process of labor and field work at the cane harvest to the lives of social subjects, which isn't apart from labor, however, immersed and doomed to a subaltern existence or a denied human condition, in which labor is felted as something aside, strange, senselessness.
\end{abstract}

Agrarian Geography - Sugar cane agrarian industry - Productive reorganization Husbandmen - Amália Farm. 


\section{Sumário}

Introdução .1

Capítulo 1 - A Fazenda Amália dos Matarazzo: Fides, Honor, Labor ......................18

1.1 A Formação da Fazenda Amália nos tempos de Dumont ..................................19

1.2 Sociedade Agrícola Fazenda Amália: ensaio da Era Matarazzo ........................35

1.3 A Fazenda de Amália de Matarazzo Júnior .......................................................41

1.4 No interior dos canaviais: as colônias de trabalhadores rurais ..........................65

Capítulo 2 - A territorialização da agroindústria canavieira nas décadas de 1970 e 1980 e a formatação do "bóia-fria” nas terras do Conde Matarazzo Jr. .................... 80

2.1 Seguindo a cartilha da "modernização conservadora”......................................81

2.2 A intensificação do assalariamento sazonal e da “cidade da usina”.....................89

2.3 O declínio das Indústrias Matarazzo e a concordata de Amália..........................108

Capítulo 3 - A Territorialização da Agroindústria canavieira na antiga Fazenda Amália na década de 1990 e início dos anos 2000

3.1 A Reestruturação Produtiva do Capital Sucroalcooleiro na antiga Fazenda Amália.

3.2 As Relações de Trabalho nos Canaviais.

3.3 A configuração fundiária da Fazenda Amália: herança do grupo Matarazzo e o processo de reestruturação produtiva do capital sucroalcooleiro .155

3.4 Usina Ibirá : organização territorial do capital e do trabalho no velho "mar de cana” .163

Considerações Finais .174

Referências .180 


\section{Lista de Tabelas}

Tabela 1 - Os maiores grupos usineiros paulistas das décadas de 1930 e 1940 ........52

Tabela 2 - Usina Amália - Produção de açúcar. Safras 1930/31 - 1949/50.

Tabela 3 - Estado de São Paulo e Brasil. Moagem de cana-de-açúcar nas usinas.

Safras 1950/51 - 1965/66

Tabela 4 - Usina Amália. Produção canavieira e sucroalcooleira. Safras 1951/52 $1965 / 66$ .62

Tabela 5 - Moradores das colônias rurais das seções da Fazenda Amália .66

Tabela 6 - Município de Santa Rosa de Viterbo/SP. População Urbana, Rural e das Seções da Fazenda Amália. Início da década de 1960 .68

Tabela 7 - Santa Rosa de Viterbo/SP. População Urbana e Rural (1940 - 2000).......90

Tabela 8 - Santa Rosa de Viterbo/SP. Estabelecimentos por grupo de área total (1996).

Tabela 9 - Configuração fundiária da Fazenda Amália em agosto de 1990 .112

Tabela 10 - Trabalhadores de algumas empresas e setores da S.A I.R.F. M., na

Fazenda Amália .156

Tabela 11 - Propriedades fundiárias adquiridas pelo grupo Irmãos Cury S.A na

Fazenda Amália em maio de 1992 157

Tabela 12 - Terras adquiridas pelo grupo Cury na Fazenda Amália em novembro de 1996 da Copersucar .158

Tabela 13 - Usina Ibirá. Produção sucroalcooleira (1998/99 - 2006/07) 166

Tabela 14- Usina Ibirá. Duração e período da safra canavieira(1998/99-2006/07)..169

Tabela 15 - Usina Ibirá. Número de trabalhadores(1998/99 - 2006/07) 170 


\section{Lista de Figuras}

Figura 1 - Estação ferroviária Santos Dumont (antiga estação Glória) na porção sul do atual município de Santa Rosa de Viterbo/SP ....................................................25

Figura 2 - Estação Ferroviária de Amália. ............................................................26

Figura 3 - Usina London, nos tempos de Dumont …...............................................29

Figura 4 - Barragem de Itaipava no início dos anos 1940 ....................................31

Figura 5 - Barragem de Itaipava no alvorecer do século XXI ................................32

Figura 6 - Miragem nos canaviais? Entrada do "palacete” nas terras vitalícias do Conde Matarazzo Júnior na Fazenda Amália. ...........................................................36

Figura 7 - "Porteira” da mansão dos Matarazzo no centro da cidade .........................38

Figura 8 - Destino privativo ao palacete. Portão da estrada particular que conduz ao "palacete" .39

Figura 9 - Colônia-sede da Fazenda Amália (Bella Vista), no fim dos anos 1930

Figura 10 - Sede da Fazenda Amália nos primeiros anos do século XXI . .44

Figura 11 - Fábrica de conservas e de amido de mandioca na seção Fazendinha.da Fazenda Amália . .46

Figura 12 - Locomotiva utilizada na Fazenda Amália, exibida na Praça Francisco Schmidt, em Ribeirão Preto .48

Figura 13 - Trabalhadores da ferrovia interna da Fazenda Amália. .49

Figura 14 - Integração produtiva em Amália. Fábrica de papel, instalada nas proximidades da Fazenda Amália com a designação de Indústria Matarazzo de

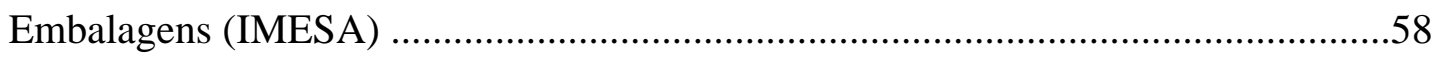

Figura 15 - Trabalhadores colhendo tomates .......................................................60

Figura 16 - Antigo Cine Dom Joanico ..................................................................69

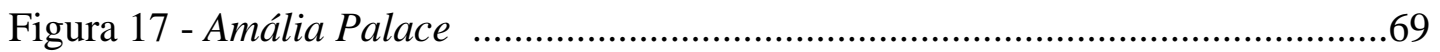

Figura 18 - Colônia de Alambari, no município de Cajuru /SP ...............................77

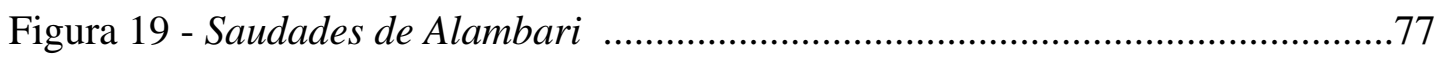

Figura 20 - Caminhão e carregadeira mecânica ......................................................85

Figura 21 - Trabalhadores migrantes. Pausa para o almoço no plantio da cana ....99

Figura 22 - A face oculta do trabalho nos canaviais paulistas .................................100 
Figura 23 - Greve vitoriosa

Figura 24 - Fotografia aérea da cidade de Santa Rosa de Viterbo

Figura 25 - Corte manual da cana crua: discussão social prolongada, desgaste garantido do trabalhador.

Figura 26 - Plantio de cana-de-açúcar. Antiga seção Santa Sofia da Fazenda Amália(hoje pertencente à Usina Santa Rita)

Figura 27 - Trabalhadores do "reflorestamento" da Usina Santa Rita, município de Santa Rosa de Viterbo

Figura 28 - Bituqueiras 148

Figura 29 - Espaço da água gelada, de deixar os bonés e guardar as ferramentas no ônibus rural 153

Figura 30 - Usina Ibirá, herdeira de Amália na produção de açúcar e álcool

Figura 31 - Dentro da usina, muitas máquinas, poucos operários .172 


\section{Lista de Mapas}

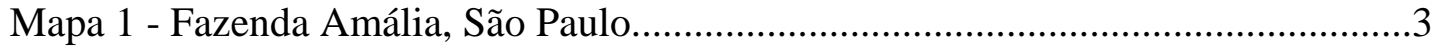

Mapa 2 - Antigo município de São Simão: situação geográfica no século XIX ....21

Mapa 3 - Fazenda Amália: delimitação aproximada ...............................................45 


\section{Lista de Siglas}

Abag - Associação Brasileira do Agronegócio

Abimaq - Associação Brasileira da Indústria de Máquinas e Implementos

Agrícolas

CDPA - Comissão de Defesa da Produção de Açúcar.

CEAM - Comissão de Estudos sobre o Álcool Motor

Contag - Confederação Nacional de Trabalhadores da Agricultura

COPERSUCAR - Cooperativa dos Produtores de Cana, Açúcar e Álcool do Estado de São Paulo.

FAPESP - Fundação de Amparo à Pesquisa do Estado de São Paulo.

FERAESP - Federação da Agricultura do Estado de São Paulo.

FETAESP - Federação dos Trabalhadores da Agricultura do Estado de São Paulo.

GERCA -. Grupo Executivo de Racionalização da Cafeicultura

IAA - Instituto do Açúcar e do Álcool.

IBC - Instituto Brasileiro de Café

IMESA - Indústria Matarazzo de Embalagens Sociedade Anônima

IMODSA - Industria Matarazzo de Óleos e Derivados Sociedade Anônima

Proálcool - Programa Nacional do Álcool.

SA IRFM -Sociedade Anônima Indústrias Reunidas Fábricas Matarazzo.

Unica - União da Agroindústria Canavieira de São Paulo. 


\section{Introdução}


Este trabalho significa em princípio, a continuidade dos estudos sobre o processo de territorialização da agroindústria canavieira na região de Ribeirão Preto a partir de pesquisa de iniciação científica, desenvolvida entre meados de 2000 a 2003, por meio de bolsa concedida pelo PIBIC/CNPq, sob a orientação do professor Dr. Ariovaldo Umbelino de Oliveira).

Esta pesquisa de iniciação científica foi base para a confecção do Trabalho de Graduação Individual (TGI), no qual propusemos analisar o processo de desenvolvimento da atividade agroindustrial canavieira no município de Santa Rosa de Viterbo, tendo como apoio a Usina Amália, com o intuito de demonstrar a grande imbricação existente entre as atividades canavieiras e a história da cidade e do campo, monopolizadas pela monocultura da cana-de-açúcar e pelo poder em múltiplas escalas de seus proprietários: as Indústrias Reunidas F. Matarazzo.

Desde este trabalho, a escolha da usina como tema de estudo se deve ao fato de o pesquisador ter maior afinidade por esta região, por ter nascido e morado em Santa Rosa de Viterbo. Dessa forma, a trajetória do pesquisador teve uma importância grande na escolha do tema de estudo, visto que esta realidade faz parte da sua própria história de vida, ou seja, revela sua pertença a esse ambiente social.

Esse fato ainda alentava uma indagação persistente desde a defesa do TGI: como se desenvolveu o processo de territorialização da agroindústria canavieira após o anúncio da concordata da Agro Industrial Amália S.A. e da decadência do grupo Matarazzo na Fazenda Amália ?

Tal proposta exigia levar em consideração uma outra territorialidade, uma relação assentada não apenas nas conexões da agroindústria canavieira com o município que abrigava sua sede - Santa Rosa de Viterbo - como havia sido feito na pesquisa anterior, mas o envolvimento de toda a propriedade denominada Fazenda Amália, que englobava terras pertencentes aos atuais municípios de Cajuru, Santa Cruz da Esperança, Santa Rosa de Viterbo, São Simão, Serra Azul e Tambaú, conforme revela o Mapa 1, na página seguinte. 
Mapa de localização da Fazenda Amália (Mapa 1) 
A primeira dificuldade, e verificada desde a pesquisa anterior, foi a carência de fontes primárias relacionadas à propriedade. Sabe-se que os arquivos da Fazenda Amália e da usina homônima estão sob controle da família Matarazzo, que em decorrência das inumeráveis ações trabalhistas e processos judiciais movidos contra as empresas do grupo familiar, recusam o acesso a esses documentos como fonte para investigações científicas.

O mesmo vale para as representações cartográficas da antiga fazenda. Deparamos no decorrer da pesquisa com importantes mapas e croquis que se reportavam aos domínios de Amália, mas que igualmente não foram concedidas ao pesquisador ${ }^{1}$.

Mediante esses desafios procuramos revertê-los em parte recorrendo-se aos depoimentos orais. Mas aí outra questão estava à vista: como selecionar os sujeitos e as técnicas de pesquisa empregadas, visto que parte significativa da população de Santa Rosa de Viterbo e municípios vizinhos apresentam uma relação íntima com a história da Fazenda Amália? E a base espacial dessas entrevistas?

Trata-se de propostas que, no nosso ponto de vista, são muito amplas e bastante audaciosas para este trabalho, para as quais são, sem dúvida, necessários levantamentos de dados, informações e reflexões que demandariam uma vida inteira. Mas é preciso começar...

Dessa forma, limitamos o universo de nossos depoentes aos trabalhadores e ex-trabalhadores canavieiros da Fazenda Amália - ex-colonos e assalariados rurais, ligados diretamente à produção ou à gestão do trabalho na lavoura canavieira -, residentes na cidade de Santa Rosa de Viterbo, com a

\footnotetext{
${ }^{1}$ Trata-se de vários mapas topográficos demarcados com a dimensão territorial da Fazenda Amália disponíveis no escritório da Usina Santa Rita na antiga Fazenda Amália (Fazenda Boa Vista, município de São Simão). Esses mapas foram visualizados pelo pesquisador em pesquisa de campo realizada, junto ao escritório da Fazenda Boa Vista, em setembro de 2006. Foi feito um pedido de autorização de acesso às fontes cartográficas ao escritório central da Usina Santa Rita, encaminhamento que foi negado pela sua gerência, em Santa Rita do Passa Quatro, mesmo depois de vários telefonemas e esclarecimentos sobre o trabalho por parte do investigador.
} 
preocupação de obtermos registros orais que contribuiriam qualitativamente para análise dos processos sócio-espaciais abarcados nesta pesquisa.

Foi fundamental o apoio dado pelos dirigentes do Sindicato dos Trabalhadores Rurais de Santa Rosa de Viterbo, sugerindo possíveis entrevistados para este estudo.

Pudemos nos deter um pouco mais nas relações de trabalho nos canaviais da Fazenda Amália, inquietação que já havia aparecido no trabalho anterior e que agora poderia ser melhor discutida.

Essa fase da pesquisa estendeu-se, sobretudo, durante todo o ano de 2005 e envolveu a coleta de depoimentos orais de trabalhadores (as) e extrabalhadores (as) rurais canavieiros (as), residentes na cidade de Santa Rosa de Viterbo, que se ocuparam em diferentes momentos históricos da produção canavieira na Fazenda Amália.

Num primeiro momento, centramo-nos no recolhimento de testemunhos orais de alguns ex-colonos (as) e assalariados rurais que laboraram na fazenda dos Matarazzo, até o início dos anos 1990.

Em seguida, apoiamo-nos nas declarações manifestas de homens e mulheres empregados nas lides dos canaviais desde 1990, período que sucede o conhecimento público da segunda concordata de empresas do grupo Matarazzo, dentre elas a Agro Industrial Amália S.A².

As entrevistas envolveram catorze trabalhadores(as) e extrabalhadores(as) rurais de diferentes fases de administração da usina sediada no município de Santa Rosa de Viterbo, além daqueles que trabalham nas terras que a Usina Santa Rita adquiriu da Fazenda Amália.

São ex-colonos ou descendentes de colonos (três depoentes: dois homens e uma mulher) e canavieiros que trabalharam na Usina Amália até meados da década de 1980 (dois depoentes: um homem e uma mulher), no

${ }^{2}$ Cf. AMÁLIA pede concordata. O Santa Rosa, Santa Rosa de Viterbo, ano 1, n 23 , p. 1, 24 dez. 1990. 
início da década de 1990 (quatro depoentes: um homem e três mulheres), durante o período e que a usina foi arrendada pelo grupo Cury (dois depoentes: um homem e uma mulher), que trabalham hoje em terras da Usina Santa Rita na antiga Fazenda Amália (três depoentes: três homens) ou nas terras arrendadas da mesma pela Usina Da Pedra (um depoente, um homem).

Longe da pretensão de buscar uma amostra significativa dos trabalhadores(as) e ex-trabalhadores(as) de Amália, pudemos comprovar por meio das falas dos depoentes muitos elementos revelados pelos trabalhos examinados sobre a área estudada e, desse modo, procurar sanar a dificuldade de dados decorrentes da negação do acesso à consulta das fontes primárias.

As técnicas de pesquisa empregadas foram a história de vida, entrevistas semidirigidas e relatos orais.

A história de vida abarcou principalmente os ex-colonos da Fazenda Amália, sendo que, por meio de suas falas, pudemos minimamente apreender as condições de vida e trabalho desses homens e mulheres alojados nas colônias de trabalhadores rurais dos Matarazzo, sujeitos sociais que foram o alvo das investigações de Silva (1999, 2001,2006), trabalhos fundamentais para a interpretação da transição do colonato para o assalariamento no nordeste paulista.

As entrevistas semidirigidas abrangeram principalmente os assalariados rurais ex-canavieiros que trabalham ou trabalharam em Amália, no período em que a produção canavieira foi controlada diretamente pelo grupo Matarazzo, ou indiretamente, por meio de arrendamento da usina e de parte das terras da antiga fazenda pelo grupo Cury e Irmãos Biagi S.A. ${ }^{3}$. A escolha deu-se, sobretudo, em razão das limitações do roteiro de questões formuladas pelo pesquisador e das relações de pesquisa estabelecidas entre entrevistador-

\footnotetext{
${ }^{3}$ Desde abril de 2007 a denominação social do grupo Irmãos Biagi S. A foi alterada para Pedra Agroindustrial S. A (Disponível em: <www.unica.com.br> Acesso em 21 jun. 2007
} 
entrevistado, trazendo à luz informações valiosas que enriqueceram a investigação.

Já os relatos orais se estenderam a funcionários administrativos das usinas Ibirá (engenheiro químico e técnico agrícola) e Santa Rita (responsável pelo escritório da Fazenda Boa Vista) e da empresa Canamor (gerente administrativo), a partir dos quais e pretendíamos levantar informações acerca da produção e do trabalho na agroindústria canavieira - no caso das Usinas Ibirá e Santa Rita - e dados pertinentes à organização fundiária e dos contratos de arrendamento após 1990 na sede social da empresa Canamor Agroindustrial e Mercantil S.A., na antiga colônia-sede da Fazenda Amália.

No que se reporta à Usina Ibirá, o contato do pesquisador com a gerência da usina se deu logo após a passagem pelo exame de qualificação. Encorajado pelas inquirições da banca, apresentamo-nos ao escritório da empresa, no qual fomos recebidos pela gerência industrial e agrícola da mesma. O primeiro contato efetivou-se por meio do engenheiro químico da usina, respondendo às questões do pesquisador e informando dados referentes às relações de produção e de trabalho na parte industrial, comunicação que se estendeu por mais dois encontros. Num deles, foi realizada uma visita técnica à parte industrial, bem como foram fornecidas algumas fotografias sobre o interior da usina. A relação com a gerência agrícola se deu por meio do técnico agrícola, respondendo a questões pertinentes à organização do trabalho e da produção na lavoura canavieira.

Já no que se refere à Usina Santa Rita, as relações se desenvolveram por meio do escritório da empresa, na Fazenda Amália, situado na antiga seção Boa Vista (no lugar outrora ocupado pela colônia de mesmo nome, a antiga $5^{\mathrm{a}}$. Seção da fazenda Amália, no município de São Simão). A responsável pelo escritório local encaminhou o ofício do pesquisador, solicitando o levantamento de dados para a realização da pesquisa, pedido que foi negado pelo setor de recursos humanos da Usina Santa Rita, o mesmo ocorrendo em outros departamentos da mesma por meio do contato direto do pesquisador. 
Também tivemos a oportunidade de entrar em contato com a empresa Canamor Agro-Industrial e Mercantil e conversarmos com seu gerente administrativo. A conversa foi rápida, mas fundamental, esclarecendo vários pontos relacionados à organização administrativa e fundiária da Usina Amália após o declínio das S.A. Indústrias Reunidas F. Matarazzo nos negócios sucroalcooleiros. Tais informações serviram de subsídio e foram corroboradas com a investigação nos cartórios de registros de imóveis das comarcas que possuíam terras da fazenda.

Foram analisadas 54 certidões de matrículas de imóveis obtidas junto aos cartórios de registro de imóveis de Cajuru (25 matrículas, 19 referentes ao município de Cajuru e 6 ao município de Santa Cruz da Esperança, pertencente à mesma comarca), Cravinhos (3, relativas ao município de Serra Azul), Santa Rosa de Viterbo (8), São Simão (17) e Tambaú (1). Baseando-se no exame das mesmas foi possível compor a organização fundiária da Fazenda Amália, fracionada pelas dívidas contraídas pelo grupo Matarazzo, sobretudo no final das décadas de 1970 e no decorrer da seguinte.

Informações adicionais sobre o processo de trabalho nas diversas fases da lavoura canavieira foram obtidas junto aos representantes do Sindicato dos Trabalhadores Rurais de Santa Rosa de Viterbo por meio de relatos orais colhidos na sede da entidade ou conversas informais nas idas ao local de trabalho nos canaviais e registradas em caderno de campo.

Por meio da documentação fotográfica pudemos ter uma apreensão e descrição de elementos constitutivos do processo de trabalho nos canaviais. Na pesquisa de campo, foram feitos registros pelo autor no local de labor dos trabalhadores canavieiros (20 de março de 2006, 3 de agosto de 2006 e 26 de setembro de 2006). Esses registros foram associados a observações diretas de campo e informações junto ao fiscal da turma e conversas rápidas com os trabalhadores rurais (nas fases de plantio e colheita da cana-de-açúcar) durante o período de almoço ou descanso dos mesmos nos talhões da gramínea. 
Outros registros foram obtidos junto ao Sindicato dos Trabalhadores Rurais, já mencionado, à Fundação Cultural de Santa Rosa de Viterbo e ao escritório da Usina Ibirá.

Nesses locais, as fotografias foram descritas e interpretadas pela mediação dos sujeitos responsáveis (Edna Clemente, ex-presidente do Sindicato dos Trabalhadores Rurais de Santa Rosa de Viterbo e o engenheiro químico da Usina Ibirá).

Outrossim, foram importantes as fotografias aéreas oblíquas de 1939/1940, obtidas junto ao Instituto Geográfico e Cartográfico (pesquisa de campo em setembro de 2006), e figuras oriundas de publicações associadas ao estudo do grupo Matarazzo, dentre elas a obra encomendada pela família para a comemoração do centenário das atividades comerciais da mesma no Brasil, publicada em 1982, sob o título "Matarazzo 100 Anos", e os livros de autoria do jornalista santa-rosense Romeu Antunes, "Histórias de Santa Rosa de Viterbo" (2000) e "Pedras Fundamentais de Santa Rosa de Viterbo" (2006). Trata-se de referências bibliográficas importantes para se compreender as múltiplas faces da história municipal, na qual a Fazenda Amália participa ativamente. Consultas a sítios ${ }^{4}$ forneceram imagens que até então não tinham sido autorizadas ao pesquisador por parte de instituições ligadas à fazenda, como fotografias da antiga colônia-sede da fazenda Amália, hoje controlada pela empresa Canamor, proprietária da usina e de boa parte das terras que formavam a Fazenda Amália.

Quanto à busca de dados, relativos à produção sucroalcooleira do Brasil e do estado de São Paulo, foram essenciais os levantamentos feitos nos Anuários Açucareiros do Instituto do Açúcar e do Álcool e os dados disponíveis no sítio da Unica (União da Agroindústria Canavieira do Estado de São Paulo) e do periódico bimestral da associação intitulado "Informação

\footnotetext{
${ }^{4}$ Os sítios consultados foram: < www.estacoesferroviarias.com.br $>$ e $<$ www.santaro sa.sp.gov.br>, acessados em 21 de abril de 2007.
} 
Unica”, contendo os indicadores relativos a várias safras de cana da região Centro-sul, no qual foi possível precisar as conexões entre as usinas referidas neste trabalho e a produção canavieira e sucroalcooleira estadual e nacional, bem como no interior das empresas que compõem o grupo Pedra Agroindustrial S.A., no nordeste paulista.

A partir dessas considerações que tangem à metodologia de pesquisa, é possível ressaltar agora alguns pontos cruciais deste trabalho.

Iniciamos o nosso estudo a partir da consideração de que a dinâmica da relação sociedade-espaço-tempo é mediada por relações de poder, o que nos levou a buscar no conceito de território o nosso ponto de partida.

Compartilhamos, nesse ponto de vista, com as proposições de Raffestin (1993) de uma dimensão política, para além de uma perspectiva jurídica e estatal como aquela que melhor responde pela conceituação de território.

Desse modo, o território é interpretado como o espaço do político, portanto dotado de possibilidades de transformações e mudanças, cuja efetivação dependerá das forças dos sujeitos sociais empenhados nesta ação. Com isto, o território é marcado por lutas e contradições que se processam no interior da sociedade: a ordem e a mudança, dominadores e dominados, o arcaico e o moderno.

Portanto o território é dinâmico, flexível, aberto, em permanente construção/ reconstrução/ pelos sujeitos sociais, em suas disputas pela sua apropriação. Essa perspectiva teórica, enfatizando uma dimensão política do conceito de território, permite compreendermos o conceito de territorialização, como o processo de materialização no espaço, das relações sociais de produção, produtos do sistema tridimensional sociedade-espaço-tempo. Isso não significa delimitar a dimensão política ao papel do Estado, muito menos desconhecer a intersecção com as dimensões econômica e cultural da sociedade.

É dentro deste quadro teórico que pretendemos alicerçar o desenvolvimento desta pesquisa, sobretudo a partir do entendimento do 
processo de territorialização do capital monopolista na agricultura brasileira. Nesse caso:

[...] quando o capital se territorializa, ele varre do mapa os trabalhadores, concentrando-os nas cidades, quer para ser trabalhadores da indústria, comércio ou serviços, quer para ser trabalhadores assalariados no campo ("bóias-frias"). Neste caso o processo especificamente capitalista se instala e a reprodução ampliada do capital desenvolve-se em sua plenitude. O capitalista/proprietário da terra acumula simultaneamente o lucro da atividade industrial e agrícola (da cultura da cana, por exemplo) e a renda da terra gerada por essa atividade. A monocultura se implanta e define e caracteriza o campo, transformando a terra num "mar" de cana, de soja, de laranja, de pastagem etc. (OLIVEIRA, 1996, p. 478).

Produção e apropriação visível por meio da monocultura canavieira, mas que também gera, revitaliza, reproduz múltiplas relações que expressam no invisível, num processo imaterial que também marca o processo de produção e apropriação do território, em nosso caso, por parte do capital agroindustrial sucroalcooleiro.

A concepção de território, focada numa dimensão política, de modo algum engessa uma leitura redutora do mundo, à que tal dimensão extrapola uma concepção absoluta de poder, tendo em vista que este se espraia para outras esferas, como já foi discutido.

O capital sucroalcooleiro, ao territorializar-se, sob determinadas formas, em determinados momentos históricos, irradia, territorializa também mecanismos de exploração-dominação no espaço físico e social e também numa dimensão simbólica dos sujeitos sociais, impondo sua lógica, os seus poderes que se estendem para múltiplas escalas (que transcendem o nosso recorte territorial, se espacializando também para outras escalas: as escalas que envolvem, por exemplo, o espaço de morada dos trabalhadores migrantes em suas regiões de origem, a escala da articulação política em torno de seus interesses na esfera política no parlamento ou em torno de seu lobby etc), mas 
envolve também a territorialização de um contra-poder ${ }^{5}$, da nutrição de múltiplas possibilidades de pensar e reproduzir a resistência por parte daqueles sujeitos sociais atingidos pelo processo de territorialização do capital.

Como foi ressaltado anteriormente, o território não é um conceito fechado, delimitado e absoluto, mas determinado pelos processos históricos, portanto flexível, aberto, em permanente construção, prenhe de lutas e de contradições e disputas pelos sujeitos sociais em ação, empenhados ou não em suas possibilidades de transformação e mudança.

Pretendemos compreender o processo de territorialização do capital sucroalcooleiro na antiga Fazenda Amália a partir do entendimento do desenvolvimento capitalista da agricultura brasileira, processo imanente à expansão do capitalismo no país.

Movimento que se deu de forma desigual e combinada, permitindo a materialização no território de relações tipicamente capitalistas de produção, mas simultaneamente a produção de relações não capitalistas de produção, promovendo uma reintegração de uma série de elementos que o próprio desenvolvimento do capitalismo tentou apartar, como as múltiplas relações estabelecidas entre cidade e campo, agricultura e indústria etc (OLIVEIRA, 1997, p.79).

Nesse mesmo sentido, o entendimento do desenvolvimento capitalista na agricultura brasileira precisa levar em consideração a mundialização do capital e a internacionalização da economia brasileira. Estes processos ocasionaram a intensificação da ação de grandes grupos econômicos tanto nacionais quanto internacionais à possibilidade histórica da apropriação da renda capitalista da terra por grandes proprietários de terra e aos capitalistas/ proprietários de terra, provocando uma intensificação na estrutura fundiária brasileira, conforme suscita as reflexões de Oliveira (1996, p. 468).

Thomaz Jr.(1988), ao analisar a dinâmica das agroindústrias canavieiras nas imediações do município de Jaboticabal no final da década de 1980,

\footnotetext{
${ }^{5}$ Contra-poder pensado segundo a interpretação de Silva (1999, p. 241).
} 
utiliza-se do conceito de territorialização do monopólio da atividade canavieira, ao entender que, naquele caso, não havia separação, por parte do capital, entre capitalista e proprietário rural, havia, portanto uma apropriação da renda fundiária pelo capital, já que este era também responsável pela maior parte da matéria-prima consumida no processo produtivo.

O autor analisa esse processo por meio de uma territorialização da monopolização da renda fundiária, já que é o grupo monopolista que se apropria do lucro e da renda da terra (1988, p. 220).

Dessa forma, essas reflexões são cabíveis para a compreensão do processo de territorialização do capital canavieiro, comandado pela Usina Amália, a partir da produção da maior parte da cana-de-açúcar a ser processada na unidade industrial na Fazenda Amália, ou seja, em terras próprias. Esse mecanismo era favorável às usinas, já que as mesmas exerciam o controle sobre a maior parte da produção da cana, o qual se estendia à circulação de seus principais subprodutos, o açúcar e o álcool. Tal controle foi abrandado pela entidade estatal que regulava a atividade do setor: o Instituto do Açúcar e do Álcool (IAA).

Ao territorializar o controle econômico exercido pelas agroindústrias nesse espaço circunscrito, Thomaz Júnior propõe um roteiro jurídicoeconômico do processo de territorialização do monopólio, procedimento que permitiu conhecer a origem do agricultor, do proprietário que vendeu suas terras ao grupo usineiro.

Em nossa área de estudo, sabe-se que a Fazenda Amália chegou a ter uma dimensão de onze mil alqueires de terras (MATARAZZO 100 ANOS. São Paulo: sd., p. 82) que abrangiam quatro municípios do nordeste paulista (Santa Rosa de Viterbo, São Simão, Serra Azul, Tambaú e Cajuru, além do atual município de Santa Cruz da Esperança, desmembrado de Cajuru em 1993), especializando-se na cultura da gramínea. Dessa forma, a usina plantava, colhia, transportava e processava a cana-de-açúcar, matéria-prima 
para a produção do açúcar e do álcool, nos moldes apresentados por THOMAZ Jr. anteriormente.

As reflexões de Thomaz Jr (1988) nos ajudam a ler a manifestação territorial desse processo, num momento determinado, estendido, de modo geral, à compreensão da dinâmica territorial da agroindústria canavieira paulista, sobretudo nas principais áreas produtoras da gramínea, contexto também marcado por uma forte intervenção estatal no setor, representado pelo IAA e pelos últimos momentos de euforia vividos pelo Programa Nacional do Álcool no final da década de 1980.

No entanto, uma nova dinâmica vai se desenvolver na década seguinte, a partir do anúncio do pedido de concordata em série de várias empresas do grupo Matarazzo, inclusive da Usina Amália.

Por meio de uma medida provisória baixada pelo governo federal, em dezembro de 1990, o grupo econômico proprietário da usina e da Fazenda evitou a falência de várias de suas empresas.

Tal caminho permitiu que a unidade industrial e as terras pertencentes ao grupo familiar fossem arrendadas a um outro grupo usineiro do nordeste paulista, sendo que parte das terras foram tomadas pelos credores, como pagamento de débitos.. Este processo provocou uma alteração na conformação fundiária da então Fazenda Amália - controlada pela família Matarazzo e ocupada produtivamente com plantações de cana-de-açúcar.

Assim, para compreendermos a organização da agroindústria canavieira durante a década de 1990 por meio de novas formas de gestão do capital, por uma outra conjuntura setorial e arranjos nas relações de trabalho, ou seja, a reestruturação das relações de produção e trabalho no interior da agroindústria canavieira em nossa área de estudo, não precisamos abandonar o conceito de territorialização do monopólio refletida por Thomas Jr. (1988) em suas pesquisas no final da década de 1980.

Pensamos que o emprego do conceito de territorialização do monopólio ainda é valido, visto que a “construção do monopólio agroindustrial assegura 
ao capital um extraordinário poder político e econômico”, processo que se mantém hoje com “novas roupagens”, ou nas palavras de Antunes (1999, p. 31) como um "processo de reorganização do capital e de seu sistema ideológico e político de dominação”. Para corroborar essa idéia, assim nos diz Thomaz Jr (2002, p. 200):

Com a materialização do processo específico de internalização do "progresso técnico", processa-se outro salto qualitativo em direção ao (novo) eixo da acumulação do capital. Apesar de não inviabilizar o anterior, ao contrário, o redimensiona, com o propósito de superar a relação centrada na transferência da mais-valia, na forma de renda da terra (com a territorialização do monopólio), sinalizando, agora, para a hegemonia na apropriação da mais valia relativa e para a subsunção real do trabalho ao capital.

$\mathrm{Na}$ verdade, tratava-se de uma nova roupagem para a continuidade do processo de reprodução do capital e territorialização do poder econômico, político e social das agroindústrias canavieiras.

Propomos a análise do processo de territorialização da agroindústria canavieira no nordeste paulista, tendo como base uma das mais antigas processadoras de açúcar e álcool do país, dominada ao longo de sua centenária história por grandes proprietários de terra que, também, se tornaram empresários, atuando em outras atividades econômicas, lógica esta que se altera com o anúncio de concordata por parte do grupo Matarazzo, até então proprietário da mesma, e o processo de reestruturação produtiva nas parcelas da propriedade e da usina, acompanhando a conjuntura do setor, mas que traz elementos novos: a produção sucroalcooleira não é realizada pelo proprietário da usina e da maior parte das terras, como num momento anterior (até meados da década de 1980 e início da seguinte), abstendo-se da fase produtiva, auferindo única e exclusivamente a renda da terra e mantendo intocada a 
concentração fundiária, de uma nova forma, na qual se incorpora outros elementos, inseridos na reprodução do capital sucroalcooleiro.

A fragmentação da Fazenda Amália, em várias propriedades, pertencentes a diferentes sujeitos sociais e empresas, não diminuiu a concentração fundiária, prova disso é que importantes frações da fazenda se constituem hoje, como no passado, nas maiores propriedades rurais dos municípios em que se localizam, prova cabal de que a centralização fundiária se ancora agora em outras bases, por outras formas de controle, diferente de fases anteriores em que toda a fazenda Amália era da família Dumont, e, depois, da família Matarazzo. E hoje, quem são os donos de Amália? Que processos comandam hoje a territorialização canavieira na antiga fazenda?

Foi importante reconstituir uma base histórica de toda a propriedade e para a qual reportamo-nos às origens de sua formação, na última década do século XIX, com Henrique Santos Dumont. Assim, iremos explicitar porque a territorialização do capital açucareiro e depois também alcooleiro se faz desde os tempos do grande fazendeiro e empresário paulista. A fazenda Amália sempre assentou a sua produção canavieira e sucroalcooleira a partir da produção própria da maior parte da matéria-prima esmagada em suas moendas, com os Dumont, depois com a família Matarazzo. E mais, sempre se destacou ao longo de sua história por uma grande produção de cana, açúcar e álcool em termos estadual e nacional por meio de diferentes relações de trabalho, primeiramente apoiada no colonato, herança dos tempos do café, depois ancoradas no trabalhador volante, produto de um violento processo de expropriação e expulsão, legitimadas segundo a "lei e a ordem", mas igualmente desagregadora, com marcas no território construído pelo capital e também dolorosas lembranças e lacunas nos “órfãos de Amália”. São esses os principais pontos que discutiremos no Capítulo 1.

No segundo capítulo do trabalho, discutiremos os principais conceitos que nortearam o desenvolvimento desta pesquisa, destacando o processo de 
territorialização do capital sucroalcooleiro no viés da "modernização conservadora", materializado na nossa área de estudo, bem como as conseqüências do processo de proletarização em suas múltiplas dimensões na produção do agrário e do urbano, sobretudo no município de Santa Rosa de Viterbo.

Num terceiro capítulo, discorreremos sobre o processo de reestruturação produtiva da lavoura canavieira na área que compõe a antiga Fazenda Amália, hoje controlada pelas Usinas Ibirá (administrada pela Usina Da Pedra) e Santa Rita- dois importantes grupos usineiros do nordeste paulista - para, posteriormente, particularizarmos as implicações sociais para o conjunto dos trabalhadores da lavoura canavieira residentes permanente ou temporariamente no município de Santa Rosa de Viterbo, principalmente no que concerne às relações de trabalho territorializadas nos canaviais de Amália. 
A Fazenda Amália dos Matarazzo: Fides, Honor, Labor 


\subsection{A Formação da Fazenda Amália nos tempos de Dumont}

A Fazenda Amália, unidade territorial desta pesquisa, tem como núcleo a Fazenda Santa Constância, parte da antiga Fazenda Coqueiros, também chamada de Fazendinha ${ }^{1}$,até então propriedade da Empresa Industrial de Melhoramentos do Brasil $^{2}$. (Veja o Mapa 2 na página 20).

Em janeiro de 1894, a gleba de terras denominada Fazenda Santa Constância foi vendida a Henrique Santos Dumont ${ }^{3}$, um dos mais importantes

\footnotetext{
${ }^{1}$ De acordo com Vasconcellos Martins (1998, p. 109-12), a Fazenda Santa Constância constitui-se numa gleba de terras da antiga Fazenda Coqueiros, também conhecida posteriormente pela denominação de Fazendinha. Esta antiga fazenda estendia-se por uma área aproximada de 3.680 hectares, situando-se nas proximidades da atual cidade de Santa Rosa de Viterbo, alcançando a margem esquerda do Rio Pardo. Segundo o mesmo autor, outras partes desta antiga fazenda foram adquiridas por Henrique dos Santos Dumont, tendo como base a divisão judicial das terras da propriedade requerida em fevereiro de 1896. Já Antunes (2000, p. 265-67), reproduzindo o texto intitulado "A formação da Fazenda Amália”, de autoria de Vitorino Falaguasta, confirma a indicação de Vasconcellos Martins (1998) ao mencionar as aquisições de partes da Fazendinha, feitas em agosto de 1894 e em junho de 1907.
}

2 A ex-proprietária da Fazenda Santa Constância, a Empresa Industrial de Melhoramentos do Brasil tornou-se, em 1891, acionista majoritária da Companhia Agrícola Fazenda Dumont, criada, por Henrique Dumont (pai de Henrique Santos Dumont), em 1880. A fazenda de Henrique Dumont possuía aproximadamente seis mil alqueires, situados nos então municípios de Ribeirão Preto e Sertãozinho (BRAY, 1989, p.129), na penúltima década do século XIX. Baseado no Diário Oficial de São Paulo, de 7 de abril de 1892, Zamboni (1979, p.21) indica que "das 42.500 ações da Companhia Agrícola Fazenda Dumont, 41.375 pertenciam a Empresa Industrial Melhoramentos do Brasil, e as restantes 1.125 estavam distribuídas entre os vários Dumont, Villares e Paulo de Frontim”.

${ }^{3}$ Henrique Santos Dumont (1857- 1920) era o primogênito do matrimônio de Henrique Dumont, mineiro de Diamantina e da também mineira Francisca de Paula Santos. Foi filho do primeiro grande fazendeiro de café das terras férteis da região de Ribeirão Preto e também pioneiro na expansão dos trilhos e no emprego de colonos imigrantes em suas propriedades de café no nordeste paulista. Seu pai foi, segundo Zamboni (1979, 13 - 4), o maior comprador de terras na penúltima década do século XIX, na área cafeeira de Ribeirão Preto. Henrique Dumont fora também afetado por um grave acidente de charrete, tornando-se hemiplégico, falecendo em agosto de 1892. Em decorrência disso, resolveu dividir a herança entre os oito filhos. A parte que coube ao filho mais velho, este decidiu aplicar na compra de terras, e cujo resultado foi a compra da Fazenda Santa Constância, em janeiro de 1894. Do irmão do meio de Henrique Santos Dumont veio 
fazendeiros de café paulista do último quartel do século XIX e das décadas iniciais do século XX, por 146 contos de reis (BRAY, 1989, p. 130). Parte considerável do patrimônio de Henrique Santos Dumont foi edificada com parte da herança familiar que contava, desde 1892, por ocasião da partilha do patrimônio familiar, em decorrência de um grave acidente com seu pai (ANTUNES, 2006, p.22).

À Fazenda Santa Constância, adquirida em 1894 no município de São Simão, foram acrescidas outras glebas de terra compradas por Dumont, aquisições estas que podem ser divididas em dois períodos: o primeiro que vai de 1894 a 1898; e o segundo, estendendo-se de 1907 a 1919(BRAY, 1986, p.43- 4).

Este rápido processo de expansão fundiária até 1897 é sucedido com os trabalhos de derrubada da vegetação e plantação de café e também de cana-deaçúcar nas propriedades Constança, Peroba e Coqueiros (BRAY, 1989, p.130). Os primeiros cultivos da gramínea foram organizados por meio do trabalho de empreita de três irmãos (ANTUNES, 2000, p.266).

A iniciativa do fazendeiro Henrique dos Santos Dumont de produzir canade-açúcar na maior área produtora de café do país e, ainda mais por um de seus maiores representantes, foi tema das reflexões do geógrafo Silvio Carlos Bray (1989) no que concerne à transferência de capitais da atividade cafeeira para outras atividades econômicas e da dinâmica da atividade açucareira no estado de São Paulo até a década de 1940.

parte importante dos recursos que hoje o consagram como o "pai da aviação"(ANTUNES, 2006, p. 21-2). Henrique Santos Dumont casou-se com Amália Ferreira (daí o nome dado posteriormente a sua propriedade, em homenagem à esposa), com a qual teve três filhas (ANTUNES, 2000, p. 266). Foi um dos empresários mais ricos desse país, no início do século passado, possuindo residência fixa em São Paulo, na Alameda Cleveland, sendo que raramente dirigia-se a sua propriedade inicialmente denominada Fazenda London, depois Fazenda Amália. 
Mapa 2 


\begin{abstract}
Nesse sentido, estamos procurando demonstrar que o avanço da cultura canavieira paulista não dependeu apenas das crises sucessivas do café, mas sim e principalmente pelo deslocamento contínuo dos lucros dos cafeicultores para os negócios da industrialização do açúcar. (BRAY, 1989, p. 127).
\end{abstract}

Bray faz uma análise das pesquisas, segundo as quais as crises sucessivas do café dos fins do século XIX e nas décadas iniciais do século XX, geraram o desenvolvimento e a formação do capital que provocou a expansão da agroindústria açucareira em São Paulo (BRAY, 1989, p. 1). Para Bray (1989, p. 3- 4) “ao mesmo tempo, quanto mais os cafezais se expandiram em São Paulo, mais prosperava a lavoura canavieira, as engenhocas e as usinas de açúcar.

As investidas de Henrique Santos Dumont, em sua fazenda sediada no município de São Simão, e de Francisco Schmidt, o maior fazendeiro de café paulista da década de 1890, fornecem, segundo o autor (1989, p.1), elementos importantes para questionarmos a linha interpretativa que orientou a maior parte dos trabalhos sobre a agroindústria açucareira paulista até o final da década de 1980, os quais se apoiavam numa ótica finalista da economia canavieira com o avanço do café no século XIX, tendo seu ressurgimento condicionado pelos momentos de crises sucessivas da rubiácea nos fins do século XIX e nas décadas iniciais do século passado.

Muitos dos grandes plantadores da gramínea, em São Paulo, eram também grandes fazendeiros de café e de outras culturas, como algodão ou fumo, envolvidos em outros negócios como a comercialização de diversos produtos e acionistas de ferrovias. As múltiplas atuações dos fazendeiros foram consideradas por Bray ao analisar a constituição de "fazendas mistas”, sobretudo de café e cana-de-açúcar no "quadrilátero do açúcar”, ,constituído no "velho oeste”paulista desde a segunda metade do século XVIII.

4 De acordo com Bray (1989, p.33), o “quadrilátero do açúcar” envolvia a mais importante área produtora de cana-de-açúcar da segunda metade do século XVIII até 
Estamos de acordo com as interpretações de Bray (1989) ao enfatizar essa leitura da coexistência e complementaridade das culturas cafeeira e canavieira durante a segunda metade do século XIX e as primeiras décadas do século seguinte, por meio da existência das ditas "fazendas mistas".

A fazenda de café e cana-de-açúcar de Dumont foi uma das pioneiras na mais pujante área produtora da rubiácea ${ }^{5}$ em São Paulo. Henrique Santos Dumont foi também um dos primeiros usineiros paulistas:

Foi a primeira e a mais importante usina das primeiras décadas do século XX no Planalto Ocidental paulista nas famosas terras roxas da região de Ribeirão Preto. É o típico caso de investimento de grande cafeicultor no processo de formação do capital na agroindústria açucareira paulista (BRAY, 1986, p. 43).

Andrade (1994 p.167-68) discorre sobre a produção açucareira paulista e brasileira até o início das década de 1930:

[...] embora o açúcar tivesse subsistido à expansão cafeeira, ele perdeu a importância como principal atividade econômica e a liderança na economia da província [São Paulo].Os engenhos bangüês se mantiveram, não produzindo para o mercado externo, mas para o atendimento do mercado interno de São Paulo, de Minas Gerais e do Paraná, cujas populações estavam em crescimento. [...] Até 1930, as usinas paulistas foram implantadas por plantadores de cana, donos de engenhos bangüês, e por fazendeiros de café, que deram maior

meados do século XIX, no “oeste antigo" paulista. Era formado por uma figura geométrica em cujos vértices situavam-se Jundiaí, Mogi-Mirim, Piracicaba e Sorocaba.

${ }^{5}$ Como indica Bray (1989, p. 72-75, 101, 110, 116,150 e 159), a usina de Dumont, denominada Usina London, fundada em 1899, foi a nona fábrica de açúcar criada desde a instalação dos engenhos centrais em São Paulo, no último quartel do século XIX. É nos dias de hoje a segunda usina mais antiga em operação no estado de São Paulo, só superada pela Usina Rafard, herdeira do antigo Engenho Central Capivari, inaugurado em 1881, hoje propriedade do grupo COSAN. As demais unidades industriais açucareiras originadas, neste período, foram extintas ou tiveram suas atividades cessadas. 
importância ao açúcar em vista do crescimento da demanda deste produto e dos problemas surgidos com o excesso da produção cafeeira. Na verdade, a grande produção brasileira estava tendo dificuldade de se colocar no mercado mundial, o que levava o governo a desenvolver uma política muito onerosa para preservá-la.

A “fazenda mista" de Dumont constituiu a base territorial e econômica do que vai se constituir, algumas décadas depois, a Fazenda Amália sob a administração do Conde Francisco Matarazzo Júnior.

Já em 1898, cessado o período das primeiras compras de terras nas imediações da gleba Santa Constância, inicia-se, como já fora mencionado, a derrubada da vegetação e o plantio de café e cana-de-açúcar. Antunes (2000, p.73) aponta que Dumont construiu, entre 1898 e 1899, um ramal ferroviário que ligou sua fazenda ao tronco da Companhia Mogiana de Estradas de Ferro, experiência semelhante a que seu pai realizou na Companhia Agrícola Fazenda Dumont, uma década antes(ZAMBONI, 1979, p.14).

Esses ramais secundários foram conhecidos por “cata-café” e eram construídos pelas grandes companhias de estrada de ferro do nordeste paulista (Companhias Mogiana e Paulista) ou por investidores locais; produtores interessados em unir suas propriedades ao serviço ferroviário, dando origem a pequenas companhias locais, sem muitos interesses do que unir seus trilhos à linha principal da Companhia Mogiana ou Paulista. (BACELLAR, 1999, p.122).

Partindo da estação Glória $^{6}$ da E.F. Mogiana (Vide Figura 1), o ramal Dumont $^{7}$ passava pelo povoado de Nhumirim e o distrito de Santa Rosa encerrando os trilhos na sede da fazenda ${ }^{8}$, como mostra a Figura 2.

\footnotetext{
${ }^{6}$ A estação, a partir de 1907 passou a se chamar Santos Dumont, em homenagem ao inventor do avião, irmão do fazendeiro. Foi desativada e substituída, em 1972, por uma nova, bem próxima a ela, com o mesmo nome, que funcionou por muitos anos num vagão adaptado, e que somente em 1986 ganhou novas instalações, quando o prédio da antiga estação ainda existia e servia de depósito para a plantação de eucaliptos da empresa Champion, conforme informações disponíveis no sítio <www.estacoesferrovia rias.com.br>, acessadas em 21 de abril de 2007.
} 


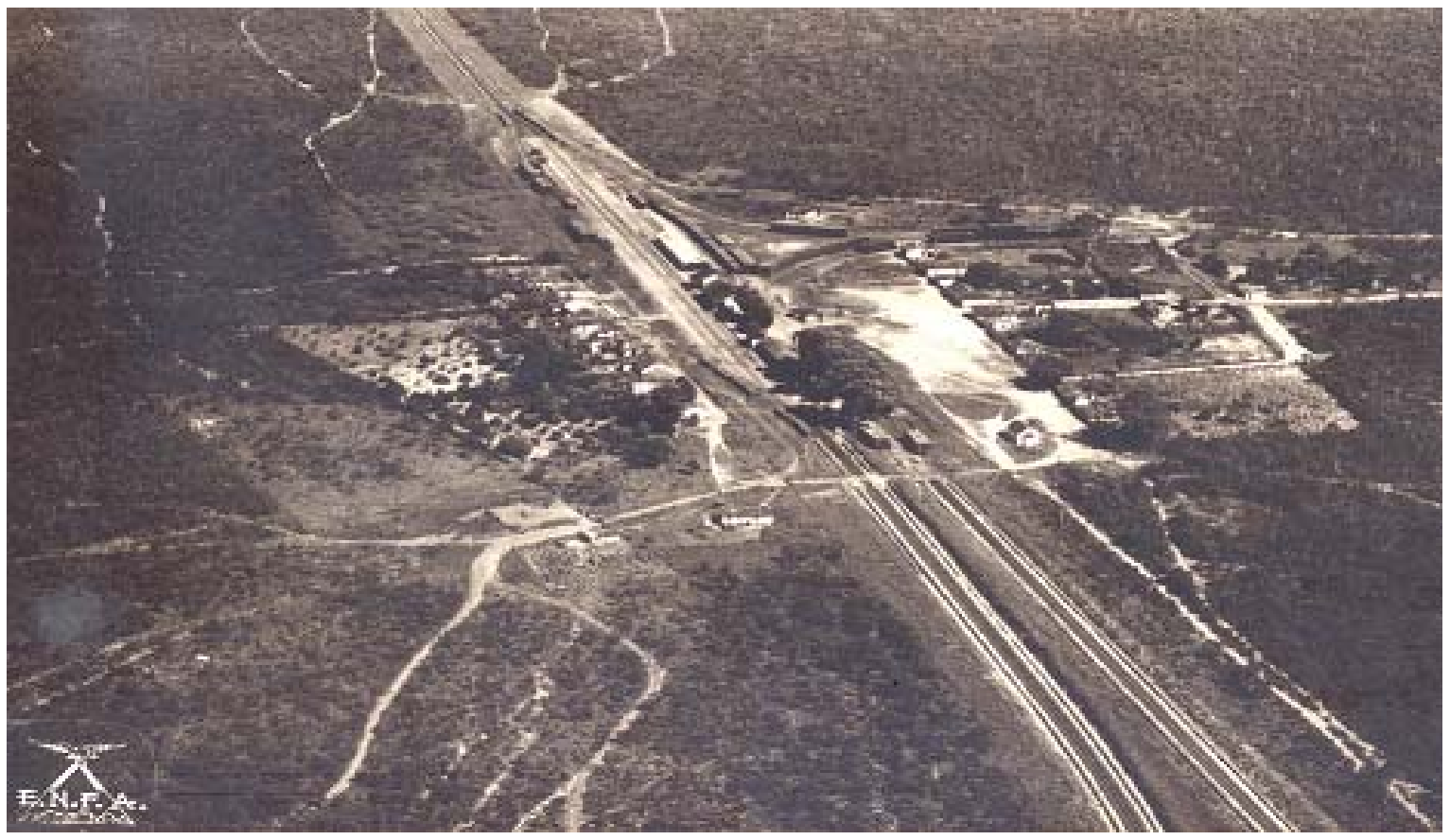

Figura 1 - Estação ferroviária Santos Dumont (antiga estação Glória) Situava-se na porção sul do atual município de Santa Rosa de Viterbo/SP.

Fonte: Arquivo de Fotografias Aéreas Obliquas 1939/1940, do Instituto Geográfico e Cartográfico.

${ }^{7}$ Nome pelo qual ficou conhecido os trilhos dirigidos a fazenda de Henrique Santos Dumont, no município de São Simão (Disponível em < www.estacoesferroviarias.co m.br > Acesso em 21 abr.2007).

${ }^{8}$ De acordo com as informações disponíveis no sítio <www.estacoesferroviarias.com br>,acessadas em 21 de abril de 2007, a estação de Amália teria sido originalmente um posto telegráfico, que foi transformado em estação já sob controle da E. F. Mogiana em 11 de novembro de 1911. Da estação saía a ferrovia particular da Fazenda Amália, com 31quilômetros, dividida em vários sub-ramais, como se pode observar no Mapa 3, da página 45. A partir de 16 de setembro de 1966, a estação ferroviária Amália transformou-se na ponta do Ramal de Cajuru, com a desativação do trecho até esta cidade. Finalmente, com a desativação do que restava do ramal em 3 de janeiro de 1967, a estação foi fechada também. Os ramais particulares da fazenda ainda mantiveram o trecho, que prosseguiu funcionando como desvio particular da fazenda por mais alguns anos, porém sem tráfego dos trens de passageiros da Companhia Mogiana. 


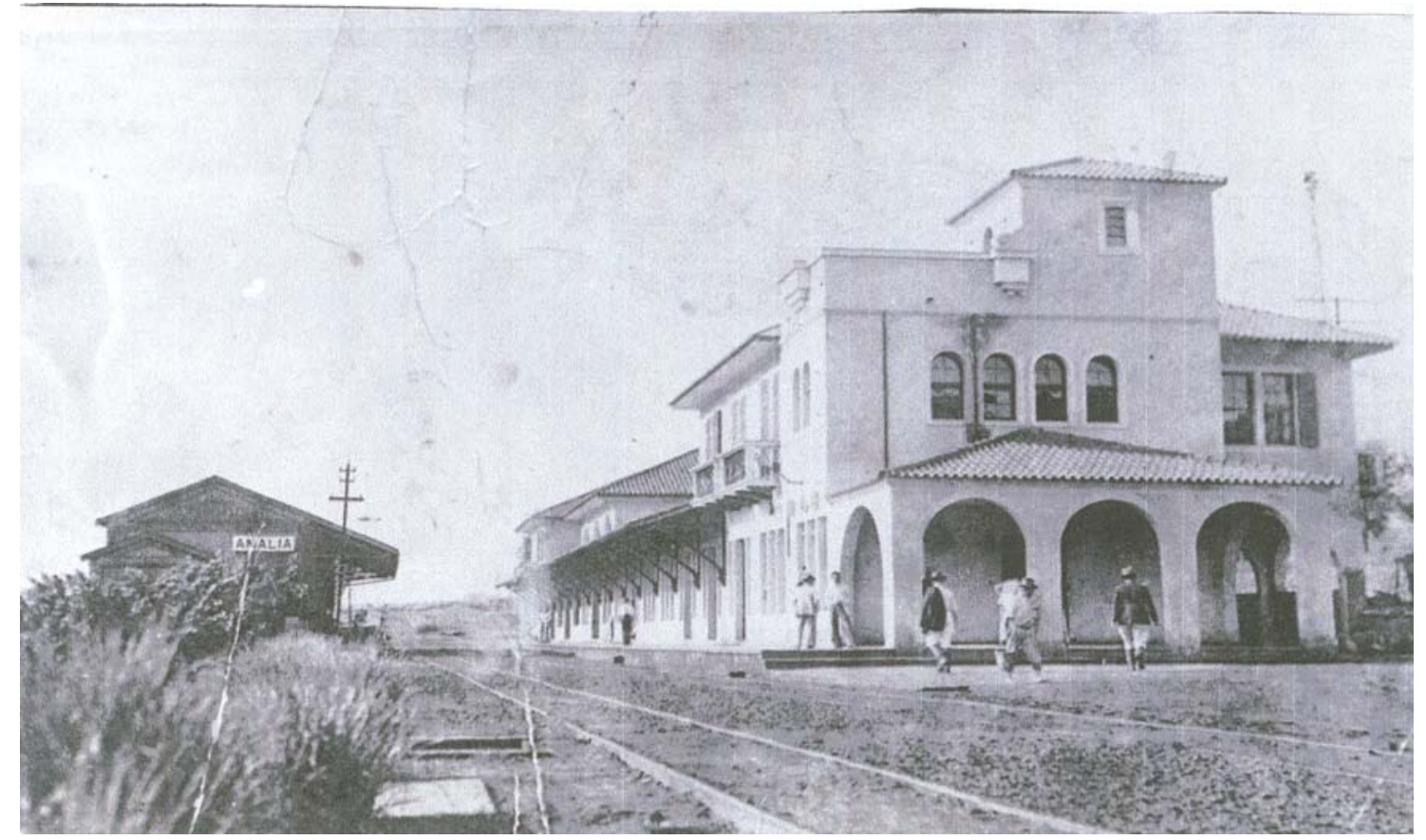

Figura 2 - Estação Ferroviária de Amália. Fotografia sem data. Fonte: Fundação Cultural de Santa Rosa de Viterbo.

O ramal da fazenda permitia o escoamento da produção pelo mais importante e eficiente meio de transporte de mercadorias deste período, além de possibilitar uma articulação com outras escalas econômicas e o deslocamento da matéria-prima dos canaviais à usina, até praticamente meados da década de 1950, com as mudanças técnicas ocorridas no sistema produtivo na lavoura e no uso crescente de tratores e caminhões, como discutiremos mais adiante.

Por meio da estrada de ferro veio a maior parte dos trabalhadores da fazenda de café e cana de Dumont. Eram de imigrantes, sobretudo de origem italiana, a maioria desses trabalhadores, que se ocupavam nas lides agrícolas e que se abrigavam em colônias dispersas pela grande fazenda.

De certo modo, a fazenda de Dumont também forneceu a base daquela que se configurou como principal relação de trabalho nas terras do Conde Francisco Matarazzo Júnior até o final dos anos 1960: o colonato. Os “colonos da cana” constituíam a força de trabalho predominante nas unidades de produção de 
açúcar e álcool nesse estado, neste período, como revelam Andrade (1994, p. 205-6) e Perez (2000).

Alguns desses imigrantes também se converteram em administradores, técnicos, diretores e gerentes da usina e da fazenda após a aquisição definitiva da mesma pelas Indústrias Reunidas F. Matarazzo, no início da década de 1930.

Dentre eles, destaca-se Guido Maestrello ${ }^{9}$ que dirigiu, durante muito tempo, a fazenda de Henrique Santos Dumont, sendo escolhido posteriormente como o primeiro prefeito do recém criado município de Ibiquara ${ }^{10}$, no final de 1910.

Parte importante desses imigrantes também se dirigiram para a cidade de Santa Rosa, participando ativamente do desenvolvimento do aglomerado urbano $^{11}$.

${ }^{9}$ Guido Maestrello chegou ao país em 1889, com 20 anos de idade e foi o primeiro diretor da Fazenda Amália. Foi também músico e diretor da Banda Dumont, patrocinada pelo patrão, nas duas primeiras décadas do século XX. Seu nome figura entre os responsáveis pelas eleições realizadas na freguesia já em 1906, por procuração da comarca e município de São Simão. Em 1911, elege-se vereador e seus colegas o aclamam o primeiro prefeito do município (ANTUNES, 2000, p. 69). Foi eleito para o executivo local sucessivamente de 1911 a 1924, no entanto, sendo substituído em diversas ocasiões, por João Garcia Duarte e José Mendes Júnior neste período (ANTUNES, 2006, p. 48, 81, 96).

${ }^{10}$ Em 21 de dezembro de 1910, o distrito de Santa Rosa foi elevado à categoria de município com a denominação de Ibiquara, tendo como sede o povoado de Santa Rosa. Dois anos mais tarde o nome do município, Ibiquara, que vem do tupi-guarani e significa "lugar de buraco", foi alterado para Santa Rosa. Isto ocorreu até 30 de novembro de 1944, quando a reforma toponímica também implantada neste ano, proibia a coexistência de municípios com o mesmo nome, já que havia um outro município mais antigo e com a mesma designação no noroeste gaúcho, e a partir daí passou a ser chamada de Icaturama, que quer dizer "lugar de água boa”, em tupi-guarani. Em 24 de dezembro de 1948, seu nome foi substituído pelo atual, ou seja, Santa Rosa de Viterbo (Guia Cultural do Estado de São Paulo, 2003, p. 125).

${ }^{11}$ Uma parte considerável dos imigrantes europeus e seus descendentes passaram a se destacar nas atividades comerciais, na produção doméstica e nas associações culturais do núcleo urbano, como o Grêmio Operário Internacional de Beneficiência, criado em 1907, hoje chamado Grêmio Recreativo de Santa Rosa de Viterbo. Isso também propiciou o crescimento urbano da jovem cidade, dos fundos de vale próximo da Rua do Comércio, um dos primeiros marcos de ocupação do aglomerado em direção à estação 
O processo de emancipação política do distrito de Santa Rosa foi acompanhado pela venda do ramal ferroviário de Dumont à Companhia Mogiana de Estrada de Ferro, em 15 de dezembro de 1909, por 750 contos (ANTUNES, 2000, p. 74).

Já sob o comando da Companhia Mogiana, várias estações ferroviárias passaram a integrar o “antigo ramal de Dumont” como as estações Nhumirim (construída no povoado de mesmo nome, em julho de 1910), Santa Rosa (na cidade homônima, em maio de 1910) e Corredeira (próxima ao desnível altimétrico do Rio Pardo, entre os municípios de Santa Rosa e Cajuru, inaugurada também em maio de 1910) ${ }^{12}$. No ano seguinte, iniciam-se as obras de construção da ponte de ferro sobre o rio Pardo e, em 1912, os trilhos se estendem até a cidade de Cajuru, conformando o "ramal de Cajuru" da E. F. Mogiana. (ANTUNES, 2000, p.74).

Ainda no final do século XIX, Henrique Santos Dumont centralizou a sede de sua fazenda na então Fazenda Bella Vista que adquirira em novembro de 1897 (ANTUNES, 2000, p.265). A casa da antiga fazenda foi utilizada como sede de sua propriedade, o mesmo ocorrendo posteriormente durante a administração Matarazzo até a construção da residência oficial dessa família, o chamado “palacete”, em meados da década de 1920. Posteriormente, a antiga "casa da fazenda” serviu como residência de gerentes da Fazenda Amália, durante a “fase

ferroviária Santa Rosa, construída pela Companhia Mogiana de Estradas de Ferro em maio de 1910 (ANTUNES, 2006, p. 40).

12 Com a estatização das ferrovias, em 1952, a Companhia Mogiana passou a ser administrada pelo governo paulista: "Na década de 1970 foi extinta a linha Cajuru Amália e Amália passou a fazer uso exclusivo do trecho até Santos Dumont" (ANTUNES, 2000, p.75). Posteriormente, com o incremento do transporte rodoviário, na mesma década, a "Estrada de Ferro Amália" foi desativada e os trilhos arrancados, ficando a cidade de Santa Rosa de Viterbo sem o transporte ferroviário (Disponível em $<$ www. estacoesferroviarias.com.br> Acesso em 21 abr. 2007). 
Matarazzo” e é hoje sede social da atual proprietária da usina e de parte importante de suas terras, a Canamor Agroindustrial e Mercantil S.A. ${ }^{13}$.

Henrique Santos Dumont edificou nas proximidades da “casa da fazenda” uma usina de açúcar (Vide Figura 3) e uma destilaria de álcool, além de uma oficina mecânica (MATARAZZO 100 ANOS, s.d., p. 83).

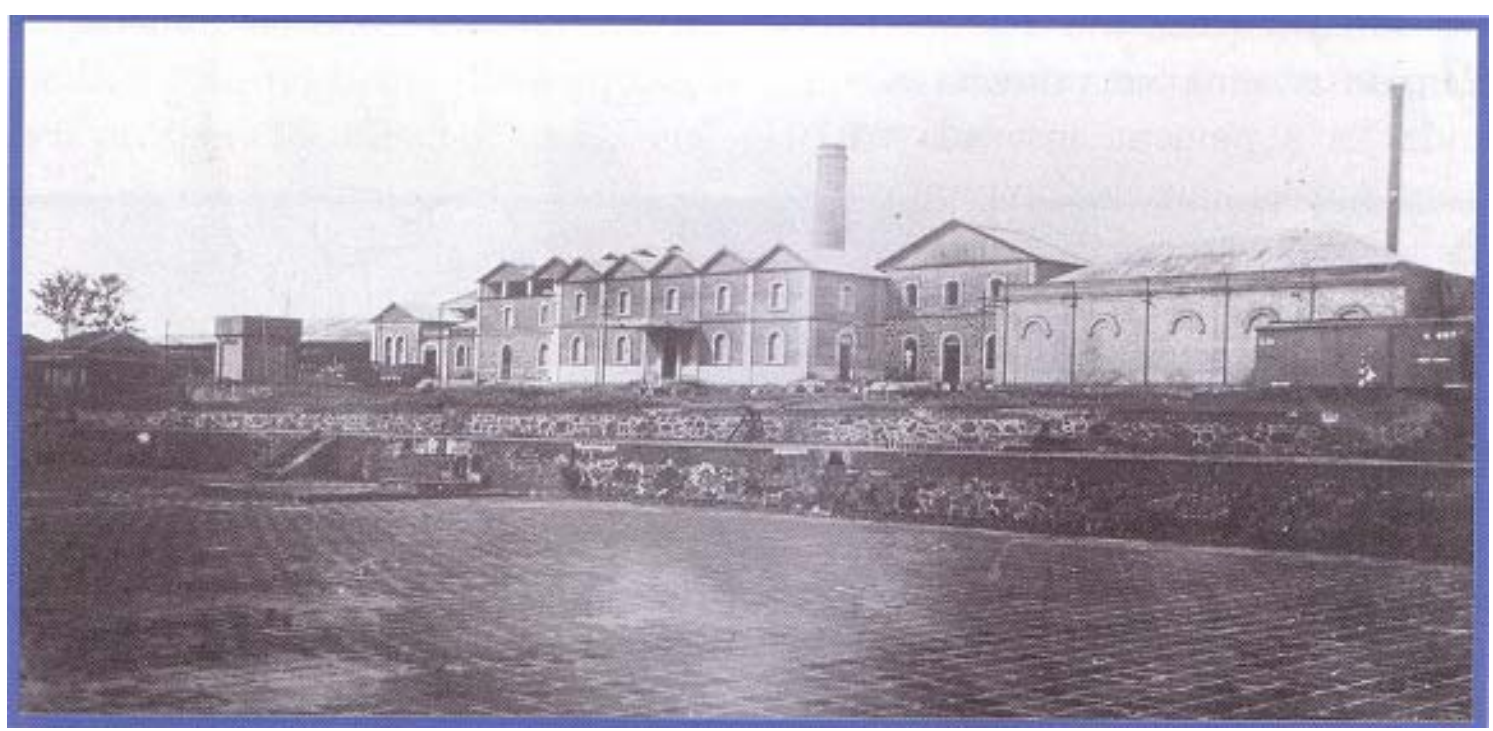

Figura 3 - Usina London, nos tempos de Dumont. Produção de "açúcar de usina” na fazenda de café. Na foto, destaque para as instalações industriais de fabricação do açúcar, acompanhada dos trilhos e de um terreiro de café na "fazenda-mista" de Dumont.

Fonte: Antunes (2006, p. 30)

De acordo com Sawyer apud Bray (1989, p.130-31), os primeiros equipamentos da usina foram adquiridos do antigo engenho Rio Bonito, de Barra do Piraí, estado do Rio de Janeiro. O autor ainda indica a venda desse primeiro maquinário, após alguns anos, ao Coronel Francisco Schmidt ${ }^{14}$, atendo sido

${ }^{13}$ Cf. CASA da Fazenda está de pé, mais de 100 anos depois. O Jornalzão, Santa Rosa de Viterbo, ano 8, nº 346, p.31, 31 ago. 2002.

${ }^{14}$ Francisco Schmidt (1855-1924) foi um dos maiores fazendeiros de café deste país, no início do século XX. Foi também o cafeicultor que mais expandiu seus domínios na última década de 1890, conforme Bray (1989, p. 133), e proprietário da conhecida Fazenda Monte Alegre, hoje parte do campus da Universidade de São Paulo, em 
adquiridos posteriormente os equipamentos de uma fábrica maior de Cachoeiro do Itapemirim, no Espírito Santo.

Conforme Andrade (1994, p. 38):

As unidades montadas nos fins do século XIX e início do século $\mathrm{XX}$, comparadas às atuais, eram pequenas, produziam pouco açúcar e mantinham a destilação de aguardente herdada dos velhos bangüês, ou instalavam pequenas destilarias de álcool hidratado. O álcool era, então, um subproduto, mas muitos usineiros, já na década de 1920, procurando novas alternativas para as suas empresas, utilizavam-no como combustível. Só nos anos 30 é que passariam a produzir o álcool anidro.

Até mesmo a energia que movia a usina de Dumont era produzida em sua propriedade. Em 1911, foi construída a Usina Hidrelétrica Itaipava (Veja as figuras 4 e 5), em área de corredeiras no Rio Pardo, entre os municípios de Santa Rosa e Cajuru. Ao contrário da fazenda Amália, a energia elétrica só chegou à jovem cidade de Santa Rosa em 1915, substituindo os lampiões movidos a querosene que iluminavam as ruas da aglomeração (ANTUNES, 2000, p. 103; 2006, p. 48).

O latifúndio de café e cana de Dumont possuía as condições materiais necessárias para viabilizar a lavoura comercial em sua propriedade: a força de trabalho, garantida pela ocupação do colono, sobretudo do imigrante; a ferrovia para transportar sua produção, a energia ${ }^{15}$ para movimentar seus negócios na grande fazenda.

Ribeirão Preto/SP. Nos primeiros anos do nascente século, adquire terras no então município de Sertãozinho, atual Pontal, onde funda a Usina Schmidt, em 1906, depois de já ter adquirido a usina Cachoeira, no município de Franca três anos antes, e ter montado engenhocas em algumas de suas fazendas e instalado a Usina Albertina, em Sertãozinho, nos anos 1920. Retomando a reflexão de Bray (1989, p. 136), já destacada anteriormente, "os casos de Dumont e Schmidt, retratam o deslocamento contínuo dos lucros da cafeicultura para a industrialização do açúcar em São Paulo, independente das crises ou apogeus da cultura cafeeira”.

${ }^{15}$ Com as modificações da configuração fundiária de Amália na década de 1990, a usina hidrelétrica de Itaipava também passa a ser propriedade da Canamor Agro-Industrial e 


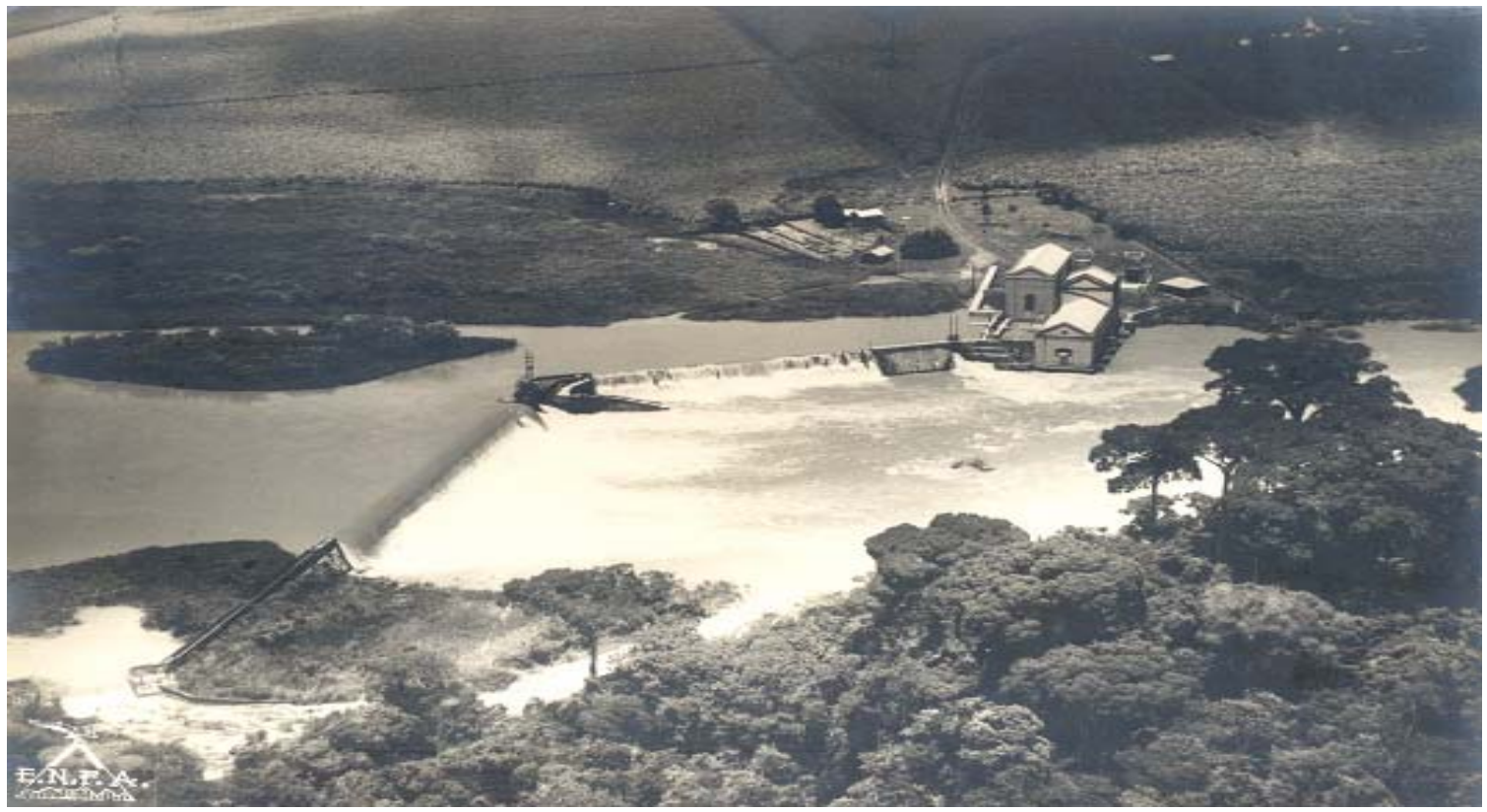

Figura 4 - Barragem de Itaipava no início dos anos 1940. A hidrelétrica fornece eletricidade para a usina de açúcar e álcool da Fazenda Amália. Rompida por uma grande enchente no Rio Pardo em meados de 1929, a barragem foi reconstruída meses depois. Na foto, destaque para a barragem e a casa de máquinas. Ao lado da construção referida, há uma subestação elétrica, e uma estreita mata ciliar, em primeiro plano, ambos cercados pelos canaviais das férteis terras de Amália.

Fonte: Acervo de Fotografias Aéreas Obliquas de 1939/1940, do Instituto Geográfico e Cartográfico.

Mercantil, atual proprietária da usina e de parte significativa da antiga fazenda. De acordo com a Resolução $\mathrm{N}^{\circ}$ 401, de 18 de outubro de 2000, da ANEEL (Agência Nacional de Energia Elétrica), a empresa supracitada, que detém os direitos de exploração da PCH (Pequena Central Hidrelétrica) de Itaipava para fins de produção independente de energia elétrica alienou à Grandview Energia Ltda, empresa com sede na capital paulista a estabelecer-se como produtor independente de energia elétrica mediante a exploração do potencial hidráulico da referida usina hidrelétrica (com 3,88 MW de potência instalada) por um período de trinta anos, a contar do dia 23 de julho de 1997, prazo este que pode ser prorrogado, à critério da ANEEL. (Cf. Resolução No 401 de 18 de outubro de 2000, da Agência Nacional de Energia Elétrica, disponível em: <www.aneel.gov.br/cedoc/res2000401.pdf>. Acesso em 21 abr. 2007 


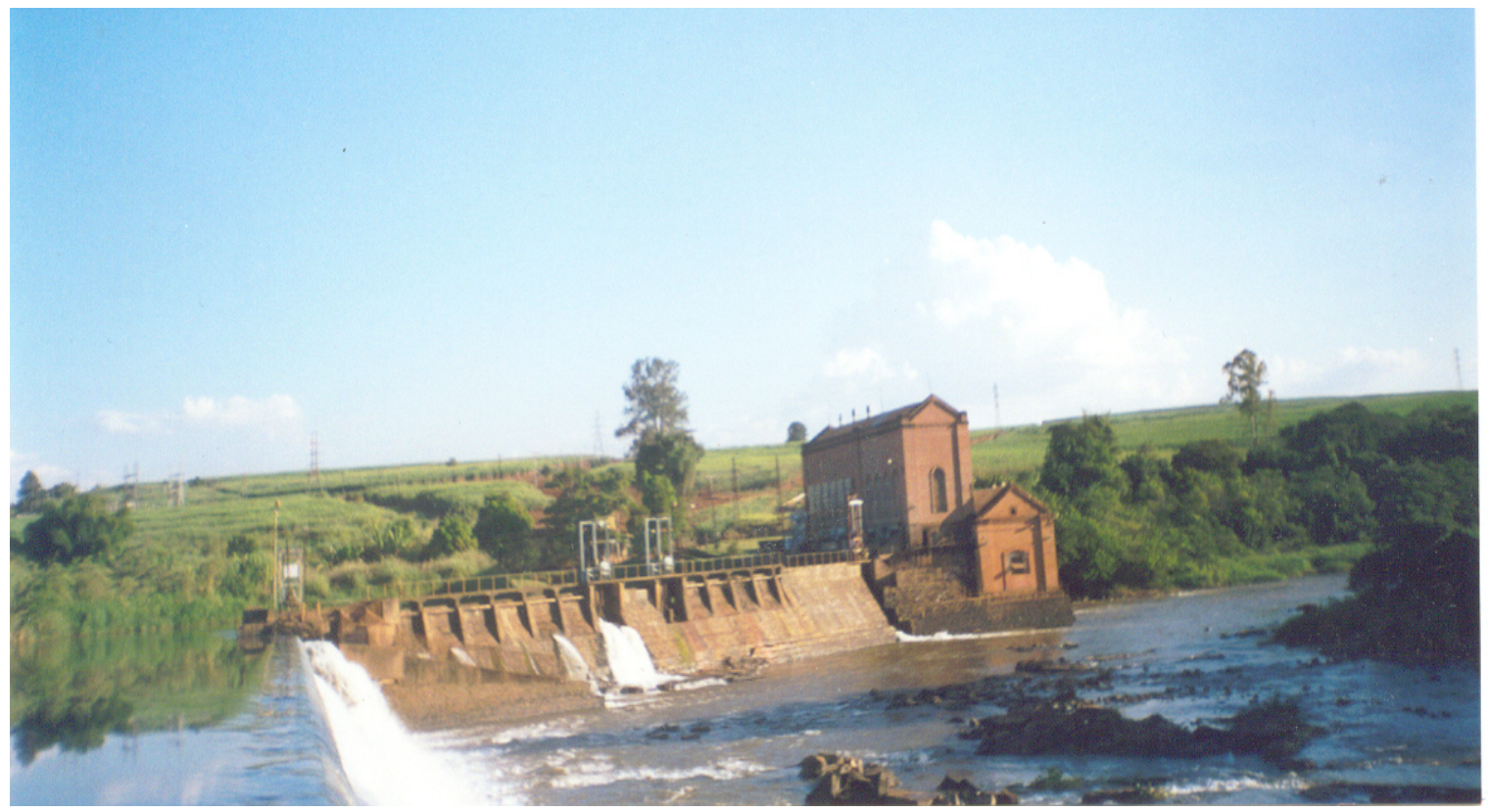

Figura 5 - Barragem de Itaipava no alvorecer do século XXI (Autor: André Eduardo Ribeiro da Silva, 21 abr.2002).

No mesmo ritmo, crescia a dependência socioeconômica dos municípios vizinhos à usina, em especial o de Santa Rosa em relação à produção agrária comandada pela grande propriedade.

Raffestin (1993, p. 230) aponta:

As relações de produção e de propriedade interagem e constituem um sistema de relações de poder. [...] A terra, sempre foi o trunfo mais ou menos disputado, conforme o lugar e o momento.

Raffestin (1993) deixa claro que as relações meramente econômicas territorializadas na propriedade fundiária são um jogo de múltiplas relações de poder, conformando uma certa territorialidade, cuja dimensão política deixa suas mais duradouras marcas.

O poder do latifúndio e da grande lavoura comercial foi fomentando o processo de territorialização da agroindústria canavieira na fazenda de Dumont. 
No entanto, como indica Bray (1989, p. 99-100) a produção do “açúcar de usina” só passa a predominar a partir de meados da década de 1920 no estado de São Paulo, ocorrendo um processo gradativo da forma de se produzir açúcar entre os engenhos tradicionais e as usinas modernas, "predominando o produzir açúcar dentro das relações de produção do capitalismo competitivo-concorrencial das pequenas e médias usinas, em detrimento do produzir açúcar de forma arcaica e tradicional das engenhocas” (Bray, 1989, p. 100).

A partir do funcionamento dos engenhos centrais paulistas, as engenhocas sempre se manifestaram grandes concorrentes das fábricas.

Esses elementos revelam que o processo de territorialização da agroindústria canavieira, tendo como base a produção de açúcar e álcool a partir da fazenda de Dumont, passou por diferentes contextos e lógicas ao longo de sua existência. Mudanças na organização do trabalho, na estrutura e gestão do capital e nas formas de se produzir seus principais produtos, mantiveram de forma implacável o controle fundiário por parte do grande capital, seja ele de origem agrária, industrial ou financeira.

Ramos (1999, p. 181) assinala a contribuição do complexo canavieiro no processo histórico de sustentação e de ampliação da concentração fundiária no Brasil, pois:

Os usineiros paulistas, assim, passaram a ser tidos como industriais e não como proprietários fundiários. Isso mitiga a importância da posse da terra no processo produtor de açúcar e álcool. Para muitos, isso parece ser coisa do Nordeste. Afinal é apenas lá que parece se dar a sustentação de algo arcaico, ultrapassado. Trata-se de um problema regional pensam muitos, de uma dominação política cuja manifestação é apenas local. (Ramos, 1999, p. 239)

Desta forma, a figura de Henrique Santos Dumont, e depois também com Francisco Matarazzo Júnior, como de usineiro vai estar encoberta pela de empresário ou industrial, camuflando faces particulares desses sujeitos sociais e a 
propriedade concentrada da terra, característica externa ao estado de São Paulo, segundo as representações da elite regional, conforme explicitado na citação acima, e símbolo do atraso conservador do latifúndio, no nordeste do país.

A plantação da gramínea, a operação dos equipamentos industriais e do ramal ferroviário, já nos primeiros anos do novo século, revelam a iniciativa precursora de Dumont na produção de açúcar industrial no nordeste paulista.

Até então, a maior parte da fabricação do açúcar de cana, nesta região e no país se dava a partir de pequenos engenhos e engenhocas (também conhecidas no estado de São Paulo por engenhos turbinados (ANDRADE, 1994 p.153), apoiada no emprego de recursos técnicos que variavam espacialmente, envolvendo desde equipamentos mais modestos como o engenho à tração animal ou práticas mais avançadas como o engenho hidráulico ou o engenho a vapor.

Entretanto, ganhava força o “processo usineiro” incentivado desde o último quartel do século XIX, com a instalação dos engenhos centrais, a maior parte deles alocados na área canavieira de Pernambuco e Rio de Janeiro, os principais processadores de açúcar industrial do Brasil.

Na então província de São Paulo, o estabelecimento dos engenhos centrais se sucedeu num momento de grande expansão dos cafezais paulistas em sua marcha rumo a novas terras no "oeste”, sobretudo no “quadrilátero açucareiro” a mais importante produtora de cana, açúcar bruto, rapadura e aguardente, "pois, com o avanço dos cafezais para as novas áreas do Oeste paulista, a população crescia e se tornava grande consumidora de aguardente, açúcar e rapadura” (BRAY, 1989, p. 59).

É nesse contexto que são iniciados os cultivos de cana-de-açúcar e a primeira montagem da usina - inicialmente denominada de Usina London, depois Usina Amália - no município de São Simão no alvorecer do século XX. O“processo usineiro” na fazenda de Dumont não contraria a lógica de valorização do capital, sustentada principalmente nesse período pela economia cafeeira. 
De acordo com Carli (1943, p. 62): “A Usina London, hoje Fazenda Amália, possuía em 1904, uma estimativa da safra de 27.000 toneladas de cana, o que era realmente uma excepcional produção para a época”, o que já conferia no ano anterior, segundo Sawyer (1905) apud Bray (1989, p. 87), a maior produção da gramínea em terras próprias no estado de São Paulo.

Essas indicações reforçam a força da cultura canavieira apoiada na grande propriedade fundiária como fundamento do processo de territorialização da agroindústria canavieira e da dependência socioeconômica dos jovens e nascentes municípios à monocultura da cana-de-açúcar e a influência dos empresários, que também se fazem usineiros e latifundiários, e seus representantes: “os donos do poder” local.

\subsection{Sociedade Agrícola Fazenda Amália: ensaio da Era Matarazzo}

Em 25 de maio de 1920, com a morte de Henrique Santos Dumont, a viúva Amália Ferreira Dumont, suas filhas e genros vendem a fazenda a uma sociedade que reunia três grandes empresários paulistas: o Conde Francesco Matarazzo, o Conde Alexandre Siciliano e o Coronel Francisco Schmidt, constituindo a Sociedade Agrícola Fazenda Amália.

Ainda nessa mesma década, Francesco Matarazzo desinteressou-se pela associação, passando sua parte para o futuro sucessor dos negócios da família, seu penúltimo filho Francisco Matarazzo Júnior (MATARAZZO 100 ANOS, s.d, p. 83).

Antunes (2006, p. 25) nos coloca que, nos anos 1920, a família do Conde Matarazzo mandou construir na fazenda uma nova edificação para servir de residência familiar e que até hoje é conhecido por “palacete”, o qual Antunes: "se localiza nas proximidades das indústrias, em patamar topograficamente mais elevado [...] de onde se descortina uma visão panorâmica de boa parte da propriedade” (ANTUNES, 2006, p. 25). Vide a figura 6. 


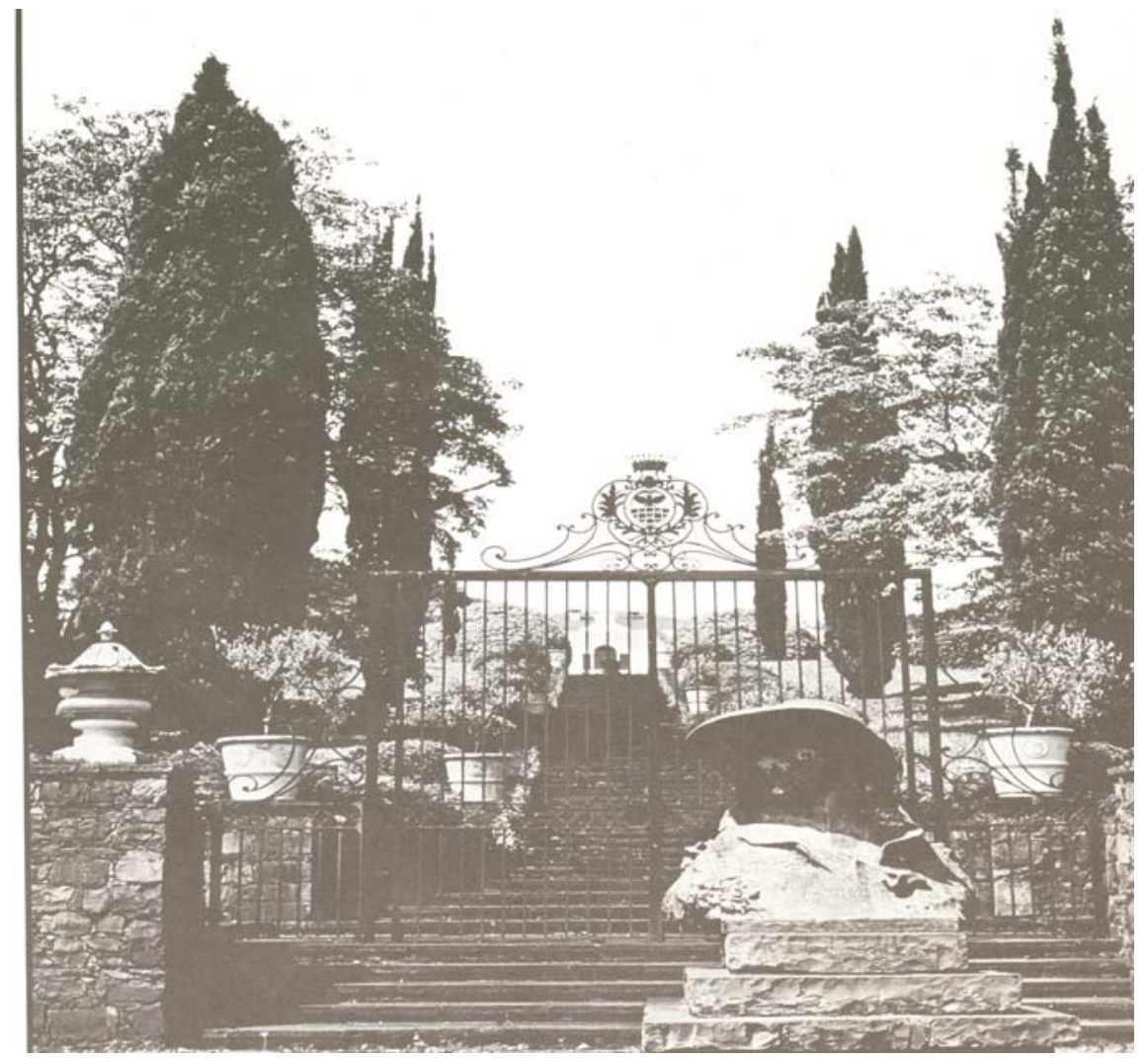

Figura 6 - Miragem nos canaviais? Entrada do "palacete” nas terras vitalícias do Conde Matarazzo Júnior, na Fazenda Amália.

Fonte: MATARAZZO 100 ANOS, s. d., p. 97.

Podemos associar essa descrição, feita por Antunes (2006), com o princípio do controle e da vigilância, presente nas obras de Michel Foucault, de controle visual de toda a propriedade a partir do princípio panóptico, neste caso, a partir do alto topográfico, da colina onde se situa o "palacete". Vê-se tudo e todos sem sequer ser notado. As dificuldades para quem está de fora da fazenda, mantidos por solicitação dos proprietários de Amália, por outro lado, são nutridas pelas representações da maior parte dos trabalhadores e moradores das cidades vizinhas que passam ou passaram pela fazenda. Uma das poucas publicações que fazem alusão à mansão da família é "Matarazzo 100 anos” que assim a descreve:

Um carinho todo especial foi dedicado à construção da nova sede e ao planejamento dos jardins, dos quais ele nunca deixou 
de cuidar. Trabalhava com grandes rolos de papel, plantas da Amália, abertos em cima da mesa, imaginando como renovar os jardins. Queria criar uma ilha de sonho onde pensava repousar e até morar, recebendo os filhos em harmonia. Amália era a "sua" casa. Aí ele gostava de receber os amigos e personalidades. O "Livro de Amália", caderno onde os visitantes costumavam escrever suas impressões sobre a fazenda tem autógrafos de figuras como Nelson Rockefeller, Dom Pedro de Orleans e Bragança, Juscelino Kubitschek e muitos amigos.Além do próprio Conde Matarazzo, que no fim da vida visitou a fazenda depois de longa ausência (MATARAZZO 100 ANOS, s. d., p. 83).

Além desses registros documentados no “Livro de Amália”, a publicação da família apresenta algumas imagens e descrições do "mundo interior do Conde Matarazzo Jr.”, um mundo que, conforme apontado acima, perfazia uma "ilha de sonho” acessível a poucos mortais, distante do poder de alcance da visão da maioria dos cidadãos de Santa Rosa de Viterbo e, particularmente, dos trabalhadores da Fazenda Amália (SILVA, 2001, p.66-7).

Moveis venezianos, jardins com afrescos florentinos, obras artísticas centenárias e raras de diversos pintores e escultores europeus, carruagens, portal que reproduzia a cidade natal do patriarca, imagens e miragens de um mundo construído sobre o suor dos trabalhadores derramado no eito dos canaviais.

A monumentalidade da residência familiar na sede da fazenda, negada ao olhar da maior parte dos moradores do lugar, também é representada pela entrada particular de acesso à fazenda, que parte do centro da cidade de Santa Rosa de Viterbo e se estende por quase cinco quilômetros ajardinados até a entrada do “palacete” em Amália, como podemos ver por meio das figuras 7 e 8. 


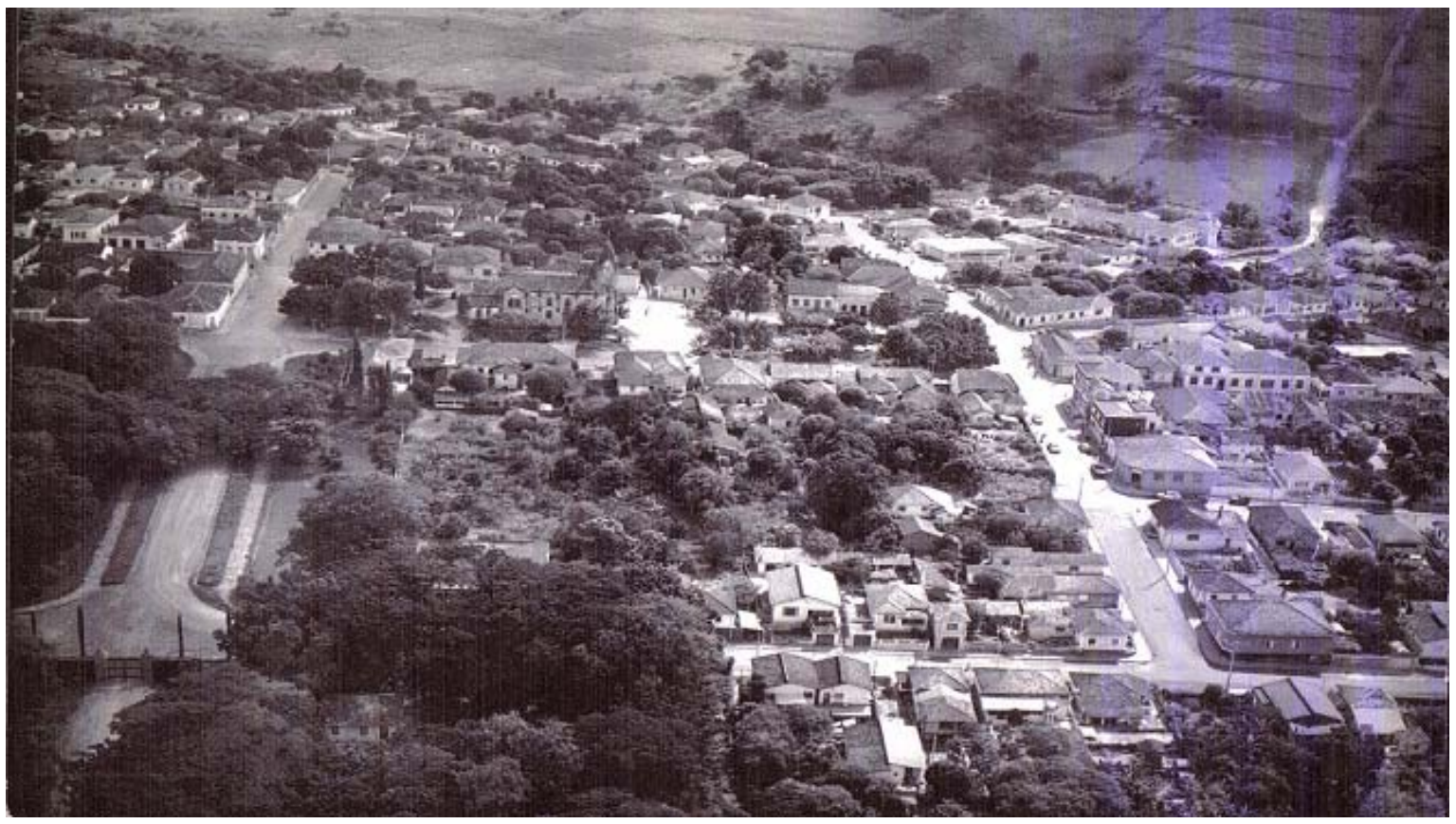

Figura 7 - "Porteira” da mansão dos Matarazzo no centro da cidade. Região central da cidade de Santa Rosa de Viterbo: destaques para a Praça Guido Maestrello (praça da Matriz) na parte superior e a atual Praça Maria Pia e o portão que conduz à estrada particular da família Matarazzo e ao "palacete”, no canto inferior. Fotografia sem data. Fonte: Fundação Cultural de Santa Rosa de Viterbo

A praça Maria Pia ${ }^{16}$, no centro de Santa Rosa de Viterbo, dá acesso ao portão que conduz à estrada familiar, escoltada por dois leões de metal e palmeiras que conferem grandiosidade e poder às terras vitalícias do Conde Matarazzo. A própria fazenda engessava os limites do crescimento urbano santarosense, uma vez que seus confrontantes eram terrenos e residências de muitos citadinos, em pleno centro urbano. É bom ressaltar que a "gleba do palacete” $(66,3 \text { hectares })^{17}$ é uma das poucas terras ainda controladas diretamente pela família Matarazzo, na antiga Fazenda Amália, nos dias de hoje.

\footnotetext{
${ }^{16}$ Maria Pia Esmeralda Matarazzo é a filha caçula do Conde Matarazzo Júnior, herdeira e sucessora do pai nos negócios da família após sua morte em fevereiro de 1977.

${ }^{17}$ Cf. Certidão de matrícula de imóveis fornecida pelo Cartório de Registro de Imóveis de Santa Rosa de Viterbo, em julho de 2006.
} 


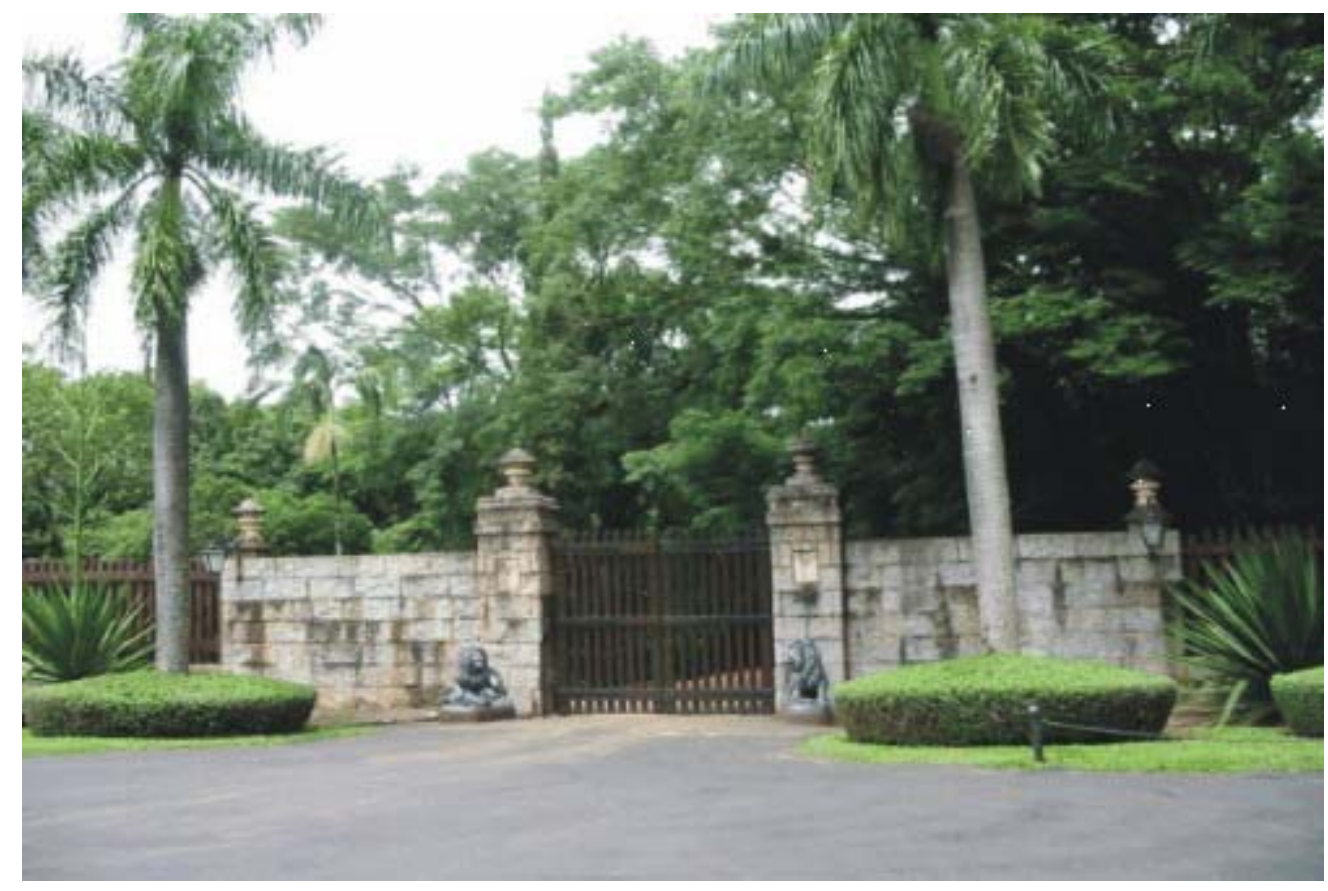

Figura 8 - Destino privativo ao "palacete”. Portão da estrada particular que conduz ao “palacete”. Praça Maria Pia, centro de Santa Rosa de Viterbo, 2004.

Disponível em: <www.santarosa.sp.gov.br> Acesso em 21 abr. 2007.

As imagens e as descrições feitas sobre a “jóia de Amália” dos Matarazzo, propriedade exclusiva da família mais rica do país, reforçam o sentido do conceito de território que vamos dando a este trabalho, ou seja, a "territorialidade não se restringe a um conjunto de relações de poder, ou melhor, é suficientemente ampla para incluir também a própria natureza econômica e simbólica do poder” como comenta Haesbaert (2004, p. 84).

A ostentação, a reprodução de mitos, símbolos e ideologias sobre o empresário, a família e as empresas Matarazzo também se enraízam no espaço, criando um território engendrado por múltiplas relações de poder. Esses poderes são sustentados pela grandiosidade do grupo familiar, por meio da visão de um “Estado Matarazzo”, conforme revela matéria jornalística do Diário da Noite, publicada em 8 de março de 1934 e mencionada em “Matarazzo 100 Anos” (s.d., p. 59-60): 
Para os que olham a unidade do Brasil como um tesouro a preservar, nenhuma organização privada possui papel mais saliente na sua defesa política quanto à cadeia de indústrias do Conde Matarazzo. [...] Há um novo Estado brasileiro. Entre as 20 unidades da Federação e mais o Distrito Federal e o Território do Acre, existe um Estado economicamente quase tão rico como São Paulo, e mais rico, como riqueza produzida, do que o erário do Distrito Federal, o de Minas ou o do Rio Grande do Sul. Quero falar do Estado Matarazzo, que não se localiza felizmente só nas terras de Piratininga, pois que abrange a geografia econômica de todo o Brasil. Enquanto São Paulo tem uma renda bruta de 400 mil contos, Minas de $140 \mathrm{mil}$, o Rio Grande do Sul de 130 mil, a Prefeitura carioca de 270 mil, o parque das IRF Matarazzo possui de receita bruta uma cifra que atinge o algarismo de 350 mil contos [...] É fora de dúvida, portanto, que o Conde Matarazzo, financeira e economicamente é o segundo Estado do Brasil. Somente o ultrapassam a União Federal, o Departamento Nacional do Café e São Paulo.

Desta forma, a Sociedade Agrícola Fazenda Amália também fazia parte do maior conglomerado industrial do país até o final da década de 1960. A grandiosidade da fazenda e de sua produção canavieira e sucroalcooleira refletia a dimensão do grupo Matarazzo na produção econômica brasileira..

Contudo, a compra em sociedade da fazenda de Dumont ocorre no mesmo ano da morte do terceiro filho (de treze) do Conde Matarazzo, considerado quase que o sucessor do patriarca nos negócios da família.

Com o falecimento de Ermelino Matarazzo ${ }^{18}$, em acidente automobilístico na Itália, em 1920, o processo sucessório nas S.A. I.R.F.M (Sociedade Anônima

\footnotetext{
${ }^{18}$ Sendo um dos filhos mais velhos e que desde cedo auxiliava nas indústrias do grupo familiar, Ermelino Matarazzo era um candidato quase que aceito ao comando das empresas do patriarca, após sua morte. Esta posição foi reforçada quando se pôs à frente da administração do grupo Matarazzo, quando da estada da família no sul da Itália, nos anos que acompanharam a Primeira Guerra Mundial. Contava com o apoio da maior parte da família em sua elevação a condição de sucessor do pai na administração dos negócios da família. Após sua morte, este processo tornou-se mais complexo, lento e disputado pelos filhos de Francesco Matarazzo, muito em função do tipo de sucessão proposta para o grupo empresarial: o controle e o comando exclusivo por apenas um dos filhos, conforme ditava o modelo empresarial seguido pelo "patriarca” (COUTO, 2004, p.211). Aqui origina também uma lacuna que vai dilacerar as S.A. Indústrias Reunidas Fábricas Matarazzo posteriormente e vai entrar para o senso comum como o principal
} 
Indústrias Reunidas Fábricas Matarazzo) se torna mais complicado; impasse que vai se estender até o final da década de 1920.

Francisco Matarazzo Júnior (1900-1977), penúltimo filho do casal de Castellabate $^{19}$, passa a auxiliar nas empresas do pai, aos 19 anos e, com a morte do irmão em 1920, torna-se um dos indicados à sucessão dos negócios da família

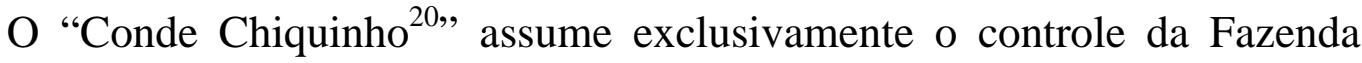
Amália, no início da década de 1930, num momento em que o Conde Matarazzo tornava-se o primeiro presidente da CIESP (1928-1931) e da FIESP (1931) (COUTO, 2004, p.145).

Neste período, a gerência da Sociedade Agrícola Fazenda Amália coube inicialmente a Manuel Carneiro da Cunha, quarto prefeito de Santa Rosa, entre 1925 e 1929 (ANTUNES, 2006, p.96). A gestão de Amália se estendia à administração municipal, isto é, a grande propriedade elegia os seus representantes no poder local.

A canavicultura paulista se expandiu grandemente em decorrência do crescimento da demanda de açúcar no mercado interno, em particular no seu

elemento responsável pela derrocada do grupo econômico: as brigas e disputas familiares por poder e pela sucessão no grupo. Processo que vai se repetir em 1977, quando da indicação da filha de Matarazzo Júnior para o comando das já milionariamente endividadas Indústrias Matarazzo.

${ }^{19}$ Castelabatte era a cidade natal do Conde Francesco Matarazzo, situada na região do Cilento, sul da Itália (COUTO, 2004, v. 1, p. 55).

${ }^{20} \mathrm{O}$ título de Conde foi consagrado a Francesco Matarazzo pelos serviços prestados à pátria italiana, pelo rei Vittorio Emmanuele, em fins de 1917 (MATARAZZO 100 ANOS, s.d., p.39). Na verdade, Francesco estabeleceu uma ponte de abastecimento entre a Itália e o Brasil, ou melhor, entre a pátria e a empresa do italiano, aumentando em muito, o rendimento e a produção do grupo familiar Mais tarde, o título de Conde é transferido aos filhos homens de Francesco Matarazzo por decreto real da Itália, datado de 4 de março de 1926, tornando-se a partir daí, um título hereditário”. Chiquinho era o pseudônimo familiar atribuído a Francisco Matarazzo Júnior, também servindo em nosso estudo para diferenciar o Conde Matarazzo (o italiano Francesco Matarazzo, o "patriarca" das S.A.Indústrias Reunidas Fábricas Matarazzo) do Conde Matarazzo Júnior (o filho brasileiro do Conde Matarazzo e sucessor na administração dos negócios da família, após sua morte em 1937) (COUTO, 2004, p. 248, 250). 
mercado regional e de estados próximos, e das perspectivas de crise na produção cafeeira em decorrência do arrefecimento do preço da rubiácea no mercado externo.

Na segunda metade da década de 1920, a introdução de novas variedades da gramínea em combate às moléstias que afligiam os canaviais do estado de São Paulo (praga do mosaico), elevou substancialmente a produção estadual, contribuindo muito para a consolidação da forma industrial de se produzir açúcar em São Paulo, em detrimento da produção dos engenhos turbinados e engenhocas (Andrade, 1994, p.56). O “processo usineiro” alavancava a produção açucareira paulista.

No final dos anos 1920, a produção de café da Fazenda Amália se restringia a 33 mil pés de café em seu território (ANTUNES, 2006, p. 58) e a produção de açúcar era, na safra 1930/1931, de 135.490 sacas de $60 \mathrm{Kg}$, a maior do estado de São Paulo, sendo que até o final dos anos 1940 não deixou de estar entre as sete maiores produções açucareiras do estado. Estava mais que inaugurada a territorialização da agroindústria canavieira associada à “Era Matarazzo” na Fazenda Amália.

\subsection{A Fazenda Amália de Matarazzo Júnior}

A Fazenda Amália, a partir do início da década de 1930, passou a ser propriedade exclusiva do grupo Matarazzo, capitaneado por Francisco Matarazzo Júnior. 
Desde o início de sua constituição, a Fazenda Amália foi adquirindo outras propriedades próximas, constituindo uma área contínua de terras, dividida em várias seções, muitas delas comportando inúmeras colônias de trabalhadores. As seções da Fazenda Amália existentes até o fim das colônias, em meados da década de 70 eram: Santa Sofia, Sede (Bela Vista), Fazendinha, Bananal, Boa Vista, São Lourenço, Parasito, Santa Filomena, Graciosa, Cachoeira, Cruz da Esperança, Modesta, Alambari, Baixão, Morrinhos, Estela Maris, Fonseca, Campo de Semente e Corvo Branco. (ANTUNES, 2000, p.142)

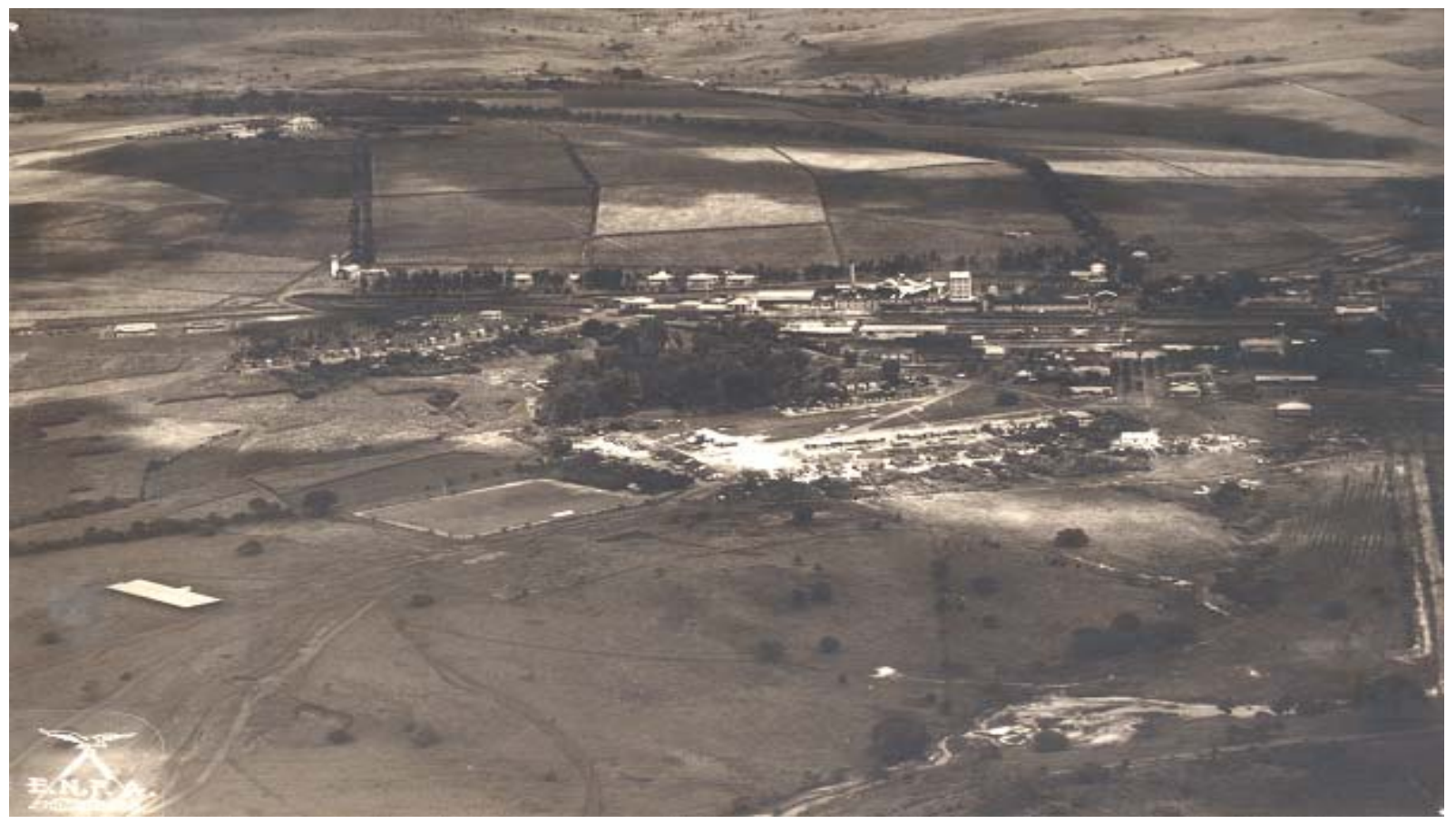

Figura 9 - Colônia-sede da Fazenda Amália (Bella Vista). Destaque para a usina do mesmo nome, no fim dos anos 1930.

Fonte: Acervo de fotografias aéreas obliquas 1939/1940, do Instituto Geográfico e Cartográfico. 


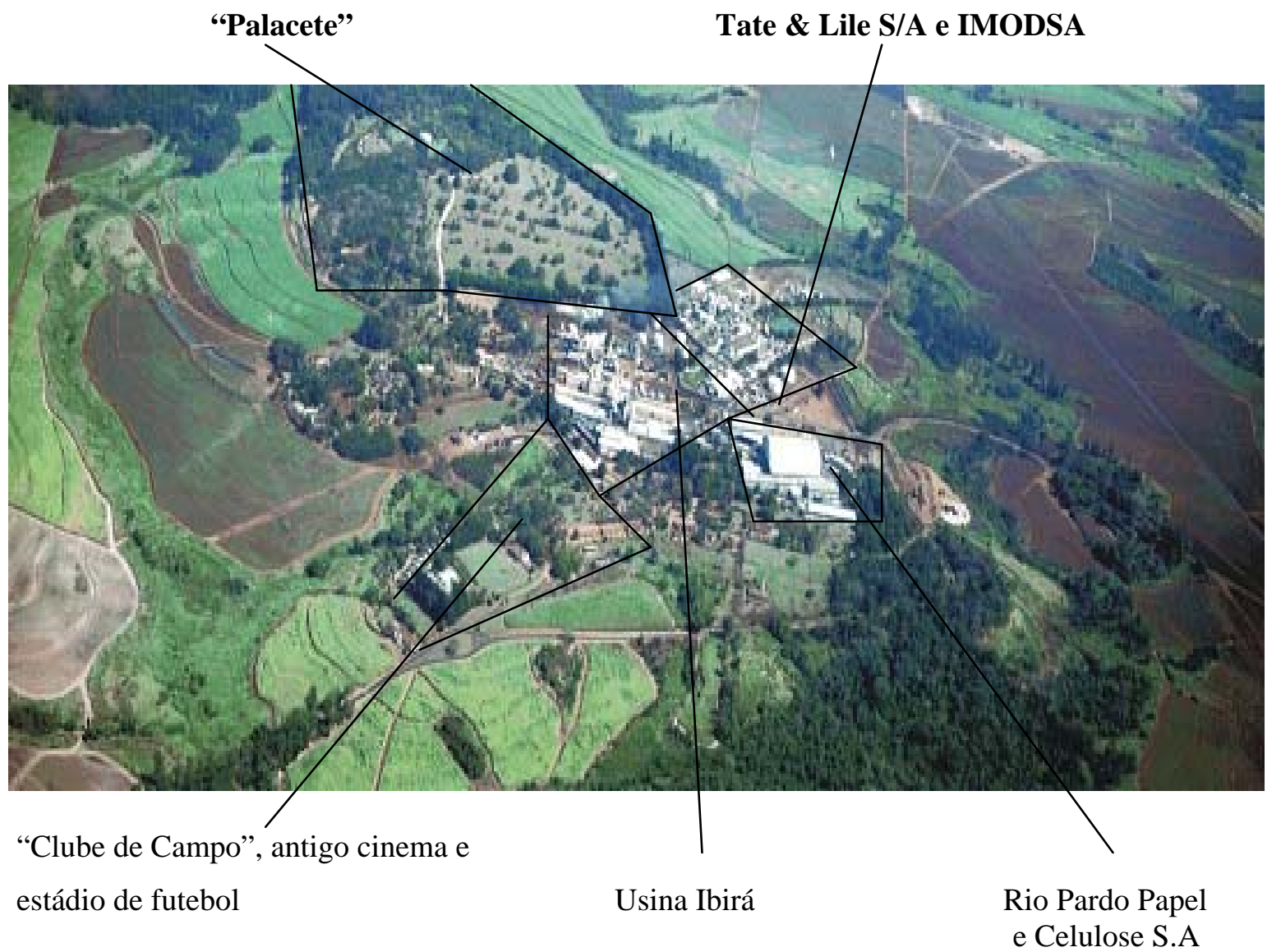

Figura 10 - Sede da Fazenda Amália, nos primeiros anos do século XXI.

Disponível em: <www.santarosa.sp.gov.br> Acesso em 21 abr. 2007

A propriedade apresentava onze mil alqueires (26.400 hectares) com sede na porção norte do município Santa Rosa de Viterbo, nas proximidades do médio Rio Pardo, onde se encontrava uma usina do mesmo nome. Suas terras também eram distribuídas pelos atuais municípios de Cajuru, Tambau, São Simão, Serra Azul (emancipado do município de São Simão em 1927) e Santa Cruz da Esperança (emancipado do município de Cajuru em 1993). Veja o mapa 3 na página seguinte. 

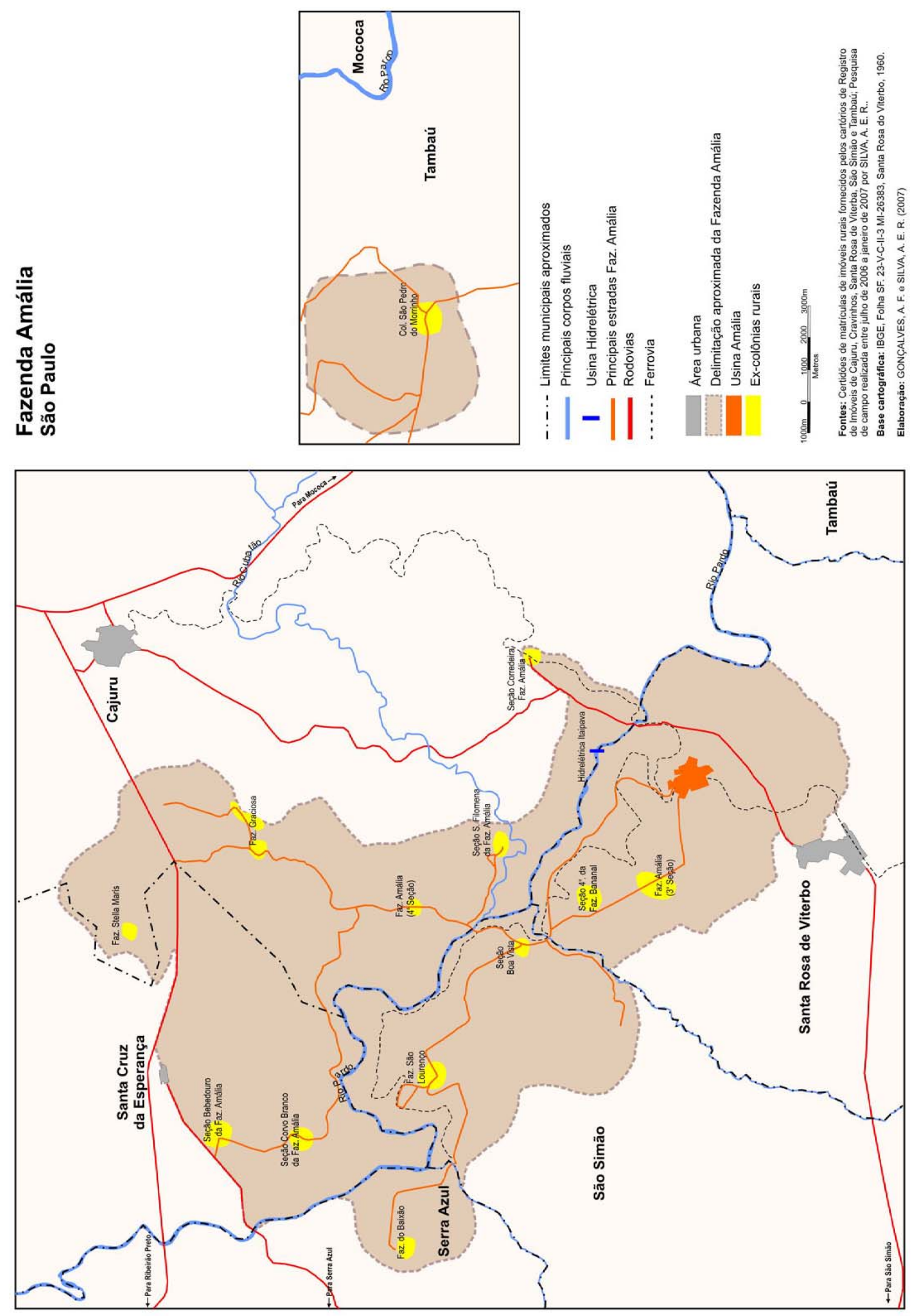
É nos anos 1930 em que também se dá o movimento de instalação das fábricas de algodão Matarazzo pelo interior paulista. A implantação das indústrias de beneficiamento do algodão e a conseqüente descentralização das unidades montadas na capital paulista estão relacionados ao momento favorável de expansão da cotonicultura pelo estado de São Paulo, na década de 1930, ocasião que permitiu ao país tornar-se o primeiro produtor mundial de algodão e de óleo de caroço da malvácea.

Este movimento segue a estratégia empresarial do grupo familiar e do padrão de industrialização da época, baseado na maximização do aproveitamento da matéria-prima industrial, estratégia que também será adotada na Fazenda Amália, a partir dos anos 1930, já pelo sucessor do Conde Matarazzo na administração dos negócios do grupo familiar, ou seja, Francisco Matarazzo Júnior, como pode ser visto na figura 11 abaixo.

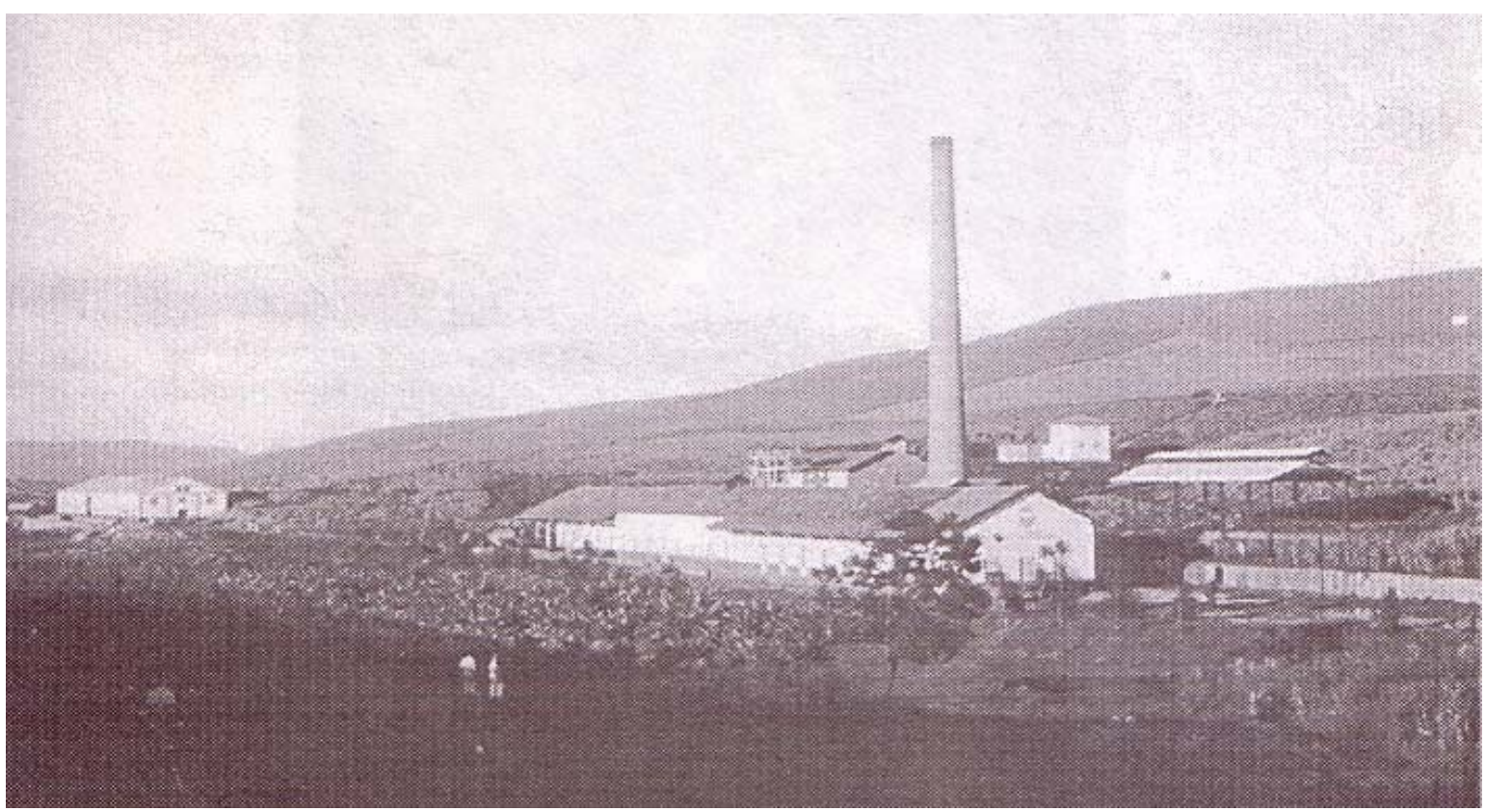

Figura 11 - Fábrica de conservas e de amido de mandioca na seção Fazendinha da Fazenda Amália. Os prédios construídos entre 1943 e 1945 para abrigar as fábricas de conservas da Fazendinha (produção de doces de goiaba, marmelo, extrato de tomate e amido de mandioca) ainda existem e vêm sendo utilizados como depósito de açúcar pela Usina Ibirá.

Fonte: Antunes (2000, p.201). 
Na Fazenda Amália, a fábrica de conservas e de amido de mandioca, na seção Fazendinha inseria-se nessa lógica de maximização do aproveitamento industrial, mas principalmente, do tempo de trabalho dos colonos, visto que a maior demanda de labor nos canaviais envolvia três ou quatro meses até meados dos anos 1950, como iremos referir mais à frente neste trabalho.

Por meio de uma reconstrução histórica que permite desvendar uma parte importante do processo de industrialização ocorrida no interior paulista, Vichnewski (2004) elaborou um inventário detalhado das 24 indústrias de algodão implantadas em 17 cidades do interior paulista entre 1930 e 1960.

A pesquisa de Vichnewski (2004) permite uma discussão a respeito da preservação do patrimônio industrial no Brasil nos dias de hoje, mais especificamente de um dos mais importantes grupos econômicos que contribuíram para o processo de industrialização deste país, as fábricas controladas por Francesco Matarazzo.

A situação de abandono da maioria das instalações fabris, examinadas por Vichnewski (2004), em parte pode ser somada à destruição do universo material produzido na Fazenda Amália, como as antigas fábricas, o hospital Santo André, o antigo cinema, as colônias de trabalhadores, as lembranças que ainda estão muito presentes na memória da população de várias cidades próximas e mesmo distantes da grande fazenda ${ }^{21}$.

Possibilitou a identificação de um padrão industrial e as relações estabelecidas entre as várias empresas Matarazzo entre as décadas de 1930 e 1960.

Esses elementos nos permitem afirmar que não podemos entender o processo de territorialização da agroindústria canavieira sob o controle da S.A.

${ }^{21}$ Para mais informações a respeito da reprodução cultural de parte das lembranças dos colonos da Fazenda Amália nos dias de hoje, ler o artigo intitulado "A Cultura na Esteira do Tempo", de autoria da socióloga Maria Aparecida de Moraes Silva, publicado na revista São Paulo em Perspectiva, vol 15, $\mathrm{n}^{0} 3$ São Paulo: Julho/Setembro de 2001. P.102-12. Este texto também está disponível em: <www.scielo.br/scielo.php> . Acesso em 23 jun. 2007. 
Indústrias Reunidas F. Matarazzo sem considerar o intercâmbio da unidade sucroalcooleira da Fazenda Amália com a dinâmica das demais indústrias Matarazzo - o maior grupo econômico latino-americano até a década de 1960 -, inclusive com as fábricas construídas na mesma fazenda.

A Fazenda Amália chegou a possuir a quarta maior linha ferroviária particular paulista no final da década de 1930. Eram 52 quilômetros de trilhos de uma extensão total de 441quilômetros entre as usinas no estado de São Paulo, herança dos tempos de Dumont.(Anuário Açucareiro 1940. Rio de Janeiro: IAA, p. 42). Vide as figuras 12 e 13.

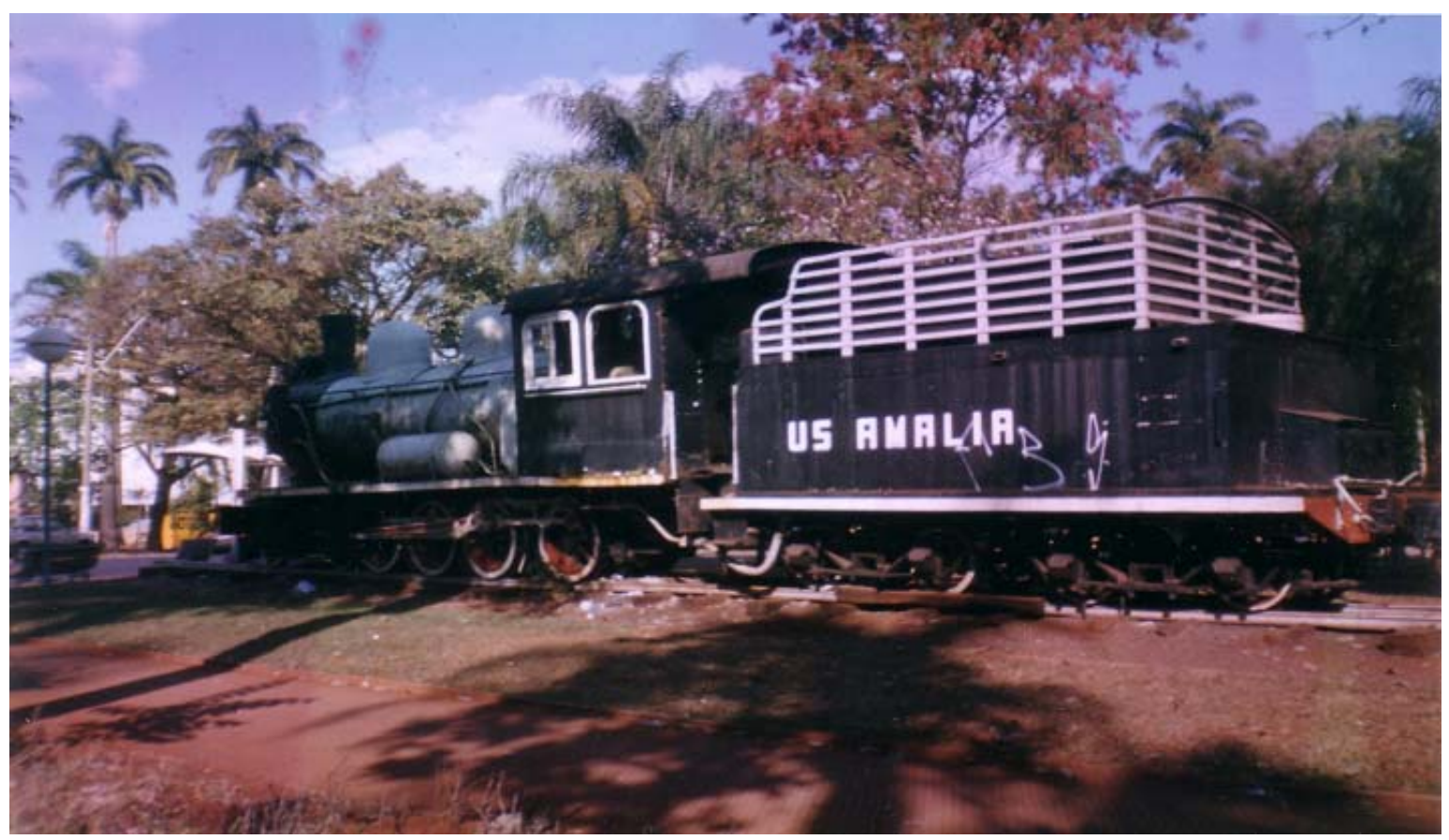

Figura 12 - Locomotiva utilizada na Fazenda Amália, exibida na Praça Francisco Schmidt, em Ribeirão Preto/SP.

(Autor: André Eduardo Ribeiro da Silva, 18 set. 2006). 


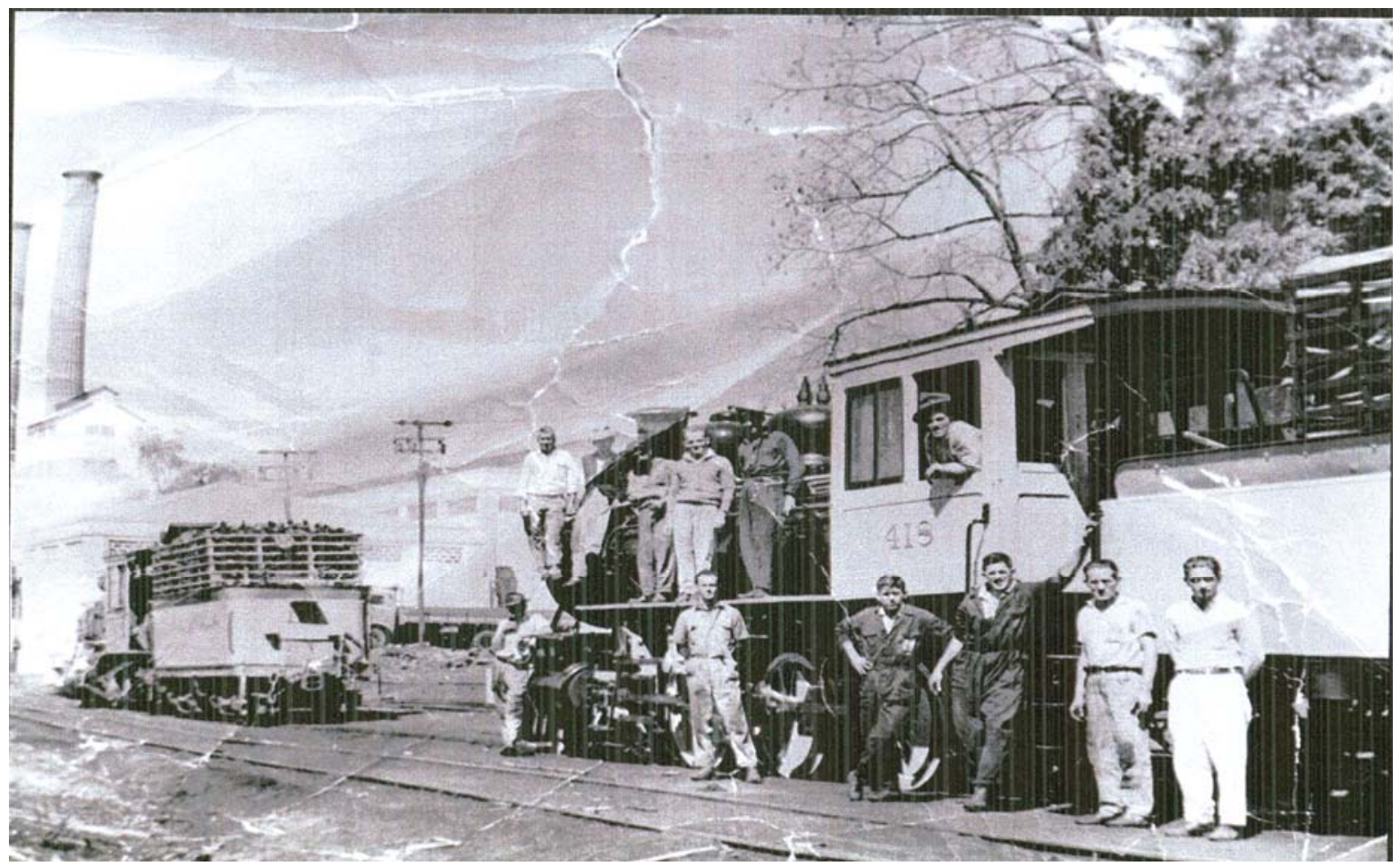

Figura 13 - Trabalhadores da ferrovia interna da Fazenda Amália. Fotografia sem data Fonte: Fundação Cultural de Santa Rosa de Viterbo.

A pressão política dos produtores de cana-de-açúcar faz apelo à intervenção governamental no subsetor, resultando na criação, no início dos anos 1930, da Comissão de Estudos sobre o Álcool Motor (CEAM), órgão de incentivo à indústria alcooleira nacional e, a Comissão de Defesa da Produção de Açúcar (CDPA) (SZMRECSÁNYI, 1979, p.171,173).

Com isto, o governo pretendia dinamizar a produção nacional de álcool carburante, visto que, até 1930, o consumo do álcool era voltado principalmente para o comércio e como insumo para a indústria química e farmacêutica. O uso do álcool, como combustível, no máximo, se limitava às áreas próximas às usinas e convertia-se numa "válvula de escape” para a agroindústria açucareira.

Ainda no início da década de 1930, da fusão da CEAM e da CDPA, em 1933, foi criado o IAA (Instituto do Açúcar e do Álcool). No tocante a criação 
dessa autarquia estatal para regular a produção canavieira nacional, assim coloca Szmrecsányi (1979, p.177):

A intervenção governamental, antes exercida em caráter provisório por órgãos de emergência, passou a ser definitiva e atribuída a um órgão permanente. Entidade de caráter autárquico, o Instituto recebeu o encargo de dirigir, fomentar e controlar a produção de açúcar e álcool em todo o país. Ele passou a responder não apenas pela soma das atribuições dos órgãos que o precederam, mas por muitas outras que lhes foram sendo acrescidas com o correr dos anos. Foi, portanto com o IAA que realmente teve início o processo de planejamento na agroindústria canavieira.

A intervenção estatal no setor sucroalcooleiro do país, deu-se principalmente, por meio de uma série de políticas e medidas para controle dos preços e da produção (política de quotas de produção por estados e estabelecimentos industriais).

Ela ocorria ao mesmo tempo em que intensificava a constituição das usinas, acentuando o conflito entre os capitalistas agroindustriais e os engenhos, sendo que muitos desses últimos, com o advento das usinas foram reduzidos a fornecedores de cana, especialmente no Nordeste.

Do início da década de 1930 até a implantação do Instituto do Açúcar e do Álcool, em 1933, havia um grande domínio do Nordeste na produção açucareira, seguido pelo Rio de Janeiro, a tal ponto que, das 13 usinas com maior capacidade de produção, dez se localizavam no Nordeste, uma no Rio de Janeiro e uma em São Paulo (ANDRADE, 1994, p.164) ${ }^{22}$.

\footnotetext{
${ }^{22}$ Segundo Andrade (1994, p. 64), das dez usinas nordestinas, Pernambuco ficava com as três que estavam nos primeiros lugares: Catende, Tiúma e Santa Terezinha e ocupava o quinto lugar com o Engenho Central Barreiros, o sétimo com a União e Indústria, o décimo com a São João da Várzea e o duodécimo com a Salgado. Alagoas possuía a quarta colocada, a Central Leão, a sexta, a Usina Brasileiro, e a nona, a Usina Serra Grande. No Rio de Janeiro, situava-se a décima primeira, a Usina Quissamã, e a décima terceira, a Usina São José. Em São Paulo, situava-se a oitava colocada, a Usina Junqueira, fundada na década de 1920, por Quito Junqueira. Já segundo o Anuário
} 
Em São Paulo, por ser um centro de produção para o consumo, o processo foi diferente do nordestino e fluminense, tendo surgido, desde os fins do século passado, um grande número de refinarias de açúcar, pertencentes ora a comerciantes, alguns deles imigrantes italianos estabelecidos nas cidades, ora aos próprios usineiros. O capital comercial, ou oriundo de outros setores industriais, conquistou os detentores do capital agrário para o controle da produção de açúcar, a tal ponto que, no período entre 1930 e 1946, os quatro maiores produtores paulistas eram a Société des Sucreries Brésilliennes, detentora de quatro usinas e de quatro destilarias de álcool anidro, o grupo Morganti que controlava a Refinaria Paulista, o fazendeiro Francisco M..Junqueira e o grupo Matarazzo [RAMOS, 1983, p. 74] (ANDRADE, 1994, p.168-69), conforme revela a tabela 1 , na página seguinte.

A tabela supramencionada, nos revela a expansão do "processo usineiro" associada à concentração econômica no setor canavieiro nas décadas de 1930 e 1940, com destaque para os quatro primeiros grupos usineiros que controlavam mais da metade da produção estadual no período considerado. As usinas eram responsáveis pela maior parte da produção açucareira paulista, produção esta assentada em um número limitado de processadoras industriais, na maior parte dos casos, a única empresa canavieira desses grupos econômicos, como ocorre com o grupo Matarazzo, em questão.

O grupo Matarazzo, proprietário da Usina Amália, foi um dos maiores grupos usineiros paulistas, entre as décadas de 1930 e 1940, responsável por 7,9\% da produção do açúcar industrial no estado de São Paulo no início da década de 1940, momento em que 87,6\% da produção estadual provém de usinas, conforme Ramos (1999 p.76).

Açucareiro para 1935 (p. 20), a Usina Amália foi no qüinqüênio 1929/1930, a $3^{\text {a }}$ produtora estadual e a $11^{\mathrm{a}}$.produtora nacional de açúcar, respectivamente, produzindo 700.790 sacos de $60 \mathrm{Kg}$ de açúcar, o que equivalia a 9,6\% da produção paulista e 1,6\% da brasileira. 
Tabela 1

Os maiores grupos usineiros paulistas das décadas de 1930 e 1940

\begin{tabular}{|c|c|c|c|c|c|c|}
\hline \multirow[b]{2}{*}{ Grupos usineiros } & \multicolumn{2}{|c|}{ 1930/1931 - 1935/1936 } & \multicolumn{2}{|c|}{ 1936/1937 - 1940/1941 } & \multicolumn{2}{|c|}{ 1941/1942 - 1945/1946 } \\
\hline & $\begin{array}{l}\text { Número de } \\
\text { usinas }\end{array}$ & $\begin{array}{c}\text { \% Produção } \\
\text { Total }\end{array}$ & $\begin{array}{l}\text { Número } \\
\text { de usinas }\end{array}$ & $\begin{array}{c}\text { \% Produção } \\
\text { Total }\end{array}$ & $\begin{array}{l}\text { Número } \\
\text { de usinas }\end{array}$ & $\begin{array}{c}\text { \% Produção } \\
\text { Total }\end{array}$ \\
\hline Société des S. Brésil & 4 & 28,2 & 3 & 24,8 & 3 & 20,8 \\
\hline Morganti & 2 & 17,3 & 2 & 17,6 & 2 & 17,4 \\
\hline F. Junqueira & 1 & 9,8 & 1 & 9,2 & 1 & 9,4 \\
\hline Matarazzo & 1 & 8,9 & 1 & 7,9 & 1 & 7,9 \\
\hline Alves de Almeida & 1 & 7,9 & 1 & 7,2 & 1 & 6,2 \\
\hline Nogueira & 1 & 5,7 & 1 & 5,1 & 1 & 5,5 \\
\hline G. Schmidt e Irmãos & 2 & 3,8 & - & - & - & - \\
\hline Reis de Magalhães & 1 & 3,5 & 1 & 3,5 & - & - \\
\hline Francisco Frascino & - & - & 1 & 3,3 & - & - \\
\hline João B. L. Figueiredo & - & - & - & - & 1 & 3,0 \\
\hline Monteiro de Barros & - & - & - & - & 1 & 2,9 \\
\hline Demais Grupos & 18 & 14,9 & 33 & 21,4 & 27 & 26,9 \\
\hline Total & 31 & 100 & 33 & 100 & 38 & 100 \\
\hline
\end{tabular}

Fonte:Ramos (1983, p. 74)

Neste ínterim, apesar de sustentar-se no setor têxtil, no ramo alimentício e na moagem de trigo, em suas fábricas situadas principalmente na capital paulista, havia, entre as chaminés de Francesco Matarazzo, uma refinação de açúcar. Ela foi criada em 1910, num conjunto de fábricas do industrial no bairro da Mooca, na cidade de São Paulo, e transferida posteriormente, em 1920, para o Parque Industrial da Água Branca, como menciona Couto (2004, p. 63, 65, 328) e Vichnewski (2004, p. 62).

O industrial italiano era proprietário da Sociedade Paulista de Navegação Matarazzo Ltda, criada em 1919, e que se encarregava do transporte de 
cabotagem, especialmente do trigo argentino para seus moinhos em São Paulo, por meio de docas e instalações portuárias próprias (COUTO, 2004, p. 41- 2), mas também do transporte de charque, entre o Rio Grande do Sul e o Rio Grande do Norte e do açúcar da Mata nordestina principalmente para os mercados do Distrito Federal e o estado de São Paulo, principais centros consumidores do produto.

Bray (1989, p.121) aponta a disputa da refinaria de açúcar dos Matarazzo com a refinaria União, do grupo Morganti pelo mercado atacadista paulista, entre os anos que acompanharam a crise do café (1926-1932).

Dessa forma, podemos notar o envolvimento das indústrias Matarazzo nos negócios relacionados ao transporte (navegação de cabotagem), refino (fábrica no Parque Industrial da Água Branca, na cidade de São Paulo) e produção (Fazenda Amália) do açúcar desde as primeiras décadas do século XX.

A produção açucareira da Usina Amália (Vide Tabela 2) fortalecia o “processo usineiro” paulista, pelo volume produzido, situando-se entre as sete maiores fabricantes estaduais do produto, como demonstra a tabela 2, mesmo com as limitações de produção impostas pelo IAA, muitas vezes dribladas pelas unidades industriais (Ramos, 1999, p.143). 
Tabela 2

Usina Amália (Safras 1930/1931 - 1949/1950)

Produção de açúcar (sacos de $60 \mathrm{Kg}$ )

\begin{tabular}{|c|c|}
\hline Safra & Produção de açúcar \\
\hline $1930 / 1931$ & $135.490\left(1^{\circ}\right)$ \\
\hline $1931 / 1932$ & $127.500\left(7^{\circ}\right)$ \\
\hline $1932 / 1933$ & $152.500\left(4^{\circ}\right)$ \\
\hline $1933 / 1934$ & $183.300\left(3^{\circ}\right)$ \\
\hline $1934 / 1935$ & $151.102\left(5^{\circ}\right)$ \\
\hline $1935 / 1936$ & $160.870\left(5^{\circ}\right)$ \\
\hline $1936 / 1937$ & $179.520\left(7^{\circ}\right)$ \\
\hline $1937 / 1938$ & $170.886\left(7^{\circ}\right)$ \\
\hline $1938 / 1939$ & $189.100\left(5^{\circ}\right)$ \\
\hline $1939 / 1940$ & $175.947\left(6^{\circ}\right)$ \\
\hline $1940 / 1941$ & $201.292\left(5^{\circ}\right)$ \\
\hline $1941 / 1942$ & $207.300\left(1^{\circ}\right)$ \\
\hline $1942 / 1943$ & $230.650\left(3^{\circ}\right)$ \\
\hline $1943 / 1944$ & $223.790\left(4^{\circ}\right)$ \\
\hline $1944 / 1945$ & $230.662\left(3^{\circ}\right)$ \\
\hline $1945 / 1946$ & $225.170\left(4^{\circ}\right)$ \\
\hline $1946 / 1947$ & $270.640\left(7^{\circ}\right)$ \\
\hline $1947 / 1948$ & $286.590\left(6^{\circ}\right)$ \\
\hline $1948 / 1949$ & $301.366\left(3^{\circ}\right)$ \\
\hline $1949 / 1950$ & $262.410\left(6^{\circ}\right)$ \\
\hline
\end{tabular}

Obs: Os ordinais entre parênteses representam a posição da produção de açúcar da Usina Amália em relação ao conjunto da produção açucareira do estado de São Paulo nos períodos de safra da cana-de-açúcar.

Fonte: Anuário Açucareiro do IAA. Anos 1938, 1939, 1941, 1942,1945/1946/1947 e 1949-50.

Contudo, restrições à produção canavieira foram deixadas de lado no decorrer da Segunda Guerra Mundial, em virtude da guerra submarina que prejudicou o transporte de cabotagem do açúcar da Mata para o Centro-Sul do país, comprometendo o abastecimento do maior mercado consumidor interno do produto. 
Em contrapartida, o IAA lançou mão de uma série de medidas para contornar o problema de transporte, entre elas, a permissão para a implantação de novas unidades produtoras, assim como a liberação de quotas de produção para as usinas da região Centro-Sul canavieira, haja visto os problemas de escoamento da produção nordestina.

Em compensação, o “processo usineiro” se ancorava na continuidade e mesmo acentuação da concentração fundiária, principalmente a partir do controle direto, por parte dos grupos usineiros, do fornecimento da maior parte da matéria-prima a ser consumida no processo produtivo principalmente para a fabricação do açúcar e, depois, também do etanol.

Carli (1943) fez um estudo sobre as origens e a dinâmica da agroindústria paulista, constatando uma forte concentração no setor decorrente do domínio de amplas porções territoriais de vários municípios no estado pela monocultura da gramínea praticada por importantes grupos usineiros.

O autor destaca o município de Santa Rosa ( com 25.400 hectares cultivados com cana-de-açúcar), juntamente com o de Pontal (com 31.800 hectares plantados da gramínea), distinguindo-os dentre os municípios canavieiros paulistas por:

apresentarem uma alta percentagem de áreas cultivadas com cana-de-açúcar, em relação às áreas de todas as culturas submetidas à apreciação. Com uma percentagem superior a 50\%, esses municípios denotam uma acentuada ocupação do solo com a gramínea açucareira (CARLI, 1943, p. 147).

Tem-se aí, a continuidade de um processo de concentração fundiária, lógica que se estabelece a partir da territorialização da atividade agroindustrial canavieira e do aprofundamento das relações capitalistas de produção, processo que será acentuado duas décadas depois, mas que já se encontra em gestação, nutrindo cada vez mais o grau de dependência de Santa Rosa de Viterbo e 
municípios vizinhos em relação à monocultura da cana cultivada na Fazenda Amália.

Podemos, então indicar a marca registrada que acompanhou o processo de territorialização das grandes unidades processadoras de cana-de-açúcar, no estado de São Paulo, incluindo a Usina Amália: a concentração fundiária associada à formação de canaviais pelas próprios estabelecimentos industriais.

Nas décadas de 1950 e 1960, intensifica-se o “processo usineiro” nas escalas estadual e nacional. A partir de meados da década de 1950, a produção sucroalcooleira do estado de São Paulo passa a ser a maior do país, como revelam os dados do IAA, conforme revela a Tabela 3, na página seguinte.

A expansão da produção açucareira, na década de 1950, deriva de três elementos: a expansão da capacidade instalada das usinas; a concentração e centralização do capital agroindustrial canavieiro, por meio da aquisição de usinas e das quotas daquelas que não conseguiam acompanhar o processo de capitalização do setor tanto na parte industrial como na agrícola; e inovações técnicas, que possibilitaram grande aumento da produção, muitas vezes até superior ao consumo interno (THOMAZ JR, 1988).

Na década seguinte, o aumento da capacidade produtiva das usinas, nos anos 1950, gerou uma superprodução de açúcar, excedente este que passou a ser orientado por meio de uma série de medidas adotadas pelo IAA ao mercado externo. Dentre elas, estava a norma da autarquia estatal determinando que o total de açúcar a ser produzido dependeria não mais da capacidade de produção, mas pelo consumo interno e as necessidades do mercado externo (THOMAZ JR, 1988). 
Tabela 3

Estado de São Paulo e Brasil (Safras 1950/1951 - 1965/1966)

Moagem de cana-de-açúcar nas usinas (em toneladas)

\begin{tabular}{|c|c|c|c|}
\hline \multirow{2}{*}{ Safras } & \multicolumn{2}{|c|}{ Estado de São Paulo } & Brasil \\
\cline { 2 - 4 } & Produção (em ton.) & Em \% do país & Produção (em ton.) \\
\hline $1950 / 1951$ & 4.216 .815 & 27,2 & 15.482 .576 \\
\hline $1951 / 1952$ & 5.106 .707 & 30,1 & 16.956 .840 \\
\hline $1952 / 1953$ & 6.155 .991 & 30,6 & 20.116 .604 \\
\hline $1953 / 1954$ & 8.042 .500 & 36,4 & 22.059 .885 \\
\hline $1954 / 1955$ & 9.221 .994 & 39 & 23.668 .104 \\
\hline $1955 / 1956$ & 8.120 .114 & 34,4 & 23.579 .113 \\
\hline $1956 / 1957$ & 8.849 .087 & 36,3 & 24.378 .322 \\
\hline $1957 / 1958$ & 12.701 .687 & 42,5 & 29.893 .819 \\
\hline $1958 / 1959$ & 17.038 .530 & 47 & 36.243 .352 \\
\hline $1959 / 1960$ & 14.202 .463 & 41,3 & 34.389 .637 \\
\hline $1960 / 1961$ & 16.013 .416 & 43,8 & 36.548 .434 \\
\hline $1961 / 1962$ & 15.037 .931 & 41,3 & 36.445 .596 \\
\hline $1962 / 1963$ & 15.700 .693 & 47,1 & 33.316 .552 \\
\hline $1963 / 1964$ & 16.248 .738 & 45,9 & 35.419 .920 \\
\hline $1964 / 1965$ & 17.851 .442 & 44,7 & 39.926 .958 \\
\hline $1965 / 1966$ & 27.797 .101 & 55,4 & 50.176 .739 \\
\hline
\end{tabular}

Fonte: Anuários Açucareiros do IAA.

O acesso ao mercado preferencial estadunidense, pela ocasião do embargo comercial a Cuba, reforçava o ímpeto exportador da economia açucareira no início dos anos 1960, estímulo que incentivava a expansão dos canaviais e a pressão sobre os cultivos e a presença de moradores e colonos fixados em "terras de usina”. A consolidação do "processo usineiro" requeria o processo de proletarização e de expulsão de moradores permanentes do meio rural e sua conversão em trabalhadores volantes.

Em 31 de dezembro de 1953, constitui-se a Agro Industrial Amália S.A., associado a um conjunto de fábricas direcionadas à maximização do aproveitamento da matéria prima e dos resíduos industriais da fabricação do açúcar e álcool dentre elas a IMESA, Industria Matarazzo de Embalagens S.A., como se pode visualizar na figura 14. Era, portanto, a indústria de açúcar e álcool que capitaneava todo o processo agroindustrial. 


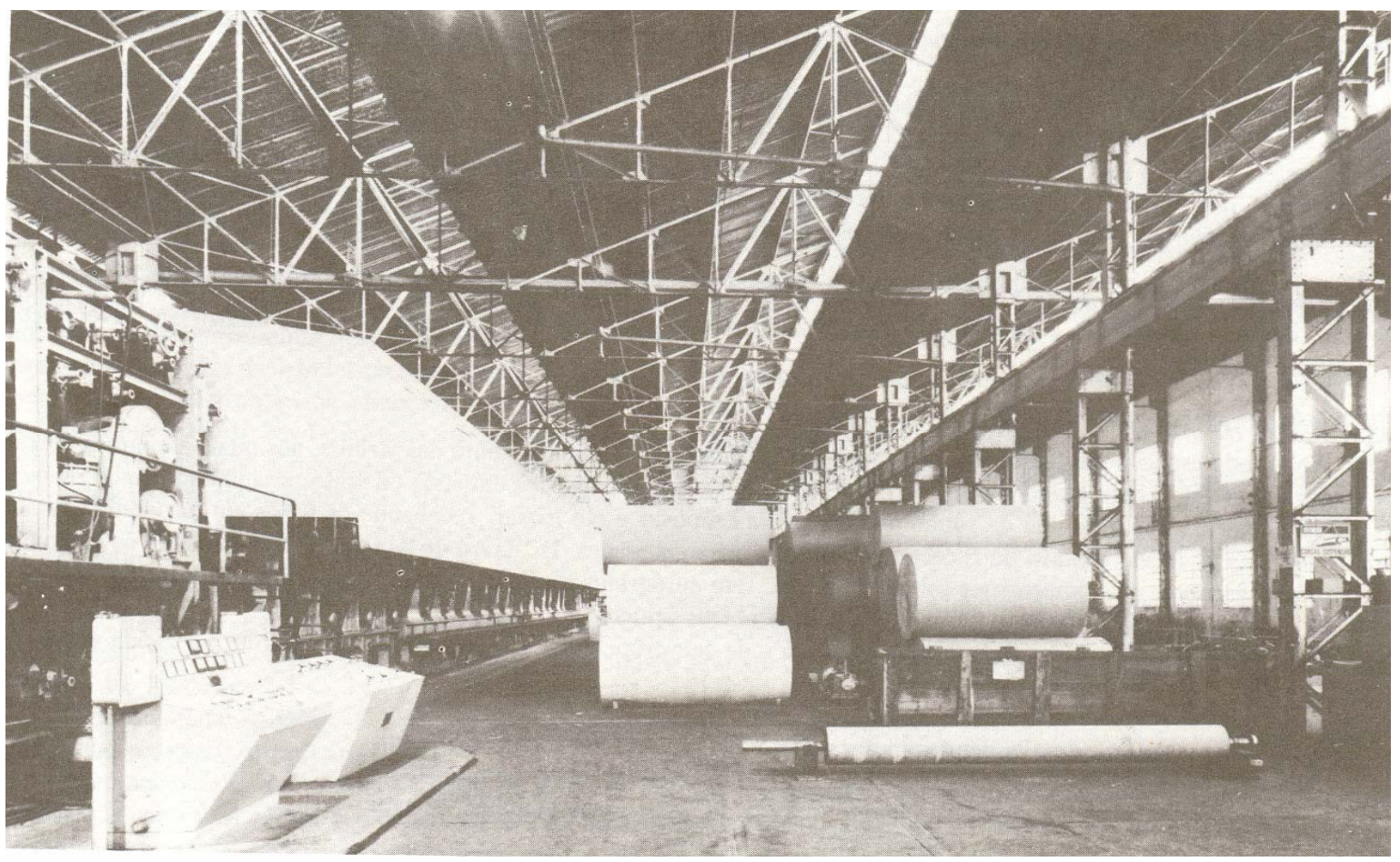

Figura 14 - Integração produtiva em Amália. Fábrica de papel, instalada nas proximidades da Fazenda Amália com a designação de Indústria Matarazzo de Embalagens (IMESA).

Fonte: Matarazzo 100 Anos, s.d., p. 84.

No início dos anos 1960, inicia-se a produção de ácido cítrico anidro na Fazenda Amália, iniciativa esta que ganha força, na década seguinte, com a associação do grupo Matarazzo com a empresa estadunidense Milles Inc. para a produção de ácido cítrico (MATARAZZO 100 ANOS, s. d., p. 148,152).

Outros empreendimentos ${ }^{23}$ das S.A Indústrias Reunidas F. Matarazzo foram feitos, levando-se em conta o contexto desse momento histórico marcado pela tendência crescente de internacionalização da produção industrial e econômica

${ }^{23}$ Como exemplo de novos empreendimentos feitos pelas Indústrias Matarazzo, citemos as joint-ventures estabelecidas pelo grupo familiar com capitais internacionais, desde os anos 1950, como as empresas Milprint do Brasil S.A Indústria e Comércio ( São Caetano do Sul) e a Visking do Brasil S.A Indústria e Comércio (em Ermelino Matarazzo, na capital paulista) (MATARAZZO 100 ANOS, s.d, p. 148). 
brasileira e as instabilidades políticas e tensões econômicas que se sucederam, sobretudo desde a morte do presidente Getúlio Vargas, em agosto de 1954.

De acordo com a publicação “Matarazzo 100 Anos” (s.d., p 148):

Todas essas empresas acrescentavam novos elos do processo de concentração vertical pois complementavam a produção de outras unidades existentes. Apesar de seus resultados positivos nos balanços, a empresa já operava com baixo nível de lucratividade, cercada por competidores cada vez mais agressivos em setores especializados. [...] Como consequência dessa política, de comercilaização mais agressiva dos setores novos da indústria, os ramos tradicionais começaram a enfrentar problemas e o fenônemo se faz sentir particularmente na Indústria têxtil e alimentícia, onde o grupo Matarazzo é forte.

No entanto, a integração vertical e a maximização do uso de insumos industriais e matérias primas no processo produtivo conservaram sua marca entre as empresas de Matarazzo Júnior, de tal maneira que as novas produções industriais (plásticos, química, celulose) salvo algumas exceções, se estabeleceram à sombra das velhas chaminés fabris do grupo familiar.

A prática corrente de maximização da produção industrial das empresas Matarazzo nutria a descentralização produtiva de certos setores industriais da capital paulista, como o do ligado ao beneficiamento do algodão no interior do estado de São Paulo, no decorrer dos anos 1930, como já fora mencionado. A proximidade das fontes de matérias-primas, reduzindo os custos, também tornava vantajosa a localização fora da metrópole paulistana (MATARAZZO 100 ANOS, s.d.,p.123).

Na Fazenda Amália, já haviam sido criadas muitas fábricas e fabriquetas ligadas ao beneficiamento vegetal, sobretudo de frutas (goiaba, marmelo) para a produção de doces - cuja polpa também era fornecida a outras empresas do grupo localizadas na cidade de Campinas -, de molho de tomate e amido de mandioca, aproveitando-se de cultivos agrícolas, feitos na própria Fazenda Amália, que ocupavam uma parcela importante dos colonos, uma vez que o período de safra 
da cultura dominante era menor - estendendo-se a três meses do ano, como era feito até o final da década de 1950, conforme nos coloca Alves (1991, p. 62), ocupando ao máximo a força de trabalho ${ }^{24}$ disponível nas colonias rurais de Amália, como nas plantações de tomate, na figura 15.

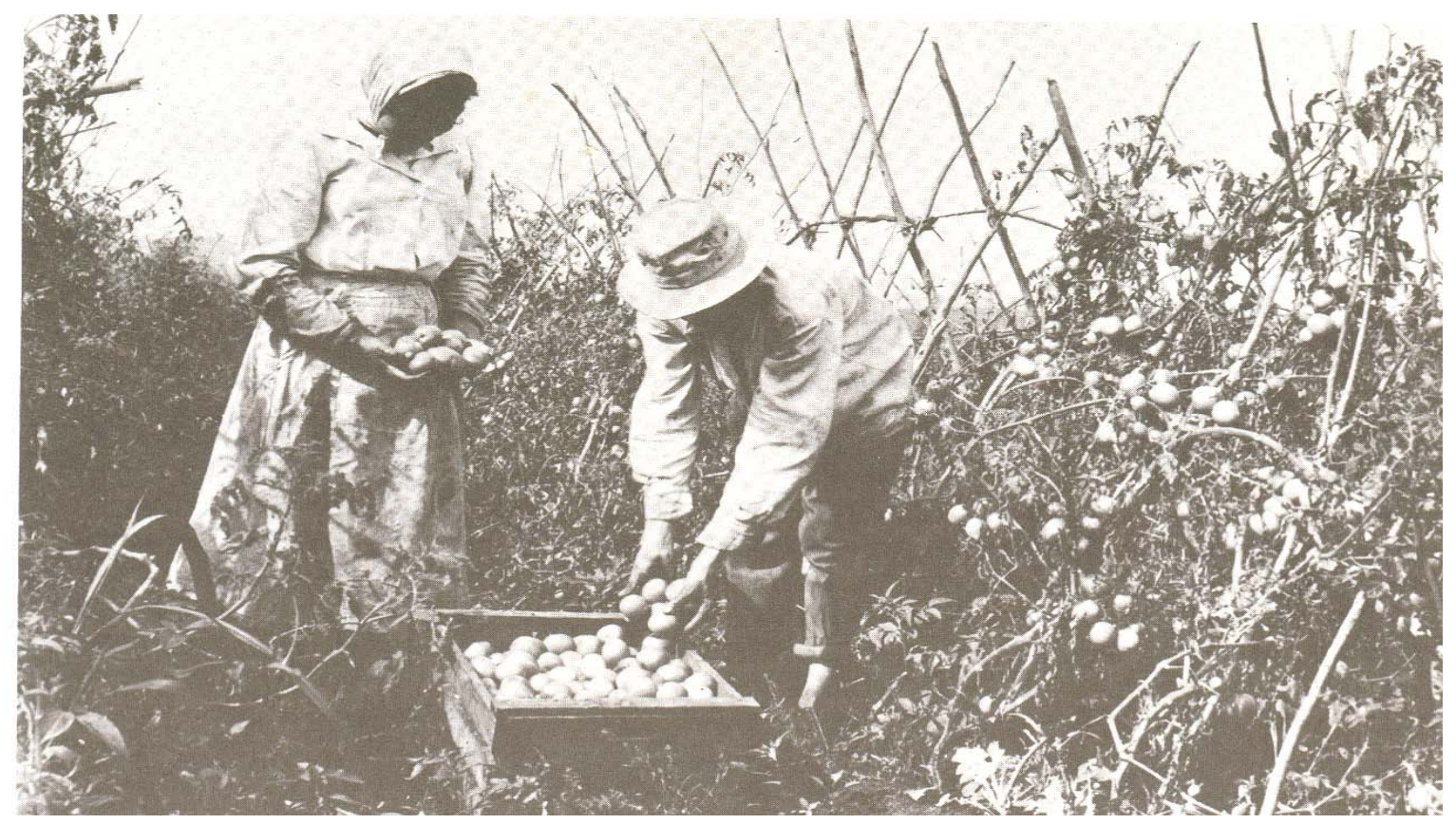

Figura 15 - Trabalhadores colhendo tomates.O fruto era matéria prima para a fabricação de conservas na Fazenda Amália Fonte: Matarazzo 100 Anos, s.d., p. 86.

Além das pequenas fábricas instaladas nas colõnias, foram criadas várias indústrias, como a fábrica de papel, de ácido cítrico e de éter sulfúrico, de óleos e derivados, capitaneadas pela produção agroindustrial canavieira. Assim, a fábrica de papel aproveitava o bagaço da cana, a de ácido cítrico era processada por fermentação alimentada com melaço de cana e a fábrica de éter sulfúrico, aproveitando o excedente de álcool (Matarazzo 100 Anos, s.d, p.83). Estavam

\footnotetext{
${ }^{24}$ A discussão no que tange às relações de trabalho nos canaviais de Matarazzo Júnior será apresentada no tópico em seguida ao exame da produção agroindustrial da fazenda do grupo familiar.
} 
criadas as condições para a constituição de um importante complexo agroindustrial formado por diversas indústrias reunidas em torno da empresa canavieira, ou seja, da Agro Industrial Amália S.A.

Os cultivos de cana-de-açúcar da Fazenda Amália se expandiam seguindo o ritmo de crescimento da lavoura canavieira no estado de São Paulo e no Brasil, neste mesmo período, como podemos refletir a partir dos dados das Tabelas 4.

Os dados fornecidos pelo IAA dão subsídios para o entendimento do processo de territorialização do capital sucroalcooleiro na Fazenda Amália, no estado de São Paulo e no Brasil no período considerado. Por quê?

No tocante à produção canavieira da Usina Amália, é importante ressaltar que ela esteve durante muitas safras nos anos 1950 e 1960, entre as maiores produtoras da gramínea no estado de São Paulo, especialmente nas décadas de 1940 e 1950.

Não podemos desconsiderar que as décadas de 1950 e 1960 envolvem a consolidação do processo usineiro paulista, a racionalização da produção e a constituição de grandes usinas de açúcar e álcool neste estado, proprietária de extensos canaviais.

Distingue-se também a produção canavieira e açucareira de outras usinas pertencentes a grupos usineiros, cuja origem dos capitais era muito diferente daquele que envolvia os capitais aplicados nas primeiras usinas paulistas, há pouco referido. 
Tabela 4

Usina Amália (Safras 1951/1952 - 1965/1966)

Produção canavieira e sucroalcooleira

\begin{tabular}{|c|c|c|c|c|}
\hline Safra & Cana moída (toneladas) & Açúcar (sacos de 60 Kg) & Álcool Hidratado (l) & Álcool Anidro (l) \\
\hline \multirow{3}{*}{ 1951/1952 } & Próprias: $210.458\left(2^{\circ}\right)$ & \multirow{3}{*}{$319.620\left(7^{\circ}.\right)$} & \multirow{3}{*}{$325.941\left(40^{\circ}\right)$} & \multirow{3}{*}{$2.650 .000\left(1^{\circ}\right)$} \\
\hline & Fornecedores: ----- & & & \\
\hline & Total: 210.458 & & & \\
\hline \multirow{3}{*}{ 1952/1953 } & Próprias: $171.871\left(2^{\circ}.\right)$ & \multirow{3}{*}{$293.910\left(10^{\circ}.\right)$} & \multirow{3}{*}{$1.614 .600\left(17^{\circ}\right)$} & \multirow{3}{*}{$917.800\left(6^{0}\right)$} \\
\hline & Fornecedores: ----- & & & \\
\hline & Total: 171.871 & & & \\
\hline \multirow{3}{*}{$1953 / 1954$} & Próprias: ----- & \multirow{3}{*}{$303.350\left(11^{\circ}.\right)$} & \multirow{3}{*}{$352.000\left(52^{0}\right)$} & \multirow{3}{*}{$2.674 .000\left(7^{0}\right)$} \\
\hline & Fornecedores: 200.297 & & & \\
\hline & Total: 200.297 & & & \\
\hline \multirow{3}{*}{ 1954/1955 } & Próprias: $221.231\left(2^{\circ}.\right)$ & \multirow{3}{*}{$350.325\left(10^{\circ}.\right)$} & \multirow{3}{*}{$55.590\left(71^{0}.\right)$} & \multirow{3}{*}{$3.256 .980\left(7^{0}\right)$} \\
\hline & Fornecedores: ----- & & & \\
\hline & Total: 221.231 & & & \\
\hline \multirow{3}{*}{ 1955/1956 } & Próprias: $275.856\left(1^{\circ}\right)$ & \multirow{3}{*}{$430.920\left(4^{\circ}.\right)$} & \multirow{3}{*}{$511.000\left(38^{\circ}\right)$} & \multirow{3}{*}{$3.963 .000\left(3^{\circ}\right)$} \\
\hline & Fornecedores: ----- & & & \\
\hline & Total: 275.856 & & & \\
\hline \multirow{3}{*}{$1956 / 1957$} & Próprias: $251.304\left(1^{\circ}.\right)$ & \multirow{3}{*}{$400.554\left(7^{\circ}.\right)$} & \multirow{3}{*}{$363.000\left(15^{0}\right)$} & \multirow{3}{*}{$2.177 .000\left(8^{\circ}\right)$} \\
\hline & Fornecedores: ----- & & & \\
\hline & Total: 251.304 & & & \\
\hline & Próprias: $298.586\left(2^{\circ}.\right)$ & & & \\
\hline $1957 / 1958$ & Fornecedores: ----- & $497.400\left(6^{\circ}.\right)$ & $1.180 .000\left(15^{\circ}\right)$ & $1.869 .432\left(30^{\circ}\right)$ \\
\hline & Total: 298.586 & & & \\
\hline & Próprias: $335.574\left(2^{\circ}.\right)$ & & & \\
\hline $1958 / 1959$ & Fornecedores: ----- & $543.230\left(12^{\circ}.\right)$ & $2.712 .350\left(51^{\circ}\right)$ & $466.750\left(23^{\circ}\right)$ \\
\hline & Total: 335.574 & & & \\
\hline & Próprias: 266.214(3․) & & & \\
\hline $1959 / 1960$ & Fornecedores: 18.158 & $498.320\left(11^{\circ}.\right)$ & ----- & $2.746 .700\left(28^{\circ}\right)$ \\
\hline & Total: 284.372 & & & \\
\hline & Próprias: $284.634\left(4^{0}\right)$ & & & \\
\hline 1960/1961 & Fornecedores: 24.014 & $536.956\left(10^{\circ}.\right)$ & $2.376 .200\left(22^{0}.\right)$ & $664.500\left(43^{0}\right)$ \\
\hline & Total: 305.560 & & & \\
\hline & Próprias: $303.497\left(2^{\circ}.\right)$ & & & \\
\hline 1961/1962 & Fornecedores: 24.014 & $615.800\left(7^{0}.\right)$ & $2.490 .000\left(12^{0}.\right)$ & $569.130\left(45^{\circ}.\right)$ \\
\hline & Total: 327.511 & & & \\
\hline & Próprias: $248.410\left(5^{0}.\right)$ & & & \\
\hline 1962/1963 & Fornecedores: 25.116 & $468.170\left(12^{0}.\right)$ & $2.427 .000\left(20^{\circ}.\right)$ & $380.380\left(23^{\circ}.\right)$ \\
\hline & Total: 273.526 & & & \\
\hline & Próprias: $284.896\left(3^{\circ}.\right)$ & & & \\
\hline $1963 / 1964$ & Fornecedores: 27.177 & $576.378\left(6^{0}\right)$ & $3.668 .800\left(14^{0}.\right)$ & $251.570\left(32^{\circ}.\right)$ \\
\hline & Total: 312.073 & & & \\
\hline & Próprias: $275.628\left(4^{\circ}.\right)$ & & & \\
\hline $1964 / 1965$ & Fornecedores: 28.242 & $527.950\left(10^{\circ}.\right)$ & $2.293 .800\left(23^{\circ}.\right)$ & 1.066.000 $\left(13^{\mathrm{o}}.\right)$ \\
\hline & Total: 303.870 & & & \\
\hline & Próprias: $337.026\left(4^{0}.\right)$ & & & \\
\hline $1965 / 1966$ & Fornecedores: 74.323 & $730.411\left(17^{0}.\right)$ & $1.001 .000\left(43^{\circ}.\right)$ & $4.691 .000\left(18^{\circ}.\right)$ \\
\hline & Total: 411.349 & & & \\
\hline
\end{tabular}

Fonte: Anuário Açucareiro do IAA. Safras 1953/1954, 1954/1955, 1955/1956; Anuário Açucareiro 1961 (Safras 1956/1957 1959/1960) e Anuário Açucareiro 1967 (Safras de 1960/1961 - 1965/1966)

Obs: Os ordinais entre parênteses representam a posição da produção de açúcar e álcool da Usina Amália em relação ao conjunto da produção açucareira do estado de São Paulo. No que se refere à cana moída o número entre parênteses indica a posição do consumo de matérias-primas próprias no processo de produção industrial. 
Os principais grupos usineiros paulistas, envolviam sobretudo, empresas familiares constituídas por imigrantes, muitos dos quais ingressos no país na condição de colonos, adquirindo, em momentos favoráveis, a propriedade da terra e o acesso ao meio técnico indispensável para o alavancamento da produção canavieira. Estamos nos referindo, sobretudo, aos grupos familiares Ometto, Irmãos Biagi, Zillo-Lorenzetti, Marchesi, Balbo e Dedini ${ }^{25}$ voltados ao setor sucroalcooleiro.

A Usina Amália reduzia a sua participação na produção total de açúcar no conjunto do estado de São Paulo (de 7,9\%, no período de 1941/1942 a 1945/1946, para 4,7\%, no período de 1946/1947 a 1950/1951, e 3,1\%, no período de 1951/1952 a 1955/1956), mas se manteve, durante todo esse período, entre os cinco maiores proprietários estaduais de cana-de-açúcar, sendo que, em algumas safras, foi o maior, segundo os dados revelados por Ramos (1983, p. 74, 80).

A produção canavieira de muitas usinas paulistas, de acordo com os dados do IAA, era superior à produção da Usina Amália, no entanto, parte significativa das canas processadas era oriunda de fornecedores, como no caso das usinas Tamoio, Da Barra, São Martinho e São João entre as safras 1955/1956 e 1959/1960, que, juntamente com a agroindústria dos Matarazzo, constituíam as cinco maiores usinas produtoras de cana do estado de São Paulo ${ }^{26}$.

25 Para mais informações sobre a constituição dos grandes grupos usineiros paulistas ler, Ramos (1983, p. 50-104) e Ramos (1999, p.128-139, 159-170), obras já referidas neste trabalho. Já sobre a constituição do grupo Ometto ler: GORDINHO, Margarida Cintra. Os Ometto. São Paulo: Ed. C. H. Knapp; 1986. Sobre o grupo Biagi, ler: BIAGI, Luiz Lacerda. A Família Biagi: Os Primeiros Cem Anos (1888-1988). Ribeirão Preto: Laserprint Editorial, 1987.

${ }^{26}$ Até a safra 1959/1960, não foi registrada, nos números do IAA, a produção dos fornecedores de cana-de-açúcar para a Usina Amália. RAMOS (1999, p. 143) aponta as burlas das usinas para driblar as limitações de produção impostas pelo IAA, como a constituição de fornecedores de cana que nada mais eram do que uma empresa agropecuária da própria usina. No que concerne aos dados da Usina Amália, ler Silva (2006, p. 25). 
A intensificação da política de erradicação do café, entre 1962 e 1967, estimulou o estabelecimento de relações capitalistas no campo paulista por meio dos processos de expulsão de trabalhadores permanentes, muitos dos quais vinculados ao regime do colonato, e a adoção de técnicas de capitalização da produção, exigindo mão-de-obra pouco numerosa.

Os cafezais paulistas foram em grande parte substituídos por pastagens e lavouras de algodão, milho, arroz, feijão e cana-de-açúcar. Na região administrativa de Ribeirão Preto, onde se encontra a Fazenda Amália, uma parte importante dos pés de café já vinham sendo substituídos pela cultura canavieira por volta da década de 1940, conforme nos revela Ianni (1984, p.45), no que se refere ao município de Sertãozinho, hoje, o maior município canavieiro do estado de São Paulo.

A expansão da cultura canavieira também se deu também graças à concessão de financiamentos às usinas de açúcar pelo IBC-GERCA (Instituto Brasileiro de Café - Grupo Executivo de Racionalização da Cafeicultura), no Centro-Sul, visando à implantação das mesmas nas áreas cafeicultoras, livrandose dos cafezais antieconômicos e oferecendo quotas de produção dessas usinas para os fazendeiros de café. (SZMRECSÁNYI, 1979, p.267).

Estava em marcha o processo de “modernização conservadora” no campo, e em particular na agroindústria canavieira brasileira. De acordo com Ianni (1984, p. 95):

[...] Trata-se de um capital agrário e industrial que continuamente se articula e rearticula no sentido da concentração-centralização, no sentido do crescente aumento da composição orgânica do capital. Esse processo é, em boa parte, organizado e incentivado pela ação governamental. Nesse processo, o proletariado, na usina e no canavial, vê crescer apenas o poder do usineiro e do governo.

Na qual, segundo o mesmo autor:

[...] As modificações da produção, portanto, exigem alterações qualitativas nas relações entre os homens. Na agricultura 
brasileira, elas afetam a empresa agrícola em seus componentes fundamentais, transformando pouco a pouco o fazendeiro em capitalista, o capataz em gerente, o lavrador em proletário (IANNI, 1984, p.115).

Concordamos com as afirmações de Ianni (1984) supracitadas, na medida em que a consolidação do processo de territorialização da agroindústria canavieira e das grandes usinas no estado de São Paulo e no Brasil estava associada aos processos de expropriação, expulsão e proletarização dos moradores permanentes nas "terras de usina", constituindo a face perversa da “modernização conservadora” do campo neste país.

Os moradores das colônias rurais da Fazenda Amália não escaparam a este processo. Processo amargo, violento, doloroso, deixando marcas visíveis, subterrâneas, duradouras, comprometendo o futuro de muitos dos descendentes desses “órfãos de Amália”, conforme Silva (2001, p.69). É o que explanaremos no item a frente.

\subsection{No interior dos canaviais: as colônias de trabalhadores rurais.}

As relações de trabalho, geralmente associadas à lavoura de café, foram ajustadas à produção canavieira desde os tempos da Fazenda London.

A transferência da Fazenda Amália para o grupo Matarazzo, marcou de forma definitiva um processo de erradicação dos cafezais e incentivo à especialização canavieira, tendo, como grande base de produção, a Fazenda Amália, e, como relação de trabalho predominante, o sistema do colonato.

As colônias de trabalhadores existiam em várias seções rurais da fazenda, eram dispersas e distantes umas das outras, reunindo uma considerável parcela da força-de-trabalho do campo, e da população total do município da sede, ou seja, de Santa Rosa de Viterbo, como podemos ver o documento na página seguinte. 
Tabela 5 
O documento supracitado (Tabela 5) fornece vários elementos para pensarmos as relações espaciais estabelecidas entre a colônia-sede materialização do poder das S.A.I.R.F.M. - e as demais colônias rurais, que reuniam a maior parte dos trabalhadores. O controle sobre a quantidade de casas, o número de pessoas adultas e menores e a ocupação de trabalho preocupavam a administração da fazenda.

Outrossim, o registro mostra que a maior parte da população residente nas seções da Fazenda Amália se encontrava nos municípios de Santa Rosa de Viterbo (49,9\%), São Simão (20,7\%), Cajuru (19,8\%), Santa Cruz da Esperança (3,8\%), Serra Azul (2,9\%) e Tambau (2,3\%).

Com mais de 9.182 residentes nas colônias das 18 seções de Amália, os trabalhadores da fazenda Amália representavam parcela importante do conjunto da população de vários municípios onde se estendiam os domínios territoriais do grupo Matarazzo, principalmente o de Santa Rosa de Viterbo.

Nele, 4.638 pessoas moravam e trabalhavam nas seções da Fazenda Amália - representada pelas colônias das seções Santa Sofia, Sede, Fazendinha e Bananal - das quais $1.771(19,8 \%)$ habitavam a colônia-sede.

Tomando esses dados em comparação com a população total do município de Santa Rosa de Viterbo, registrada pelo Censo Demográfico de 1960, podemos constatar que a população das colônias da Fazenda Amália representavam cerca de 73,4\% da população rural do município, abrigando, nesse período, a maior parte da população total do município de Santa Rosa de Viterbo (43,2\%).

Os dados do documento apresentado revelam uma significativa participação da população residente nas colônias de Amália no conjunto da população total do município de Santa Rosa de Viterbo e da população rural no município, possuindo, inclusive um contingente humano superior à população urbana desse período, que se encontrava em torno de 4.411 habitantes. 
Tabela 6

Município de Santa Rosa de Viterbo - SP

População Urbana, Rural e das Seções da Fazenda Amália.

Início da década de 1960

\begin{tabular}{|c|c|c|c|}
\hline \multirow{2}{*}{$\begin{array}{c}\text { População } \\
\text { Urbana }\end{array}$} & \multicolumn{2}{|c|}{ População rural } & População \\
& $\begin{array}{c}\text { Colônias da F. } \\
\text { Amália }\end{array}$ & Total & \\
\hline 4.411 & 4.638 & 6.316 & 10.727 \\
$(41,1 \%)$ & $(43,25 \%)$ & $(58,9 \%)$ & $(100 \%)$ \\
\hline
\end{tabular}

Fonte: Fundação Cultural de Santa Rosa de Viterbo.

IBGE, Censo Demográfico de 1960.

As colônias da Fazenda Amália, segundo o registro pesquisado na Fundação Cultural de Santa Rosa de Viterbo (Tabelas 5 e 6) abrigavam 73,4\% da população rural do município, apesar de a colônia-sede dispor de uma série de atividades econômicas (sobretudo comerciais, como armazéns, farmácia, depois também, um supermercado, e serviços, como hotel, para funcionários do grupo Matarazzo, de passagem pela fazenda, a trabalho, como se pode ver na figura 17), culturais (cinema, salão de festas; vide figura 16), educacionais (escolas), recreativas (clube de campo e jogos de futebol, sobretudo aos domingos na colônia-sede) e hospitalares ${ }^{27}$, que em muitos casos, inexistia ou existia de modo precário na sede do município.

\footnotetext{
27 "Havia quatro escolinhas rurais isoladas funcionando em duas salas anexas ao velho cinema. Uma quinta foi criada e instalada em uma pequena sala na Colônia Branca”. Em 1942, o prédio foi cedido pela Fazenda Amália à Secretaria Estadual de Educação, sendo criado a nova unidade escolar, por decreto publicado em 17 de dezembro de 1942 (Cf. "EEPG Fazenda Amália” 1942-1992 - 50 anos. P.4-6). Para mais informações sobre a Escola Estadual da Fazenda Amália, consultar a dissertação de mestrado defendida recentemente por Islan Reinaldo da Costa, intitulada "O Grupo Escolar da Fazenda Amália: contribuições para a história da instituição entre 1942 e 1966” pela Pontifícia Universidade Católica de São Paulo. Já o Hospital Santo André, construído no início dos anos 40, na sede da Fazenda Amália, foi muito importante para a população residente na cidade de Santa Rosa de Viterbo, uma vez que não havia ainda um congênere no núcleo urbano nesse período. Um hospital só foi construído na sede do município em meados da década de 1960 (ANTUNES, 2006, p.38). Foi comunicada no final de 2001 no hebdomadário local (FIM de linha para o Santo André? $O$ Jornalzão, Santa Rosa de Viterbo, Ano 8, $\mathrm{n}^{0}$ 305, p. 1, 17 nov. 2001) a demolição do
} 


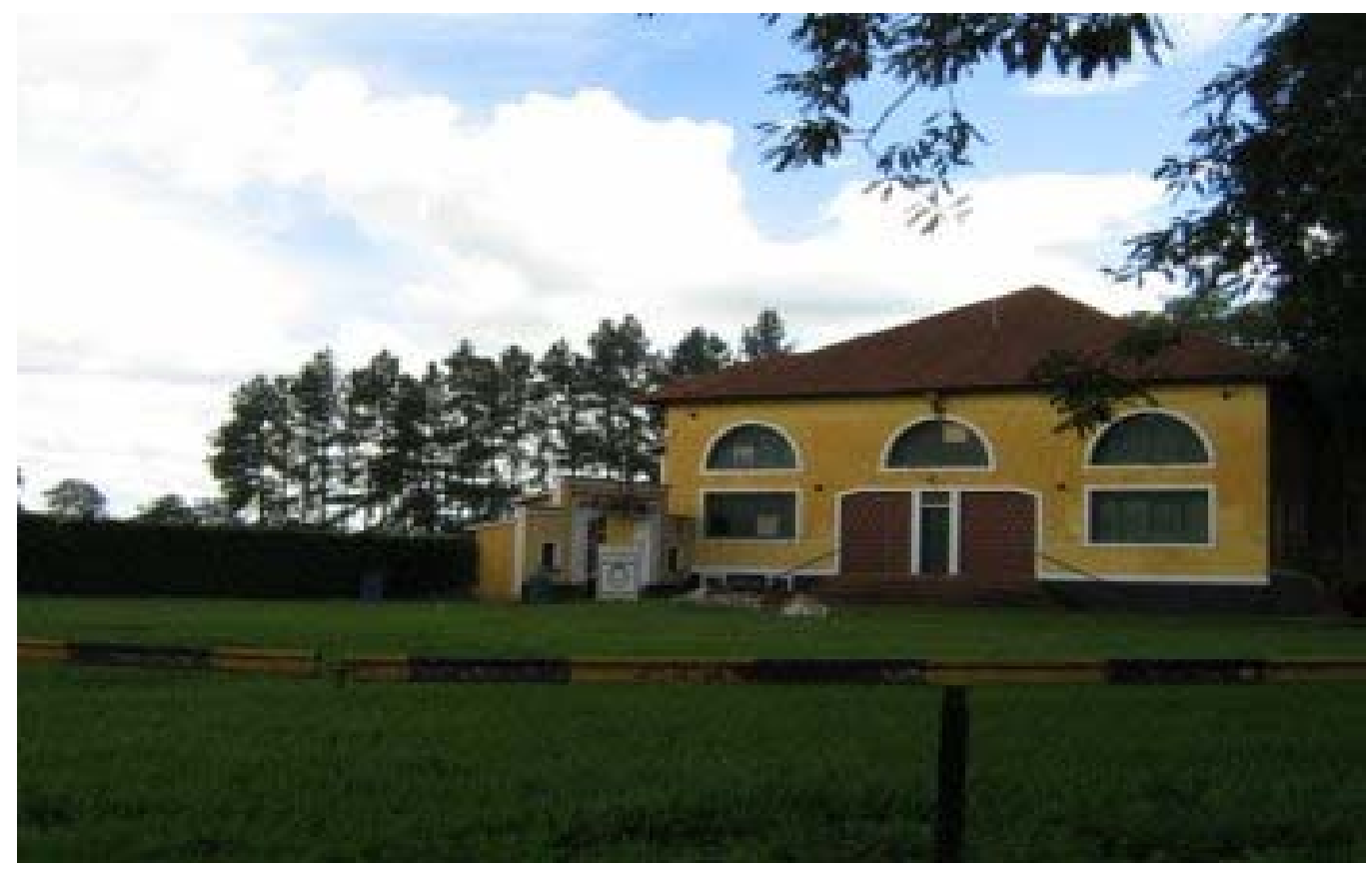

Figura 16 -: Antigo Cine Dom Joanico. Fotografia de 2006

Disponível em: <http://www.estacoesferroviarias.com.br> Acesso em 21 abr. 2007

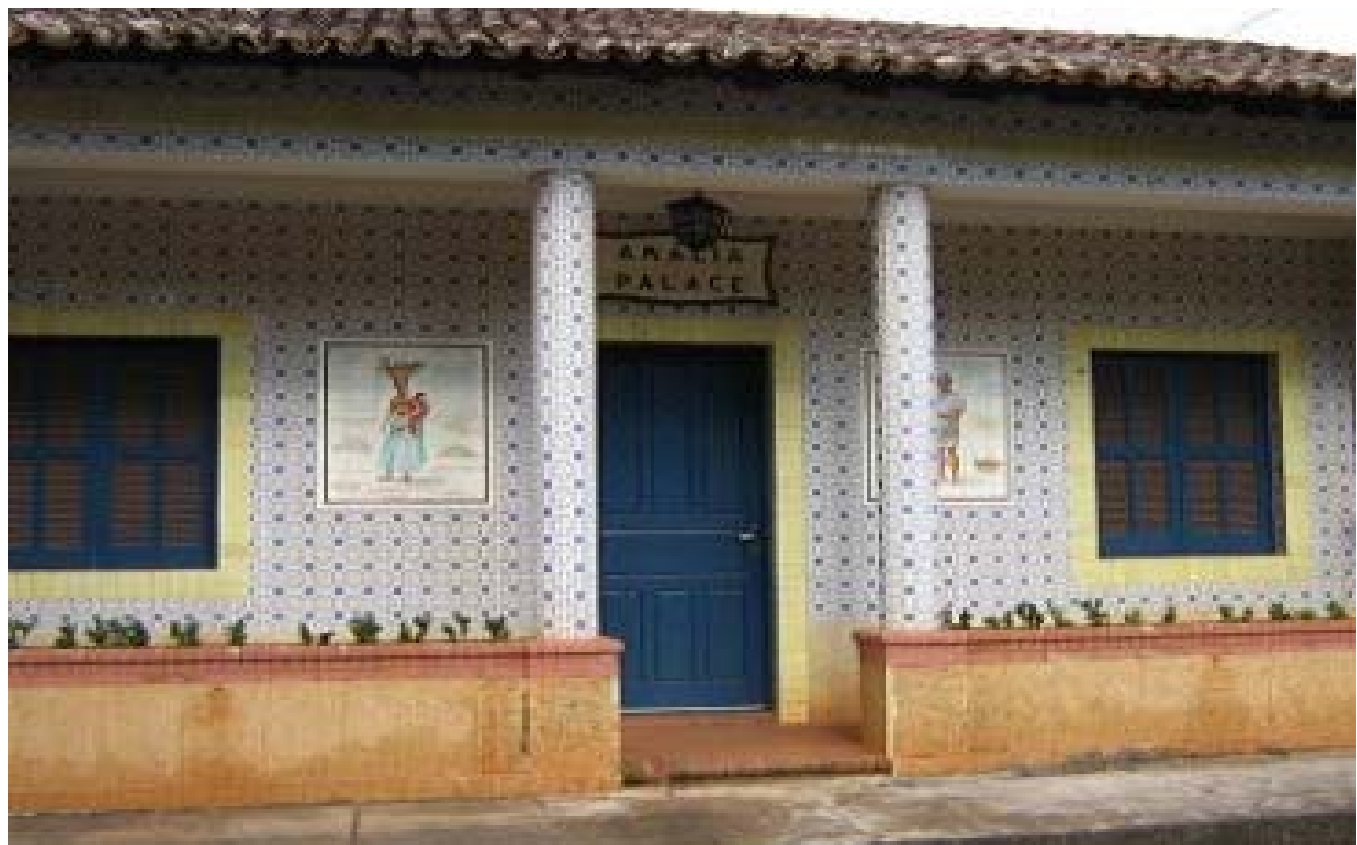

Figura 17 - Amália Palace.O hotel recebia principalmente funcionários qualificados das empresas do grupo Matarazzo, de passagem a trabalho pela Fazenda Amália. Fotografia de 2006.

Disponível em: <http://www.estacoesferroviarias.com.br> Acesso em 21 abr. 2007

prédio do hospital da Fazenda Amália, fato confirmado em muitas das entrevistas feitas para esta pesquisa. 
Os trabalhadores da produção canavieira e d núcleo fabril da Fazenda Amália moravam em casas cedidas pelos Matarazzo, em colônias espalhadas pelo latifúndio canavieiro. Já os funcionários da usina, ligados aos cargos administrativos, habitavam em casas melhores, construídas na colônia-sede da empresa pelo grupo Matarazzo.

No entanto, nota-se uma divisão territorial marcante entre os espaços de morada e ocupação dos trabalhadores das colônias daqueles que exerciam cargos de chefia na Fazenda Amália. Os primeiros tinham suas casas distantes, tanto da sede como das outras colônias, enquanto os trabalhadores da administração da usina (que muitas vezes, contava com a direção de um europeu) ${ }^{28}$ se encontravam próximas à usina e ao palacete do grupo familiar, este isolado do restante das construções.

As relações de trabalho que vigoravam no colonato eram assentadas no chamado sistema de titularidade. Por meio deste, o único trabalhador que mantinha um vínculo trabalhista com a empresa era o chefe de família, geralmente o homem (mesmo que toda a família se dedicasse à produção, como na "ajuda" das mulheres e das crianças) (SILVA, 2001, p. 64). Desse modo, o trabalho dos demais membros da família era computado ao título do pai, como revela o depoimento de um ex-colono da Fazenda Amália abaixo:

Comecei a trabalhar com oito anos, oito anos, não era assim fichado, mas ajudava os pais. Naquele tempo não tinha moleza não, Nossa Senhora. Naquele tempo, os pais levavam pra roça, em que às vezes caia geada, então os Matarazzo usavam fazer fogo, assim, a fogueira, pra espalhar a geada, e ai meu pai me levava. Ali, quando chegava em casa, assim os pé já estavam que nem uma pedra, de tanto frio que fazia [...] Então tinha uma planta que eles plantavam chamava tum, né? Então, a rua tinha sete metros assim de espaço. Então eu ficava ali, com uma

${ }^{28}$ Com destaque para o italiano Guido Maranca, já mencionado (diretor de Amália, a partir de 1947) e os neerlandeses Fock (diretor da usina) e Van Pren (diretor agrícola) que chegaram na Fazenda em novembro de 1952. (ANTUNES, 2000, P. 20 e 143) 
enxadinha ali ajudando os meus pais, né? Não tinha moleza não. Eu nem estudei quase [...] Ajudavam [os irmãos]. Todo mundo movimentava. Pegou uma idadinha que podia com uma enxadinha, não sendo uma enxada grande; a gente cavava uma enxadinha lá e ia para a roça. [...] E aí quando acabava a colheita de cana então entrava a plantação de cana, né? Nóis era molecote, então aí nóis ia catar, limpar a cana pra modo de poder picar e plantar, ficava aquele mundo de cana cortada pra poder plantar. Então estava sempre movimentando, né? (Excolono da Fazendinha, $3^{\mathrm{a}}$. Seção da Fazenda Amália. Depoimento colhido em 16 ago.2005)

O sistema de titularidade que vigorava nas relações de trabalho, nas colônias da Fazenda Amália, estava em consonância com o processo de organização do trabalho existente nas colônias de café paulistas, onde o processo de organização do trabalho era comandado e controlado pelo chefe de família ou o pai-marido-patrão conforme Silva, 1999, p. xx) .Este, além de submeter o trabalho familiar, como chefe de família e chefe de trabalho, personificava a unidade do trabalho de todos os membros da família, já que o trabalho dos colonos não era individualizado.

A autoridade do pai-marido que também se faz patrão é reflexo de um poder masculino que perpassava todo o tecido social e era legitimada socialmente e concretamente por meio do sistema de titularidade, já que, em geral, o homem era o único trabalhador amparado por um vínculo empregatício com os proprietários da fazenda (SILVA, 2001, p. 64).

A mediação dos colonos com o patrão se expressava abstratamente por meio do recebimento do pagamento pelo colono, chefe de família e o comandante do trabalho coletivo da mesma, sinalizando as tarefas a serem desempenhadas por cada membro, assim como o conjunto de normas e valores, reforçando a autoridade masculina.

Essa dominação era materializada concretamente por meio do espaço de cada um no interior da unidade de trabalho, no interior da morada e da família, como pudemos comprovar na fala de um ex-colono de família que, desde 
“molecote”, já “ajudava” o pai, que já “pegou uma idadinha que podia com uma enxadinha” e “ia para a roça”, “movimentando” a família, colaborando produtivamente para esta enquanto unidade de trabalho coletivo.

No que se refere à Fazenda Amália, essa dominação fazia-se sentir por meio de um rígido controle sobre as colônias de trabalhadores, o seu número de moradores, sobre sua divisão sexual e etária, variável importante para se dimensionar a quantidade e a produção de corpos voltados para o labor nas atividades econômicas desenvolvidas pelo grupo familiar naquelas terras, como se pode constatar por meio da análise do documento, expresso na Tabela 5.

Ainda no tocante a relação entre a população das colônias rurais e o número de trabalhadores, observamos que dos 9.182 moradores que residiam e trabalhavam, apenas 3.176 eram ocupados em atividades laborativas, no início da década de 1960. Esse dado reforça a importância do sistema de titulação no encobrimento da exploração e da dominação no espaço produtivo, que envolvia o esforço de todos os membros da família assim que “podia com uma enxadinha”. Também dissimula a participação do trabalho da mulher e das filhas na esfera doméstica, papel fundamental no espaço da morada na reprodução da força de trabalho do marido-pai-patrão que trabalhava e dos filhos que ajudavam assim que “pegasse uma idadinha”.

Não raro, essas mulheres (mãe-esposa) também se empregavam em tarefas produtivas, seja na lavoura de cana ou de outros produtos cultivados na fazenda, ou na "roça da família” próxima à morada ou em áreas de brejo e terrenos pouco férteis liberadas para culturas que se destinavam, sobretudo ao consumo familiar:

Trabalhei. Desde criança eu trabalhava na Amália. Eu fui criada lá, na Fazendinha. Meu pai quando mudou, eu era pequena, tinha uns sete anos, oito. Eu sempre trabalhei na roça, só que depois eu não fui trabalhar mais, começou a doer uma perna minha, então aquela dor aqui. Desgaste dos dois lados.Então dava aquela dor, e ai pegava esses joelhos de vez em quando aqui da perna, não agüentava mais trabalhar. Tinha que ficar 
com uma perna na frente, tinha serviço para carpir, pra ficar agachado pra eu cortar cana. (Ex- colona da seção Fazendinha. Depoimento colhido em 16 ago. 2005)

Ah, eu trabalhava que nem os outros mesmo, né. Só que depois a minha mãe deixou eu em casa porque tinha os irmãos pequeno, né? Tinha uma irmã doente, aí eu ficava mais em casa e ela trabalhava, mas eu trabalhava em casa. Eu não trabalhava na lavoura assim, mas trabalhava em casa, porque precisava olhar as crianças. [...] Aí depois fomos tudo se formando, se formando, as coisas já foi mudando e aí a minha mãe logo fez nóis casar tudo. Quando ele [o pai] foi embora, largou da minha mãe, o meu irmão mais velho [...]tinha oito anos. [ pausa] Eu era mais nova do que ele. [...] Era título da minha mãe. Trabalhava para ela. Era tudo dependente dela.(Ex-colona da seção Bananal. Depoimento colhido em 16 ago. 2005).

Esses dois depoimentos ressaltam as várias esferas da participação do trabalho feminino, que muitas se dava de uma forma extremamente desgastante, tanto no espaço produtivo como no espaço da morada. No primeiro deles, apontamos o trabalho precoce, com grande dispêndio de energia e força física para quem logo cedo já não “agüentava mais trabalhar”. O segundo depoimento revela duas faces do trabalho da mulher: o trabalho da mãe na lavoura, tornada precocemente chefe de família, mas detentora do título de seu trabalho, poder até então personificado na figura masculina, do marido-patrão.

Contudo, a mãe necessitava da "ajuda” da filha que "não trabalhava na lavoura, mas trabalhava em casa, porque precisava olhar as crianças”, convicção da jornada de trabalho que extrapolava a esfera produtiva no campo. Esta fala também revela a lógica da reprodução da unidade familiar no sistema do colonato: “Aí depois fomos tudo se formando, se formando, as coisas já foi mudando e aí a minha mãe logo fez nóis casar tudo”: a multiplicação do trabalho da família na terra.

A exploração no trabalho era escamoteada por meio do sistema de titularidade e do trabalho feminino na esfera doméstica, permitindo a reprodução da família enquanto força de trabalho para os canaviais do Conde Matarazzo 
Júnior, mas não só na lavoura da gramínea como nas outras plantações feitas nas seções da fazenda.

Uma outra forma de mascarar a superexploração nas relações de trabalho era a permissão de cultivos agrícolas e criação de pequenos animais domésticos.

Contudo, em muitos casos, pode-se registrar o repúdio inabalável do Conde Matarazzo Júnior frente aos pedidos constantes de concessão de pequenos lotes de terra para a provisão dos trabalhadores nas colônias, feitos pelos diretores da Usina Amália (ANTUNES, 2000, p. 163). Mesmo assim, tratava-se de terras menos férteis ou inadequadas para a cultura canavieira, como brejos, além da permissão de plantar no “quintal”, espaço próximo à morada nas colônias. Nas palavras de um entrevistado:

Meu pai plantava feijão, arroz, milho, sabe? Tudo plantava. Tinha sempre porco lá, que engordava, criava galinha, tudo né? Tinha tudo isso. [...] Então, eles [os Matarazzo] davam assim aqueles lugar que não dava pra plantá cana, eles deixavam planta [...] Ah, tinha lugar que era longe. Tinha que lá ajudar. Tinha que limpar tudo no braço, né? Aí prantava arroz, colhia, e quando colhia tinha que dar um pouquinho: assim de quatro partes como se diz, dava uma para a Amália, né? [...] Depois, às vezes, até deixava plantar no meio da cana, sabe. Deixavam. Plantava milho, feijão. Então, não tem as ruas de cana? Nóis prantava no meio. Enquanto ela tava novinha dava o tempo do feijão .É ás vezes ela tava alta. Ás vezes a cana tava bem alta e sempre tinha que catar tudo quannto arrancava e carregar nas costas até na estrada, né? Era milho, era feijão. Eles deixavam prantá (Ex-colona da Seção Fazendinha depois também assalariada sazona até 1987. Depoimento colhido em 4 ago. 2005).

Com a promulgação da Lei $n^{0}$. 4.914, de 2 de março de 1963, discorrendo sobre o Estatuto do Trabalhador Rural, equiparam-se os direitos do trabalhador rural ao urbano, passando os primeiros a dispor de uma série de direitos acessíveis naquele momento apenas aos empregados urbanos, desde a implantação da CLT (Consolidação das Leis do Trabalho) no Estado Novo. A 
extensão das normas trabalhistas ao campo e o fim do sistema de titularidade geram temores ao grupo familiar quanto à possibilidade da reivindicação de terras por parte dos colonos, principalmente os trabalhadores canavieiros da Fazenda Amália.

A administração da usina já vinha implementando novas medidas de controle sobre os trabalhadores rurais, como a ameaça da cobrança de aluguel (ANTUNES, 2000, p. 163), cujo cálculo era baseado na quantidade de integrantes da família, controle este revelado por meio de um documento (Tabela 5) da Fazenda Amália fazendo referência precisamente à quantidade de casas e colonos que até então moravam e trabalhavam nas terras da família Matarazzo, como atesta a data assinalada no registro: 23 de agosto de 1963, há quase seis meses da promulgação do Estatuto do Trabalhador Rural.

Na região de Ribeirão Preto, efervescia uma série de mobilizações populares no campo, antes mesmo do derradeiro abril de 1964 (WELCH \& GERALDO, 1992). Todo esse movimento histórico precedia a "greve” de $1966^{29}$.

Ocorrido entre os dias 29 de outubro e 5 de novembro de 1966, essa "greve” foi articulada pela direção da usina (que controlava até o recém criado Sindicato dos Trabalhadores das Indústrias de Alimentação de Santa Rosa de Viterbo), conforme depoimentos de ex-funcionários colhidos por Silva (2001, p.67).

Segundo Silva (2006, p.1), a expulsão dos colonos da Fazenda Amália “dentro da lei e da ordem” foi amparada por instrumentos políticos da empresa e

${ }^{29}$ Estas considerações são baseadas no projeto de pesquisa coordenada pela professora Dra. Maria Aparecida de Moraes Silva, intitulado "Mulheres da Cana: Memórias", financiado pela Fapesp, que analisando a trajetória de vida de 70 homens e mulheres que passaram pelos canaviais de Amália, assim como 208 processos trabalhistas e depoimentos de juizes que julgaram essas ações, analisou um período que se estende da década de 1930 até o final dos anos 1990. Os resultados de tal trabalho ainda estão sendo organizados pela autora, e se encontram parcialmente publicados na Revista Pesquisa Fapesp N ${ }^{0}$. 61, e no artigo “Greve na Fazenda”, já referido, fontes consultadas pelo pesquisador e constitui uma base importante para o entendimento deste contexto histórico,necessário para a compreensão da desagregação do colonato,do sistema de titularidade e a expansão do trabalho volante em nossa região de estudo. 
os representantes da ditadura militar: a greve foi um mero pretexto para justificar a expulsão, sem o pagamento dos direitos aos trabalhadores e a rescisão do contrato de trabalho (SILVA, 2006, p.15).

A permanência de muitos colonos nas casas da seção durante o período de tramitação dos processos, sem poder trabalhar, os muitos anos de espera para a solução judicial, mesmo esta, no final, sendo favorável ao trabalhador rural, a “mixaria” dos acordos feitos com os trabalhadores que não agüentaram esperar ou não quiseram acionar a justiça do trabalho, as perseguições aos familiares e a negação de empregos a pessoas que possuíam membros da família que justamente acionaram o aparelho jurídico para reivindicar seus direitos; o silêncio e a recusa, estratégias de resistência e que marcam toda uma vida, inclusive comprometendo as gerações futuras, com a negação de oportunidades de trabalho, não pode ser negligenciada e compreendida de forma despercebida em nossas reflexões sobre o processo de territorialização da agroindústria canavieira na Fazenda Amália. (SILVA, 2006).

Silva (2006) constatou a utilização de amparos legais· instituídos pelo golpe militar (Lei de Greve por parte dos proprietários da usina para findar com as colônias de trabalhadores nas terras da Fazenda Amália. Em $1^{\circ}$ de agosto de 1966 é fundada a S.A. Santa Rosa de Produtos e Trabalho Agro Pastoril, empresa criada para explorar a mão de obra dos que trabalhavam nas terras da fazenda Amália, como assinala Antunes (2000, p. 219). Estamos diante de um processo encabeçado pelo grande capital sucroalcooleiro, com o auxílio legal do Estado, patrocinando a substituição dos colonos-trabalhadores rurais, moradores permanentes de terras pertencentes à usina, por trabalhadores assalariados. As colônias de trabalhadores foram desarticuladas, as casas foram destruídas, e hoje se perdem em meio aos canaviais. Vide as figuras 18 e 19 


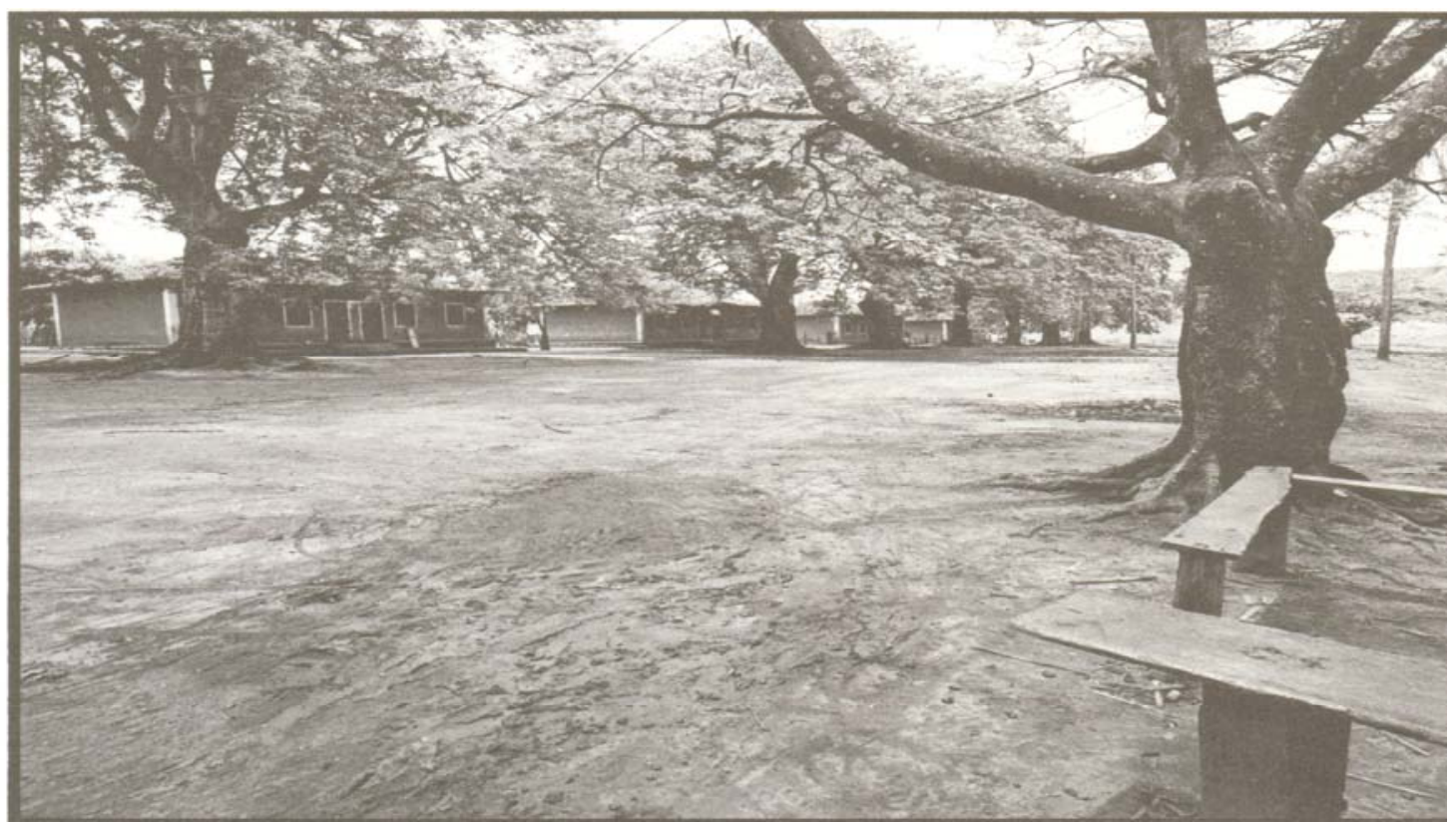

Figura 18 - Colônia de Alambari, no município de Cajuru - SP.Esta foi uma das últimas colônias de trabalhadores rurais, a ser desarticulada pelo Grupo Matarazzo, no final dos anos 1980.

Fonte: Matarazzo 100 Anos, s.d., p.101.

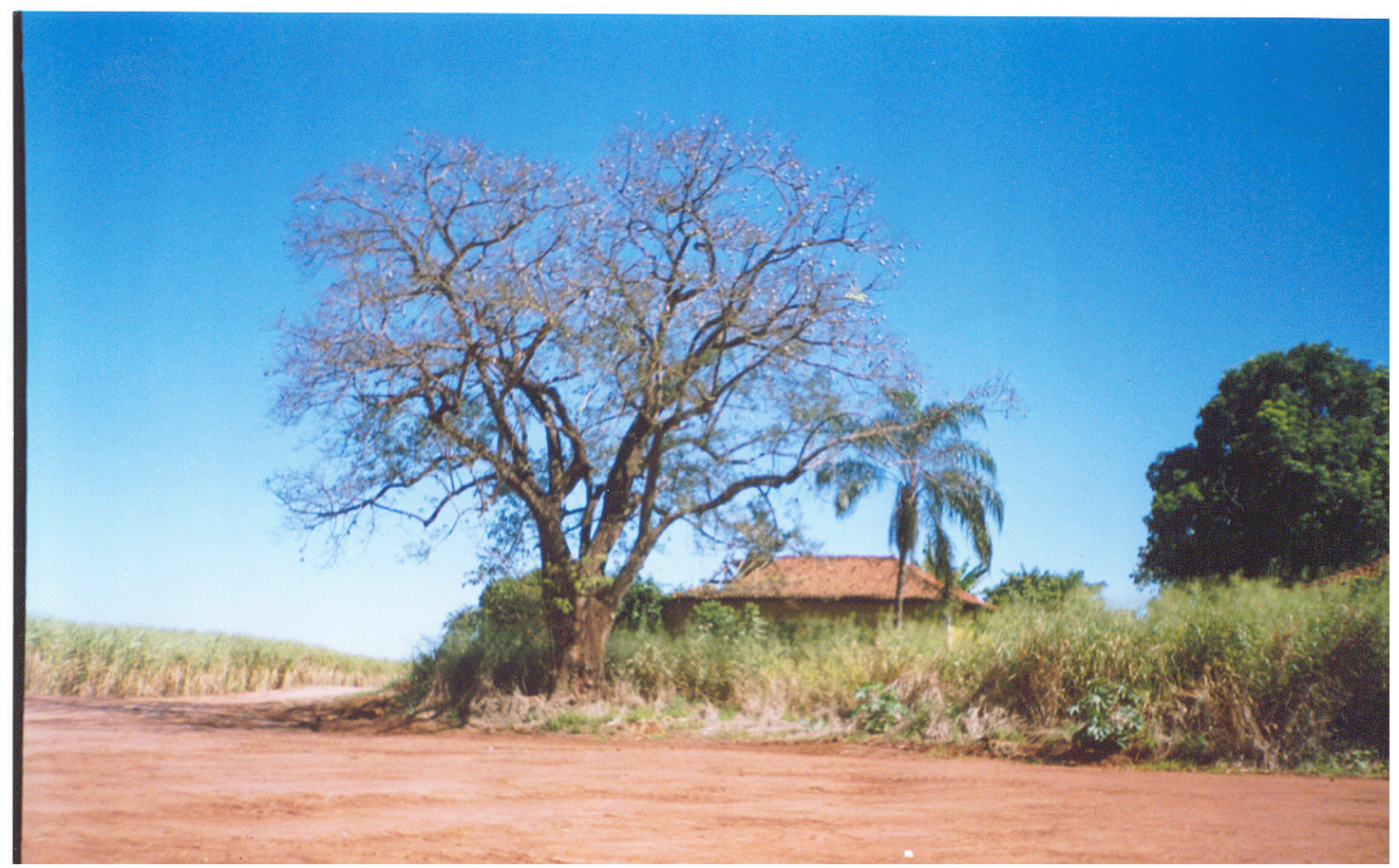

Figura 19 - Saudades de Alambari. No detalhe, casa do administrador da colônia, abandonada.

(Autor: André Eduardo Ribeiro da Silva, 23 jun. 2003). 
São memórias mutiladas, hoje violentamente registradas por milhares de trabalhadores: são as dores físicas no corpo; as aposentadorias precoces por invalidez; auxílios-doença; a vontade em muitos deles de voltar ao campo; a vida dura na cidade, sem muitas ofertas de emprego.

Para grande parte destes trabalhadores restou migrar para um lugar onde a vida de sua família não pudesse mais uma vez ser interrompida, muito distante das influências do grupo Matarazzo (SILVA, 2001, p. 68,70).

A violência material e simbólica, que acompanhou esse processo de expulsão dos colonos e de “formatação do bóia-fria” e marca registrada do processo de modernização da agricultura brasileira, foi estudado por Silva (1999), sendo de fundamental importância, pois permite uma leitura para além das dimensões econômicas do dito processo de modernização da agricultura e proletarização do trabalhador rural, em que o seu entendimento fazer-se-ia unicamente à luz de uma concepção conflitiva entre capital e trabalho.

Esse modo de entender a realidade, apesar de muito importante, não se mostra de todo descolado de outros elementos que, associados, se revelam imprescindíveis para a interpretação, entre eles o conceito de nó, apropriado por Silva (1999, p. 20) ao explicitar as relações entre a modernização trágica e os processos de exploração-dominação, por meio das vertentes de classe, gênero e raça-etnia.

Segundo a mesma autora:

Esta postura teórico-analítica permite, mutadis mutandis, a compreensão da multiplicidade, das diferenças, das especificidades destas relações. E mais. Permite a percepção da maneira pela qual os diferentes agentes da dominação apóiam-se uns sobre os outros, negam-se entre si ou se reforçam mutuamente (SILVA, 2006, p.16-7).

As reflexões de Silva permitem uma leitura mais densa e relacional das diferentes esferas imbuídas no processo de “modernização conservadora” da 
agricultura brasileira, em particular da canavieira no estado de São Paulo. Leitura que extrapola à de muitos teóricos cujos estudos ficaram muito detidos em uma perspectiva econômica do mundo, desassociada das relações sociais. Estamos nos referindo principalmente aos estudiosos da modernização da agricultura brasileira e, em particular, da consolidação dos complexos agroindustriais nas décadas de 1970 e 1980, centrados na lógica de desenvolvimento do capitalismo no campo brasileiro, sem considerar as variáveis abordadas por Silva (1999) ou os conflitos e a violência, marca registrada e legitimada desse processo de territorialização do capital na agricultura brasileira, presente nas pesquisas de Oliveira (1997).

Estas abordagens se mostram fundamentais para o entendimento das bases em que se constituiu o processo de territorialização da agricultura canavieira neste país e, em particular, na Fazenda Amália, no nordeste paulista, territorializando o grande capital sucroalcooleiro e permitindo a reprodução de suas desigualdades de forma violenta no campo e na cidade, acentuada com a formatação do assalariado sazonal, sobretudo com a utilização crescente do trabalhador migrante, sobretudo das regiões pobres do Vale do Jequitinhonha e de alguns estados nordestinos. É o que também desvelaremos no capítulo seguinte. 


\section{A Territorialização da Agroindústria Canavieira nas décadas e 1970 e 1980 e a formatação do "bóia-fria” nas terras do Conde Matarazzo Jr.}




\section{1 - Seguindo a cartilha da "modernização conservadora"}

O contexto em que se consolidou, no Brasil, o projeto de desenvolvimento capitalista no campo, sobretudo a partir de meados da década de 1960, é designado por vários autores como um processo de "modernização conservadora", "dolorosa”, "trágica”; organizado em torno de grandes empresas rurais, detentoras de grandes domínios territoriais e comprometidas com o suporte técnico-científico da "Revolução Verde" e de acordo com os interesses de uma classe de latifundiários e do empresariado, base de apoio político aos generais militares que governavam o país desde o golpe de Estado civil-militar de 1964, conforme aponta Martins (1984, p. 33):

É que o encaminhamento da questão fundiária, pela ditadura militar, não podia fazer-se separadamente da questão do desenvolvimento econômico, inclusive do desenvolvimento da agropecuária, entendidos como o fortalecimento da grande empresa capitalista e sua expansão.

Segundo Martins, a intervenção militar na esfera agrária brasileira se efetivou por meio de dois processos: a expansão da empresa capitalista e o “esvaziamento" político do campo, muitas vezes amparado por um arcabouço jurídico-legal que regia em nome da segurança nacional.

Portanto, o modelo vencedor de desenvolvimento agrário brasileiro passa a se calcar na promoção, a todo custo, do pleno funcionamento das engrenagens capitalistas da economia brasileira, garantida à base de facilidades creditícias, de financiamentos e de subsídios ao grande capital ao processo de industrialização do campo, consolidando uma estrutura econômica e social capitalista no campo, ancorada principalmente na constituição dos chamados complexos agroindustriais, objeto de estudo de muitos pesquisadores da agricultura brasileira nas décadas de 1970 e 1980, principalmente. 
Esse processo favoreceu a articulação e, em parte, a confusão entre os interesses de latifundiários e representantes do grande empresariado nacional e internacional, por um lado, patrocinado pelo Estado autoritário, por meio de políticas estatais voltadas à expansão da industrialização do campo; por outro, também, incentivado por um espesso e acelerado movimento migratório do campo em direção às metrópoles e grandes centros urbanos do país, que se procedeu em múltiplas escalas no interior do território brasileiro.

O tempo do capital, de acordo com a lógica da "modernização conservadora”, se fazia necessário, sendo fundamental adequar a lógica de desenvolvimento agrário brasileira à lógica do capitalismo mundial, embora muitas vezes tratasse de uma lógica ancorada na "produção de relações não capitalistas de produção”, lógica capturada e essencial para o processo de reprodução de um padrão de acumulação capitalista no campo brasileiro.

Nos estudos geográficos, Oliveira (1999, p. 74 -5) nos fornece uma leitura do processo do desenvolvimento da agricultura capitalista no Brasil com o processo de desenvolvimento contraditório e combinado do capitalismo mundial, produzindo um território ancorado em bases essencialmente capitalistas, ou não, por meio da reprodução territorial de práticas e de um modo de vida camponeses, ou melhor, a partir da monopolização de frações territoriais ao padrão de reprodução do capital.

É por meio dessas considerações de Oliveira (1999) que buscamos entender o processo de territorialização do capital no interior da agricultura brasileira e sobremodo a intensificação de sua articulação e mesmo fusão com determinados setores industriais, promovendo a ampliação da produção e diversificação do parque industrial brasileiro, voltado para as "necessidades" da agricultura, por meio da difusão territorial das agroindústrias: unidades processadoras de matérias-primas agrícolas e de produção e extensivamente consumidora de insumos industriais.

Materializam-se amplos domínios territoriais, comandados pela produção de matérias-primas agroindustriais e culturas para exportação, 
expressa a partir da intensificação da incorporação do progresso técnico e intensificação de relações de trabalho baseadas no assalariamento sazonal no campo.

Espacialmente, o desenvolvimento da agricultura capitalista concretizou-se por meio da expansão da monocultura, principalmente da cultura canavieira, dos pomares de laranja e das plantações de soja etc, que se somou à dominação histórica legitimada por novo aporte ideológico dos grandes proprietários de terra e grupos econômicos nacionais e internacionais em amplas porções do território brasileiro.

Vários autores propuseram uma leitura desse processo (MULLER, 1989 e GRAZIANO DA SILVA, 1981, entre outros) a partir da constituição dos complexos agroindustriais, numa dimensão econômica a partir da lógica e do desenvolvimento do grande capital na agricultura brasileira, sem se pautar, no entanto, no entendimento das relações sociais produzidas no decorrer do processo de “modernização conservadora”, como expõe Silva (1999, p.63).

Essa leitura do processo foi muito referida à dinâmica da agroindústria sucroalcooleira, considerada, por muitos pesquisadores, um modelo explicativo de tal lógica de desenvolvimento para o campo brasileiro.

No entanto, muitos pesquisadores se preocuparam em analisar o processo de modernização do campo brasileiro, ressaltando um outro viés explicativo, assentado na agudização das desigualdades sociais e da legitimação “pela lei e pela ordem” de múltiplas formas de violência, marca registrada desse processo de desenvolvimento no campo brasileiro, ao qual se referem vários dos autores supracitados.

No que se reporta ao setor sucroalcooleiro no Brasil, já durante a década de 1960, o Instituto do Açúcar e do Álcool ${ }^{1}$ toma uma série de iniciativas com o intuito de expandir a capacidade instalada das usinas,

\footnotetext{
${ }^{1}$ Para melhor explicação do surgimento e da ação dessa entidade estatal na regulação do setor sucroalcooleiro do Brasil, ver: SZMRECSÁNYI, Tamás. O Planejamento da Agroindústria Canavieira do Brasil (1930-1975) São Paulo: HucitecUnicamp,1979
} 
permitir a concentração/centralização do capital agroindustrial canavieiro e planejamento do setor com o intento de aumentar a capacidade produtiva das usinas para a produção de excedentes para o mercado interno e externo, sendo este último principalmente em decorrência das possibilidades de ingresso no mercado preferencial estadunidense com a conflagração da Revolução Cubana e o posterior embargo econômico imposto pelos Estados Unidos a este país, aumentando as possibilidades de ingresso das exportações brasileiras, no mercado preferencial estadunidense.

Esse contexto foi acompanhado por inovações no campo técnico e no processo de trabalho colaboraram para o desenvolvimento da agroindústria canavieira. Com o aumento do número de usinas e a necessidade de assistência a elas, dinamizou-se o desenvolvimento das indústrias de bens de produção voltadas para o reparo e constituição de equipamentos destinados ao processamento de açúcar e álcool, voltadas para o mercado interno e especialmente ao estado de São Paulo, com destaque para a Dedini, de Piracicaba e a Zanini, sediada em Sertãozinho, fundamentais no processo de expansão da agroindústria canavieira paulista, em particular durante a vigência do Proalcool, nas décadas de 1970 e 1980. De acordo com Ramos (1999, p.33): "São Paulo contava com uma fabricação local de equipamentos adequada ao tamanho de seu parque fabril em constituição.

Alterações na lavoura canavieira, como a introdução da queimada, a expansão do assalariamento na agricultura, a mudança do sistema de corte de cana de três para cinco ruas, a adoção de técnicas de capitalização da produção, como o uso da carregadeira mecânica (vide figura 20), principalmente a partir da década de 1960, e, posteriormente da colheitadeira (início dos anos 1980), provocaram incremento e concentração da produção (ALVES,1991, p.77-8). 


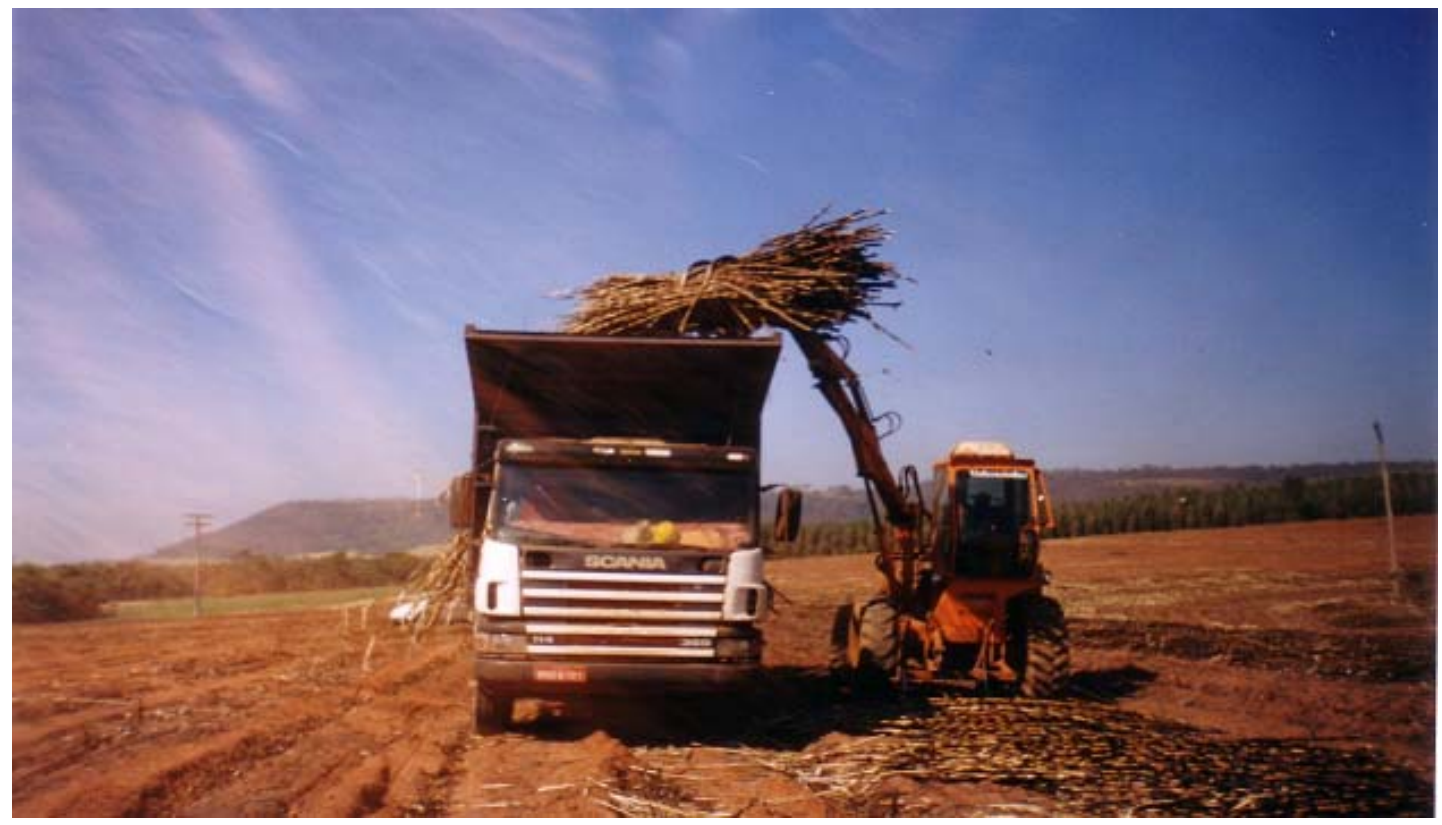

Figura 20 - Caminhão e carregadeira mecânica da Usina Santa Rita, no município de Santa Rosa de Viterbo.

(Autor: André Eduardo Ribeiro da Silva, setembro de 2006).

Também surgiu o PLANALSUCAR (Programa Nacional de Melhoramento da cana-de-açúcar), em 1971, cuja eficácia estava associada a outros projetos do IAA, com a finalidade de coordenar e executar os projetos de pesquisa, não só no que diz respeito à matéria-prima, mas também à racionalização da produção (incentivo à fusão de usinas, nacionalização das empresas agroindustriais canavieiras e construção de terminais açucareiros nos portos de exportação do produto), atuando por meio “do uso de variedades com poder genético mais elevado de produção, mais resistente às enfermidades e com alta resposta aos fertilizantes” (SZMRECSÁNYI, 1979, p.412).

A pesquisa e a introdução de novas variedades da gramínea no campo produtivo, em muito, influirão no aumento do aproveitamento agrícola e agroindustrial da produção canavieira, com reflexos também sentidos na organização do trabalho nos talhões de cana: o aumento da produtividade do trabalho se fez com a crescente depreciação dos salários pagos aos trabalhadores canavieiros, ritmo de trabalho que se fez acompanhar da morte 
de 19 cortadores desde a safra de 2004/2005, no estado de São Paulo, como exporemos mais adiante neste trabalho.

Desta forma, várias práticas foram adotadas para sanar os pontos de estrangulamento da agroindústria canavieira brasileira e implementação de políticas de exportação do açúcar. O Programa de Apoio à Agroindústria Canavieira, criado em 1973, objetivava o financiamento para a compra e o arrendamento de terras, de equipamentos, e para a absorção de quotas de produção de outras usinas, sustentada pelo Fundo Especial de Exportações, fonte de volumosos recursos oriundos da exportação do açúcar a preços compensadores no início dos anos 1970.

Em novembro de 1975, em resposta à brusca diminuição dos preços do açúcar no mercado internacional, nasce o Proálcool (Programa Nacional do Álcool), “a menina dos olhos” da agroindústria canavieira, a partir de 1975 até o início da década de 1990.

O Proálcool, de modo simplificado, pode ser dividido em três etapas: a primeira fase, que se estendeu de 1975 a 1979, a segunda fase que foi de 1980 até 1984, e a última etapa que se alongou de 1985 a 1990.

A primeira fase do Proálcool foi uma “válvula de escape” para o setor sucroalcooleiro, visto que seu início coincide com a retração do preço do açúcar no mercado internacional. Por meio do programa, verificou-se um crescimento na área cultivada de cana, bem como na capacidade de produção das destilarias anexas (junto às usinas de açúcar), com financiamento - por pressão dos usineiros - para eliminar a capacidade ociosa das mesmas.

A implantação da segunda fase do Proálcool (1980 -1984) coincide com o “Segundo Choque do Petróleo”, sendo que, nesta ocasião, ele se constitui como uma “alternativa energética” (produção de álcool para fins carburantes), articulando acordos com a indústria automobilística, bem como de empresas de bens de produção do setor. Neste período, nota-se um aumento no número de destilarias autônomas e na área cultivada, principalmente a expansão da cultura canavieira em áreas não tradicionais de cultivo do produto (Paraná, 
Goiás, Mato Grosso e oeste de São Paulo²), notadamente no Centro-Sul do país. Este grande aumento da área cultivada, associado ao descompasso entre a produção e o consumo interno, entre outros, viabilizou, em certos períodos, a exportação do produto, principalmente o álcool anidro combustível e o hidratado neutro, o primeiro com destino aos mercados estadunidense e europeu, o segundo voltado ao mercado japonês.

A diminuição dos incentivos governamentais, influenciada pela crise fiscal e o endividamento do Estado brasileiro, agudizada no final da década de 1980, assim como a alteração do contexto internacional da produção de petróleo, com a diminuição da cotação dos preços do barril de petróleo no mercado internacional e a descoberta e exploração de reservas do hidrocarboneto na Bacia de Campos, pela Petrobrás, marcaram a terceira fase do Proálcool até a extinção do programa no início dos anos 1990.

O questionamento do álcool como opção energética, inclusive por parte da Petrobrás, era reforçado pela escassez do produto no mercado interno, com o desabastecimento ${ }^{3}$ em todo o país, no início da safra 1989/1990. (BACCARIN, 2005, p. 20).

Fica evidente este pacto entre usineiros e o governo, que foi responsável por toda sorte de subsídios e injeção de recursos durante toda a duração do programa. Seus resultados ainda são discutidos e o governo alega que o aumento dos recursos é superior aos subsídios concedidos ao setor sucroalcooleiro, expressos por meio da “conta álcool” e “conta governo”:

Instaura-se também o mito de que o PROALCOOL foi responsável por amenizar o saldo da balança comercial

\footnotetext{
${ }^{2}$ No oeste paulista, a expansão da canavicultura foi incentivada pelo PRO-OESTE. Trata-se de um grande projeto articulado pelo governo paulista para ampliar a lavoura canavieira no oeste do estado a partir da criação de destilarias autônomas, produtoras de álcool, com recursos do PROÁLCOOL. Boa parte dos proprietários de destilarias autônomas eram tradicionais famílias de fazendeiros de gado na região.

${ }^{3}$ Para mais informações ver a reportagem na Revista Veja “Um sonho corroído”. São Paulo, 24 de maio de 1989, p. 102-10.
} 
brasileira: diminuindo as importações de petróleo (o álcool substituiu apenas um derivado de petróleo - gasolina - e até em muitos casos provocou um aumento na produção desta, como a verificada em 1984, onde o país exportou quatro bilhões de litros de gasolina a preços baixos). O mesmo argumento vem se referindo a baixa participação dos subsídios em relação até a outros produtos como o trigo, por exemplo. (THOMAZ JR., 1988, p.165)

O que fica patente, mais uma vez, é a perpetuação histórica do pacto concretizado entre usineiros e o Estado, por meio de políticas estatais voltadas ao setor sucroalcooleiro, responsável por toda sorte de subsídios e injeção de recursos públicos, atuando a concentração fundiária e a precarização do trabalho e da vida de muitos trabalhadores nos canaviais brasileiros:

Assim, o Estado, ao sintetizar no seu interior as contradições capital-capital e capital-trabalho, aponta alternativas concretas através da "modernização conservadora" da agricultura para o setor sucro-alcooleiro. Na prática, oferece as condições materiais para a rentabilidade do capital, assegurando orientação clara no sentido de subsumir toda a terra disponível, inclusive o latifúndio, conservando, pois, o poder político - econômico da burguesia agrária, agora no comando das atividades agrícolas e fabris sucro-alcooleiras (THOMAZ JR., 2002, p. 84).

Deve-se ressaltar a continuidade das condições necessárias para a exploração do território em bases monopolísticas, ou seja, o usineiro capitalista-empresário industrial é também grande proprietário de terras, sendo responsável pela maior parte da produção da matéria-prima consumida no processo produtivo.

No início da década de 1990, as reformas federais neoliberais do governo Collor de Mello prenunciavam a extinção de vários órgãos públicos, entre eles, o Instituto do Açúcar e do álcool, por meio da medida provisória $\mathrm{N}^{0}$. 151, de 15 de março de 1990, norma que posteriormente também foi estendida ao Proálcool. 
Com os ventos neoliberais de Collor de Mello, as condições de mercado tenderam a aumentar a sua influência no desempenho do setor sucroalcooleiro, rumo a um processo que muitos autores consideram ser uma desregulamentação do setor sucroalcooleiro, mas cujos desdobramentos Baccarin (2005, p.27) afirma se tratar de uma nova regulamentação voltada à agroindústria canavieira.

Para Baccarin (2005), a nova regulamentação do setor sucroalcooleiro, gestada durante a década de 1990, deve-se à continuidade de muitos dos amparos estatais que há muito vêm sendo destinados aos produtores de cana, açúcar e álcool deste país.

Segundo o autor, o processo de desregulamentação do setor sucroalcooleiro não alterou a essência das políticas de proteção governamental ao setor sucroalcooleiro, pelo contrário, reforçou-as segundo as conveniências nesse momento determinado.

O capital sucroalcooleiro seguia o padrão de reprodução ampliada, incorporando novos elementos a seu discurso, como o referencial ambiental, utilizando-se da sua estrutura produtiva e gerencial, e apresentando-se à sociedade como símbolo de um Brasil moderno, produtivo, no plano das aparências. Concomitantemente, acelerava-se, no campo, o processo de proletarização massiva de trabalhadores e a intensificação da precarização do trabalho nos talhões de cana. É o que explanaremos a seguir.

\section{2 - A intensificação do assalariamento sazonal e da "cidade da usina”}

Os trabalhadores rurais assalariados no campo brasileiro foram foco de preocupação de vários estudiosos da agricultura brasileira, mediante um processo histórico de intensificação da modernização no campo, acompanhada por uma espessa migração campo-cidade e aceleração do crescimento populacional urbano, nas quatro últimas décadas do século $\mathrm{XX}$. Neste 
contexto, milhões de trabalhadores rurais foram expropriados de suas unidades familiares ou expulsos das fazendas, muitas vezes retornando ao mundo rural de uma forma desconcertante: não na antiga condição de pequenos proprietários de terra, parceiros, rendeiros, moradores ou outras formas de perceber-se enquanto camponês, mas como sujeitos sociais das transformações em curso, relegados à venda de sua força de trabalho e impingidos pelo processo de proletarização.

Os colonos da Fazenda Amália, expulsos da grande propriedade na segunda metade da década de 1960, foram obrigados a transferir-se para o núcleo urbano, principalmente para a cidade de Santa Rosa de Viterbo, cuja população urbana foi quintuplicada nas quatro últimas décadas do século XX. Veja a Tabela 7.

Tabela 7

Santa Rosa de Viterbo - SP

População Urbana e Rural (1940 - 2000)

\begin{tabular}{|c|c|c|c|c|c|}
\hline Ano & $\begin{array}{c}\text { População } \\
\text { Urbana }\end{array}$ & Em \% & $\begin{array}{c}\text { População } \\
\text { Rural }\end{array}$ & Em \% & População Total \\
\hline 1940 & 1.795 & 19,5 & 7.400 & 80,5 & 9.195 \\
\hline 1950 & 2.761 & 26,7 & 7.567 & 73,3 & 10.328 \\
\hline 1960 & 4.411 & 41,1 & 6.316 & 58,9 & 10.727 \\
\hline 1970 & 6.861 & 58 & 4.974 & 42 & 11.835 \\
\hline 1980 & 11.666 & 80,4 & 2.846 & 19,6 & 14.512 \\
\hline 1991 & 17.534 & 91,3 & 1.661 & 8,7 & 19.195 \\
\hline 2000 & 20.196 & 94,2 & 1.239 & 5,8 & 21.435 \\
\hline
\end{tabular}

Fonte: IBGE .Censos Demográficos de 1940, 1950, 1960, 1970, 1980, 1991 e 2000.

Muitos desses “órfãos de Amália” continuaram dedicando-se ao trabalho nos canaviais da Usina Amália, agora sob o intermédio de empreiteiros, recebendo um salário individual pelo trabalho no eito da cana. 
Contudo, os trabalhadores rurais não guardavam mais a condição de colonos, moradores permanentes do meio rural, mas a condição de assalariados sazonais, empregados apenas durante a safra da gramínea e residente na cidade, sobretudo numa cidade específica, produzida para abrigar e reproduzir essa força de trabalho.

Na cidade de Santa Rosa de Viterbo, os bairros e vilas surgidos ou criados na periferia urbana, eram compostos em sua maior parte por excolonos e trabalhadores volantes da usina da família Matarazzo.

O espaço reprodutivo desses trabalhadores de Amália, portanto, estava distante do espaço produtivo, na Fazenda Amália, e do convívio social daqueles que se afirmavam como os moradores da cidade. A segregação sócioespacial foi recriada no meio rural e urbano, a partir da intensificação do trabalho volante nos canaviais, nutrindo estigmas e afetando a identidade social e a percepção desse trabalhador rural, como aponta Silva (1999), no que tange à materialização do processo de proletarização no espaço das cidades e nos canaviais da região de Ribeirão Preto.

O “direito à cidade” não abrangia todos os seus moradores, especialmente os ex-colonos, expulsos da Fazenda Amália, reduzidos muitas vezes a uma cidadania abreviada, a uma condição de "bóia-fria"4.

Para Silva, (2004, p. 33-4):

O bóia-fria, além de ter sido banido da legislação, não é sequer considerado trabalhador, pois não é permanente, logo não possui direitos. Bóia-fria é uma palavra que engloba significados depreciativos e humilhantes. Arrancam-lhe não somente a roça, os animais, os instrumentos de trabalho. Desenraizam-no. Retiram-lhe, sobretudo, a identidade

\footnotetext{
${ }^{4}$ Sobre a discussão da divisão sócio-espacial reproduzida com a intensificação do assalariamento sazonal na lavoura canavieira na cidade e no local de trabalho, fortalecendo os estigmas e imagens depreciativas sobre os trabalhadores volantes, ler os trabalhos de Silva já mencionados e a dissertação da socióloga Andréa Vettorassi, intitulada "Espaços Divididos e Silenciados: um estudo sobre as relações sociais entre nativos e os "de fora" de uma cidade do interior paulista”, defendida, em 2006, na Universidade Federal de São Carlos.
} 
cultural, negando-lhe a condição de trabalhador. É transformado em ninguém, portanto, em nada, dado que sua condição de trabalho passou a não ter reconhecimento nem legal, nem social. Esta foi a situação experimentada por milhares de trabalhadores em diferentes partes do país, sobretudo no estado de São Paulo, local privilegiado para a instalação do modelo modernizador da ditadura militar.

Cabe ainda destacar as reflexões de Rossini (1988), principalmente no que reporta à individualização do trabalho rural com a desintegração do colonato nos canaviais paulistas e a importância do trabalho feminino na formação da renda familiar.

O trabalho produtivo no campo, na Fazenda Amália” deixava de ser assentado no título e controle do pai-marido com a “ajuda” dos demais membros da família, pensada enquanto unidade de trabalho e que agora passava a depender individualmente de cada trabalhador, minando a ilusão do “provedor”, do chefe de família, e convertendo-a na soma de rendimentos de cada membro da mesma. Conforme Rossini (1988, p. 168):

A unificação do mercado de trabalho rural e urbano leva o volante à alternância de atividades ditas rurais e urbanas. A organização da família, entretanto, pouco se alterou, apenas muda, em parte, a questão da autoridade, pois não é mais o "chefe da família" que determina a atividade a ser desenvolvida pelos componentes da unidade familiar, mas cada um que se organiza em função das oportunidades individuais. A subordinação da mulher ao homem, porém, continua. Há certa unidade no que tange à soma das "rendas" para garantia da sobrevivência miserável. Muito cedo, os jovens deixam de contribuir para a "casa”, participando de um processo de migração ou contraindo matrimônio (Brant, 1977).

[...] a mulher não perdeu autoridade, já que não a tinha, o que na realidade aumentou foram as responsabilidades [...].

As contribuições de Rossini (1988) são interessantes porque permitem uma leitura do espaço e da família que transcende uma orientação marxista de 
cunho mais ortodoxa, calcada exclusivamente numa leitura do mundo a partir da relação contraditória capital e trabalho.

Ela também merece consideração por trazer elementos novos para a discussão nos estudos geográficos dessa problemática, como a incorporação da categoria gênero, também presente no conceito de nó, formada pelas interrelações entre as categorias classe social, gênero e raça-etnia, incorporada por Silva (1999), em suas reflexões sobre os processos de dominação-exploração que acompanharam o desenvolvimento capitalista da agricultura na região de Ribeirão Preto, principal base territorial de suas pesquisas.

Além do violento processo de proletarização a que foram submetidos os sitiantes, parceiros e moradores permanentes “do lugar”, em nosso caso particular, os colonos da Fazenda Amália, o trabalho volante nos canaviais envolveu também a incorporação de sujeitos sociais oriundos das mais diversas regiões do país, em particular de regiões empobrecidas do país, especialmente do Vale do Jequitinhonha, em Minas Gerais, e estados nordestinos.

Muitos desses sujeitos sociais foram atingidos pelo corolário da “modernização conservadora” em seus estados de origem, porém muitos outros resistiam ao processo de proletarização e as mais adversas condições que afetavam o processo de reprodução do trabalho da família na terra, migrando durante o período de maior demanda de trabalho nos canaviais do Centro-Sul e Nordeste.

Os trabalhadores canavieiros migrantes ausentavam-se de seis a sete meses por ano do trabalho, deixando a família na terra, possibilitando, com os parcos salários recebidos, sobretudo no corte da cana, a reprodução da concepção da terra enquanto unidade de trabalho da família camponesa, em seu local de origem.

Vários estudiosos, nas ciências sociais, dedicaram-se à compreensão do processo migratório como a condição fundamental para a reprodução da unidade familiar camponesa na terra, estratégia percebida na ausência- 
presença de parte dos membros da família, extensiva ao longo do ano e da vida dos trabalhadores e de suas famílias.

Não se pretende, neste momento, retomar estes estudos. Cabe, entretanto tecer algumas considerações sobre a dimensão do trabalho migrante no tocante à consolidação do processo de territorialização da agroindústria canavieira.

Martins (1986, p. 45- 59) ao cotejar os processos da reprodução da família camponesa na "terra de trabalho" revela a importância dos movimentos migratórios e a proletarização ao longo de parte do ano e da vida de parte dos seus membros como estratégia de resistência a perda de suas terras e ao processo de proletarização completa a que estão pressionados, condição que reproduz, ainda que de forma precária, a família na terra. Nesse sentido, a migração sazonal e o trabalho da família camponesa reproduz a força de trabalho indispensável para a enorme riqueza das regiões canavieiras deste país.

Silva (1999), em sua trajetória de pesquisas sobre as relações de trabalho nos canaviais paulistas, em particular nos estudos sobre os trabalhadores migrantes da cana, identifica as bases objetivas e subterrâneas que estão por trás do processo de criação e recriação do trabalho volante, muitas vezes envolvendo uma migração temporária permanente, mobilidade precária, vulnerável, miserável. As pesquisas da autora, em nossa área de estudo, revelaram as marcas da violência material e simbólica, efeitos da expulsão das famílias de colonos da Fazenda Amália.

Na mesma trilha, Menezes (2002, p.19) nos apresenta as condições de sociabilidade estabelecidas por cortadores de cana do Agreste paraibano nas regiões de origem e na área canavieira pernambucana, em que as estratégias de recusa, as formas cotidianas de resistência são criadas e reproduzidas em diversas escalas espaciais, ao longo dos itinerários desses sujeitos sociais, por ela designados como camponeses trabalhadores-migrantes.

Os autores mencionados acima nos chamam a atenção pela preocupação com a dimensão espacial do fenômeno migratório e da materialização da 
lógica de reprodução desta agricultura em áreas que extrapolam suas bases territoriais. Consideramos nessa temática de estudo, a importância dada ao conceito geográfico de escala, construindo, desconstruindo e reconstruindo múltiplas relações materializadas no território, que se faz dinâmico e contraditório pelo processo social.

Os efeitos do processo de proletarização se espraiava por diversas escalas espaciais no país, multiplicando seus efeitos sobre a organização da família e da unidade do trabalho familiar.

O processo de proletarização afeta, contudo, tanto as regiões de desenvolvimento capitalista mais avançado no campo, expresso por meio da monocultura da cana-de-açúcar no estado de São Paulo, como em áreas distantes deste centro mais dinâmico, porém igualmente inserida no processo social e territorial de produção da riqueza destas regiões, fornecendo sazonalmente parcela importante da força de trabalho indispensável para a reprodução da lógica do grande capital sucroalcooleiro.

Muitos trabalhadores canavieiros são reduzidos, portanto, a dispêndio de força e energia física para a reprodução das engrenagens capitalistas e a construção territorial da riqueza, perfazendo itinerários migratórios, que longe de serem sazonais ao longo do ano, tem a duração de uma vida inteira. Vida ceifada numa migração temporária, que se faz permanente como revelam Martins (1986), Menezes (2002) e Silva (1999), preocupados com a questão migratória no campo brasileiro, intensificadas, sobretudo, no bojo da “modernização conservadora”.

Entretanto, o processo migratório sazonal não engloba, nos dias de hoje, somente os trabalhadores rurais procedentes dos rincões empobrecidos desse país. Ele envolve também aqueles sujeitos sociais “do lugar”, afetados, sobretudo pela intensificação da mecanização do corte de cana nas duas últimas décadas, como explanaremos no próximo capítulo.

Longe das preocupações deste trabalho está utilizar a exaustão, o aporte teórico metodológico enaltecido pelos autores(ras), contudo gostaríamos de 
destacar a importância desses estudos para uma leitura do mundo calcada em múltiplas dimensões do fenômeno, possibilitando um novo trilhar e novas fontes teóricas nas investigações sobre o processo de proletarização e desenvolvimento do capitalismo no campo brasileiro.

Guiados por estas reflexões, não podemos dissociar em nossa análise, o processo de territorialização da agroindústria canavieira na Fazenda Amália do contexto da proletarização no campo e, conseqüentemente, da marcha da urbanização paulista e brasileira. A pujança canavieira paulista dava-se às custas da pobreza dos trabalhadores rurais, sejam eles migrantes ou “do lugar”.

O número de trabalhadores migrantes sazonais, principalmente cortadores de cana, oriundos da região do Vale do Jequitinhonha foi bastante numeroso em Santa Rosa de Viterbo, especialmente na década de 1990, associada também ao mito da “Califórnia Brasileira",. A fala de uma migrante estabelecida no bairro Nosso Teto, periferia de Santa Rosa de Viterbo, acerca dos itinerários e das expectativas da migração, foi registrada em matéria jornalística:

Foi o sonho de encontrar emprego, comprar uma terrinha, quem sabe deixar o Vale do Jequitinhonha que os trouxe para a região; diziam que " lá dá muito emprego, tem muito dinheiro". "Meu marido vinha todo ano fazer a safra, cortava cana, dormia no alojamento e levava as bóias frias para comer no serviço. Esquentava lata como a gente dizia. Depois, ele foi acostumando na cidade, arranjou casa no Nosso Teto (um conjunto de 1200 casas populares com população de mais de 8000 pessoas), a prestação era baixa e a gente resolveu vir morar todo mundo aqui, porque dizia que aqui ia melhorar cada dia mais (Caros Amigos Especial, $\mathrm{n}^{0}$. 61, p.24).

5 Expressão registrada na exibição de reportagem no Globo Repórter comparando a renda per capita da região de Ribeirão Preto à da Califórnia. A repercussão desta matéria foi tamanha, a ponto de exercer uma grande influência nos fluxos migratórios, sobretudo de trabalhadores sazonais para a região. Para uma outra leitura desse fato, sugerimos o vídeo "Califórnia à Brasileira” (1991, 24 min.), de José Roberto Novais. 
Esse grande fluxo de trabalhadores se dirigiu para boa parte da região canavieira de Ribeirão Preto, pois a colheita necessitava de mão de obra abundante e de baixa remuneração, sem exigência de maiores habilitações de trabalho.

A “chegada do estranho”, durante a safra, é vista com desconfiança e preconceito pelos “nativos”, com seus elementos culturais e seu modo de vida como registra o jornal O Santarrosense, em abril de 1987: "Nessa época a cidade recebe uma quantidade muito grande de pessoas do sexo masculino e o medo de estranhos no convívio social deixa algumas famílias apavoradas”. ( $O$ Santarrosense, Santa Rosa de Viterbo, ano 1, nº 6, p.3, abr. de 1987).

A presença de cortadores de cana, em sua maioria migrantes, entre os meses de maio a dezembro, assumia novas proporções, afetando as relações cotidianas até então estabelecidas no interior da cidade.

Essa foi uma das preocupações de Vettorassi (2006) ao constatar o descompasso entre a ideologia de cidade violenta atribuída a uma aglomeração urbana do interior paulista em razão da elevação dos índices de criminalidade atribuídos a trabalhadores migrantes durante o corte de cana. Idéia enganosa, conforme constata a autora, sustentada por meio de uma criminalização impingida sobre os volantes migrantes pelos “nativos", ou seja, pelos moradores mais antigos, de descendência européia e residentes nos bairros centrais da cidade.

Representação semelhante a da autora está na frase publicada num jornal de Santa Rosa de Viterbo supracitada, reveladora da segmentação e dos estigmas criados e reproduzidos por uma "ideologia nativa”. Subtrai-se, portanto, dos trabalhadores migrantes, a convivência cotidiana, ao delimitar seus espaços no interior do núcleo urbano, contribuindo assim para uma leitura reduzida destes sujeitos sociais pelos ditos moradores mais antigos da cidade, facilitando o controle da usina e dos "gatos". Trata-se, portanto da imposição de uma sociabilidade controlada, de uma cidadania negada e não reconhecida, de corpos voltados para o labor, de comportamentos vigiados. 
Recentemente, nas safras 2004/2005 e 2005/2006, foi feito, por um delegado policial, um cadastro de todos os trabalhadores migrantes que, a partir do mês de março, se dirigem para a cidade de Santa Rosa de Viterbo a fim de iniciar-se no labor da colheita da cana.

Esse tratamento dispensado pela autoridade policial aos trabalhadores migrantes reforça sobre eles a marca dos preconceitos, dos estigmas, de ampliação do controle social - já intenso por meio da vigilância da usina, mesmo no espaço reprodutivo desses trabalhadores - manifesto por meio de discriminações que se revelam no plano étnico-racial e que são comumente relatados pelos “nativos”, como já expresso anteriormente. Esse fato foi amplamente relatado pela imprensa regional:

O delegado de Santa Rosa de Viterbo, resolveu acionar os empreiteiros da cidade para que eles façam um cadastramento de todos os migrantes que forem contratados para a safra de cana-de-açúcar este ano. A decisão foi tomada depois que uma briga, domingo, em um bar entre trabalhadores rurais e um comerciante provocou a morte de duas pessoas e ferimentos em cinco.

No mesmo dia, uma criança de cinco anos foi estuprada por um rapaz de 22 anos. Os dois crimes ocorreram no bairro Nosso Teto, periferia da cidade.

"Eles vêm para a cidade na época de safra e isto faz aumentar a violência. Estes rapazes da briga do bar são todos mineiros. O do estupro também não é da cidade. Muita gente pode dizer que isto é discriminação, mas não é. Quando eles estão na cidade a criminalidade aumenta”, afirma o delegado. "Quero uma ficha com o nome, endereço, RG e até com foto. Este cadastro vai ter que ser enviado à delegacia”, completa. (Disponível em <www.jornalacidade.com.br>. Acesso em 25 abr. 2006)

Este tratamento, considerado “necessário” pela autoridade policial, fere o direito, assegurado pela Constituição, de ir e de vir destes sujeitos sociais. Longe de compreender a realidade desses trabalhadores que produzem a riqueza dessa região, o delegado de policia, assim como boa parte da população local, incute novas formas de controle social que se espraiam para o 
espaço reprodutivo desses trabalhadores, nas periferias e pensões durante seis a sete meses por ano. Trata-se de uma forma sutil de criminalização da pobreza, sustentada por formas de discriminação étnico/racial e regional atribuindo a eles a culpa por todos os problemas, incertezas e males que as autoridades, instituições e pessoas não querem assumir e com os quais não querem se comprometer. No tocante ao assunto, assim coloca Silva (2006, p. 12):

A ideologia discriminatória, que camufla o preconceito racial, dado que a maioria dos migrantes não é branca, se estende aos residentes, ex-migrantes nas cidades dormitórios da região, tornados verdadeiros "outsiders" (negros, mineiros, nordestinos) em contraposição aos “estabelecidos” (originários das cidades, brancos e descendentes de antigos colonos italianos).

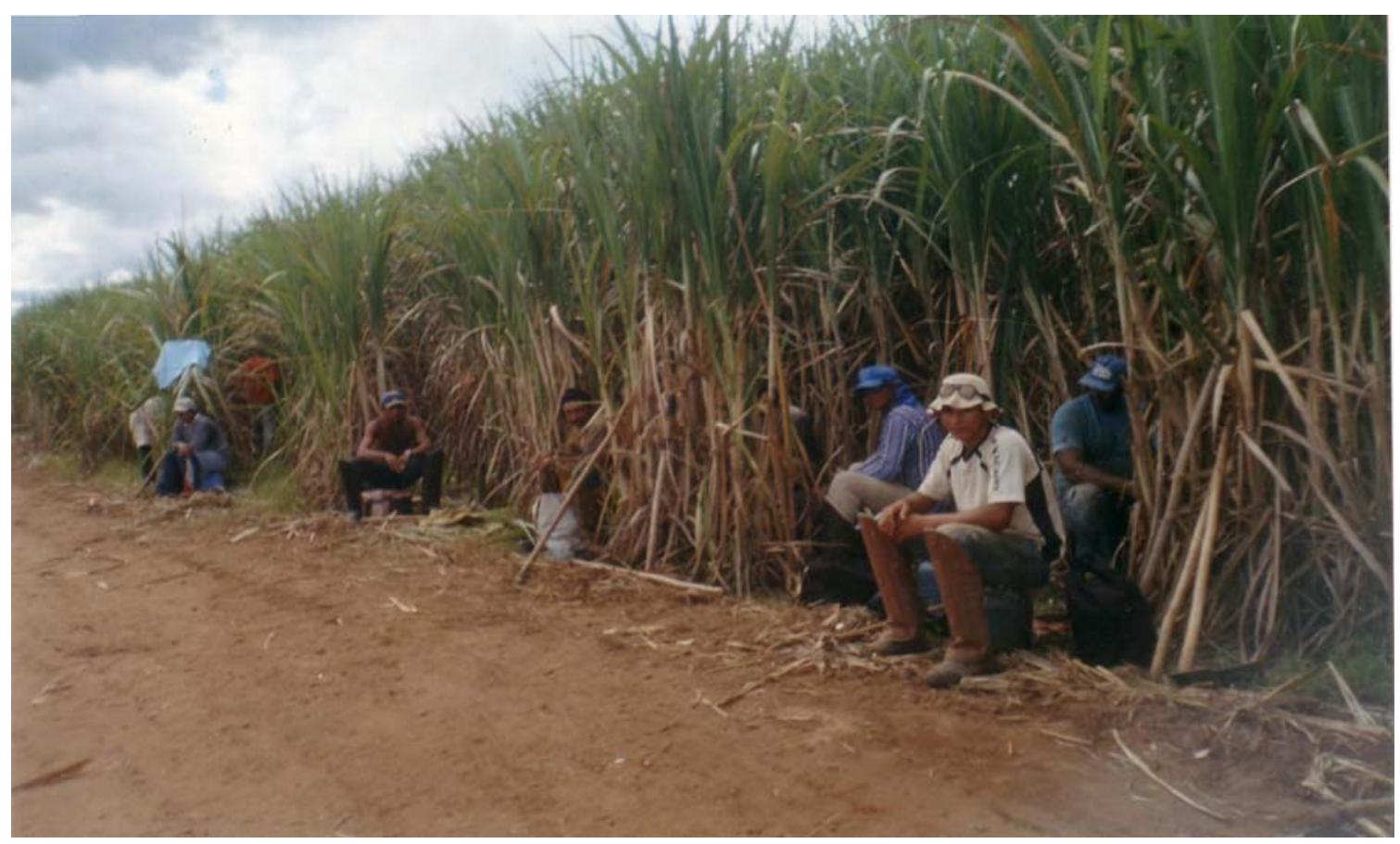

Figura 21 - Trabalhadores migrantes. Pausa para o almoço no plantio da cana. Fazenda Santa Sofia, Santa Rosa de Viterbo/SP.

(Autor: André Eduardo Ribeiro da Silva, 20 mar.2006). 
O conflito e a violência são marcas que acompanham o processo de territorialização da agroindústria canavieira na Fazenda Amália. Marcas que não se apagaram com o desenvolvimento do assalariamento e adoção do trabalho volante nos talhões de cana.

A década de 1980, em particular, foi sacudida por inúmeras manifestações grevistas, em parte geradas pelo contexto do movimento sindical brasileiro que vivenciava desde as greves dos metalúrgicos do $\mathrm{ABC}$, no final da década de 1970, à possibilidade de um “novo sindicalismo”, diferente do modelo proposto e controlado pelo Estado durante o golpe militar, bem como às lutas dos movimentos sociais pela redemocratização do país.

No movimento sindical dos trabalhadores rurais, dentre os quais figura o trabalhador canavieiro, significava romper com o modelo da Contag, ancorado num sindicalismo assistencial e em obediência à Lei de Greve imposta pelo golpe militar (THOMAZ JR., 2002, p.298), arrefecendo as agitações políticas levadas a cabo pelos trabalhadores rurais em meados das décadas de 1950 e 1960.

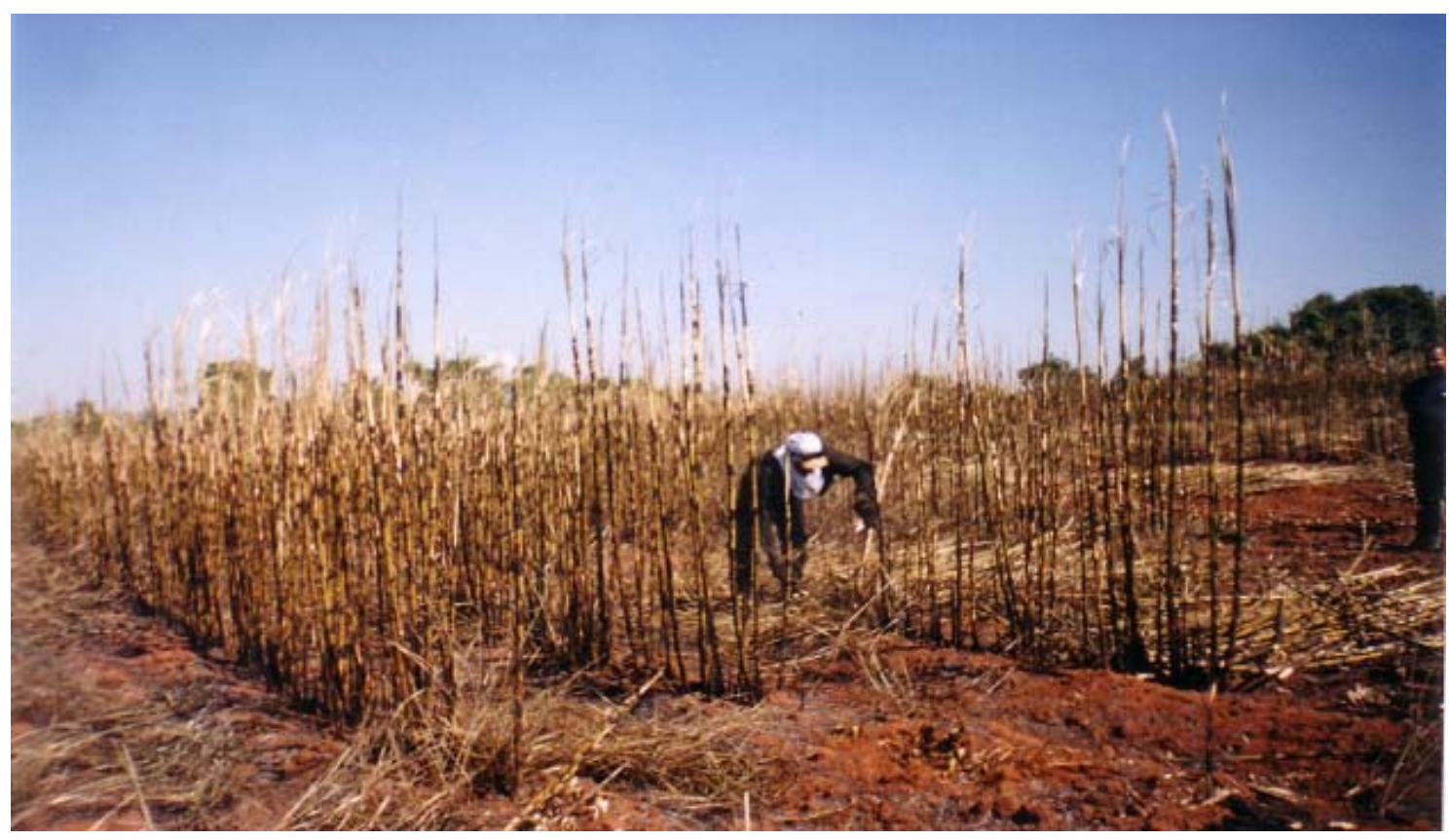

Figura 22 - A face oculta do trabalho nos canaviais paulistas. Cortador de cana em terra arrendada da Usina Santa Rita.

(Autor: André Eduardo Ribeiro da Silva, setembro de 2006). 
Esses acontecimentos não passaram de forma despercebida entre os trabalhadores da lavoura canavieira da Usina Amália, como pode ser percebido por meio de sua adesão aos movimentos grevistas de trabalhadores rurais que varriam as principais áreas canavieiras do estado de São Paulo, sobretudo na segunda metade da década de 1980.

Em julho de 1986, acompanhando a greve dos cortadores de cana, deflagrada em 16 de junho pelos trabalhadores da usina Diamante, radicados em Jaú e Itapuí - que resultou na morte de dois trabalhadores que participavam do movimento pela polícia militar em Leme -, o movimento grevista dos trabalhadores rurais contaram também com a adesão de vários municípios da região de Ribeirão Preto, incluindo em sua fase final os trabalhadores da lavoura canavieira da usina, que em sua maior parte eram oriundos dos municípios de Santa Rosa de Viterbo e Cajuru. Os trabalhadores canavieiros paralisaram suas atividades entre os dias 19 e 22 de julho, depois de decorrido mais de um mês do início do movimento (ALVES,1991, p. 225), como pode ser visto por meio da figura abaixo:

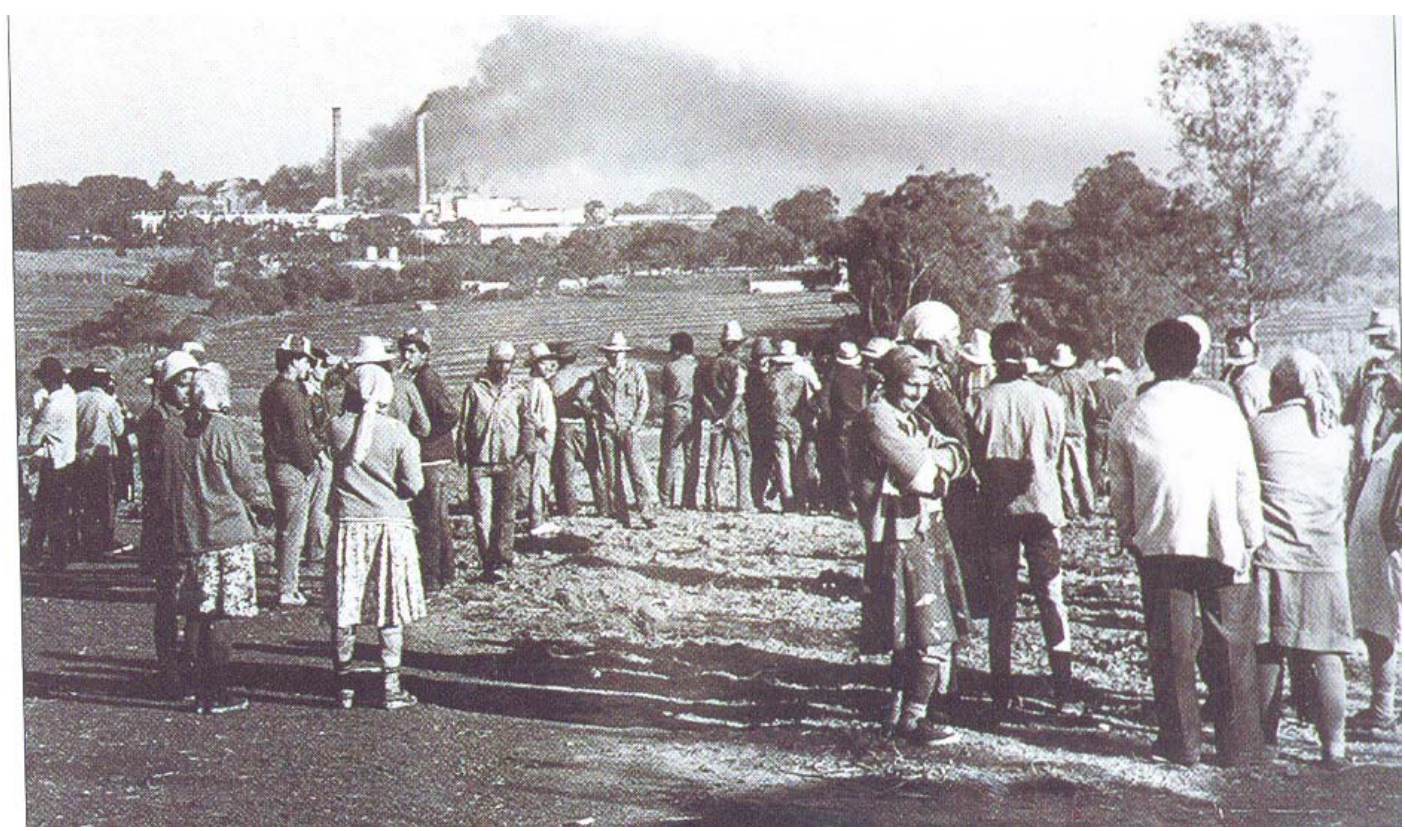

Figura 23 - Greve vitoriosa. Na manhã do dia 19 de agosto de 1986, os trabalhadores rurais de Amália aderiram à greve e pararam a usina, contra a exploração patronal. Fonte: Silva (2001, p. 64) 
A greve foi encerrada em 22 de julho, a partir de um acordo firmado entre a FAESP (Federação da Agricultura do Estado de São Paulo) e a FETAESP (Federação dos Trabalhadores na Agricultura do Estado de São Paulo), sob a mediação do Ministério do Trabalho, na cidade de São Paulo (Cf FIM da greve no campo: Trabalhadores rurais vencem outra batalha. Santa Rosa Notícias, Santa Rosa de Viterbo, ano 7, n 132, p. 6, 7 ago. 1986). O acordo resultou num aumento do pagamento da diária de CZ\$ 43 para CZ\$ 50, tendo também recebido um acréscimo de CZ\$ 7,50 decorrente da hora/trabalho. Na entressafra do ano seguinte, participam de um outro movimento grevista, de alcance regional, segundo Alves (1991, p. 234).

Em 1990, um outro contencioso marca as relações entre capital e trabalho na Agro Industrial Amália S.A. Tratava-se de uma ação em cumprimento das "180 horas", levada adiante pelo Sindicato dos Trabalhadores da Alimentação de Santa Rosa de Viterbo. "Um acordo firmado entre as usinas e os sindicatos, em novembro de 1989, dizia que elas deveriam pagar um abono de 240 horas aos operários em janeiro de 1990, resolvendo uma diferença de IPC e INPC de janeiro de 89 , mais 25,68\% de reajuste salarial a partir de dezembro de 89. A Amália pagou 60 horas mais 6,56\% de reajuste, alegando já haver pago 17,64\% a partir de junho daquele ano. O Sindicato de Santa Rosa entrou na justiça para receber a diferença, ou seja, as 180 horas e os $17,94 \%$, uma vez que todas as outras usinas cumpriram o acordo sem ressalvas (O Santa Rosa, Santa Rosa de Viterbo, ano 1, n ${ }^{\circ} 19$, p.3, 29 set.1990.). O acordo também beneficia os trabalhadores rurais, porém o Sindicato dos Trabalhadores Rurais não entrou na justiça contra a usina (Santa Rosa Notícias, Santa Rosa de Viterbo, ano 1, nº 173, p. 1,4 abr. 1990.). A sentença definitiva das "180 horas" foi proferida pela Junta do Trabalho de Porto Ferreira somente em 9 de fevereiro de 1994 (NÃO existem recursos para as 180 horas: sindicato tem que executar Matarazzo. Santa Rosa Notícias, Santa Rosa de Viterbo, ano 11, nº 193, p.7, 7 mai.1994). 
Os movimentos grevistas dos trabalhadores da parte industrial e da lavoura da Agro Industrial Amália S.A., assim como das demais empresas do grupo Matarazzo, sediadas em Santa Rosa de Viterbo, foram motivados por questões relativas ao conjunto dos trabalhadores da agroindústria canavieira, em particular dos trabalhadores rurais, como o transporte precário de trabalhadores da cidade até a sede da Fazenda Amália, tendo sido acompanhados, e mesmo defendidos pelo jornal local Santa Rosa Notícias ${ }^{6}$.

Por meio de várias edições do jornal local Santa Rosa Notícias, pudemos acompanhar a luta dos trabalhadores da lavoura canavieira da Fazenda Amália, assim como as condições de vida e trabalho desses sujeitos sociais que, no início da década de 1980, passavam a ter contornos espaciais bem nítidos no núcleo urbano santa-rosense, com a construção de um grande conjunto habitacional numa área afastada três quilômetros do centro da cidade, carente de infra-estrutura e atendimento social. Tratava-se do conjunto habitacional Liliana Urtiaga Andreazza, produto do Projeto Nosso Teto ${ }^{7}$. A cidade servia a usina, fornecendo as condições materiais para a reprodução da força de trabalho dos canaviais de Amália, em sua periferia urbana.

Tal iniciativa aguçou ainda mais as contradições sociais, econômicas, políticas e culturais, no interior do núcleo urbano santa-rosense, com atitudes preconceituosas associadas à marginalidade deste bairro e de sua gente em relação ao restante da cidade. Em grande parte, produto da segregação sócio espacial do modo de produção capitalista, ambas as partes se complementam e se contradizem. A questão da segmentação espacial na cidade e no interior do espaço produtivo entre trabalhadores canavieiros e os moradores do centro da

\footnotetext{
${ }^{6}$ Produto do momento que permeava a restauração democrática do Estado brasileiro, esse jornal publicava e discutia politicamente temas pertinentes que atingiam o cerne das conflituosas e históricas relações usina-cidade. Foi nele que encontramos a maior divulgação e crítica desses fatos.
}

${ }^{7}$ NOSSO Teto: O Isolamento do Povo - A Triste Herança do Prefeito. Santa Rosa Notícias, Santa Rosa de Viterbo, ano 3, nº 57, p.4, 7 mai.1982,. 
cidade, em sua maioria de descendência européia fomentadora de estigmas e de imagens dissimuladas do trabalhador e do trabalho nos canaviais, foi estudada por Silva (1999) e Vettorassi (2006), pesquisas já referidas neste trabalho.

Conforme expressão apropriada por um depoente em Vetorassi (2006, p.20) a "entrada feia", referindo-se à cidade de Guariba, em Santa Rosa de Viterbo, envolve o seu bairro mais populoso, também o mais carente, habitado em sua maioria por trabalhadores rurais, "locais", migrantes estabelecidos e volantes sazonais nas pensões dispersas pelo bairro. Era a cidade se expandindo para abrigar a força de trabalho para os canaviais, na qual o poder local se rendia mais uma vez aos apelos da usina, que também se faz latifundiária ${ }^{8}$.

Outrossim, segundo Lencioni (1985, p.145), o processo de capitalização no campo está relacionado à conformação da periferia urbana nas pequenas cidades com o desenvolvimento da agricultura capitalista:

Neste sentido é que dizemos que foi o processo de intensificação do capital na agricultura que determinou a nova fisionomia da cidade. Esta se redefiniu como um espaço de reprodução da força de trabalho do campo. O processo de proletarização do trabalhador rural produziu um novo espaço na cidade expresso na formação de uma periferia urbana, como manifestação espacial particular do processo de reprodução dessa força de trabalho. Desta forma a cidade

\footnotetext{
${ }^{8}$ Ainda no que tange à utilização das terras no município de Santa Rosa de Viterbo é importante destacar o monopólio da utilização dos solos de maior fertilidade natural em poder da usina (latossolos vermelhos, que correspondem a uma área aproximada de 14.000 hectares, segundo conversa com técnico responsável na Casa da Lavoura local). As demais classes de solos - regossolos, hidromóricos e latossolos vermelhoamarelo - ocupam uma extensão respectivamente de 13.000, 400 e 900 hectares. Os cultivos de cana se dão prioritariamente nas áreas de latossolo vermelho, localizadas no norte do município, na faixa limítrofe com os municípios de Cajuru, São Simão e Tambau, onde se encontra a maior parte das terras próprias da usina no município (Cf. EMBRAPA / IAC. Mapa Pedológico do Estado de São Paulo. Escala 1:500. 000. 1999). Os demais solos são dedicados à pastagem ou à atividade de reflorestamento, mais no centro-sul de Santa Rosa de Viterbo (SILVA, 2004, p. 68).
} 
compreendida como materialização de determinadas condições gerais de produção manifesta-se, a cada momento, como resultado histórico determinado.

Mas também há outra possibilidade de interpretação do espaço urbano, em particular das periferias habitadas pelos trabalhadores rurais. $\mathrm{O}$ espaço das cidades é também o espaço do contra-poder. De acordo com Silva (1999, p. 241), a concentração espacial nas cidades também leva à gestação e o desenvolvimento das recusas coletivas. Assim, foi nos movimentos grevistas de trabalhadores rurais ao longo da década de 1980, em particular no de Guariba, em maio de 1984, que as manifestações e a organização dos trabalhadores ocorreram em bairros onde concentravam esses moradores.

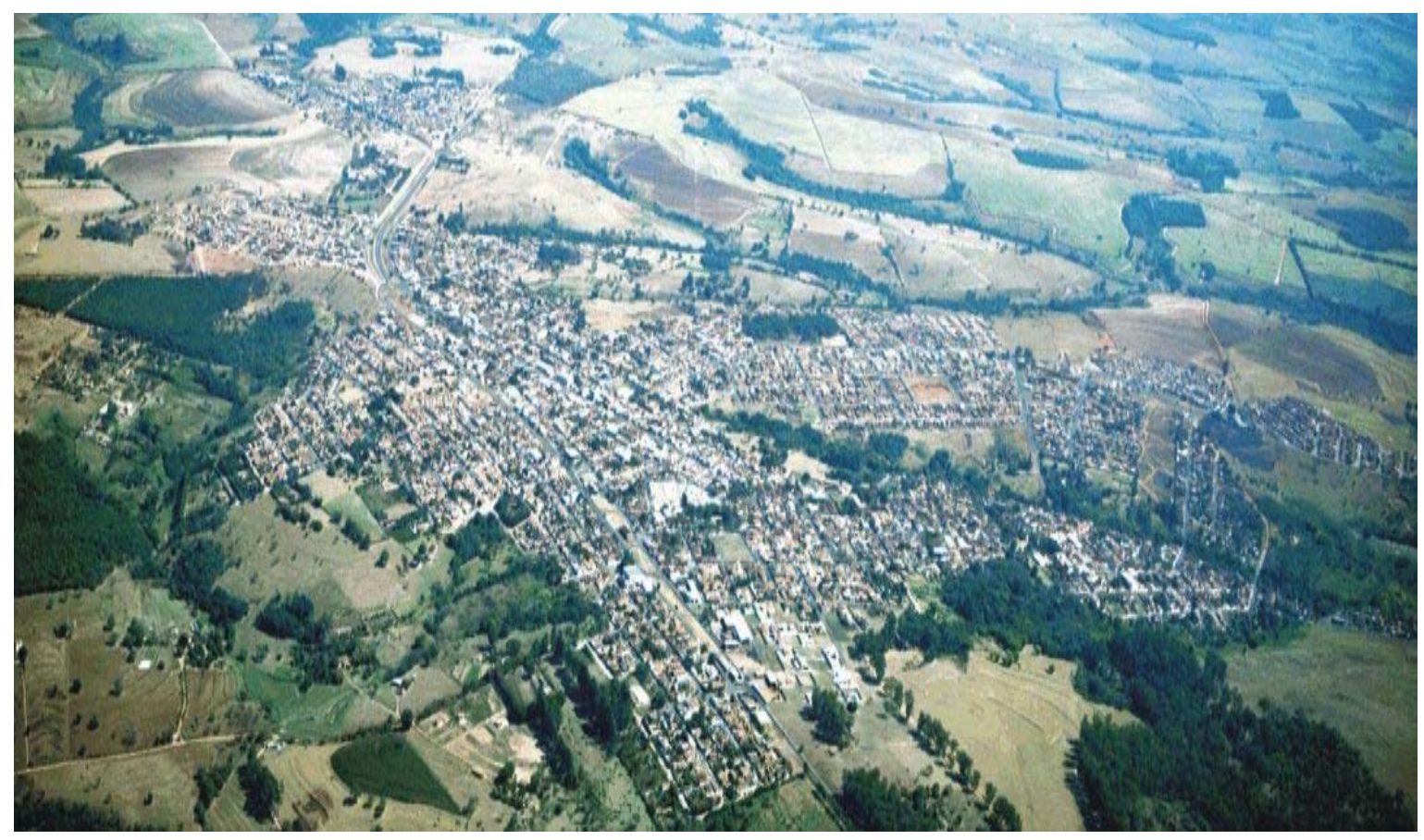

Figura 24 - Fotografia aérea da cidade de Santa Rosa de Viterbo.

Disponível em <www.santarosa.sp.gov.br> Acesso em 21 abr. 2007

Nesse sentido, consideramos fundamental a contribuição de Silva para nosso trabalho, ao adensar a leitura desses sujeitos sociais em suas múltiplas dimensões, que extrapolam o seu mundo do trabalho, de seu espaço produtivo 
nas periferias urbanas e de sua submissão ao capital, isto é, de sua redução à força de trabalho, de sua condição de "bóias-frias".

As investigações de Silva nos permitem lançar um novo olhar sobre o urbano e sobre a relação cidade-campo, num contexto do desenvolvimento das relações capitalistas de produção no meio agrário brasileiro. A cidade, que não se restringe unicamente a locus de reprodução da força de trabalho do campo, ou de espaço do controle do capital, mas também em espaço do contra-poder, da busca de elementos para revificar o tempo passado, materializando práticas, concepções e um modo de vida, que mesmo deslocados do espaço de materialização original, e em constante conflito com o presente, nutre as múltiplas possibilidades de reproduzir a vida, mesmo de uma forma precária, transitória, muitas vezes em condições miseráveis.

A cidade lida como materialização das condições gerais de produção e consumo no campo, conduzindo também ao processo de capitalização das atividades agrárias é também o espaço de luta dos trabalhadores rurais da lavoura canavieira.

Do ponto de vista demográfico, a população residente na cidade de Santa Rosa de Viterbo aumentou de pouco mais de 4.000 habitantes, em 1960, para mais de 20.000 habitantes quatro décadas depois. Contudo, foi na década de 1980 que este processo se consolidou de forma definitiva, em grande parte decorrente do ritmo de crescimento da agroindústria canavieira e da construção do bairro "Nosso Teto", na periferia urbana para abrigar os trabalhadores rurais, muitos deles ex-colonos da cana, mas hoje também muitos migrantes estabelecidos há alguns anos na cidade. Como já foi dito, a cidade expandia, oferecendo aos trabalhadores canavieiros a sua periferia urbana.

Entretanto, de acordo com o último censo agropecuário (1995-1996), a terra continuava concentrada no município de Santa Rosa de Viterbo, pois dos 118 estabelecimentos rurais, 86, ou seja, 72,9\% deles possuíam até 100 
hectares, enquanto apenas um estabelecimento detinha uma área superior a 2.000 hectares.

Tabela 8

Santa Rosa de Viterbo -SP

Estabelecimentos por grupo de área total (ha)

1996

\begin{tabular}{|l|c|}
\hline Classes de área (em hectares) & N $^{\text {o de estabelecimentos rurais }}$ \\
\hline Menos de 10 & 11 \\
\hline 10 a menos de 100 & 75 \\
\hline 100 a menos de 200 & 21 \\
\hline 200 a menos de 500 & 8 \\
\hline 500 a menos de 2000 & 2 \\
\hline 2000 e mais & 1 \\
\hline
\end{tabular}

Fonte: Censo Agropecuário de 1995-1996.

Nas ultimas décadas constatamos uma intensificação das relações entre a agricultura capitalista canavieira e a urbanização no município de Santa Rosa de Viterbo. Não envolvem unicamente a esfera produtiva já que impõe relações desiguais e a criação/recriação de territórios marcados por lutas e contradições que se processam no interior da sociedade, da ordem e do contrapoder, da submissão e da recusa. Portanto, o território é dinâmico, flexível, aberto, em permanente construção/reconstrução pelos sujeitos sociais.

Contudo, as múltiplas dimensões do processo de territorialização da agroindústria canavieira na Fazenda Amália recriaram a cidade, segundo a lógica de desenvolvimento capitalista no campo, mas também criou na cidade o espaço do contra-poder, das práticas cotidianas de resistência, mesmo mantendo intocada a apropriação privada da terra e a "modernização conservadora” perpetuada de forma avassaladora, vestindo antigas roupagens 
e legitimando a desigualdade social e a violência, marca histórica deste processo no Brasil.

\subsection{O declínio das Indústrias Matarazzo e a concordata de Amália}

Um fato importante marca o meio empresarial brasileiro e a Fazenda Amália, em particular, em fevereiro de 1977, a morte do Conde Francisco Matarazzo Júnior.

O falecimento de Matarazzo Júnior prenunciou a bancarrota do grupo familiar, envolto por dívidas e cercado pela concorrência de poderosas empresas internacionais, distantes do modelo centralizador e hierárquico de gestão de suas empresas. Com a sua morte, a administração do grupo familiar é passada a sua filha caçula, Maria Pia Esmeralda Matarazzo, seguindo o habitual modelo patriarcal de sucessão do conglomerado industrial, assim colocado em matéria jornalística:

A empresária Maria Pia Esmeralda Matarazzo, assume o comando do grupo, com a morte do pai, Conde Francisco Matarazzo Jr, em 1977. No comando ela teve de administrar uma dívida de quatrocentos milhões de dólares. Cerca de 180 milhões de dólares foram pagos com a venda de propriedades e obras de arte pertencentes à família ( $O$ Jornalzão, Santa Rosa de Viterbo, ano 5, $\mathrm{n}^{0}$ 200, p. 5, 16 out. 1999).

A morte de Matarazzo Júnior também representa, segundo Martins (1981, p. 150), o fim da personificação da ideologia do sucesso pelo trabalho, criado e reproduzido pelo Conde Matarazzo e, depois, extensiva ao Conde Matarazzo Júnior, bem como às suas empresas na forma de mitos e representações que se confundem com a própria ideologia da industrialização brasileira, nas primeira metade do século passado. De acordo com Martins (1981, p. 150): 
Os últimos quarenta anos de vida do Conde Chiquinho foram os quarenta anos de morte do mito Matarazzo [...]. A deterioração do mito burguês foi facilitada pela constatação de que o conde rico não era a conseqüência do seu próprio trabalho [...].A morte do burguês mítico ocorre com a emergência ampla do processo de concentração do capital. Foi uma longa agonia, marcada pelas vacilações da classe operária que se exprimiram numa consciência ambígua - a consciência que procurou revestir de coerência o antagonismo entre o trabalho proletário criador e a concepção burguesa do trabalho.

Muitas dessas representações a respeito do empresário e das empresas Matarazzo são encontradas entre os ex-colonos da Fazenda Amália, sendo manifestos em alguns de nossos depoimentos colhidos. Imagens e representações do empregador como sendo o "pai da pobreza”, o "bom patrão”, de uma certa proximidade no relacionamento com os trabalhadores, ponto de vista, portanto, distinto da visão violenta em que se deu a expulsão de milhares de famílias de colonos, versão negligenciada pela historiografia oficial.

A abordagem de Silva (2006) revela, portanto, um mundo subterrâneo, invisível, em permanente conflito nos canaviais da Fazenda Amália, distante das imagens criadas, muitas delas míticas sobre a família Matarazzo.

Já Vichnewski (2004, p.108), em sua análise sobre as indústrias de beneficiamento de algodão do grupo familiar entre as décadas de 1930 e 1960 pelo interior paulista, caracteriza as “cidades dos Matarazzo”. Assim coloca o autor:

Outro fato que se repete, na maioria das cidades onde foram instaladas as indústrias Matarazzo; é a representatividade que a IRFM trouxe para a comunidade local, e era traduzida em progresso, poderio econômico e até em status de riqueza para a população e para a cidade. Isso despertava nas autoridades locais, ações como nomear ruas e praças com o nome Conde Francisco Matarazzo ou do seu filho Conde Francisco Matarazzo Jr, e até em sua intitulação como cidadão da 
cidade. A presença das indústrias Matarazzo ultrapassou os muros da fábrica, para se inscrever na trama urbana da cidade.

Podemos apontar também a importância das chaminés do grupo familiar para a economia e os empregos do município santa-rosense. Em meados da década de 1950:

destaca-se como indústria principal e quase soberana a produção de açúcar, seguida de perto pelo ácido cítrico, éter sulfúrico, papel, amido e conservas, todas de propriedade das Indústrias Reunidas F. Matarazzo, onde labutam 1.267 operários dos 1.280 existentes”. (Enciclopédia dos Municípios Brasileiros, Estado de São Paulo, p. 112).

Podemos constatar então que o maior empregador do município de Santa Rosa de Viterbo, tanto das ocupações agrícolas como industriais era representado pelas empresas do Conde Matarazzo, em particular, a maior delas, a Usina Amália. A riqueza econômica do município, em suma, representava a riqueza produzida e apropriada pelo grupo familiar.

Contudo, passado o falecimento de Matarazzo Júnior e a sucessão nos negócios de suas empresas, as Indústrias Reunidas F. Matarazzo inauguram, na década de 1980 um processo de reestruturação, no qual várias de suas unidades industriais foram fechadas, vendidas ou mesmo tiveram o seu pedido de concordata, iniciado com o fito de especializar-se em alguns setores produtivos. As Indústrias Matarazzo constituíam então, no início dos anos 1980, 48 empresas com 19.892 funcionários $^{9}$ e uma volumosa dívida, não poupando nem mesmo as instalações industriais, plantações e terras na Fazenda Amália.

9 “Com o programa de reestruturação das empresas, aprovado em dezembro, o conglomerado deverá ficar restrito a 7 empresas”( Santa Rosa Notícias; Santa Rosa de Viterbo, ano 1, nº 6, p.1, 19 jan. 1980). 
Pudemos verificar o fato, a partir da análise de quase todas as certidões de matrículas fornecidas pelos Cartórios de Registros de Imóveis dos municípios que possuem terras da Fazenda Amália, no qual parte significativa da propriedade foi dada como garantia de empréstimos e financiamentos das Indústrias Matarazzo junto a instituições financeiras e, principalmente, à COPERSUCAR (Cooperativa dos Produtores de Cana, Açúcar e Álcool do Estado de São Paulo), como veremos mais à frente.

Trata-se de um elemento fundamental para entendermos o processo de fragmentação da Fazenda Amália, na primeira metade dos anos 1990, e da aquisição de parcelas importantes da mesma por parte de vários proprietários, situação que se diferencia do controle da grande propriedade desde o início de sua constituição, na última década do século XIX.

Temos, portanto, manifestações importantes de que a história da fazenda Amália, administrada pelo grupo Matarazzo, não pode ser segmentada da história de seu empresário e das Indústrias Reunidas F. Matarazzo. É por isso que buscamos em nossas reflexões relacionar o processo de territorialização da agroindústria canavieira, tendo como base a Usina Amália e as relações de produção na Fazenda Amália, não somente com o contexto do setor sucroalcooleiro paulista e nacional, mas com o grupo econômico mais rico da América Latina até a década de 1960.

Por meio de uma medida provisória baixada pelo governo federal em dezembro de 1990, o grupo econômico proprietário da usina e da Fazenda evitaram a falência de várias de suas empresas.

Como mencionado anteriormente, parte importante das terras da Fazenda Amália foram dadas em garantia a financiamentos feitos pelo grupo Matarazzo e muitos não cumpridos, situação que provocou uma alteração na conformação fundiária da então Fazenda Amália - controlada pela família Matarazzo e ocupada produtivamente com plantações de cana-de-açúcar por meio da venda e dação das terras em pagamento de parte destas terras para 
pagamento de dívidas, alterando significativamente a configuração fundiária da grande propriedade

A tabela abaixo revela a configuração fundiária da Fazenda Amália até o início de agosto de 1990:

Tabela 9

Fazenda Amália

Configuração fundiária em agosto de 1990 (em hectares)

\begin{tabular}{|l|c|}
\hline \multicolumn{1}{|c|}{ Município } & Área \\
\hline Cajuru & $5.049,1$ \\
\hline Santa Cruz da Esperança & $2.955,6$ \\
\hline Santa Rosa de Viterbo & $6.245,6$ \\
\hline São Simão & $4.442,6$ \\
\hline Serra Azul & 542,1 \\
\hline Tambaú & $2.875,4$ \\
\hline Área Total & $22.110,4$ \\
\hline
\end{tabular}

Fonte: Certidões de matrículas fornecidas pelos Cartórios de Registro de Imóveis de Cajuru.(7 ago.2006, 17 nov.2006 e 3 jan. 2007), Cravinhos (16 nov. 2006), Santa Rosa de Viterbo (26 jul. 2006 e 5 jan. 2007), São Simão (21 nov. 2006 e 4 jan.2007 ) e Tambaú (28 jul.2006).

Parte dessas terras, pertencentes à Fazenda Amália, foi dada em pagamento à Copersucar (Cooperativa dos Produtores de Cana, Açúcar e Álcool do Estado de São Paulo), no início da década de 1990, como garantia hipotecária a diversas dívidas contraídas pela Agro Industrial Amália S.A. junto à cooperativa, sobretudo a partir da segunda metade dos anos 1980. Várias certidões de imóveis ${ }^{10}$ revelam que a dívida da empresa perante à Copersucar se deve a "avais e fianças em operações de crédito realizadas pela financiada [Agro Industrial Amália S.A.], como forma de obtenção de numerário destinado ao custeio de sua produção de açúcar e de álcool, obrigações essa vencidas e repactuadas no decorrer das safras de 87/88, 88/89, 89/90 e 90/91 e subseqüentes"

${ }^{10}$ Certidões de matrículas de imóveis obtidas nos Cartórios de Registro de Imóveis de Cajuru e São Simão entre agosto de 2006 e janeiro de 2007. 
Outra parte das terras foi vendida a várias empresas, dentre elas destacam-se duas: a CEIET Agro Mercantil Ltda (cuja denominação social foi alterada para Canamor Agro Industrial e Mercantil S.A., em julho de 1999) e Irmãos Cury S.A.

A primeira adquirente, não atua diretamente na atividade produtiva canavieira, tanto na parte agrícola como na industrial, tem sede na capital paulista e também se tornou proprietária das instalações industriais da antiga usina $^{11}$. Já a segunda empresa é comandada por Nelson Afif Cury, fazendeiro e dono de duas usinas na região de Ribeirão Preto, a Usina Maringá, localizada no município de Araraquara, e a Usina Santa Rita, sediada em Santa Rita do Passa Quatro ${ }^{12}$.

A fragmentação fundiária da Fazenda Amália foi acompanhada por uma conjuntura do setor sucroalcooleiro, assinalada por muitos autores como sendo um processo de desregulamentação do setor econômico, particularmente após a extinção do IAA e do Proálcool, no início da década de 1990.

A adoção de formas de gestão do capital; a expansão da mecanização no campo; as inovações na automação, na parte industrial; a diversificação produtiva; os arranjos nas relações de trabalho etc, ou seja, os elementos que

${ }^{11}$ Parte das terras adquiridas pela CEIET Agro Mercantil Ltda foram acordadas por meio de compromissos de compra e venda de terras firmadas com o grupo Matarazzo em 6 de agosto de1990, alguns deles aditados em cartório muito antes do anúncio da concordata do grupo familiar no final de 1990. Nota-se também que, conforme esses registros, as escrituras públicas de compra e venda dessas terras é de 22 de novembro de 1990, um mês antes da já mencionada concordata. (Fonte: Certidões de matrículas de imóveis obtidas junto aos Cartórios de Registro de Imóveis de Cravinhos( município de Serra Azul, com três matrículas), de Cajuru (cinco matrículas, sendo 4 referentes ao município de Cajuru e uma ao município de Santa Cruz da Esperança), São Simão (4 matrículas) e Santa Rosa de Viterbo (3 matrículas).

12 A Usina Santa Rita - Açúcar e Álcool S.A., é atualmente propriedade do grupo Cury. Ela foi fundada em 1925, com a denominação de Usina Vassununga, no município de Santa Rita do Passa Quatro, às margens do rio Mogi-Guaçu, próximo ao limite com o município de Descalvado (BRAY,1989, p. 117). A Usina Vassununga, logo, se tornou uma das maiores usinas paulistas, contando no início da década de 1940 com 12.100 hectares de terras próprias de cana-de-açúcar, segundo Carli (1943, p. 137). 
revelam o processo de reestruturação das relações de produção e trabalho, no interior da agroindústria canavieira, não estão separados do conceito de territorialização do monopólio refletida por Thomas Jr. (1988) em suas pesquisas no final da década de 1980.

Pensamos que o emprego desse conceito ainda é valido, visto que a "construção do monopólio agroindustrial assegura ao capital um extraordinário poder político e econômico” (THOMAZ JR., 1988)

Para corroborar a idéia, assim nos diz Thomaz Jr (2002, p. 200):

Com a materialização do processo específico de internalização do "progresso técnico", processa-se outro salto qualitativo em direção ao (novo) eixo da acumulação do capital. Apesar de não inviabilizar o anterior, ao contrário, o redimensiona, com o propósito de superar a relação centrada na transferência da mais-valia, na forma de renda da terra (com a territorialização do monopólio), sinalizando, agora, para a hegemonia na apropriação da mais valia relativa e para a subsunção real do trabalho no capital.

Trata-se, na análise que Antunes (1999, p.31) faz do processo de reestruturação produtiva, do processo de reorganização do capital e de seu sistema ideológico e político de dominação.

Essas novas relações na produção canavieira também propiciaram grandes pesquisas no campo da Genômica, em busca de variedades mais produtivas e com maior poder de resistência a doenças e pragas além de maior conhecimento dos mecanismos biológicos da cana.

O sequenciamento genético da cana, anunciado em novembro de 2000, foi o primeiro feito de um vegetal no país e contou com amplos recursos oriundos tanto do Estado, principalmente por meio da FAPESP (Fundação de Amparo à Pesquisa no Estado de São Paulo), assim como do auxílio técnicocientífico de universidades (a maioria, públicas) e organizações de produtores, como a COPERSUCAR (Cooperativa dos Produtores de Açúcar e Álcool do Estado de São Paulo). 
A conclusão do Genoma da Cana, um ano e meio após ser anunciado publicamente a sua elaboração, vai ao encontro dos “sonhos" dos fazendeiros e fabricantes de açúcar e álcool do país. Vai se confirmando a aliança técnicocientífica com o desenvolvimento do grande capital agroindustrial no Brasil, prevendo-se, em breve, o lançamento de duas variedades de cana resistentes a duas pragas (a bactéria Leifsonia xyli e o fungo do carvão). As novas pesquisas, associadas a outros investimentos, elevam ainda mais a produtividade e a lucratividade do setor sucroalcooleiro, contribuindo indiretamente para a expansão dos canaviais, portanto, acirrando a concentração fundiária e de renda por parte do empreendimento agroindustrial canavieiro (FIORAVANTE, 2000).

Durante este mesmo período, a lavoura canavieira também passou por um pronunciado processo de diferenciação no campo produtivo, marcado pelas empresas com elevada rentabilidade agroindustrial e massivos investimentos de capital na área técnico-científica, como a contratação de mão-de-obra qualificada, crescimento da mecanização, informatização do setor reduzindo os custos de produção.

O acirramento da diferenciação, entre as unidades processadoras de açúcar e álcool, foi seguido por uma seqüência de falências e vendas de pequenas usinas, principalmente na área canavieira nordestina, mas também no estado de São Paulo, favorecendo a aquisição e a fusão de usinas, constituindo grandes grupos usineiros, seja em escala regional e mesmo nacional, fortalecendo empresas e grupos nesta disputa por redução nos custos de produção e de novas terras para expansão canavieira.

No final dos anos 1990, particularmente a partir de 1998, intensificaram-se as fusões e incorporações de grandes e médias usinas pelo Brasil, inclusive contando com um novo elemento, a participação crescente de grupos estrangeiros em associação com grandes empresas nacionais na aquisição de parte destes estabelecimentos; e grupos nordestinos, 
principalmente de Alagoas e Pernambuco, que se tornaram donos de várias usinas no Centro-Sul, especialmente em São Paulo.

A antiga Usina Amália foi arrendada por duas grandes usinas da região de Ribeirão Preto, especificamente a Usina da Pedra, a partir de 1998. Tratava-se de uma nova roupagem para a continuidade do processo de reprodução do capital e territorialização do poder econômico, político e social das agroindústrias canavieiras. É o que apresentaremos no capítulo a seguir. 
A Territorialização da Agroindústria Canavieira na antiga Fazenda Amália na década de 1990 e início dos anos 2000 


\subsection{A Reestruturação Produtiva do Capital Sucroalcooleiro na antiga}

\section{Fazenda Amália}

O que chamamos de reestruturação produtiva do capital sucroalcooleiro, é parte de um processo mais amplo, abrangendo vários setores econômicos, produtivos ou não. Corresponde ao que Alves (2000, p.13) denomina como sendo o novo "complexo de reestruturação produtiva" do capital, ou seja, "a procura de uma nova hegemonia do capital na produção, adequada à nova etapa do capitalismo mundial”.

Nos dias de hoje, o novo complexo de reestruturação produtiva se traduz por meio da incorporação de elementos do modelo toyotista, ou da "produção enxuta", com o fito de maximizar a produtividade do trabalho, objetivo histórico perseguido pelo capital, em razão das necessidades renovadas da acumulação capitalista. Trata-se, conforme Alves (2000, p.33), de apenas uma ruptura "no interior de uma continuidade plena", uma resposta do capital às suas necessidades estruturais.

Do ponto de vista econômico, social e político, o novo complexo de reestruturação produtiva é alicerçado por um conjunto de práticas derivadas da concepção neoliberal que dissemina, na sociedade os elementos necessários e favoráveis ao pleno desenvolvimento dos novos padrões de acumulação do capital. Nas palavras de Antunes (1999, p. 30):

Como resposta à sua própria crise, iniciou-se um processo de reorganização do capital e de seu sistema ideológico e político de dominação, cujos contornos mais evidentes foram o advento do neoliberalismo, com a privatização do Estado, a desregulamentação dos direitos do trabalho e a desmontagem do setor produtivo estatal, da qual a era Thatcher-Reagan foi expressão mais forte; a isso se seguiu também um intenso processo de reestruturação da produção e do trabalho, com vistas a dotar o capital do instrumental necessário para tentar repor os patamares de expansão anteriores (ANTUNES, 1999, p.30). 
Portanto, não se trata de algo novo, distinto do processo geral de reprodução capitalista que se sustenta a partir de um arcabouço ideológico e político de dominação, adequado a momentos determinados, como nos apresenta Antunes (1999), supracitado.

A posição é apoiada por Harvey (2004, p. 80-1), ao afirmar que

O capitalismo não pode sobreviver sem seus ajustes espaciais[...] O capitalismo tem recorrido repetidas vezes à reorganização geográfica (tanto em termos de expansão como de intensificação) como solução parcial para suas crises e seus impasses. Assim, ele constrói e reconstrói uma geografia à sua própria imagem e semelhança. Constrói uma paisagem geográfica distintiva, um espaço produzido de transportes e de comunicações, de infra-estruturas e de organizações territoriais que facilita a acumulação do capital numa dada fase de sua história, apenas para ter de ser desconstruído e reconfigurado a fim de abrir caminho para uma maior acumulação num estágio ulterior. Se, portanto, a palavra "globalização" significa alguma coisa relativa à nossa geografia histórica recente, é bem provável que designe uma nova fase exatamente desse mesmo processo intrínseco da produção capitalista do espaço.

De acordo com as interpretações de Alves (2000), Antunes (1999) e Harvey (2004), podemos compreender o processo de reestruturação produtiva do capital como um momento particular de sua própria dinâmica de acumulação, como um processo de mutação no interior do padrão de acumulação capitalista, e não do modo de produção capitalista. Trata-se, conforme Antunes (1999, p.36), de "uma resposta do capital à sua crise estrutural, circunscrita numa esfera fenomênica com a preservação de seus fundamentos essenciais”.

Essa resposta do capital, diante dos empecilhos que se colocam à acumulação do capital, manifesta-se no espaço geográfico por meio de seus “ajustes espaciais” fundamentais, necessários para a concretização dessa lógica historicamente determinada, assim reforçada por Harvey(2004, p.85-6) 
[...] a territorialização e reterritorialização do capitalismo é um processo incessante [...]. Logo, o capitalismo produz uma paisagem geográfica (de relações espaciais, de organização territorial e de sistemas de lugares ligados por meio de uma divisão "global" do trabalho e de funções) apropriada à sua própria dinâmica de acumulação num momento particular de sua história, simplesmente para ter de reduzir a escombros e reconstruir essa paisagem geográfica a fim de acomodar a acumulação num estágio ulterior.

A partir das considerações de Alves (2000), Antunes (1999) e Harvey (2004), podemos pensar nesse processo de reestruturação produtiva do capital como um movimento intrínseco e necessário do próprio processo de reprodução capitalista, historicamente e espacialmente determinado, como parte de um processo mais amplo de mundialização capitalista.

Propõe-se, segundo Harvey (2004, p.88), um processo de produção de desenvolvimento temporal e geográfico desigual dentro de um movimento incessante de territorialização e reterritorialização capitalista.

Este modelo de desenvolvimento temporal e espacialmente diferenciado se manifesta em múltiplas escalas de forma desigual, seja tomando-se, para comparação, a sua concretização entre os países capitalistas avançados e os países ditos de industrialização intermediária, como o Brasil, seja entre regiões de um mesmo país ou entre espaços produtivos de um mesmo setor de atividade, mostrando as particularidades desse processo espacialmente configuradas e articuladas (ANTUNES, 1999, p 32).

Tendo em vista a compreensão e a espacialização dessa lógica, Harvey (2004, p.115) expõe sua discussão a partir do conceito dos desenvolvimentos geográficos desiguais, no qual, segundo o autor, podemos reconhecer as intensas contradições hoje existentes no âmbito das trajetórias capitalistas do processo de globalização:

Os efeitos positivos e negativos variam em intensidade de lugar para lugar. É importante lembrar, por conseguinte, que a globalização sempre foi um projeto implementado e 
endossado por poderes particulares em lugares particulares, poderes que buscaram e obtiveram incríveis benefícios e aumento de sua riqueza e seu poder a partir das liberdades no comércio. Mas é precisamente nesses contextos localizados que as mil e uma oposições à globalização se formam, clamando por alguma maneira de ser, articuladas como um interesse oposicional geral.

No Brasil, a implementação massiva do complexo de reestruturação produtiva está diretamente associada à intensificação da política econômica neoliberal, e a disseminação de seus elementos por parte do Estado e da sociedade brasileira, perfazendo a passagem daquilo que Alves (2000) designou como sendo um “toyotismo restrito”, na década de 1980, incompleto e seleto à área mais dinâmica do capitalismo industrial do Brasil, ou seja, a produção automobilística na região do $\mathrm{ABC}$ paulista, para um "toyotismo sistêmico”, ampliado a outras atividades econômicas e vulgarizado pela sociedade.

No que concerne à incorporação de elementos do modelo toyotista, por parte do atual padrão de acumulação capitalista, convém destacar o aspecto original dessa associação: a captura da subjetividade operária. Segundo Alves (2000):

[...] cabe a ele - o toyotismo - articular, na nova etapa da mundialização do capital, uma operação de novo tipo de captura da subjetividade operaria, uma nova forma organizacional capaz de aprofundar - e dar uma nova qualidade - a subsunção real do trabalho ao capital inscrita na nova forma material do capitalismo da Terceira Revolução Científica e Tecnológica (ALVES, 2000, p.36).

[...] a operação de subsunção da subjetividade operaria pela lógica do capital é algo posto - e reposto- pelo modo de produção capitalista. Só que é com o toyotismo que a captura da subjetividade operária adquire o seu pleno desenvolvimento, um desenvolvimento real e não apenas formal (ALVES, 2000, p.42) 
É a captura da subjetividade operária, por meio de elementos, como os círculos de controle de qualidade, qualificação e treinamento profissional, formas aprimoradas de gestão da produção e do trabalho que vão dar força a um padrão de acumulação do capital, nas mais diversas atividades econômicas, produtivas ou não.

No que se reporta ao setor sucroalcooleiro, o novo complexo de reestruturação produtiva se encontra articulado com os desdobramentos que atingiram a agroindústria canavieira durante a década de 1990.

Nesse período, concretizou-se um processo de desregulamentação da atividade produtiva (BACCARIN, 2005) com o desmonte do órgão de intervenção estatal (Instituto do Açúcar e do Álcool) no governo de Fernando Collor de Mello, possibilitando uma certa flexibilidade das atividades econômicas do setor.

Baccarin (2005, p. 21-5) busca entender as razões do processo de desregulamentação do setor sucroalcooleiro após 1990 e, ao mesmo tempo, analisar a sua estrutura e seu desempenho diante de um contexto que, segundo o autor, é marcado mais por uma nova regulamentação do complexo sucroalcooleiro, tendo em vista a instituição de políticas de compensação pública que acompanharam todo o processo de desregulamentação das atividades sucroalcooleiras.

O fortalecimento dos lobbies no Congresso Nacional e de entidades de classe representativas para defender os interesses do setor, como a Unica (União da Agroindústria Canavieira do Estado de São Paulo), a Abag (Associação Brasileira do Agronegócio), a Abimaq (Associação Brasileira da Indústria de Máquinas e Implementos Agrícolas, promotora das feiras Agrishow pelo país), dentre outras, revela a articulação política, aglutinando os interesses da classe dos grandes usineiros deste país, mesmo levando-se em conta o diferencial produtivo e a dimensão dos seus negócios.

O amparo político estatal não foi deixado de lado, com o dito processo de desregulamentação do setor sucroalcooleiro. Apesar de ser combatido pelos 
discursos em favor da desregulamentação e liberalização de preços de comercialização do açúcar e álcool, as benesses governamentais se fazem presentes, no entanto, inseridos no interior da mesma lógica necessária para a acumulação capitalista do setor econômico. Baccarin (2005, p. 25) justifica a posição de que ocorreu uma nova regulamentação, e não um processo de desregulamentação do setor sucroalcooleiro, apoiado no longo período para liberalização definitiva dos preços dos principais produtos da agroindústria canavieira: nove anos depois de iniciadas as discussões, no início da década.

É importante ressaltar que o mesmo processo de desregulamentação foi gradual, envolvendo periodicamente parte dos produtos e das atividades da agroindústria canavieira. Este processo só não pode ser adiado em função da crise econômica, decorrente da desvalorização cambial da moeda brasileira no início de 1999. Todavia, as negociações futuras, sempre envolveram compensações políticas e econômicas, adequadas às necessidades do lobby dos grandes usineiros.

As políticas adotadas pelo governo no setor de energia provocaram um grande processo de diferenciação interna entre as unidades produtivas de açúcar e álcool, passando a investir na diversificação e na racionalização de seus produtos, marcas do processo de reestruturação produtiva no setor sucroalcooleiro.

Observa-se, no final dos anos 1990, particularmente a partir de 1998, a intensificação das fusões e incorporações de grandes e médias usinas no Brasil, inclusive contando com um elemento novo, no final do século XX: a participação crescente de grupos estrangeiros em associação com grandes empresas nacionais na aquisição de parte destes estabelecimentos.

Dessa aliança, surgiu a joint-venture FDA (Franco Brasileira Açúcar e Álcool), firmada entre o Grupo Cosan, o maior produtor de açúcar e álcool do país, e do mundo, em parceria com a Union DAS (Union des Sucreries e Destilleries Agrícole), a maior cooperativa dos produtores de açúcar e álcool da França e a Sucden (Sucres e Denrees); e grupos nordestinos, principalmente 
de Alagoas e Pernambuco, que se tornaram proprietários de várias usinas no Centro-Sul, como Grupo J. Pessoa e o Grupo Petribu, originários de Pernambuco, e o Grupo Carlos Lyra, de Alagoas. (PASIN \& NEVES, 2002, p. 7)

As fusões e aquisições, verificadas no setor sucroalcooleiro, sinalizam a participação da agroindústria canavieira no processo de reestruturação do capital. De acordo com Pasin \& Neves (2002), houve um crescimento expressivo do setor sucroalcooleiro em relação aos demais setores da economia brasileira, sendo que uma evidência desse fato é a participação das fusões e aquisições da agroindústria canavieira, no conjunto das fusões e aquisições ocorridas no país no final da década de 1990 e início dos anos 2000.

No que concerne às fusões e aquisições no setor sucroalcooleiro, Ana Maria Soares Oliveira (2004, p.59) menciona que, neste processo, o capital sofre um espalhamento do ponto de vista territorial e uma concentração do ponto de vista do controle, com a tendência das pequenas unidades produtoras, com capacidade de produção inferior a 1 milhão de toneladas, se juntarem às empresas maiores. Oliveira (2004) ainda coloca a possibilidade de um grupo seleto de empresas explorar toda a cadeia produtiva sucroalcooleira, resultando desse esforço, a necessidade de se associar ao capital internacional, como o fez o grupo Cosan, aliando-se a empresas francesas que comandam grandes redes de distribuição e industrialização do açúcar no mercado europeu.

Já no que se refere às relações de trabalho no interior da agroindústria canavieira, o estudo de Oliveira (2004, p.84-5) nos mostra que a “imposição pela indústria de um padrão tecnológico e de um novo ritmo ao processo de trabalho na agricultura”, sendo sentida mais de perto por meio da "melhoria da qualidade da matéria-prima e da eficiência do maquinário fabril”, como atestam as pesquisas científicas realizadas por instituições públicas e privadas. 
Como resultado, mais de perto, temos a Genoma da Cana, já referido neste trabalho; assim como o aperfeiçoamento de máquinas e equipamentos voltadas à produção agroindustrial canavieira, coroada anualmente, nos meses de maio, na feira Agrishow, na cidade de Ribeirão Preto.

A intensificação da tecnificação no campo é relativa, abarcando principalmente as grandes unidades processadoras de açúcar e álcool, muitas das quais lançando-se na diversificação e divulgação de novos subprodutos da cadeia produtiva sucroalcooleira. Imbuí-se do discurso ambientalista, vulgarizado pela grande imprensa, como forma de ampliar seus lucros, conquistando mercados seletos, porém altamente recompensadores pelo alto valor agregado atribuído a estes produtos, como, por exemplo, o açúcar orgânico. Trata-se, segundo Oliveira (2003, p. 162-63), da continuidade da lógica de reprodução ampliada do capital sucroalcooleiro adequada ao paradigma da reestruturação produtiva e da acumulação flexível do capital:

[...] Os referenciais que apresentamos como "novos” não passam de maquiagem nos velhos paradigmas que dão sustentação ao processo de acumulação do capital. Mudam-se os meios, mas os fins continuam os mesmos. Os discursos e os processos de produção adquirem conotação ecológica, pautada nos princípios do desenvolvimento sustentável, tornando-se mais um elemento para a sustentação do sistema metabólico e de controle societal do capital.

[...] Dito de outro modo, o processo de reestruturação do capital buscou não somente reorganizar o sucesso produtivo, mas também gestar um projeto que reafirmasse sua hegemonia e dominação societal (OLIVEIRA: 2003, p. 162).

As redefinições tecnológicas pelas quais passa a agricultura canavieira também atingem diferencialmente vários espaços e etapas do processo produtivo. Quanto ao último, a incorporação do progresso técnico no campo, ocorre desde a preparação do solo, passando pelo plantio, tratos culturais e especialmente a colheita, fase que demanda um grande número de trabalhadores, especialmente trabalhadores migrantes. Estas redefinições não 
se restringem apenas à esfera tecnológica, abrangendo e relacionando-se com outras esferas como a da reorganização das relações de trabalho e a produção no campo apoiada em práticas empresariais condizentes com as formas vigentes de reprodução do capital nos dias de hoje.

Na etapa do plantio da cana-de-açúcar em terras da Usina Santa Rita, por exemplo, as relações de trabalho são ditadas pelo ritmo da máquina, do caminhão carregado de tollets de cana, como se pode ver na figura 25.

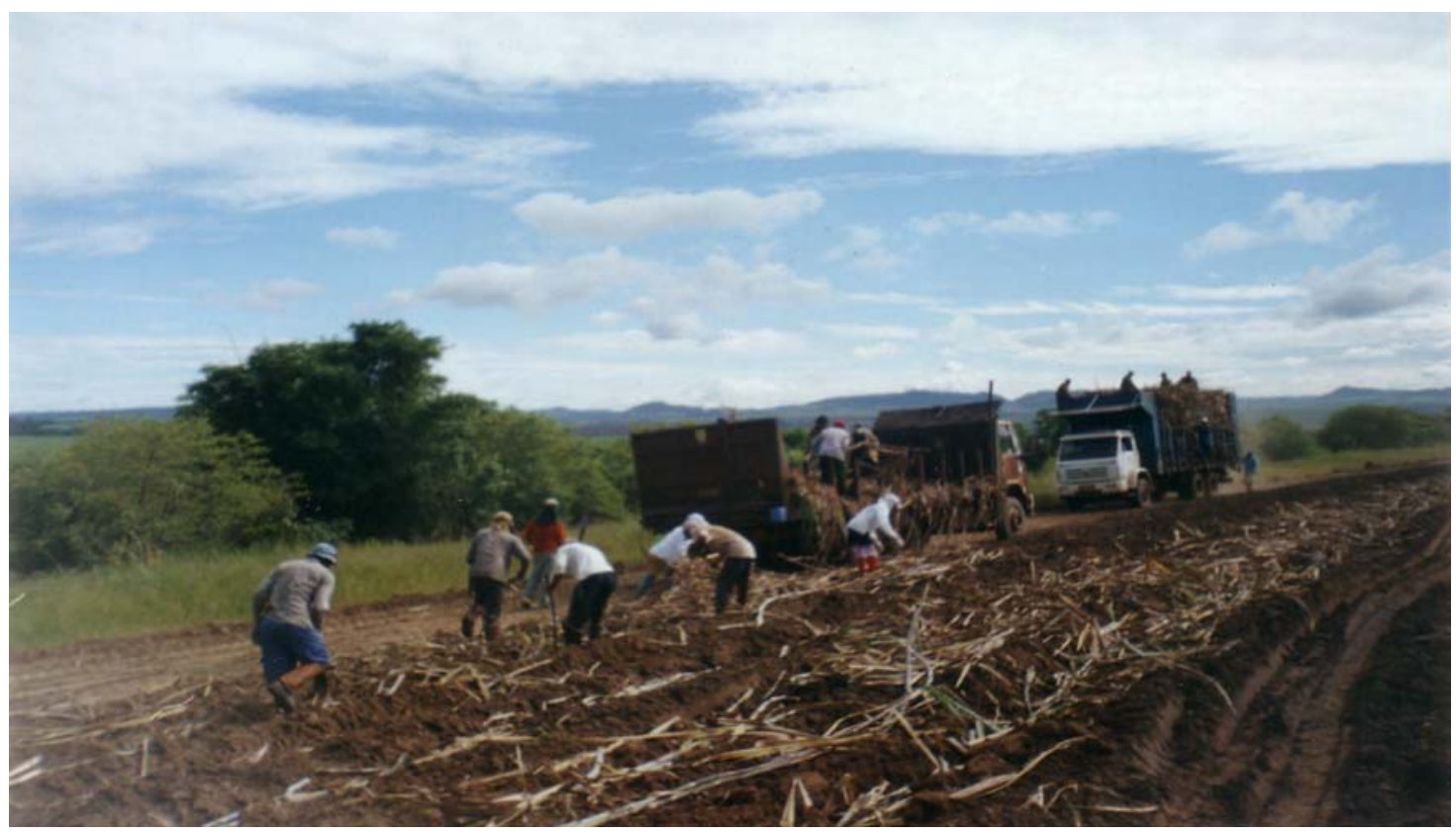

Figura 25 - Plantio de cana-de-açúcar. Antiga seção Santa Sofia da Fazenda Amália, hoje, terras pertencentes à Usina Santa Rita, no município de Santa Rosa de Viterbo / SP.

(Autor: André Eduardo Ribeiro da Silva, março de 2006).

No processo de trabalho no plantio da gramínea, temos a participação dos "lançadores" (trabalhadores que jogam os tollets de cana dos caminhões carregados) e os “picadores” (que são aqueles trabalhadores que cortam os tollets de cana em pedaços menores, de 2 a 3 centímetros, e os lançam nos sulcos feitos pelas máquinas, na etapa anterior, de preparação dos solos, fase totalmente mecanizada), atividades que exigem um acentuado esforço ergonômico para a execução do trabalho. Na figura 25, num primeiro plano, 
nota-se a presença de uma trabalhadora nessa atividade, a única dessa turma, registro revelador da diminuição do emprego de mulheres em várias fases da atividade produtiva nos canaviais. O caminhão canavieiro é de empresa terceirizada pela usina, elemento importante do processo de reestruturação produtiva que atinge a lavoura canavieira paulista. No canto direito da fotografia, nota-se um caminhão carregado de tollets de cana para o plantio da gramínea, bem como o "encontro” de turmas no carreador, momento revelador da divisão espacial do trabalho no espaço produtivo. Também se percebem as demandas do capital, antecedendo a colheita canavieira: caminhão de tollets de cana, vazio vai, caminhão carregado de tollets cheio vem.

É, no entanto, na colheita da gramínea que se faz sentir, os maiores efeitos da expansão da mecanização na agroindústria canavieira. Desde a segunda metade da década de 1960, a maior parte da cana colhida no país, se faz a partir do corte manual da cana queimada, seguindo o sistema de "cinco ruas”. O corte mecânico da gramínea seja ela crua ou queimada, adotado a partir da década de 1970, ganhou um novo salto na metade dos anos 1980, segundo Alves (1991) impelido pelas greves de trabalhadores rurais que paralisaram a produção agroindustrial de várias empresas sucroalcooleiras do estado de São Paulo.

A mecanização da cultura de cana-de-açúcar foi, portanto, um instrumento utilizado pelos usineiros paulistas como barganha política na contenção do movimento dos trabalhadores da agroindústria canavieira, com o fito de pressionar os mesmos, com a ameaça da perda de seus postos de trabalho para as máquinas nos talhões de cana.

Mesmo com a ameaça constante da substituição do cortador manual pelas máquinas, o custo dispendido pelas usinas, na aquisição e manutenção das mesmas, era muito superior à remuneração oferecida ao trabalhador canavieiro. Desta forma, a maior parte dos canaviais paulistas continuou sendo queimada e colhida manualmente e as máquinas, mesmo representando uma ameaça aos empregos na agricultura canavieira, permaneceram, na maior parte 
das unidades produtoras, conforme expressão de Graziano da Silva (1981) como "máquinas de vitrine”.

Só foi, contudo, nos anos 1990, com a incorporação de novos elementos na produção sucroalcooleira nacional, no processo de reestruturação produtiva no setor, que a mecanização foi acelerada nos canaviais do Brasil, envolvendo, primeiramente, as unidades agroindustriais mais capitalizadas que dispunham de melhores possibilidades de se adequar aos parâmetros internacionais de produção colocados para o setor econômico.

O processo de reestruturação serviu também para acirrar a diferenciação produtiva interna entre as unidades agroindustriais do complexo canavieiro, num momento de discussão da desregulamentação do mesmo.

A colheita da cana-de-açúcar, realizada em sua maior parte à partir da cana queimada, colhida manualmente, passava também a ser feita por meio de três outros modos: de forma manual, a partir da cana crua; ou mecanicamente, a partir da cana queimada ou crua. De acordo com Oliveira (2003, p.5), a principal modalidade de corte da gramínea que apresentou um notável crescimento na lavoura canavieira, em particular, na do estado de São Paulo, foi o corte mecânico sobre a cana crua.

A partir da segunda metade da década de 1990, as alegações de que a queima da palha da cana-de-açucar provoca efeitos maléficos sobre o meio ambiente e a sua regulamentação através do Decreto no. 42.056/97, bem como o "barateamento" das máquinas e maior aperfeiçoamento técnico, fez com que o uso da colheitadeira se ampliasse nas empresas de médio e grande porte e atingisse também as pequenas empresas. Conseqüentemente, houve a intensificação do corte mecanizado da cana crua.

Na safra paulista de 2006/2007,ocorreu uma decisão inédita por parte da Secretaria Estadual do Meio Ambiente, em consonância com a legislação que prevê a substituição gradual das queimadas e do corte manual da cana até 
2031 (Lei ${ }^{\circ}$. 11.241, de 19 de setembro de 2002), favorecendo o corte da cana crua.

A proibição da queima da palha nos canaviais paulistas, durante algumas semanas do inverno passado, decorre da diminuição das taxas de umidade do ar em várias áreas canavieiras do estado, em razão dos efeitos nocivos para a saúde humana, acentuados pela secura do ar e, conseqüentemente, do aumento dos casos de doenças do aparelho respiratório humano, exatamente no pico da safra no estado de São Paulo. Nas unidades agroindustriais mais capitalizadas, com elevado emprego do corte mecanizado da cana crua, essa decisão foi cumprida sem maiores dificuldades.

Contudo, para uma parte importante dos plantadores de cana paulistas, a submissão às normas da instituição estatal representou a adoção da colheita manual dos canaviais, posição que significou um aumento do dispêndio energético e desgaste físico do trabalhador, apesar da maior remuneração oferecida pelo pagamento da cana colhida, como pode ser visualizado na figura abaixo.

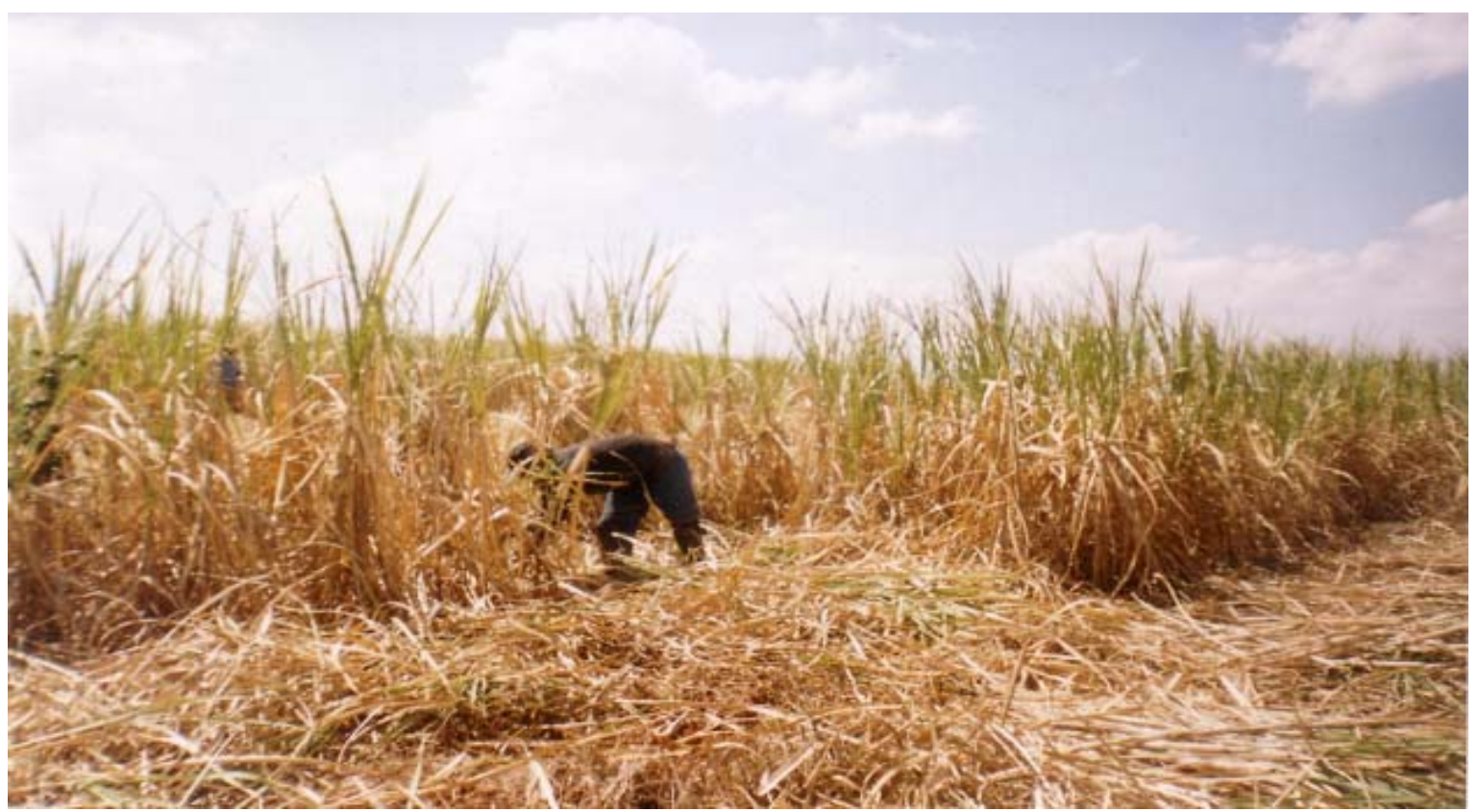

Figura 26 - Cana manual da cana crua: discussão social prolongada, desgaste garantido do trabalhador. Terras arrendadas da Usina Santa Rita, no município de São Simão/SP.

(Autor: André Eduardo Ribeiro da Silva, setembro de 2006). 
Quanto à colheita da cana-de-açúcar, a mecanização nos canaviais cultivados pela Usina Ibirá é maior em relação aos canaviais de fornecedores, arrendadores ou parceiros da unidade processadora. As diferentes taxas de mecanização da colheita, que se encontra em torno de $78 \%$ em terras arrendadas e controladas diretamente pela Usina Ibirá, recuam para 57\%, nas propriedades dos fornecedores da gramínea para a usina. Levando-se em conta a área total colhida, esses dados apontam para o diferencial técnico existente entre os canaviais de fornecedores e os que são na maior parte do processo produtivo controlado pela própria usina.

Segundo informações obtidas por meio de conversas rápidas com os trabalhadores responsáveis pela gestão do trabalho nos canaviais moídos na Usina Santa Rita, nas imediações da Fazenda Amália, toda a cana é queimada e colhida de forma manual. Verifica-se, segundo as informações supracitadas, um diferencial quanto ao processo de mecanização nos canaviais destinados às usinas Ibirá e Santa Rita, com uma considerável vantagem da primeira.

No entanto, a face oculta da agroindústria canavieira revela-se por meio da análise das condições de vida e trabalho dos canavieiros, em especial dos cortadores de cana, envolvidos nas lides agrícolas que ocupam a maior parte do tempo e da ocupação da maior parte dos trabalhadores ao longo do ano. É no corte da cana que a tecnificação passa a dirigir de forma mais contundente o ritmo e o conteúdo do desemprego nos talhões da gramínea. (OLIVEIRA, 2003 p. 132).

Tem-se em cena, de acordo com Ana Maria Soares Oliveira (2004, p.82):

o processo de reestruturação produtiva, permeado pela desregulamentação, por diferentes formas de superexploração do trabalho, por novas formas de gestão e de controle do processo de produção e de trabalho, pela redução de custos e diversificação de produtos, etc., contribuindo para a constituição de um novo reordenamento territorial e produtivo do capital sucroalcooleiro, que se expressa diferencialmente, tanto entre as empresas sucroalcooleiras, 
como entre as várias frações do território brasileiro e, particularmente de São Paulo.

Em nosso estudo, podemos perceber a materialização espacial do processo de reestruturação produtiva por meio das práticas empreendidas no campo por duas usinas de açúcar e álcool que possuem plantações de cana-deaçúcar numa área territorial que até o início da década de 1990, fazia parte da então Fazenda Amália, propriedade da usina de mesmo nome controlada pelo Grupo Matarazzo.

A produção canavieira, territorialmente monopolizada e dominada por uma única usina, teve com o anúncio do pedido de concordata da mesma, no início dos anos 1990, importantes implicações sócio-espaciais.

As mudanças foram mais sensíveis no que se refere às formas de organização e composição da força-de-trabalho, especialmente no corte de cana, e à configuração fundiária, por meio da fragmentação das terras da Fazenda Amália, da qual parte foi vendida, parte foi tomada para o pagamento de dívidas e arrendada para outras usinas sediadas na região de Ribeirão Preto.

Como já explicitado anteriormente, a partir de 1998, com um novo arrendamento da usina e de suas terras para a Usina Da Pedra, as práticas desse processo de reestruturação produtiva e do trabalho se intensificam e sua abrangência espacial atinge todo o complexo agroindustrial, seja na seção administrativa da usina, em sua parte industrial ou agrícola.

Podemos precisar a abrangência territorial do processo de reestruturação produtiva na agricultura canavieira, por meio da terceirização de serviços para colheita da cana, como carregamento e transporte ${ }^{1}$, a aplicação de maturadores nos canaviais por aviões agrícolas (abreviando o corte da cana entre 35 e 55 dias e garantindo um rendimento de 6 a 10 quilos a

${ }^{1}$ Cf. IBIRÁ terceiriza serviços. O Jornalzão, Santa Rosa de Viterbo, Ano 4, nº.144, p. 1, 25 abr.1998 
mais por tonelada de cana moída²) até a utilização de colhedeiras (duas da Usina Ibirá, próximas ao perímetro urbano da cidade ${ }^{3}$ ) e maquinários agrícolas modernos na lavoura, permitindo uma maior produtividade e diminuição dos custos de produção como aponta a matéria jornalística abaixo:

A safra na usina Ibirá começa no próximo dia 2 de maio e vai até meados de novembro e a previsão é de moer 1.250 toneladas de cana, produzir 56 milhões de litros de álcool e 1 milhão e 600 mil sacas de açúcar, um pouco mais do que o que foi produzido na safra passada. Dessa produção, 30 milhões de litros de álcool hidratado especial H1-vão abastecer o Japão e a Coréia.[...] A área industrial da usina passou por reformulações desde a safra passada com melhoramentos na destilaria e na fábrica de açúcar. Segundo informa o diretor industrial da Ibirá, a indústria vem passando por reformulações e adequações desde que foi arrendada do grupo Matarazzo em 1998, com instalação de equipamentos modernos e tecnologia de ponta. "Nossas metas são a segurança industrial para todos os trabalhadores, manter a qualidade do produto entregue ao consumidor e satisfação dos clientes. Acabou a época do engenho, hoje, toda usina é uma produtora de alimentos [...]A vinhaça que antigamente ficava estocada em lagoas é usada na adubação e a terra da lavagem da cana, a torta de filtro é usada na recuperação do solo. E o bagaço, que era descartado, é inteiramente usado na

${ }^{2}$ A explicação é que a pulverização do maturador está sendo feita por uma empresa de aviação agrícola de Ribeirão Preto com um avião monomotor de 600 hp, com capacidade para despejar 1.500 litros do produto no canavial em meia hora de vôo rasante. O avião pulveriza cerca de 150 hectares por hora e é americano. Segundo o piloto, o serviço custa 300 mil dólares. Dissolvido na água - O maturador é misturado na água com um pacote plástico que se dissolve automaticamente junto com o produto e a quantidade segue receita do agrônomo responsável. A água vem em caminhão pipa da usina. O piloto do avião, Marcelo Amaral, explica que a aplicação só pode ser feita com temperatura inferior a 30 graus e umidade do ar de 50\%. "Por isso, só voamos de manhã e de tarde, porque a temperatura atinge o nível que garante a durabilidade do maturador". Ele explica ainda que com chuva o maturador não pode ser aplicado porque vai se dissolver na água e não fará efeito. (Disponível em <http://www.ojornalzao.com.br> Acesso em 18 abr.2005.

${ }^{3}$ Cf SAFRA da Ibirá começa dia 24 O Jornalzão Santa Rosa de Viterbo, ano 5, $\mathrm{n}^{0}$. 177, p.5, 08 mai.1999. 
geração de energia. A usina produz toda a energia que consome na safra Atualmente a Ibirá gera 5MW hora de energia.

(Disponível em <http://www.ojornalzao.com.br> Acesso em 25 abr.2006)

O processo de melhoramento técnico, realizado pela Usina Ibirá,fornece elementos para a compreensão da reestruturação produtiva que, de diversas maneiras atinge, o espaço canavieiro pertencente à Fazenda Amália.

Outros elementos presentes na matéria jornalística atentam para a maximização do aproveitamento da matéria-prima, fato que não é novo, mas corrobora o grau de integração do complexo agroindustrial canavieiro.

Temos, deste modo, a agroindústria canavieira como um exemplo concreto de territorialização de um importante complexo agroindustrial, devido ao intenso grau de interdependência entre as atividades agrícola e industrial sucroalcooleiras:

Vê-se, portanto, que não há mais como dissociar o processo de racionalização ditado pela intensificação da mecanização da lavoura, principalmente na colheita, com as determinações e demandas da unidade fabril, que governa o conjunto das operações agroindustriais.

Entendido assim, de forma articulada (lavoura e indústria processadora), é possível admitir que o "açúcar se faz no campo", ou seja, "o processo industrial apenas recupera a sacarose já presente na planta, mesmo que seja possível alcançar ganhos significativos no rendimento industrial através do aumento da eficiência na extração" e demais etapas do processo (THOMAZ JR., 2002, p.147, 149).

ELIAS (2003, p. 140) traz considerações importantes a respeito da participação das agroindústrias na organização sócio-espacial e territorial na região de Ribeirão Preto:

Assim, embora a agroindústria sempre tenha sido o principal gênero industrial da região, uma parte considerável do setor chega aos dias de hoje totalmente modernizada, constituindo o motor de inúmeras outras atividades em todos os demais 
setores econômicos. Da mesma forma, são responsáveis por um processo corporativo de organização do espaço, uma vez que conseguem comandar a organização do espaço agrícola e urbano da região de Ribeirão Preto de acordo com seus interesses econômicos.

Por meio da incorporarão dos principais conceitos de Milton Santos, principalmente a partir da categoria fundamental de meio técnico-científicoinformacional, Elias (2003, p.19-20) propõe uma leitura da produção do território da região de Ribeirão Preto, por meio de elementos técnicos e sociais que redefinem particularmente seu espaço agropecuário e a relação desse processo historicamente determinado e construído com os ditames da ordem global hegemônica no contexto presente.

Dessa forma, a autora contribui para uma leitura espacial da difusão e socialização das técnicas como elemento fundamental para a compreensão do processo de produção do território, segundo uma lógica de reprodução e reestruturação produtiva do capital, condizentes com o movimento de globalização da economia e da aceleração contemporânea. É a imposição territorial do processo de desenvolvimento do capitalismo no presente, de territorialização do capital e de suas forças produtivas de forma plena. Nas palavras da autora:

Enfatiza [o seu trabalho], portanto, o processo de organização de novo modelo econômico, social e territorial de produção da agricultura, correlacionando condições locais em face dos imperativos da ordem global hegemônica, a partir da inserção da produção regional nos circuitos espaciais de produção e nos círculos de cooperação agropecuária e agroindustrial globalizadas (ELIAS, 2003, p.19-20).

Concordamos com a autora na medida em que, assim como na região de Ribeirão Preto, verificamos, em nossa área de estudo, um processo de produção do território voltado e comandado principalmente pela agroindústria sucroalcooleira. 
O capital agroindustrial canavieiro se territorializa, controla e domina a produção agrícola e industrial além do domínio da terra apropriando-se do lucro agroindustrial e da renda da terra, impondo o seu modelo de desenvolvimento.

Particularmente no município de Santa Rosa de Viterbo e na área canavieira da antiga Fazenda Amália, o processo de reestruturação produtiva da agroindústria canavieira veio acompanhado por uma diminuição dos postos de trabalho, pelo desemprego e precarização de um trabalho já bastante precarizado, provocando várias implicações sociais para os trabalhadores da lavoura canavieira. É o que explicaremos a seguir.

\subsection{As Relações de Trabalho nos Canaviais}

A intensificação do processo de mecanização do corte de cana e modificações na forma de organização do trabalho nos canaviais vem produzindo um grande número de trabalhadores demitidos, particularmente desde o início da década de 1990.

Para aqueles que mantiveram seus empregos no campo, as tendências dp processo de reestruturação produtiva no campo vêm sendo acompanhadas por grandes transformações, como a intensificação do ritmo e flexibilização das jornadas, permitindo a elevação da produtividade do trabalho e conseqüentemente a precarização do mesmo.

Antunes (1999, p.34), ao refletir sobre as dimensões da crise estrutural do capital, aponta manifestações de um sentido destrutivo dessa lógica de reorganização do capital:

Como tem sido enfatizado insistentemente por diversos autores, o capital, no uso crescente do incremento tecnológico, como modalidade para aumentar a produtividade, também "necessariamente implica crises, exploração, pobreza, desemprego, destruição do meio ambiente e da natureza”, entre tantas formas destrutivas 
(Carcheti,1997:73). Desemprego em dimensão estrutural, precarização do trabalho de modo ampliado e destruição da natureza em escala globalizada tornaram-se traços constitutivos dessa fase da reestruturação produtiva do capital.

O sentido destrutivo da lógica do capital faz sentir-se na lavoura canavieira, principalmente por meio da imposição pelas usinas de médias de produtividade individual no corte manual de cana, que hoje de modo geral gira em torno de 12 toneladas/cortador/dia. As médias de produção diária ainda podem ser escamoteadas pelos métodos de pesagem da cana, não condizentes com a quantidade real de cana cortada pelo trabalhador, de acordo com o sistema do campeão.

Tais “metas” de produção diária, impostas aos trabalhadores canavieiros, sobretudo aos cortadores de cana, variam de usina para usina na região de Ribeirão Preto, sendo também, indicativa da intensificação do processo de mecanização no corte de cana.

A cana picada pelas colhedeiras e carregadores mecânicos é a plantada nos talhões mais planos e em geral é a que possue melhor cotação para o corte. É a chamada "cana velinha”, de colmos eretos, cuja regularidade de crescimento dos colmos possibilita que o trabalhador colha um maior número de toneladas durante a jornada de trabalho (vários colmos abraçados e ceifados de uma única vez) (RUMIN, 2004, p.144).

O corte mecânico da cana crua, sobretudo nos terrenos movimentados, retira as melhores possibilidades de ganho do trabalhador, além de aumentar o dispêndio físico e energético do mesmo, principalmente por meio da curvatura acentuada da coluna vertebral nos terrenos de maior inclinação, em aclives de curvas de nível, bem como no corte da cana "pé-de-rolo”, em que os vários colmos não podem ser ceifados de uma única vez.

Nota-se uma relação estreita entre as características da cana colhida e as posturas exigidas para a execução do trabalho, relação que se reflete no resultado da empreita do trabalhador e no agravamento de suas condições de 
trabalho, de vida e de saúde na lavoura canavieira, de acordo com Rumin (2004, p.139- 49).

Nas palavras de um entrevistado:

É a que nós ganha mais dinheiro [cana em pé]. É das máquina, é mais favorecida para as máquina [...] As cana boa é das máquina. As beira de talhão é nossa, que é o lugar que as máquina, as bonita não vai, as pó-de-arroz. Nós vai. [Póde-arroz é o nome que vocês dão às colhedeiras?] Não é colhedeira, mas nós chama elas de pó de arroz, os trabalhador gosta de falar: olha as pó-de-arroz. Esses aqui são os marajá (Trabalhador rural da Usina Ibirá. Depoimento colhido em 3 abr. 2006).

Os melhores solos deste país estão nas mãos dos usineiros. As melhores canas são para as colheitadeiras, as “pó de arroz”. Os piores talhões, as piores canas são cortadas pelos trabalhadores rurais. Nota-se apenas nesse trecho um quadro de degradação das relações de trabalho no corte da cana, relação social bastante precária já nas primeiras décadas do século passado (IANNI, 1984, p. 42), estendendo-se para seu espaço reprodutivo, repercutindo nas suas condições de vida e de sua família.

Os trabalhadores canavieiros da antiga Fazenda Amália, residentes na cidade de Santa Rosa de Viterbo, sejam eles “do lugar” ou migrantes, que laboram nas terras controladas pelas usinas indicadas, trabalham de acordo com uma média de produção que varia de 8 a 12 toneladas/trabalhador/dia nas duas usinas.

É uma base que eles faz. Eles somam todos os dias do mês anterior, quanto você tirou, aí chega por exemplo, naquele mês, o mês fecha dia 20, 21, aí eles somam tudo e vê quanto você tirou por dia e quantas toneladas a você pertenceu [...] Aí quando eles vê que você não está mais atingindo, aí eles procuram saber. Vem um cara da usina, senta, conversa com a gente quer saber o que é que está acontecendo na sua casa, porque você está doente, o teu dia-a-dia com a família, eles especulam para poder tentar ajudar [...]. Mas tem dia que eu 
atinjo mais, tem dia que eu atinjo até onze (Trabalhador rural da Usina Ibirá. Depoimento colhido em 3 abr. 2006).

As condições de trabalho, marcadas pela exigência dessas médias de produção diária, são agravadas pelo sistema de folgas, o chamado sistema “cinco por um” na Usina Ibirá (a turma trabalha cinco dias e folga um).

Por esse sistema de trabalho, o dia de descanso, garantido por lei aos sábados e domingos, não é respeitado ferindo a Norma Regulamentadora $31^{4}$. De acordo com um trabalhador:

Você vê, o trabalhador rural não tem lugar para ir. O divertimento dele é no sábado, do sábado para o domingo. Chega no sábado ele vai procurar algo, ou ele vai caçar uma cama, ou ele vai descansar. Chega no domingo, ele vai querer ver a família. A família, que nem nós aqui mesmo, reúne todo mundo aqui da cidade, que nem você tem família, todo domingo você quer ficar com a sua família. Agora, no período da safra, eles tiram isso. Eles jogam cinco por um. Chega na época cinco por um, as folgas caem na segunda. Segunda-feira você vai ao forró? Você vai passear? Você vai à casa do seu irmão? Você vai a casa dele? Você não vai achar ninguém. Aonde você vai? Ah é bom porque eu vou ao médico! Chega no médico você fica até três horas, quatro horas da tarde. Sai do médico, você vai cedo e você volta às quatro. No outro dia você tem que trabalhar. No dia da tua folga você ficou ocupado. É isso que está estressando mais os trabalhador, eu tenho certeza, que nem nós sempre conversa um com o outro, é isso que está estressando mais os trabalhador, é isso...

(Trabalhador rural da Usina Ibirá. Depoimento colhido em 3 abr. 2006).

O sistema “cinco por um” fere a legislação trabalhista, vindo a se somar aos inúmeros mecanismos de superexploração no espaço produtivo e reprodutivo desses sujeitos sociais.

\footnotetext{
${ }^{4}$ Cf.Pauta de Reivindicações Data Base Setor Canavieiro, 2006. Mimeografado.
} 
O processo de terceirização é uma das marcas da reestruturação da produção e do trabalho que caracterizam o desenvolvimento do capitalismo, atingindo também as relações de trabalho na lavoura canavieira.

Nos canaviais controlados pela Usina Santa Rita, nas terras que compunham a Fazenda Amália (Fazendinha, Sede I, Sede II, Santa Sofia, Bananal, no município de Santa Rosa de Viterbo; Boa Vista I, Boa Vista II, Parazito, São Lourenço, no município de São Simão; Cachoeira II, Graciosa, Alambari, no município de Cajuru; Baixão, no município de Serra Azul), observamos a concretização de uma mesma lógica, embora espacialmente conformada por meio de elementos, como a intensificação da contratação de empresas terceiras para a execução de atividades, antes, estruturadas pelo setor administrativo das usinas, como sugere a menção abaixo:

Na última terça-feira [15 mai.2002], a empreiteira Master, de Sertãozinho, já cortava cana nas imediações da cidade, para ser transportada até Santa Rita do Passa Quatro:

“- Ajustamos duas turmas de Santa Rosa para o corte. Damos preferência para o pessoal da cidade. É mais fácil para nós e é melhor para a cidade. Os operadores de máquinas vieram de Sertãozinho" - disse Valdir de Oliveira, 51 anos, gerente da Master. Segundo ele, está previsto o transporte de $400 \mathrm{mil}$ toneladas de cana de Santa Rosa para Santa Rita do Passa Quatro. O transporte, em caminhões zero $\mathrm{Km}$, está sendo feito pela empresa Buck.”

(Fonte: SANTA Rita leva 400 mil toneladas de cana. $O$ Jornalzão, Santa Rosa de Viterbo, ano 8, n 331, p.7, 18 mai. 2002).

Na lavoura, o fato é constatado, conforme indicado na citação acima, seja por meio da atuação de empreiteiras de mão-de-obra provenientes de outros municípios, ou por meio da contratação de empresas nas etapas de transporte e operação de máquinas no espaço de produção da matéria-prima a ser consumida nas usinas. Temos ainda, a atuação dos "gatos" residentes na

${ }^{5}$ COMUNICADO de queima controlada O Jornalzão, Santa Rosa de Viterbo, ano $\mathbf{x x}, \mathrm{n}^{\circ} \mathbf{x x}$, p.26, $1^{\circ}$. abr. 2006. 
cidade de Santa Rosa de Viterbo, que arregimentam turmas para a colheita de cana nas usinas Santa Rita e Ibirá ou para empresas canavieiras como a Central Energética Moreno, sediada no município vizinho de Luiz Antônio, e a Usina Nova União, em Serrana.

Mesmo que as atividades terceirizadas utilizem a força de trabalho "local”, os novos arranjos estruturais que permitem uma maior flexibilidade das relações e dos direitos trabalhistas, assim como a elevação da produtividade do trabalho e da precariedade dos contratos dos mesmos, configura em outras bases o processo de super-exploração do trabalho e a extração contínua de mais-valia, resultando num processo de desemprego estrutural, que atinge parte significativa dessa classe que vive do trabalho (ANTUNES, 1999).

Para onde foram os trabalhadores e trabalhadoras da lavoura canavieira, sobretudo os cortadores de cana residentes temporária ou permanentemente na cidade de Santa Rosa de Viterbo?

De acordo com a ex-presidente do Sindicato dos Trabalhadores Rurais de Santa Rosa de Viterbo, Edna Clemente ${ }^{6}$, parcela da mão-de-obra “local” dispensada na lavoura foi absorvida por fábricas sediadas na Fazenda Amália, como a indústria de papel, denominada hoje, Rio Pardo Papel e Celulose S.A, e a fábrica de sabonetes IMODSA (Indústria Matarazzo de Óleos e Derivados), sendo a última ainda propriedade do grupo Matarazzo.

Pensamos que mesmo com a absorção por parte dessas empresas do contigente da força de trabalho dispensada das atividades laborais dos canaviais da antiga Fazenda Amália, essa assimilação não foi o suficiente.

Outra parte destes trabalhadores também foram absorvidos em outras usinas da região, mas também em quantidade insuficiente para suprir a

${ }^{6}$ Cf. SILVA, André Eduardo Ribeiro da. A Territorialização da Agroindústria Canavieira: a antiga Usina Amália em Santa Rosa de Viterbo/SP. Trabalho de Conclusão de Curso em Geografia. São Paulo: FFLCH/USP, 2004, p. 22 
diminuição dos empregos, pois muitas dessas empresas passam por um processo semelhante de reestruturação das relações de trabalho e de produção, como pode ser notado, no cartaz da página seguinte, retirado do guichê de uma casa lotérica no início do ano passado(17 jan. 2006), anunciando o início de uma pré-seleção para preenchimento de vários cargos durante a safra da canade-açúcar na Central Energética Moreno, sediada no município vizinho de Luiz Antônio.

Chama a atenção, no cartaz, a distinção que a empresa faz entre aqueles que trabalharam e não trabalharam na safra passada, assim como entre aqueles que nunca trabalharam na empresa.

O motivo do “fichamento" diferencial, aliás, prática comum adotada por muitas usinas, e efetivada por meio de seu escritório, visa o controle sobre o trabalhador, selecionando os "bons" e rejeitando aqueles que tem o nome na “lista negra”, conforme nos indica Silva (1999, p.141-49)

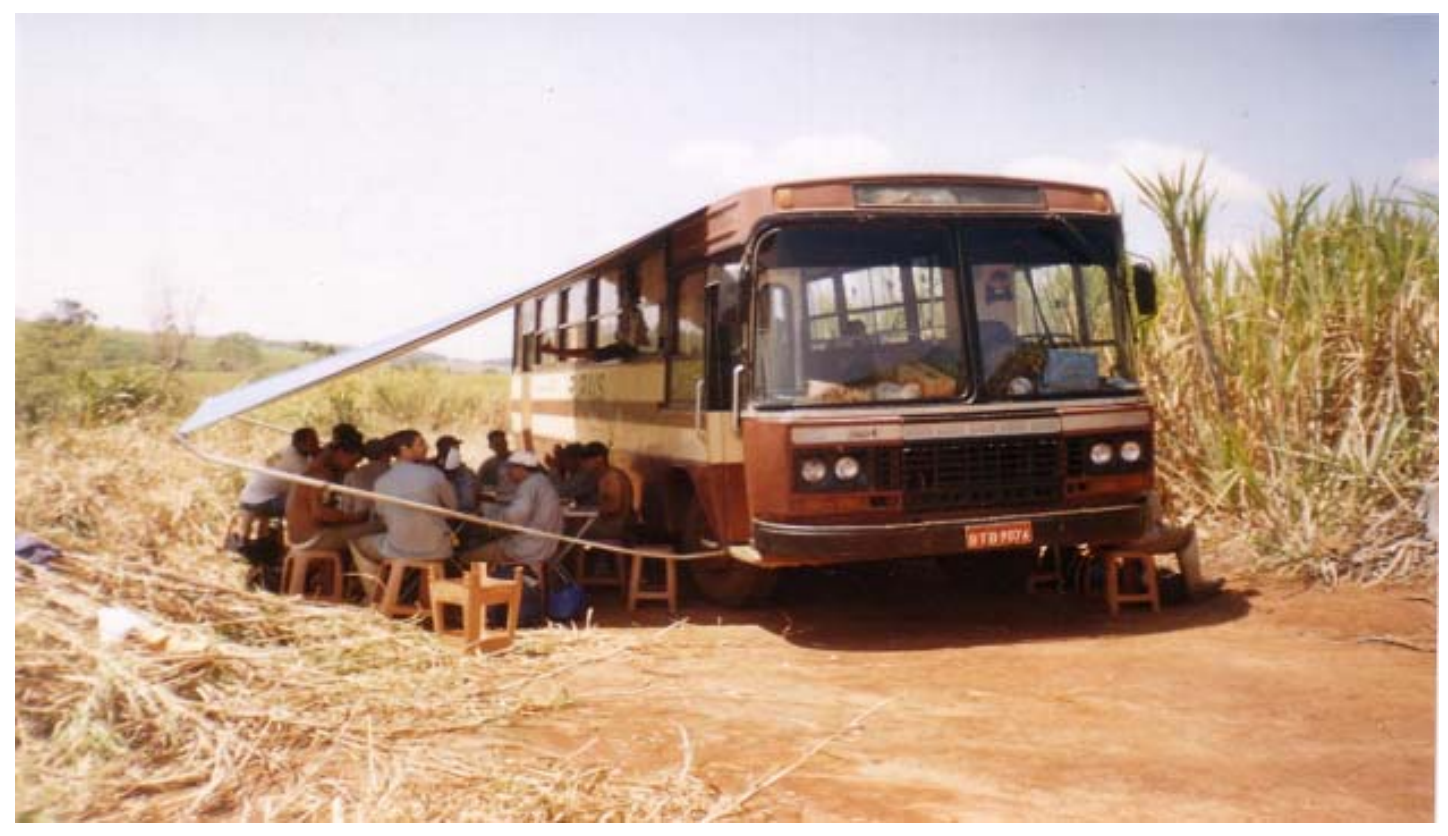

Figura 27 - Trabalhadores do "reflorestamento" da Usina Santa Rita, município de Santa Rosa de Viterbo. As “queimas (des)controladas”da palha da cana provocaram a perda de vários hectares dos poucos refúgios florestais, dentre eles a Mata da Graciosa, entre os municípios de Cajuru e Santa Cruz da Esperança. A usina foi poupada e a pesada multa pelas infrações ambientais gerou uma outra categoria de trabalhadores rurais da agroindústria canavieira.

(Autor: André Eduardo Ribeiro da Silva, setembro de 2006). 
Cartaz da Usina Moreno 
Apoiado em depoimentos de alguns trabalhadores rurais, coletados em pesquisa de campo, pudemos constatar a existência de uma migração sazonal, e para muitos, definitiva, de parte dos trabalhadores, sejam eles cortadores de cana, guincheiros e até fiscais, que tiveram seus empregos tomados nos canaviais da Fazenda Amália.

Muitos dos trabalhadores migraram temporariamente para outros municípios canavieiros no estado de São Paulo, outros vão e vem diariamente para Santa Rosa de Viterbo, transitando de um município para outro, de uma cultura para outra, perfazendo uma mobilidade precária. Vejamos algumas dessas experiências.

Uma moradora do bairro Nosso Teto, conta que além das experiências na lide nos canaviais, também se dedicou ao labor em outras culturas agrícolas, sobretudo no período da entressafra da cana, período designado pelos canavieiros como a época da "parada", de pouco trabalho e de muito desemprego na lavoura da gramínea

No período da entressafra, que geralmente se estende do mês de dezembro a meados de abril ou maio do próximo ano, muitos trabalhadores, aproveitando-se da demanda de serviços em outras culturas agrícolas, são arregimentados por empreiteiros locais para os pomares de laranja, para os cafezais e plantações de amendoim em áreas próximas do município de Santa Rosa de Viterbo.

Também apontou em seu depoimento que trabalhou nos laranjais numa área próxima ao município de Tambaú, na colheita e na carpa dos pomares, na colheita do café e na "roça de amendoim".

Segundo a depoente, o trabalho na colheita do amendoim, trata-se do pior de todos os trabalhos agrícolas de que participou: "O trabalhador tem que trabalhar abaixado durante três, quatro meses por ano com dor nas cadeiras e o ganho era péssimo R\$0,03 o metro”. Hoje, está desempregada, aguardando o início da safra da Usina Santa Rita. (Depoimento coletado em 8 mar.2006). 
Temos o depoimento de outro trabalhador, 40 anos, que acumulou, durante a vida, os cargos de fiscal e tratorista na lavoura canavieira. Trabalhou na safra de cana-de-açúcar doze anos como "fixo", durante a safra e na entressafra. $\mathrm{O}$ depoente começou a trabalhar como fiscal da lavoura em 1989, atividade que exerceu até 1991 na Usina Amália. De 1992 a 2002, trabalhou como fiscal na Usina Ipiranga, sediada em Descalvado, função que dividia com mais um trabalhador, também oriundo de Santa Rosa de Viterbo. Em 2003, trabalhou como tratorista na Usina São Martinho, instalada no município de Pradópolis e, desde 2004, fez duas safras pela Usina Santa Rita Na safra 2005/2006, ele não foi chamado para trabalhar, estando desempregado. Vivia de "bicos" até o inicio da safra, prevista para o início de abril deste ano. (Depoimento colhido em 7 mar.2006)

Um outro trabalhador, 24 anos, morador do bairro Nosso Teto, começou a trabalhar no corte de cana a partir dos 16 anos. Atualmente, exerce a função de guincheiro nos canaviais da Fazenda Amália. Trabalhou também na Usina Moreno, de forma terceirizada nas terras da família de usineiros, no noroeste do estado. No tempo em que trabalhou longe de casa, viveu em uma casa alugada com outras seis pessoas. (Depoimento colhido em 8 mar.2006)

Estes depoimentos vão ao encontro das reflexões de Silva (2001, p. 301) que, por meio de suas pesquisas, na região de Ribeirão Preto, também constatou a ocorrência de fluxos migratórios envolvendo trabalhadores residentes em várias cidades situadas na "mancha canavieira” dessa região:

No que tange aos residentes nesta região, muitos também estão migrando para outros lugares. Nos últimos anos, tem-se observado os dois processos, da imigração e da emigração, sobretudo daqueles mais velhos que já não conseguem mais os níveis de produtividade exigidos, em torno de 10 t/dia [...]. Esta situação tem produzido um quadro de itinerância generalizado, aliado à situação de desespero de muitas famílias, posto que não há o seguro desemprego e nem a aplicação do Fundo de Assistência Social, equivalente a 4\% (1\% do açúcar, $1 \%$ da cana e $2 \%$ do álcool), do total do 
faturamento das usinas. Este fundo consta da Lei Federal $\mathrm{N}^{\mathrm{O}}$. 4870, de dezembro de 1965.

No que se refere aos migrantes oriundos de outros estados do Brasil, esse grande fluxo de trabalhadores se dirige anualmente para boa parte da região de Ribeirão Preto, pois as colheitas de café, laranja e, sobretudo, cana-de-açúcar necessitam de uma mão de obra abundante e barata, sem maiores necessidades de qualificação.

Essa migração temporária, que em muitos casos se faz permanente ao longo da vida de muitos trabalhadores volantes, era até vista como positiva pelos donos do capital, inclusive para muitos a razão do "sucesso"” do Proálcool (Programa Nacional do Álcool).

Nos dias de hoje, nos canaviais dominados pela Usina Ibirá e pela Usina Santa Rita, nota-se uma mudança quanto à composição e ao lugar de origem dos trabalhadores migrantes.

No que diz respeito à região de origem desses trabalhadores migrantes, a maioria deles são procedentes do Maranhão, Alagoas e Paraíba, além dos oriundos do nordeste de Minas Gerais. Trata-se de uma mudança que vem ocorrendo em vários municípios produtores de cana-de-açúcar no estado de São Paulo.

Muitos dos migrantes atuais são provenientes do Maranhão, Ceará, Alagoas, Piauí, estados que, no passado, tinham pouca participação neste processo. A explicação que pode ser dada para a mudança da cartografia migratória reside em dois fatos: um deles se reporta ao processo de espoliação das terras dos camponeses das áreas de cerrado, ora ocupadas pela soja. Outro fato se reporta à enorme intensificação do ritmo de trabalho, traduzida em termos da média de cana cortada, em torno de 12 toneladas diárias. Este fato está

7 SZMRECSÁNYI, T. O Planejamento da Agroindústria Canavieira do Brasil (1930-1975). São Paulo: Hucitec/Unicamp, 1979, em alusão a frase proferida pr um ex-presidente da Cooperativa dos Produtores de Açícar e Alcool do Estado de São Paulo (COPERSUCAR). 
diretamente relacionado à capacidade física, portanto, à idade, na medida que, acima de 30 anos de idade, os trabalhadores já encontram mais dificuldades para serem empregados. Desta sorte, a vinda destes outros migrantes cumpre a função de repor, por meio do fornecimento de maior força de trabalho, o consumo exigido pelos capitais cuja modernização e tecnificação são maiores (SILVA, 2005, p 122).

Um marco importante desse processo foi a safra de 1997. Nessa ocasião, a usina Santa Rita, arrendatária da Usina Amália, havia atrasado o pagamento de seus fornecedores de cana (e esses, por sua vez de seus trabalhadores rurais) e também os acertos salariais e rescisões de contrato dos seus trabalhadores, industriais e rurais. Os trabalhadores migrantes, em sua maioria, oriundos da região do médio Jequitinhonha, instalados em pensões e habitações precárias na cidade, partiram, depois do acerto trabalhista, rumo as suas regiões de origem, a medida que iam recebendo os benefícios atrasados.

Grande parte deles não voltou para a próxima safra. A partir de então, tem-se observado uma redução dos trabalhadores migrantes provenientes dessa região do país em relação aos oriundos de outros estados brasileiros, como Maranhão, Paraíba e Alagoas.

No que tange às trabalhadoras canavieiras, estas tiveram seus empregos significativamente reduzidos ao longo da década de 1990, sendo hoje a minoria em várias turmas de trabalhadores rurais.

Elas foram, juntamente com os trabalhadores mais velhos, inclusive àqueles que superam a faixa dos 30 anos, os mais prejudicados por esse processo de reestruturação produtiva que atinge os canaviais, seja por meio da intensificação do processo de mecanização, ou por meio da imposição das “médias de produção" e flexibilização dos direitos trabalhistas, negando às trabalhadoras outras dimensões de sua vida: como o direito de serem mães e o direito de se inserirem nessa outra história, contada a partir do eito dos canaviais, como comenta Silva (2004, p. 69-70): 
No momento atual, esses valores do patriarcado, que imputam à mulher a condição de incapaz para o exercício de atividades pesadas voltam à tona. Protegida por esses valores, as usinas, ao não empregarem as mulheres, além de impingirlhes o estatuto de sobrantes, apagam suas histórias enquanto trabalhadoras rurais e responsáveis em boa parte pelos níveis de acumulação de seus capitais, uma vez que sempre computaram mais de dezoito horas diárias de trabalho, em razão da dupla jornada de trabalho [...]. As mulheres são aquelas que mais foram afetadas, além dos mais velhos. Consideradas frágeis, incapazes de garantirem os níveis de produtividade no corte da cana - em torno de dez toneladas foram relegadas às funções mais desvalorizadas e mais perigosas. A busca de outras alternativas de trabalho alia-se à consciência da situação em que vivem.

Histórias como a de uma ex-trabalhadora rural, abandonada pelo marido, ainda com os filhos pequenos, convertida em chefe de família e numa das “melhores” cortadoras de cana da Usina Amália.

Cuidei dos meus cinco filhos só, graças a Deus, sem a ajuda do pai deles, sem nada, graças a Deus, cortei muita cana [...]. Todo mundo vinha me procurar para ir cortar cana com eles, com os empreiteiros [...] Eles vinham buscar na porta de casa, atrás. A safra vai começar, você vai cortar cana comigo, era assim. Se eu não gostava de trabalhar com um turmeiro, eu já pegava um outro caminhão, ia trabalhar para outro, era assim, agora não (Ex-cortadora de cana. Depoimento colhido em 29 jul. 2005).

Este depoimento revela a condição de "boa cortadora" de cana, conforme Silva (1999, p. 201-16) para o aumento do rendimento familiar, condição conhecida e apropriada pelos empreiteiros, mas que, ao longo dos anos, foi se refletindo, segundo a depoente, em "problemas de coluna, hérnia de disco, bico de papagaio, tudo isso: eu não agüentava mais agachar para cortar cana”. Essa ex-trabalhadora rural trabalhou na Usina Amália até 1991, quando foi aposentada por invalidez aos 40 anos de idade. 
Segundo Rossini (2006, p.18):

A mudança que tem se operado em relação ao trabalho tem sido enorme. Homens e mulheres lutam pela sobrevivência procurando manter o trabalho durante todo o ano, atividade que se torna rara a cada dia devido à mecanização intensa na agricultura. Há permanente perda de ocupação tanto para os homens como para as mulheres. Assiste-se, a cada dia, possibilidade de engajamento na força de trabalho para as pessoas mais especializadas em máquinas sofisticadas colhedeiras, tratores, caminhões e treminhões. Assim sendo, intensificam-se as masculinidades na agricultura moderna: apenas homens operam máquinas.

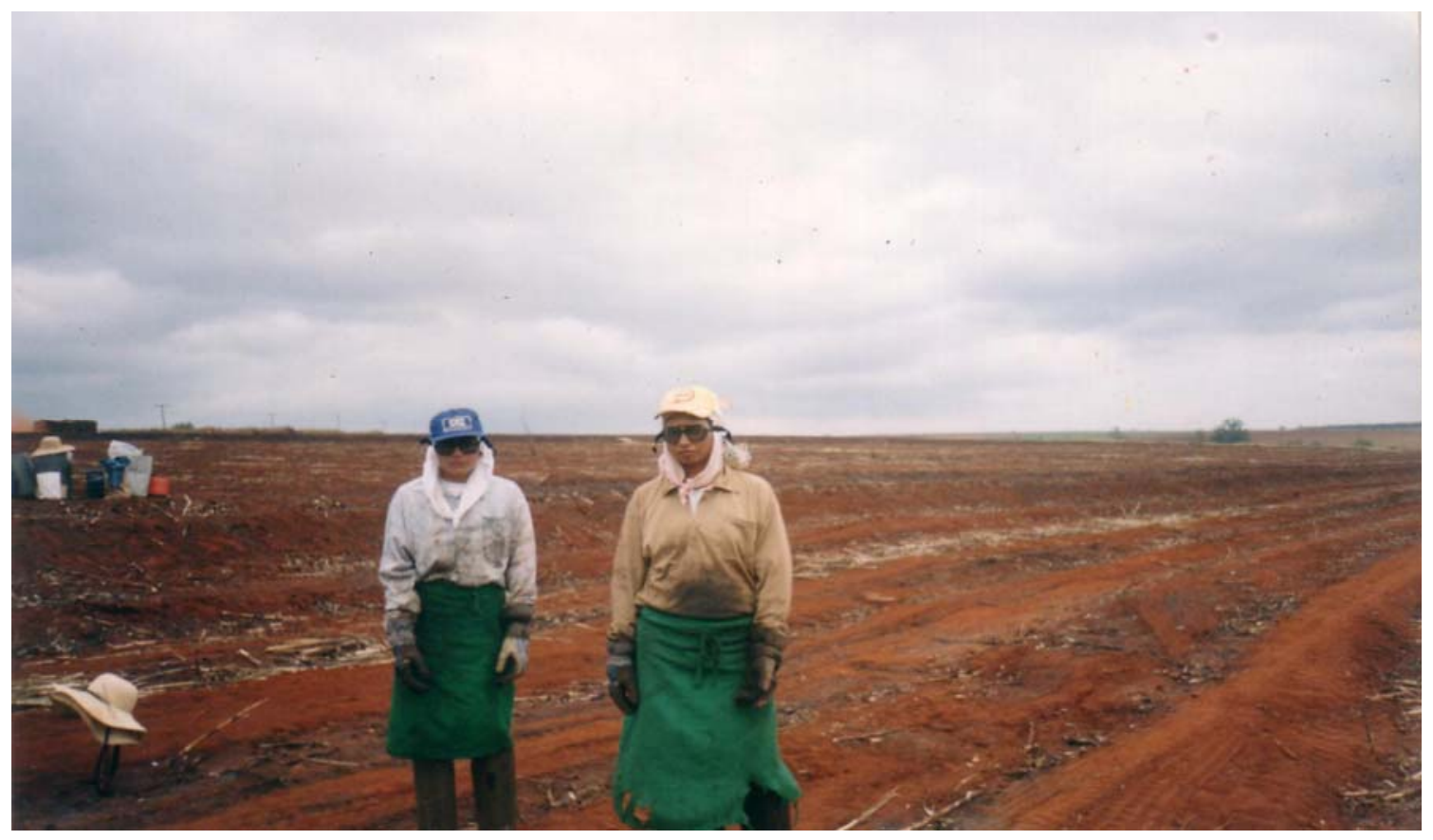

Figura 28 - Bituqueiras. Trabalhadoras rurais de Santa Cruz das Palmeiras/SP. Antiga seção Parazito (hoje, terras da Usina Santa Rita), São Simão, 2004. Fotografia cedida pelo Sindicato dos Trabalhadores Rurais de Santa Rosa de Viterbo. (Pesquisa de campo, 25 jul. 2005).

Muitas vezes, as relações de trabalho são escamoteadas por meio de estratégias buscadas pelo capital para aprimorar seu processo de reprodução ampliada com a reestruturação da produção e do trabalho nos canaviais. 
Em nossa área de estudo, este processo ocorre principalmente por meio de cursos de treinamento oferecidos pelo departamento de recursos humanos da usina, muitas vezes em parceria com órgãos técnicos do Estado na região:

O departamento de recursos humanos da Usina Ibirá está habilitando 12 trabalhadores rurais como aplicadores de herbicida no campo desde a semana passada, com aulas teóricas e práticas ministradas em parceria com o SENARServiço Nacional de Aprendizagem Rural, regional de Cajuru. O RH da Ibirá, explica que a intenção da usina é a de valorizar os funcionários. "A política da nossa empresa é de sempre dar aos trabalhadores de todos os setores a possibilidade de melhorar de vida e conseguir melhor remuneração".

L. C. T., que faz a segunda safra na usina na queima de cana e mora em Santa Rosa diz que está muito contente com a oportunidade. "É um melhora de vida para mim, para mim e para os companheiros".

(Disponível em <http:// www.ojornalzao.com.br $>$ Acesso em 25 abr.2006)

O diretor industrial da Usina Ibirá explica ainda que o maior investimento da usina é na área social, com a valorização do trabalhador com a realização de cursos de aperfeiçoamento e capacitação técnica “. Nesta entressafra fizemos 4 mil horas de cursos.

(Disponível em <http://www.ojornalzao.com.br> Acesso em 25 abr.2006)

Esses cursos de treinamento, oferecidos pelas usinas, visando à qualificação profissional em várias categorias de trabalhadores na lavoura canavieira, não atendem apenas a esse requisito. Eles imputam no trabalhador a lógica dos “tempos modernos” de reprodução capitalista, ancorada na apropriação de elementos próprios do toyotismo no que tange às relações de trabalho como a formação de grupos de trabalho, a polivalência e a rotação de tarefas (RUMIN, 2004, p. 153). No entanto, devemos tomar certo cuidado na análise destes procedimentos, visto que se tratam de mais um artifício tomado pela reorganização do capital para subsunção real dos trabalhos, como salienta Antunes (1999): “o trabalhador torna-se déspota de si próprio”. 
Tal como a lógica desse ideário é concebida [o toyotismo], as resistências, as rebeldias, as recusas são completamente rejeitadas como atitudes contrárias "ao bom desempenho da empresa [...]. Trata-se de um momento efetivo do estranhamento do trabalho [que o autor designou como envolvimento manipulado] ou, se preferirem, da alienação do trabalho, que é, entretanto, levada ao limite, interiorizada na alma do trabalhador", levando-o a só pensar na produtividade, na competitividade, em como melhorar a produção da empresa, da sua "outra família" [...], criando-se um círculo infernal da desefetivação e da desumanização no trabalho: é o trabalhador pensando para o capital. [...] Era preciso deixar que o saber intelectual do trabalho florescesse e fosse também ele apropriado pelo capital. O que Jean Marie Vincent, entre outros, denominou como a fase de vigência do trabalho intelectual abstrato. (ANTUNES, 1999, p. 205-6). [Grifos do autor]

No corte de cana, atividade remunerada de acordo com o nível de produção individual do trabalhador, essa lógica se materializa por meio das “metas” de produção diária exigida por muitas usinas, imposições que, além de promover níveis explosivos de exploração do trabalho e de intensificação do ritmo de trabalho, favorecem a incorporação dessa lógica destrutiva da competição e da elevação da produtividade do trabalho, incentivando a produção de “bons cortadores” de cana. Nas palavras de um entrevistado:

Sete anos [de trabalho], eu não tenho nada de reclamar deles [os Biagi, arrendatários da Usina Ibirá] não, porque eles são uma excelente pessoa, até eles não gostam que nós fala. Quando chega lá, eles fala assim para nos: olha nós plantamos isso, nossa cana. Não é falar: ah que nos fizemos, porque isso. Eles gostam que a gente fala é nosso aquilo ali, se a gente não falar isso eles não gostam. Mas falar que é nosso; mas eu não acho jeito de falar não (...) (Trabalhador da lavoura de cana. Depoimento colhido em 3. abr. 2006).

Segundo a matéria jornalística: 
O Departamento Agrícola da Açucareira Santa Rosa (Santa Rita) a partir desse ano, vai premiar os cortadores de cana que mais se destacaram nos serviços.

A premiação desta safra (94/95) ocorreu no dia 8 passado, no clube da ADCA, num evento onde participaram, a Gerência, a Assistência Social e encarregados e foram premiados 100 empregados.

Depois de agradecer a todos pelas metas atingidas, o Gerente Agrícola, deu início à premiação.

O gerente de Recursos Humanos, explicou que o objetivo da empresa nessas premiações, além de mostrar a gratidão pelo trabalho realizado, é buscar um melhor rendimento do funcionário, diminuindo o número de faltas e dando aos cortadores de cana a oportunidade de trabalharem com maior satisfação.

Os prêmios oferecidos foram: TV, Aparelho 3/1, Cd, Fogão, Batedeira, Liquidificador, Ventilador, Rádio-Relógio, Ferro e outros. (Fonte:AÇUCAREIRA Santa Rosa entrega prêmio aos melhores. O Jornalzão, Santa Rosa de Viterbo, ano 1, $\mathrm{n}^{\circ}$ 4, p.1, 15 dez. de 1994.).

Thomaz Jr. (2002, p.211-12) também aponta a ocorrência de tais incentivos pelas usinas por meio de diversos "prêmios" distribuídos no final da safra aos "bons cortadores de cana", prática que denominou de "Bingo da Morte”, visto que muitos trabalhadores não mediam esforços para conseguir tais "recompensas" no final da colheita, elevando assim o ritmo de produtividade do trabalho nos canaviais e a “média” de produção diária do conjunto de trabalhadores, premiando na próxima safra o emprego de uns e carimbando a demissão de tantos outros trabalhadores do corte manual de cana-de-açúcar. A busca por “essa recompensa” eleva ao extremo o desgaste físico do trabalhador, marcas que se refletem no seu corpo, e que já vão ser sentidas no seu ritmo de trabalho da próxima colheita, além dos danos causados à saúde desses trabalhadores, muitas vezes se manifestando de forma fatal ou em mutilações no corpo que acompanham suas vidas. Nas palavras de um entrevistado 
hora que você vai almoçar, quando é pé-de-rolo, você pega naquele pé-de-rolo assim, você trabalha agachado o dia interinho. Você vai levantar assim, dói tudo. Você não agüenta o dia a dia. Cada ano que passa a tua potência vai caindo mais ainda [...] Cada ano que passa, cada dia que passa, nós comenta lá na roça, cada dia que passa nós vai caindo mais ainda, nós em vez de subindo, vai caindo mais ainda, porque a velhice chega, o cansaço chega, a dor no corpo aumenta mais ainda. Agora eles estão pondo um professor para nós, nós faz alongamento todo dia, alongamento no serviço. Depois que começou a fazer esses alongamento no serviço, acabou um pouco da dor, não dói mais tanto assim, mais só que o sol pesa muito, que nem agora o sol está baixando muito.

A percepção estranhada dessa lógica por parte do trabalhador que não “acha jeito” de falar que aquela cana também é dele, reflete essas estratégias do capital de "um envolvimento interativo [que] aumenta ainda mais o estranhamento do trabalho, amplia as formas modernas da reificação, distanciando ainda mais a subjetividade do exercício de uma cotidianidade autêntica e autodeterminada” (ANTUNES, 1999, p. 222).

Rumin (2004) deteve-se mais particularmente às relações estabelecidas entre processo de reestruturação produtiva na agroindústria canavieira e o agravamento das condições de trabalho, e conseqüentemente das condições de vida e de saúde do trabalhador na agricultura canavieira. Podemos notar elementos dessa relação no último depoimento do trabalhador citado, no esforço para “endireitar o corpo", do posicionamento corporal durante o trabalho, principalmente da postura ergonômica no corte da cana. Os riscos ocupacionais, associados à fraca alimentação dos trabalhadores e diante das exigências do aumento da produtividade, vêm fazendo com que várias usinas da região de Ribeirão Preto, recomendadas por especialistas e nutricionistas, adotem um complemento alimentar a base de glicose e práticas de exercício físicos logo na chegada ao eito (SILVA,2004, p.47-8). Os trabalhadores canavieiros da Usina Ibirá recebem esse complemento alimentar, o mesmo não ocorre com os que trabalham na Usina Santa Rita. 
Nos entra, nós pega às 7 horas. Nos já pica cartão, já pega o complemento alimentar que ele fala, aí depois faz a ginástica, tudo [exercícios de alongamento seguindo as instruções de um professor de educação física] [...], logo aí já entra pro serviço [...] e aí vai direto até 9 horas e pouco. Depois das nove horas, tem trinta minutos de almoço, depois nos levanta, continua a rotina de novo, aí nós vai até uma hora, até uma e pouco. Depois da uma hora nós toma o café, tem mais trinta minutos, depois nós levanta e continua outra vez a rotina e nos vai até dez para as quatro . Dez para as quatro nos pica o cartão, guarda as ferramenta, monta dentro do ônibus e vem até chegar aqui [...] As ferramenta deixa tudo, ao menos nessa parte a Usina Ibirá, nessa parte, eles não deixam nem você trazer folhão da roça para a casa não, é tudo lá no serviço. É tudo lá, é tudo, tudo lá. Eles não deixam, porque eles têm medo, né que uma hora a pessoa né... Tem muita desavença né, esse negócio de problema assim, então eles não deixam.

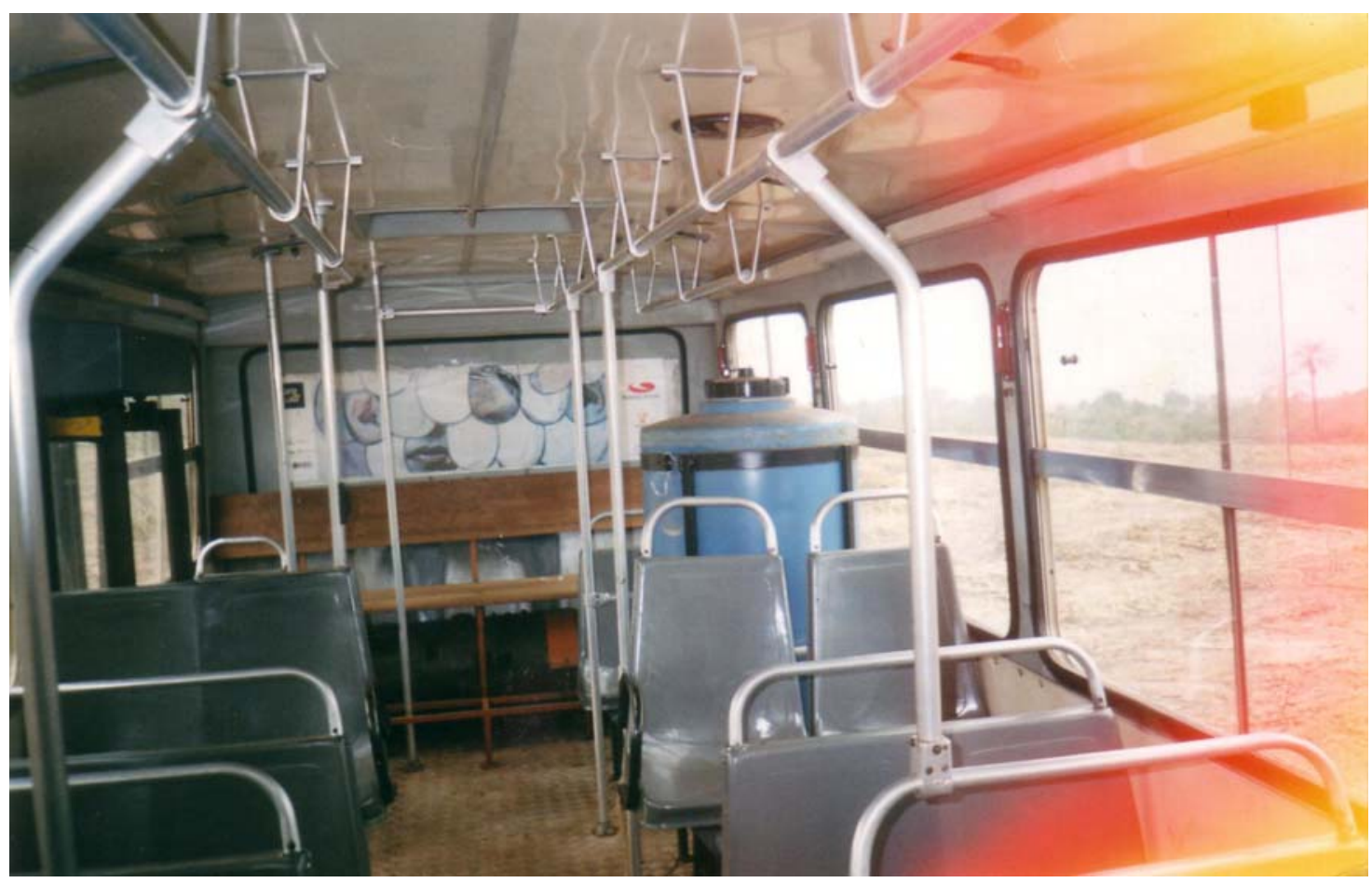

Figura 29 - Espaço para a água gelada, de deixar os bonés e guardar as ferramentas no ônibus rural. Foto cedida pelo Sindicato dos Trabalhadores Rurais de Santa Rosa de Viterbo. (Pesquisa de campo, 25 jul. 2005).

Podemos constatar a percepção destes sujeitos sociais enquanto força de trabalho, dispêndio físico de músculos e energia para sustentar as 
engrenagens de acumulação, próprias desse momento da aceleração contemporânea:

No sentido específico, desfigurado, o trabalho, ao invés de caminho para a ação, reduz-se ao labor [...] Ou seja, para os trabalhadores do corte da cana, o eito despe seu universo de representações e revela sua dimensão eminentemente orgânica, que sobrevive às exigências físicas do dia de trabalho (SILVA, 2006, p.17).

Ainda conclui Antunes (1999, p.182-83) ao discutir os fundamentos básicos de um novo sistema de metabolismo social:

[...] sob o sistema de metabolismo social do capital, o trabalho que estrutura o capital desestrutura o ser social. O trabalho assalariado que dá sentido ao capital gera uma subjetividade inautêntica no próprio ato de trabalho. Numa forma de sociabilidade superior, o trabalho, ao reestruturar o ser social, terá desestruturado o capital. E esse mesmo trabalho autodeterminado que tornou sem sentido o capital gerará as condições sociais para o florescimento de uma subjetividade autêntica e emancipada, dando um novo sentido ao trabalho pois, de acordo com o autor o sentido dado ao ato laborativo pelo capital é completamente diverso do sentido que a humanidade pode conferir a ele.

Buscamos compreender as implicações sociais do processo de reestruturação da produção e do trabalho nos canaviais para a vida desses sujeitos sociais, vida que não se encontra separada do trabalho, embora cada vez mais condenada a uma existência subalterna, a uma cidadania negada, em que o trabalho é percebido como algo separado, estranho, sem sentido. 


\subsection{A configuração fundiária da Fazenda Amália: herança do grupo Matarazzo e o processo de reestruturação produtiva do capital sucroalcooleiro}

Em 23 de dezembro de 1990, oito empresas do grupo Matarazzo, situadas na capital paulista e no município de Santa Rosa de Viterbo entraram com pedido de concordata preventiva, e entre elas estava a Agro Industrial Amália S.A ${ }^{8}$. Poucos meses antes, em outubro de 1990, as S.A. Indústrias Reunidas Fábricas Matarazzo haviam vendido as ações que lhe cabiam da joint venture Fermenta Produtos Químicos Amália $^{9}$ à sua parceira no empreendimento, representada pela empresa Miles do Brasil (subsidiária da Miles Inc. dos Estados Unidos, que por sua vez pertencia ao grupo alemão do setor químico Bayer). O ácido cítrico é um produto orgânico obtido no processo de fermentação do açúcar, daí a instalação da indústria de acidulantes nas cercanias da Usina Amália

Mais à frente, em fevereiro de 1994, a Indústria Matarazzo de Embalagens (IMESA S.A.) foi vendida à Cia. Artivinco de Papel e Celulose, sediada na cidade de Itatiba/SP, hoje respondendo pela razão social Rio Pardo Papel e Celulose.

Desfazia-se, dessa forma, a estratégia industrial do grupo Matarazzo, típica das primeiras fases do processo de industrialização brasileira no século XX, de maximização do aproveitamento da matéria-prima e dos subprodutos

\footnotetext{
8 AMÁLIA pede concordata. O Santa Rosa, Santa Rosa de Viterbo, ano 1, no 23, p. 1, 24 dez. 1990.

9 A indústria Fermenta Produtos Químicos Amália foi criada em 1976 para a produção de ácido cítrico. Após a transferência das ações que pertenciam a S.A. Indústrias Reunidas F. Matarazzo à Bayer, esta última tornou-se proprietária exclusiva da planta industrial da empresa. Junto com as ações do grupo Matarazzo, o grupo alemão também adquiriu 10 hectares de terra para fins de futura ampliação das instalações produtivas da indústria (Cf. O SANTA ROSA, Santa Rosa de Viterbo, ano 1, $\mathrm{n}^{0}$. 18, p.1, 15 set.1990). Em 2001, o grupo Bayer vendeu a empresa à transnacional inglesa Tate\& Lile, uma das líderes mundiais na produção de ácido cítrico.
} 
gerados no processo produtivo, e que na Fazenda Amália era representada pelas unidades industriais anexas à Usina Amália acima mencionadas.

A integração vertical da S.A I.R.F.M., verificada na atividade sucroalcooleira na Fazenda Amália, fazia-se acompanhar da grande importância dessas empresas no emprego de trabalhadores oriundos de municípios vizinhos, principalmente dos que residiam na cidade de Santa Rosa de Viterbo.

Com o anúncio da concordata da Agro Industrial Amália S.A., o passo seguinte foram as demissões sucessivas de trabalhadores, que já ocorriam, mas que foram relativamente expressivas a partir de 1991, como nos revela a tabela 10.

Tabela 10

Trabalhadores de algumas empresas e setores das I.R.F. M. na Fazenda Amália.

\begin{tabular}{|l|l|l|l|}
\hline & 30 nov.1990 & 1 jan. 1991 & 3 jul.1991 \\
\hline Agro & 1.462 & 1.194 & 1.216 \\
\hline Papel & 244 & 240 & 199 \\
\hline IMODSA & 229 & 227 & 217 \\
\hline Canavieiros & 455 & 439 & 439 \\
\hline Bóias Frias & 1.278 & 790 & 790 \\
\hline Total & 3.668 & 2.890 & 3.133 \\
\hline
\end{tabular}

Fonte: O Santa Rosa, Santa Rosa de Viterbo, p. 3, 10 ago.1991.

O grupo Irmãos Cury S.A. foi a primeira empresa a lidar com a produção sucroalcooleira da antiga usina desde a perda do controle da mesma pelas Indústrias Reunidas F. Matarazzo S. A. no início da década de 1990.

O início de suas atividades, na produção de açúcar e álcool, na antiga usina, se deu em 1993, por meio de um contrato de arrendamento firmado com 
a CEIET Agro Mercantil Ltda; da planta industrial e de parte de suas terras na Fazenda Amália, até o ano de $2001^{10}$.

A isto se acrescentam as aquisições feitas pelo grupo Cury de parte das terras controladas pela Copersucar na antiga fazenda dos Matarazzo (por se constituir numa das credoras da empresa dos Matarazzo e que recebeu parte das terras do devedor, como mencionado anteriormente). Como a Copersucar não estava interessada diretamente na produção canavieira, mas sim na comercialização de seus principais produtos, vendeu a maior parte das suas terras na Fazenda Amália para o principal grupo econômico interessado em ampliar seus domínios canavieiros nas cercanias da antiga usina: o grupo Cury $^{11}$.

Tabela 11

Fazenda Amália

Propriedades fundiárias adquiridas pelo grupo Irmãos Cury S.A em maio de 1992

\begin{tabular}{|l|c|}
\hline \multicolumn{1}{|c|}{ Município } & $\begin{array}{c}\text { Área aproximada (em } \\
\text { ha) }\end{array}$ \\
\hline Santa Rosa de Viterbo & $4.024,5$ \\
\hline São Simão & $1.775,7$ \\
\hline Total das terras adquiridas & $5.800,2$ \\
\hline
\end{tabular}

Fonte: Certidões de matrículas fornecidas pelo Cartório de Registro de Imóveis de Cajuru. Coleta de informações em 7 ago.2006, 17 nov. 2006 e 3 jan. 2007.

${ }^{10}$ Cf. O Jornalzão, Santa Rosa de Viterbo, ano 4 , nº. 137, p. 3, 19 jan. 1998.

${ }^{11}$ Trata-se de doze matrículas de imóveis: cinco certidões de imóveis fornecidas pelo Cartório de Registro de Imóveis de Cajuru, perfazendo uma área aproximada de 1.138 hectares e sete certidões de matrículas de imóveis obtidas no Cartório de Registro de Imóveis de São Simão, contendo aproximadamente 800 hectares, colhidas entre agosto de 2006 e janeiro de 2007. Segundo os mesmos registros, a dação das terras da Agro Industrial Amália à Copersucar se deu em 3 de setembro de 1993 e a venda delas para a Diné Agroindustrial Ltda se efetivou em 19 de novembro de 1996, datas que se referem as escrituras de compra e venda de todos esses imóveis. 
Tabela 12

Fazenda Amália

Terras adquiridas pelo grupo Cury em novembro de 1996 da COPERSUCAR

\begin{tabular}{|l|c|}
\hline \multicolumn{1}{|c|}{ Município } & $\begin{array}{c}\text { Área aproximada (em } \\
\text { ha) }\end{array}$ \\
\hline Cajuru & $1.137,7$ \\
\hline Santa Cruz da Esperança & 249,3 \\
\hline São Simão & 800,3 \\
\hline Total das terras adquiridas & $2.187,3$ \\
\hline
\end{tabular}

Fonte: Certidões de matrículas fornecidas pelo Cartório de Registro de Imóveis de Cajuru. Coleta de informações em 7 ago.2006, 17 nov. 2006 e 3 jan. 2007.

Por meio da análise de quase todas as certidões de matrículas de imóveis rurais fornecidas pelos cartórios de registro de imóveis das cinco comarcas que possuíam terras da Fazenda Amália (Cajuru: municípios de Cajuru e Santa Cruz da Esperança, Cravinhos: município de Serra Azul, Santa Rosa de Viterbo, São Simão e Tambaú), foi possível constatar que a transmissão da maior parte das terras da Fazenda Amália se deu para importantes usinas de açúcar e álcool da região de Ribeirão Preto, sendo que, dentre elas, a mais beneficiada, foi, sem dúvida, o grupo Cury, que não só arrematou parte importante das terras de Amália, como também conseguiu o arrendamento, até 2001, da planta industrial, moendo na usina cana proveniente de terras próprias adquiridas da antiga Fazenda Amália.

Desta forma, o processo de territorialização do capital sucroalcooleiro manteve intacta a lógica de produção da matéria-prima, sustentada na grande propriedade, e controlada pelos grupos usineiros. Terra muitas vezes garantidora de empréstimos obtidos junto a instituições financeiras, lógica que remonta a aprovação da Lei de Terras em 1850, como revela Martins (1979).

Lógica esta que também garante o poder dos grandes empresários e proprietários de terras desse país ao se apropriarem de toda a sorte de recursos financeiros e créditos (muitas vezes se tratando de instituições públicas), sem nenhum compromisso com o desenvolvimento social do local, a não ser de 
seus próprios interesses, nutrir e avolumar o padrão de reprodução ampliada do capital, alheio ao local e à maior parte de seus moradores.

Esses acontecimentos nos possibilitam afirmar que grande parte da matéria-prima consumida no processo produtivo, na antiga Usina Amália, era procedente de terras arrendadas do grupo Cury junto a CEIET Agro Mercantil Ltda e também de terras próprias do grupo Cury na antiga Fazenda Amália, compradas da Copersucar.

O processo de territorialização da agroindústria se efetivava por meio da produção, em terras próprias, da cana esmagada na indústria, ou seja, por meio de um processo de territorialização do monopólio, conforme aponta Thomaz Júnior (1988), principal forma de produção e controle da gramínea no abastecimento das moendas industriais na década de 1980 e meados da seguinte.

O controle via arrendamento de instalações industriais inteiras, assim como de inúmeras propriedades arrendadas vai acelerar, na década seguinte, na região de Ribeirão Preto. Esse processo foi capitaneado, sobretudo, pela elevação do preço da terra na região, objeto de disputa de poderosas agroindústrias, assim como o estabelecimento de contratos de arrendamento (mais próximo a contratos de parceria entre arrendados e usinas), direcionando parte importante dos capitais anteriormente aplicados na incorporação de terras para o setor produtivo: investimentos em tecnologia, aquisição ou mesmo montagem de outra unidade agroindustrial.

Além disso, por possuir uma unidade de moagem relativamente próxima à usina de Santa Rosa de Viterbo, a Usina Santa Rita fazia aproveitava melhor os canaviais, maximizando a capacidade produtiva na parte industrial. Isso também significou uma re-organização do trabalho, cujos arranjos incidirão fortemente no número, composição e origem dessa força de trabalho, sobretudo na indústria e nos talhões da gramínea, como explanaremos mais a frente. 
As alterações na configuração fundiária da Fazenda Amália, de propriedade de um dos maiores grupos econômicos deste país até então; associadas às mudanças na esfera produtiva, ligadas à reestruturação setorial sucroalcooleira e às novas ofensivas do capital no ramo nos fornecem uma leitura diferente do processo de territorialização da agroindústria canavieira na antiga Fazenda Amália, no estado de São Paulo e no Brasil.

A fragmentação da Fazenda Amália, em dezenas de glebas menores, manteve o controle territorial das mesmas, de parte de grandes empresas, a maioria delas sediadas na metrópole de São Paulo, não diluindo a grande propriedade, mas o proprietário, "invisível” na imensidão dos canaviais.

Diminuiram também os postos de trabalho no interior da agroindústria: queda sentida no processo produtivo na fabricação do açúcar e nas destilarias de álcool com a crescente automação na produção; decréscimo percebido na lavoura com a expansão da mecanização em diversas fases do processo produtivo da cana: do preparo do solo ao plantio, adubação, tratos culturais e mais sensivelmente na colheita. Trata-se de processos diferenciados dentro da mesma lógica de territorialização, uma reestruturação do padrão de acumulação do capital diferente das anteriores, mas implacável quanto à sua essência, uma lógica destrutiva do humano como já apontado por Antunes (1999).

Os negócios da família Cury, na produção sucroalcooleira, na antiga Fazenda Amália, giravam em torno do empresário e fazendeiro Nelson Afif Cury, que emprestou seu nome à empresa que controlava as atividades econômicas da família: Diné Agroindustrial Ltda. A personificação do usineiro em Nelson Afif Cury e da Usina Santa Rita, como empresa arrendatária da antiga usina é muito diferente da simbologia e do mito criado em torno do Conde Francisco Matarazzo Jr. e das Indústrias Reunidas Francisco Matarazzo S. A.

A família Matarazzo possuía, desde a década de 1920, sua mansão nas cercanias da colônia-sede da Fazenda Amália, restrito a um universo muito 
limitado de pessoas e funcionários do palacete da família. Um mundo que nutre muitas histórias entre os trabalhadores da antiga fazenda.

No que se reporta ao grupo Cury, o usineiro é invisível para a maior parte dos trabalhadores, não tendo casa na fazenda e muito menos sendo o seu proprietário. Mesmo oriundo de Ribeirão Preto, a sua relação com os trabalhadores da antiga usina se dá por meio de uma série de instituições e sujeitos sociais "estranhos” à lógica anterior: muitas atividades do campo e da indústria foram terceirizadas, parte dessas empresas prestadoras de serviços são de outros municípios, a Fazenda Amália dividida já não é mais aquela das S. A I.R.F.M.

No final da safra 1997-1998, o grupo Irmãos Cury dava sinais de que não iria concluir o contrato de arrendamento, acertado junto à Vitercana Agro Industrial e Mercantil S.A. até o ano de 2001. Até mesmo envolviam a futura safra da gramínea e a produção de açúcar e álcool na antiga usina Amália, com o atraso no pagamento da cana recebida de fornecedores e arrendadores, além dos trabalhadores da indústria e da parte agrícola da própria usina em novembro de 1997.

Esses acontecimentos repercutiam em outras esferas, como, por exemplo, no adiamento do pagamento de salários a trabalhadores volantes contratados pelos fornecedores da gramínea, no funcionamento do comércio local, sobretudo na cidade de Santa Rosa de Viterbo, e a ameaça presente do desemprego para os empregados na indústria e realização da próxima safra ou ocupação na entressafra nas lides agrícolas.

O acerto prolongado dos salários de outubro, novembro e dezembro de 1997, além do pagamento de $13^{0}$ salário, férias e aviso prévio, sobretudo entre os trabalhadores da indústria e da administração, causou também o acionamento da justiça do trabalho por parte do Sindicato dos Trabalhadores das Indústrias de Alimentação de Santa Rosa de Viterbo. Este entrou com uma ação coletiva, reunindo trabalhadores da empresa, solicitando a penhora de 
64.938 sacas de açúcar cristal para pagamento das verbas rescisórias dos funcionários demitidos.

Os desdobramentos desta posição resultaram no pagamento no ano de 2000, da maior parte dos ex-trabalhadores da Usina Diné que entraram com requerimento trabalhista na justiça. Os desarranjos causados pelo atraso nos pagamentos de fornecedores, arrendadores e trabalhadores da parte administrativa, industrial e agrícola da própria empresa sinalizavam para a não realização da próxima safra canavieira por parte do grupo Cury.

As ameaças advindas dessa possibilidade movimentaram o poder público municipal, sobretudo o prefeito e a Câmara Municipal de Santa Rosa de Viterbo a buscar uma resposta para essas incertezas. Elas ocorreram principalmente por meio de reuniões com representantes do grupo Cury, que se estenderam durante boa parte da entressafra, sem sucesso nas negociações com o grupo usineiro que se manteve irredutível quanto à possibilidade de realizar a próxima safra.

As dívidas contraídas pelo grupo Cury, junto ao Banco Bradesco S.A, resultaram na dação em pagamento de parte das terras adquiridas na Fazenda Amália. Poucos meses depois disso, as terras foram vendidas à Companhia Energética Santa Elisa, parceira da instituição financeira na produção sucroalcooleira em Sertãozinho.

Aí entra em cena, nas discussões sobre o futuro da produção canavieira na antiga Fazenda Amália, a figura de Maurílio Biagi Filho, presidente de várias empresas da família Biagi, dentre elas, a Central Energética Santa Elisa, agora também proprietária de parcelas importantes de terra da Fazenda Amália.

Maurílio Biagi Filho, na época, presidente de uma das maiores corporações agroindustriais deste país, sobretudo no setor canavieiro, foi o principal articulador dos acordos que resultaram no arrendamento da antiga usina para o grupo Irmãos Biagi, braço do grupo familiar, dirigido pelo primo Pedro Biagi Netto. 
Esses acertos levaram a retomada das atividades canavieiras na antiga usina, prejudicada desde a entressafra em virtude dos desdobramentos relativos à moagem industrial na safra 1998/1999.

A reestruturação produtiva no setor sucroalcooleiro acentuava a fusão e a incorporação de unidades processadoras, dinamizando o padrão de acumulação do capital; a aquisição de tecnologia e treinamento dos funcionários, desenvolvimento aparente, ambientalmente e capitalisticamente correto, de acordo com os novos tempos: de expansão dos preços e perspectivas de mercado para seus principais subprodutos no mercado externo e interno, nutridos pela lógica criada em torno do agronegócio. Entrava em cena o grupo Biagi e a antiga Usina Amália passava a ser denominada Usina Ibirá. É o que trataremos no próximo item

\subsection{Usina Ibirá: a organização territorial do capital e do trabalho no velho "mar de cana"}

O anúncio oficial do arrendamento da usina pelo grupo Irmãos Biagi S.A. se deu em 09 de abril de $1998^{12}$, por Maurílio Biagi Filho (proprietário de várias indústrias na região de Ribeirão Preto) em favor da Usina da Pedra, dirigida pelo seu primo Pedro Biagi Netto ${ }^{13}$, para um período de 15 anos $^{14}$ ( até 2013).

${ }^{12}$ Cf. O Jornalzão, Santa Rosa de Viterbo, ano 4, nº. 143, p. 1, 11 abr.1998

${ }^{18}$ Pedro Biaggi Netto é primo de Maurílio Biagi Filho e filho de Baudílio Biagi. Este último, em associação com o irmão Gaudêncio Biagi, assumiu posteriormente o controle da Usina da Pedra, fundada pelo pai Pedro Biagi, em 1931, no município de Serrana (BIAGI: 1987. p. 70 e 89). Conforme revela Ramos (1983, p. 98), o grupo Irmãos Biagi deveria ser desmembrado em dois: o da família de Baudílio e o da família de Maurílio Biagi, pois "a separação de bens e propriedades entre os Irmãos Biagi parece ter sido uma”estratégia” do patriarca Pedro Biagi, que queria evitar litígios e desavenças entre eles depois que morresse” (RAMOS, 1983, p. 98 apud Revista Senhor, 8 set. 1982, p. 50). Cabe à família do primeiro, o controle da usina supracitada, além de outros setores como o de equipamentos odontológicos, por meio 
O grupo Irmãos Biagi S.A. - Açúcar e Álcool é composto por várias unidades agroindustriais na região de Ribeirão Preto, como a Usina Da Pedra, sediada no município de Serrana, e a Usina Buriti, localizada em Buritizal, além da Usina Ibirá, em Santa Rosa de Viterbo.

Recentemente, o grupo, seguindo a lógica de expansão da agroindústria canavieira para o noroeste do estado (mais especificamente para as regiões de Andradina, Araçatuba e Presidente Prudente), está construindo a Usina Ipê, no município de Nova Independência, região de Andradina. Tal empreendimento encontra-se em processo de licenciamento ambiental ${ }^{15}$.

Desta forma, a Usina Ibirá insere-se num dos maiores grupos usineiros do nordeste paulista. De origem familiar, a atuação da família Biagi nos

da empresa Dabi-Atlante, sediada em Ribeirão Preto. Já o grupo constituído pela família de Maurílio Biagi tem a maior parte de seus negócios relacionados à agroindústria canavieira como a Companhia Energética Santa Elisa e a Zanini S.A. Equipamentos Pesados, situadas no município de Sertãozinho, além da Refrescos Ipiranga Indústria e Comércio que pertence à Cia. de Bebidas Ipiranga, fabricante do refrigerante Coca-Cola em Ribeirão Preto (SP). Recentemente, o filho de Maurílio Biagi, Maurílio Biagi Filho, ex-presidente da Central Energética Santa Elisa, é sócio da Usina Moema e da Crystalsev. Também foi membro da diretoria executiva da Sociedade Rural Brasileira e integrante do Conselho de Desenvolvimento Econômico e Social da Presidência da República e conselheiro da Única (Disponível em: www.srb.org.br e www.terra.com.br/istoedinheiroe /442/economia/era_alcool.htm Acesso em 25 jan. 2007). Gaudêncio Biagi, o mais velho dos filhos de Pedro Biagi, aparece como acionista minoritário da Usina da Pedra e da Usina Santa Elisa. Para maiores informações sobre a família Biagi e suas atividades econômicas, ler: BIAGI, Luiz Lacerda. A Família Biagi: Os Primeiros Cem Anos (1888-1988). Ribeirão Preto: Laserprint Editorial, 1987 além de consultas a homepages das principais empresas acima mencionadas.

${ }^{14}$ Pesquisa de campo na sede da Usina Ibirá, 23 set.1996.

${ }^{15}$ Embora o início das instalações industriais esteja prevista para setembro de 2006, a empresa realizou o plantio mecanizado em 2.319, 91 ha.. dos 4.083, 15 ha. ( ou seja, $66,6 \%$ da área total) que serão colhidos mecanicamente, na forma queimada ou crua, conforme legislação ambiental. (O Observador, Serrana - ano 35, no . 416, 11 set. 2006, p. 5). 
negócios canavieiros reporta à década de 1920, por meio da sociedade que originou a Usina Barbacena, no município de Pontal, em $1922^{16}$.

A mini-safra de 1998, iniciada em julho, garantia a retomada das operações agroindustriais em Amália, com organização social do trabalho distinta se tomada em comparação as safras anteriores: os investimentos na parte industrial com a implantação de novos equipamentos e treinamento de pessoal, o crescimento das taxas de mecanização da lavoura e da qualidade da matéria-prima reduziram os postos de trabalho e ampliaram a produção no conjunto da agroindústria canavieira, como revela a Tabela 13

${ }^{16} \mathrm{O}$ início das atividades de Pedro Biagi no ramo canavieiro é concomitante à participação de Francesco Matarazzo na Sociedade Agrícola Fazenda Amália, em 1920 (juntamente com o fazendeiro e usineiro Francisco Schmidt e o industrial Alexandre Siciliano) após a morte de Henrique dos Santos Dumont.

A década de 1930 principia com a construção da primeira usina totalmente de Pedro Biagi: a Usina da Pedra, em 1931; e a administração completa das Indústrias Reunidas Francisco Matarazzo sobre a fazenda Amália, desde 1931 sob o comando de Francisco Matarazzo Júnior.

Fazemos alusão a importantes grupos usineiros deste país, com atuação em diferentes setores da economia, mas que viviam momentos distintos em suas empresas: o primeiro se tratava do maior e mais importante grupo econômico do país até meados da década de 1960; o outro, os primeiros passos mais largos de um dos maiores grupos econômicos ligados à agroindústria, sobretudo, à agroindústria canavieira deste país nos dias de hoje: a família Biagi.

Apesar de ter suas empresas subdividas desde a década de 1950, entre os irmãos Biagi, não podemos negar a adesão dos interesses da família como a posição de Maurílio Biagi Filho, ao encaminhar as negociações sobre o arrendamento da antiga usina para o controle da Usina da Pedra, a partir de então dirigida pelo primo Pedro Biagi Filho e ao mesmo tempo, tornando-se num dos principais adquirentes de terras que pertenciam à Fazenda Amália. 
Tabela 13

Usina Ibirá - Santa Rosa de Viterbo /SP

Produção sucroalcooleira (Safras1998 /99- 2006/07)

\begin{tabular}{|c|c|c|c|c|c|c|c|}
\hline Safra & $\begin{array}{l}\text { Moagem de } \\
\text { cana }{ }^{1}\end{array}$ & $\begin{array}{l}\text { Açúcar } \\
\text { Branco }^{2}\end{array}$ & $\begin{array}{l}\text { Açúcar } \\
\text { Demerara } \\
\text { VVHP }^{4}\end{array}$ & Total $^{2}$ & $\begin{array}{l}\text { Álcool } \\
\text { Hidratado }^{3}\end{array}$ & $\begin{array}{l}\text { Álcool } \\
\text { Anidro }\end{array}$ & Total $^{3}$ \\
\hline $1998 / 99$ & 735.815 .330 & 408.355 & 652.788 & 1.061 .143 & 30.566 .000 & --- & 30.566 .000 \\
\hline $1999 / 00$ & 645.511 .650 & 913.193 & --- & 913.193 & 26.221 .750 & --- & 26.221 .750 \\
\hline $2000 / 01$ & 470.509 .440 & 607.329 & --- & 607.329 & 19.314 .000 & --- & 19.314 .000 \\
\hline $2001 / 02$ & 899.164 .420 & 1.348 .300 & --- & 1.348 .300 & 37.342 .000 & --- & 37.342 .000 \\
\hline $2002 / 03$ & 1.046 .869 .980 & 1.761 .050 & --- & 1.761 .050 & 45.571 .000 & --- & 45.571 .000 \\
\hline $2003 / 04$ & 1.149 .100 .390 & 1.791 .783 & --- & 1.791 .783 & 50.783 .000 & --- & 50.783 .000 \\
\hline $2004 / 05$ & 1.157 .471 .760 & 1.555 .210 & --- & 1.555 .210 & 50.457 .000 & --- & 50.457 .000 \\
\hline $2005 / 06$ & 1.134 .163 .310 & 1.408 .381 & --- & 1.408 .381 & 53.669 .000 & --- & 53.669 .000 \\
\hline $2006 / 07$ & 1.166 .314 .000 & 1.845 .400 & --- & 1.845 .400 & 54.369 .000 & --- & 54.369 .000 \\
\hline
\end{tabular}

Fonte: Pesquisa de campo na sede da Usina Ibirá, 25/07/2006.

Notas:

${ }^{1}$ Em Kg.

${ }^{2}$ Sacas de $50 \mathrm{Kg}$.

${ }^{3}$ Em litros.

${ }^{4}$ Açúcar demerara VVHP: trata-se de uma especificação técnica para designar um tipo de açúcar bruto, mais escuro, utilizado para reprocessamento industrial e não diretamente para o consumo humano. A sigla vem do inglês, very very hight pol, conforme a explicação do engenheiro químico da Usina Ibirá. Esse tipo de açúcar foi responsável pela maior parte da produção de açúcar no ano de 1998, devido à escassez do tempo para a obtenção de um açúcar de melhor qualidade. (Pesquisa de campo na sede da Usina Ibirá, 23 set. 2006).

Por meio de uma conversa com um técnico da parte agrícola ${ }^{17}$ da Usina Ibirá, toda a produção de cana-de-açúcar da usina é obtida por meio de terras arrendadas. Seguindo os passos do mesmo, inferimos que estas terras são arrendadas da Canamor Agroindustrial e Mercantil S.A, proprietária da usina e de parte considerável das terras que compunham a Fazenda Amália, além de arrendamentos de terras de outros proprietários, cujas terras situam-se, na maioria das vezes, na proximidade dos canaviais destinados ao consumo produtivo na Usina Ibirá.

${ }^{17}$ Pesquisa de campo no escritório da Usina Ibirá, em 14 ago. 2006. 
No tocante ao arrendamento das terras da Canamor Agro Industrial e Mercantil S.A., esta perfaz uma área de 8.132,54 ha. dos 16.364 ha. de cana plantada pela Usina Ibirá, ou seja, 49,2\% \% da área total. Os fornecedores de cana respondem pelo cultivo em 5.642 ha. da gramínea consumida no processo produtivo (ou seja, 34,1\% da matéria-prima total), perfazendo uma produção de 468.334 toneladas (ou seja, aproximadamente 36\% do total da cana moída, prevista para a safra 2006/2007, ou seja, 1.300 .000 toneladas) de cana-de-açúcar esmagadas.

O restante da produção, processado na usina (838.000 toneladas), é oriundo de canaviais arrendados, sejam os da Canamor Agroindustrial e Mercantil S.A. ou de outros proprietários, sendo que estes constituem, na maioria das vezes, mais um contrato de parceria com a usina do que um arrendamento de terras. Ainda no que tange à produção nos canaviais controlados pela Usina Ibirá, 91 mil toneladas da cana não foram processadas pelas moendas da Usina Ibirá, em Santa Rosa de Viterbo. Cerca de 75 mil toneladas da gramínea foram esmagadas pela Usina da Pedra, em Serrana (a mais importante a maior unidade agroindustrial do grupo Irmãos Biagi S. A.) devido às limitações da capacidade de moagem da Usina Ibirá (que se encontra em torno de 1.200.000 toneladas de cana), e 16 mil toneladas foram processadas pela Usina Santo Alexandre, localizada em Mococa, em função da maior proximidade desta dos canaviais que forneciam a matéria-prima à Usina Ibirá, inviabilizando os custos de transporte.

Quanto à colheita da cana-de-açúcar, a mecanização nas terras arrendadas da Canamor Agro Industrial e Mercantil S. A. é maior em relação aos canaviais de fornecedores, arrendadores ou parceiros. As diferentes taxas de mecanização da colheita $(78 \%$ em terras arrendadas controladas diretamente pela Usina Ibirá, percentual que recua para 57\% , levando-se em conta a área total colhida) apontam para o diferencial técnico existente entre os canaviais de fornecedores e os que são na maior parte do processo produtivo controlado pela própria usina. 
Desde o início das atividades da Usina Ibirá, diversas melhorias foram feitas nas instalações industriais e na parte agrícola, procurando elevar a produtividade agroindustrial. As necessidades da planta industrial foram reparadas por meio da instalação de uma nova caldeira com capacidade para 150 toneladas/hora (a caldeira antiga tinha capacidade de 120 toneladas/hora e fora levada pela Diné ${ }^{18}$ ) e da construção de dois silos com capacidade para 7 mil sacas cada um ${ }^{19}$. Já na parte agrícola, os investimentos foram focados na melhoria da qualidade da cana-de-açúcar, prejudicada pelos desdobramentos que cercearam o funcionamento da antiga usina no final da safra 1997/1998 e na entressafra de 1998, como a baixa qualidade e produção da cana, condição contornável, segundo o gerente administrativo da época, “dentro de mais ou menos três anos ${ }^{20}$,

Estes apontamentos permitem entender a pequena moagem da gramínea na Usina Ibirá, nas safras 1998/1999, 1999/2000 e 2000/2001, cuja expansão encontrava-se comprometida por arranjos que precisavam ser feitos na unidade agroindustrial para viabilizar a elevação da produção de açúcar e álcool.

A curta duração das safras iniciais da Usina Ibirá: com matériaprima de baixa qualidade e pouco produtiva e instalações industriais carecendo de ajustes, muitos deles estruturais, foram a solução encontrada para continuarem a moagem da cana e a produção de açúcar e álcool, sobretudo na safra de 2000/2001, a mais curta de todas, durando um pouco mais que três meses.

\footnotetext{
${ }^{18}$ Cf. depoimento do gerente industrial da Usina Ibirá do período. Ainda segundo o mesmo "A caldeira gera vapor que ajuda a alimentar as máquinas da usina. Outra parte é alimentada eletricamente" (SAFRA da Ibirá começa dia 24. O Jornalzão, Santa Rosa de Viterbo, ano 5, nº. 177 p. 5, 8 mai.1999).

${ }^{19}$ Cf. IBIRÁ busca qualidade total na safra 2001. O Jornalzão, Santa Rosa de Viterbo ano 7, $\mathrm{n}^{\circ}$ 279, p. 1, 19 mai. 2001.

${ }^{20}$ Cf. O Jornalzão, Santa Rosa de Viterbo ano 4, nº 141, p, 1, 14 mar.1998.
} 
Tabela 14

Usina Ibirá - Santa Rosa de Viterbo/SP.

Duração e período da safra canavieira (1998/99 - 2006/07)

\begin{tabular}{|c|c|c|c|}
\hline Safra & $\begin{array}{c}\text { Duração } \\
\text { (em dias) }\end{array}$ & Início & Término \\
\hline $1998 / 1999$ & 145 & $01 / 07 / 1998$ & $22 / 11 / 1998$ \\
\hline $1999 / 2000$ & 155 & $24 / 05 / 1999$ & $25 / 09 / 1999$ \\
\hline $2000 / 2001$ & 95 & $05 / 07 / 2000$ & $07 / 10 / 2000$ \\
\hline $2001 / 2002$ & 150 & $29 / 05 / 2001$ & $25 / 11 / 2001$ \\
\hline $2002 / 2003$ & 172 & $14 / 05 / 2002$ & $01 / 11 / 2002$ \\
\hline $2003 / 2004$ & 181 & $08 / 05 / 2003$ & $04 / 11 / 2003$ \\
\hline $2004 / 2005$ & 221 & $10 / 05 / 2004$ & $16 / 12 / 2004$ \\
\hline $2005 / 2006$ & 208 & $09 / 05 / 2005$ & $02 / 12 / 2005$ \\
\hline $2006 / 2007$ & 194 & $09 / 05 / 2006$ & $18 / 11 / 2006$ \\
\hline
\end{tabular}

Fonte: Pesquisa de campo no escritório da Usina Ibirá, 23 set. 2006.

Com as modificações executadas na parte agrícola e industrial da Usina Ibirá, já podemos notar o crescimento do esmagamento da cana e da produção de açúcar e álcool a partir da safra 2001/2002. Na safra 2006/2007, a trituração da matéria-prima nas moendas e a produção de açúcar e álcool hidratado, girou em torno de 1.300.000 de toneladas de cana, 1.845.400 sacos de $50 \mathrm{Kg}$ de açúcar e 59.000.000 litros de álcool hidratado, ou seja, uma ampliação de 43,4\% na moagem de cana, 42,5\% na fabricação de açúcar e 48,2\% na produção de álcool hidratado, tomada em comparação com a safra 1998/1999, a primeira do grupo Irmãos Biagi S.A., na antiga Usina Amália.

Os resultados mais significativos na produção agroindustrial vieram mesmo na safra 2001/2002. Comparando-se a produção de cana, açúcar e álcool hidratado deste período com os números da safra anterior, o crescimento é de 91,1\%, 122\% e 93,34\%, respectivamente.

Salto semelhante observa-se no número de trabalhadores nas partes administrativa, industrial e agrícola da usina, como revela a Tabela15: 
Tabela 15

Usina Ibirá - Santa Rosa de Viterbo/SP

Número de trabalhadores. (Safras 1998/1999 - 2006/2007)

\begin{tabular}{|l|c|c|c|}
\hline Safra & Administração $^{1}$ & Indústria $^{2}$ & Agrícola $^{3}$ \\
\hline $1998 / 1999$ & 15 & 167 & 31 \\
\hline $1999 / 2000$ & 16 & 147 & 519 \\
\hline $2000 / 2001$ & 22 & 150 & 406 \\
\hline $2001 / 2002$ & 26 & 156 & 375 \\
\hline $2002 / 2003$ & 22 & 163 & 346 \\
\hline $2003 / 2004$ & 33 & 161 & 459 \\
\hline $2004 / 2005$ & 40 & 191 & 435 \\
\hline $2005 / 2006$ & 43 & 197 & 656 \\
\hline $2006 / 2007$ & 42 & 190 & 690 \\
\hline
\end{tabular}

Obs:

${ }^{1}$ Abrange os trabalhadores do faturamento, limpeza, segurança e escritório, na sede da usina. Muitos serviços administrativos são realizados na Usina da Pedra, em Serrana.

2 Envolve os trabalhadores da destilaria, da fabricação do açúcar e serviços relacionados com o processo industrial sucroalcooleiro, como os trabalhadores do pátio da usina e os guincheiros que capturam a cana caída no chão no descarregamento dos caminhões

${ }^{3}$ Inclui trabalhadores da área rural como motoristas de caminhão e as turmas de corte de cana.

Fonte: Pesquisa de campo no escritório da Usina Ibirá. Santa Rosa de Viterbo, 25 jul. 2006 e 31 ago. 2006.

No tocante ao primeiro caso, esse aumento relativo envolve funcionários que exercem diferentes funções como serviços de faturamento, limpeza, segurança e escritório. Além disso, muitos serviços administrativos são realizados na Usina da Pedra, em Serrana, ocupando outros profissionais.

No que se refere aos trabalhadores da parte industrial esse aumento é mais pronunciado entre as safras de 2003/2004 e 2004/2005, na qual o número de funcionários passou de 161 para 191 trabalhadores. Essa ampliação no pessoal ocupado nas atividades industriais da Usina Ibirá é 
explicado segundo a gerência da usina pela redução dos prestadores de serviços que atuavam na área industrial ${ }^{21}$ da empresa..

Na última safra, houve novo decréscimo na quantidade de trabalhadores da parte industrial, sinal dos processos de automação e inovações tecnológicas sucessivas que vêm sendo incorporadas aos processos produtivos do açúcar e do álcool nas usinas. Na Usina Ibirá, essa tendência não é diferente, como mostra as figuras 30 e 31, com destaque para as máquinas e poucos operários. Não podemos deixar de registrar que parte dos profissionais da parte industrial são compostos por técnicos empregados no laboratório da empresa.

A Usina Ibirá não produz álcool anidro. Ela gera em sua destilaria o álcool hidratado, principalmente o do tipo H1, conforme as especificações técnicas e de controle de qualidade da Copersucar.

Por meio da conversa com um engenheiro químico da usina, a produção de álcool hidratado obedece às diretrizes de produção do etanol em todas as processadoras de açúcar e álcool do grupo Irmãos Biagi S.A. Ancorando-se na divulgação dos dados da última safra (2006-2007) pela Unica (União da Agroindústria Canavieira Paulista), a Usina Ibirá respondeu pelo esmagamento de 1.166.314 toneladas de cana-de-açúcar, ou seja, 16,65\% da cana moída pelo grupo Irmãos Biagi S.A.; 87.945 toneladas de açúcar, ou seja, 28,73\% da produção total de açúcar do grupo usineiro; 25\% da produção de álcool hidratado $\left(54.630 \mathrm{~m}^{3}\right.$ ) e $12,75 \%$ da produção total do etanol grupo Irmãos Biagi S.A.

${ }^{21}$ Cf. Conversa com o engenheiro químico, no escritório da Usina Ibirá, em 23 set.2006. 


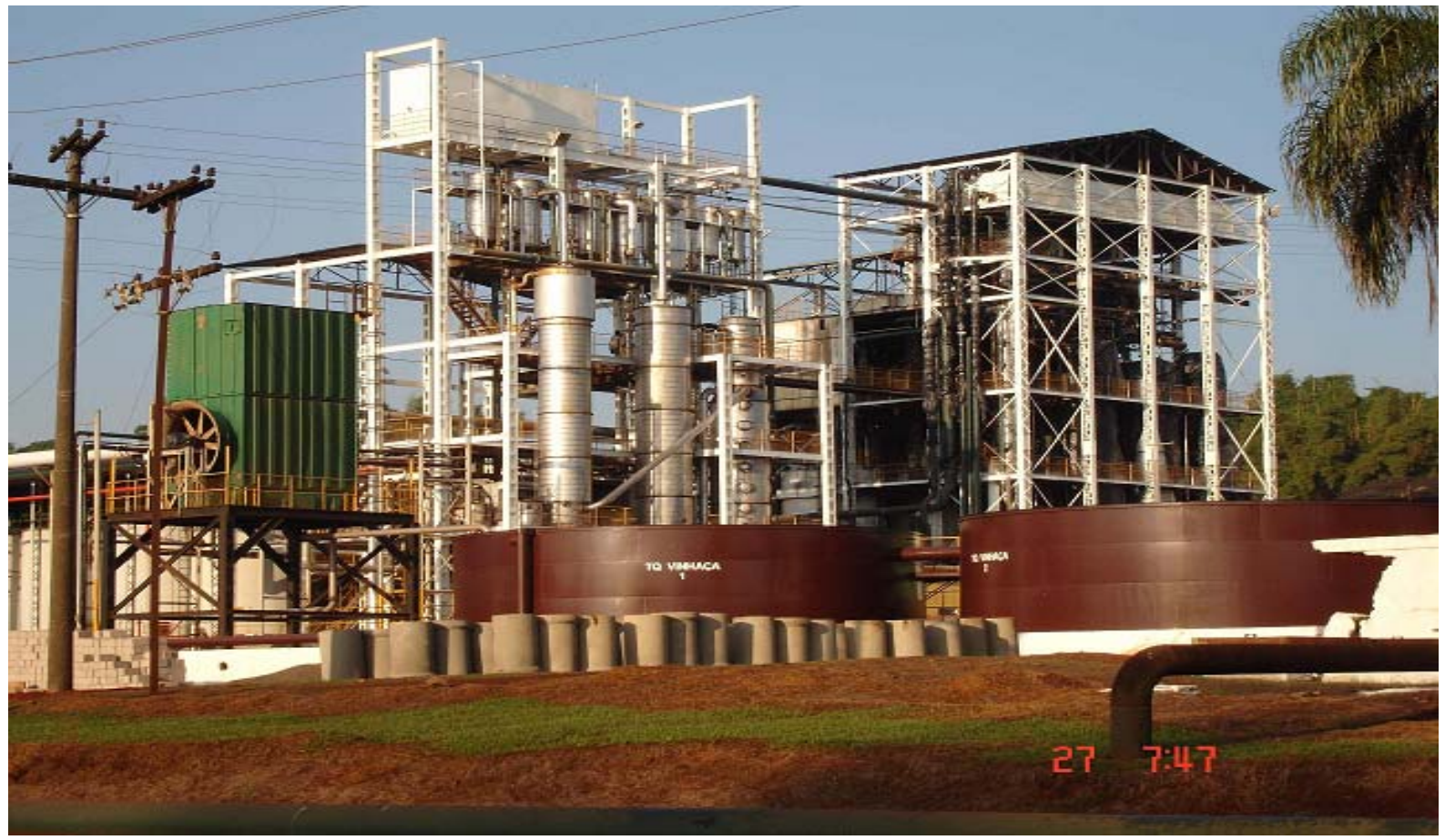

Figura 30 - Usina Ibirá, herdeira de Amália na produção de açúcar e álcool.

Foto cedida pela Usina Ibirá. (Pesquisa de campo em setembro de 2006)

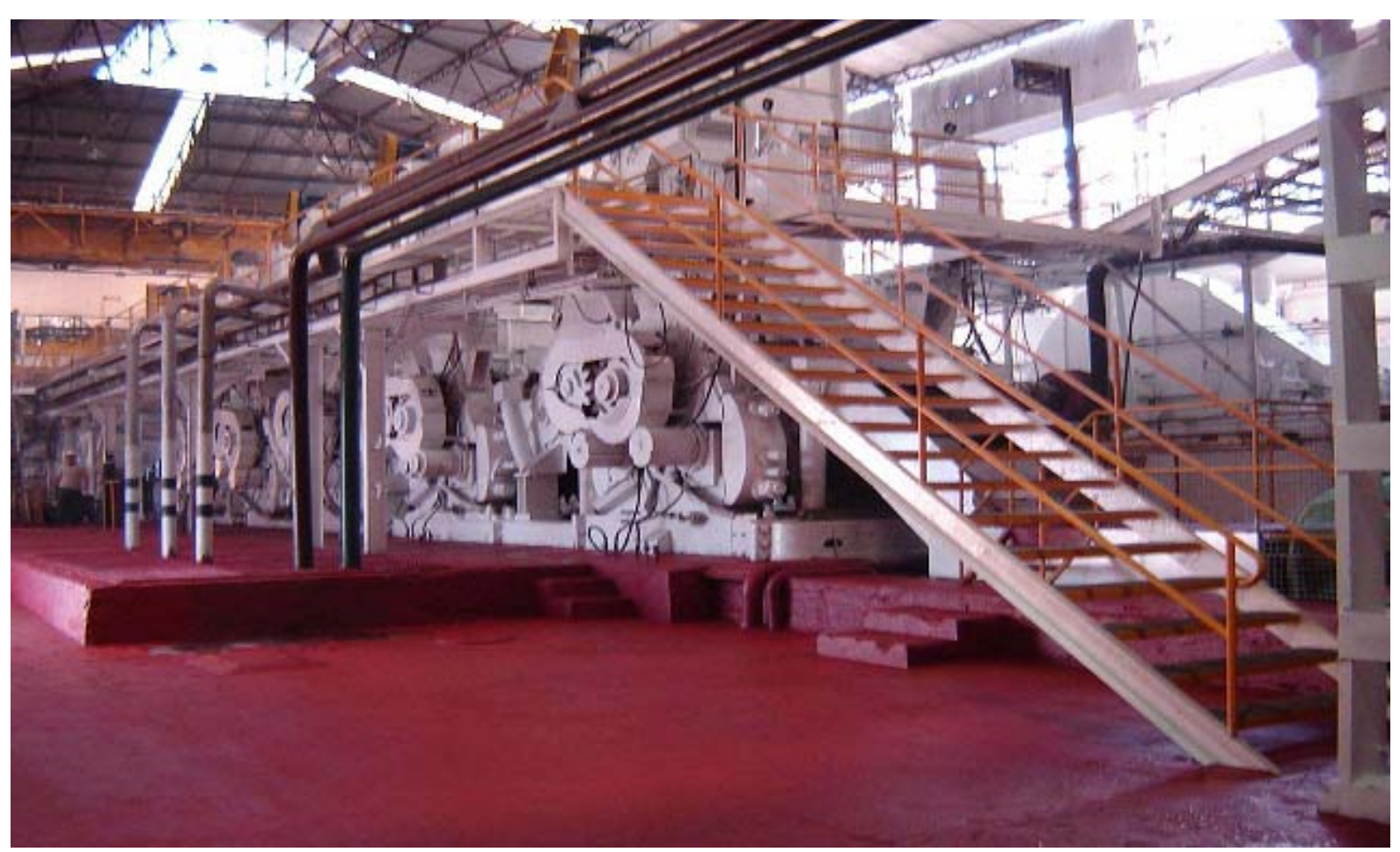

Figura 31 - Dentro da usina, muitas máquinas, poucos operários

Foto cedida pela Usina Ibirá. (Pesquisa de campo em setembro de 2006) 
O grupo Irmãos Biagi S.A destaca-se por ser um dos maiores grupos usineiros paulistas, com destaque para a grande produção alcooleira, em particular a da Usina da Pedra, a sexta maior produtora de etanol da região Centro-sul canavieira. Apesar de responder por uma pequena parte da produção sucroalcooleira do grupo empresarial, a produção da Usina Ibirá é importante, sobretudo pela disponibilidade e fertilidade de terras contínuas voltadas para a cultura de cana-de-açúcar (terras ora arrendadas de parte da antiga Fazenda Amália (hoje, pertencentes a Canamor Agroindustrial e Mercantil S. A), de pequenos e médios proprietários e fornecedores locais), em localização privilegiada na região de Ribeirão Preto, a maior produtora de cana-de-açúcar, açúcar e álcool e de "mutilados e mortos entre os trabalhadores canavieiros” do mundo. 
Considerações Finais 


\section{Considerações finais}

A territorialização da agroindústria canavieira, inscrita na antiga Fazenda Amália, no início da década de 1990, está relacionada com processos de endividamento crescentes que acompanharam as Indústrias Reunidas F. Matarazzo e que assumiram proporções significativas desde meados da década de 1970, dívidas estas garantidas por meio de hipotecas de parcelas consideráveis da grande propriedade com fins de modernização e reprodução do capital no complexo sucroalcooleiro como também para avalizar empréstimos realizados por outras empresas do grupo Matarazzo no país, como sinalizam as certidões de imóveis analisadas.

Não podemos compreender unicamente o processo de territorialização da agroindústria canavieira na Fazenda Amália, no período em que esta era propriedade única e exclusiva da família e das empresas Matarazzo sem levar em conta o empresário e as demais empresas do grupo familiar, pelo fato de o proprietário não ser tratado e referido unicamente como usineiro e latifundiário, apesar de o ser, mas como industrial herdeiro do maior grupo empresarial da América Latina até a década de 1960.

A representação do industrial "Conde Matarazzo Jr" sobrepunha à de usineiro, grande produtor de cana e latifundiário. E as demais empresas do grupo Matarazzo, sobretudo às situadas na capital paulista, possuíam maior importância e participação nas receitas do grupo do que o complexo produtivo instalado na Fazenda Amália, diferente do ocorrido com muitas famílias de usineiros que conformaram grandes grupos econômicos, principalmente a partir da década de 1960 no estado de São Paulo, entre os quais o grupo Biagi, um dos maiores plantadores de cana e produtores de açúcar e álcool do país, que atualmente planta e produz na antiga usina e fazenda Amália.

A maximização do aproveitamento da matéria-prima agrícola não se dava unicamente por meio do controle e produção própria de cana-de-açúcar, 
tomate e frutas para beneficiamento industrial nesta fazenda, mas também da produção e do controle próprio de outras matérias primas vegetais, como atesta Vichnewski (2004) em relação ao algodão no interior paulista entre as décadas de 1930 e 1960, além do controle da comercialização e sujeição de outros proprietários que forneciam os insumos a serem consumidos em suas várias indústrias.

A fase áurea para a empresa e o empresário Matarazzo Jr. se confundem com um período próprio do processo de industrialização brasileira: o controle e o aproveitamento das matérias-primas industriais e a integração vertical da produção, imortalizada no logotipo das Industrias Reunidas F. Matarazzo - das grandes chaminés e fumaças incessantes fundamentadas na insígnia: Fides, Honor, Labor.

Da mesma forma, na memória social e coletiva daqueles que passaram, conheceram ou trabalharam na Fazenda Amália, a sua história é em geral associada à história do grupo Matarazzo e de seu sucessor: o Conde Francisco Matarazzo Júnior, histórias nutridas pelo próprio mito Matarazzo, como aponta Martins (1976,1981), Silva (2001) e vários depoimentos coletados nesta pesquisa.

A concordata da Usina Amália também significou a derrocada do grupo Matarazzo na produção econômica brasileira, em suas múltiplas ramificações sejam elas industriais, comerciais e financeiras, expressivas ou não.

Com os novos proprietários da usina, das demais empresas e terras que compunham a Fazenda Amália dos Matarazzo, a figura do (s) proprietário(s) ficou diluída e até mesmo “ïnvisível” visto que os proprietários destas indústrias e terras, inclusive da usina, não se fazem presentes no lugar, visto se tratarem de empresários cujas empresas são oriundas de outras cidades e cuja lógica de atuação perpassa várias escalas espaciais.

A representação sobre o proprietário da Fazenda Amália não é nutrida nem no plano simbólico e imaginário como o fazia Matarazzo Júnior apoiado nas representações vivificadas de seu pai o Conde Matarazzo. Nem é 
sustentada no plano material, uma vez que esses proprietários nem possuem uma segunda residência e ostentação de poder como ainda o faz a família Matarazzo com a manutenção de seu “palacete” em seus domínios vitalícios sobre o município de Santa Rosa de Viterbo.

Temos, portanto, um novo conteúdo das relações sociais no interior das atividades econômicas que hoje constituem a Fazenda Amália. À perda dos referenciais materiais e imateriais, sobretudo dos "órfãos" e "mutilados" de Amália, segue uma recriação no plano do imaginário que permite revificar e territorializar as marcas que ainda se expressam neste míope "mar de cana”: a diversidade da experiência humana em meio à fatigante e à homogeneizante paisagem opressiva dos canaviais.

Por outro lado, a territorialização da agroindústria canavieira na antiga Fazenda Amália não está dissociada do contexto do setor sucroalcooleiro no país como fora destacado nos capítulos anteriores. Muito menos foge da marca que vem acompanhando o setor: a concentração fundiária. A fragmentação fundiária da Fazenda Amália não esconde o controle e o poder territorial de um grupo seleto de empresas que varrem o campo com a "cultura dominante" e ainda impõem a lógica do "mar de cana” a um número sem fim de outros pequenos e médios proprietários, fornecedores ou que estabelecem contratos com as usinas impulsionados pelos rendimentos crescentes e quase sem concorrência e outras atividades produtivas representadas pela plantação da cana-de-açúcar. Horizonte esse que se expande por novas terras, sustentadas por imagens positivas e fabulosas reproduzidas pela grande imprensa desse país.

A agricultura capitalista brasileira, indicativa de um Brasil moderno e produtivo se camuflam nos conceitos e mitos reproduzidos pelo agronegócio (OLIVEIRA, 2004), como as feiras "Agrishow" que movimentam milhões de dólares anualmente na cidade de Ribeirão Preto, mas que não conseguem esconder a morte silenciosa que ocorre nessa região do "mar de cana e do rio de álcool”, como revelam os estudos recentes de Silva $(2004,2005,2006)$ 
sobre as condições de vida e trabalho dos cortadores da gramínea nos canaviais paulistas.

O terceiro ponto importante a ser destacado é que o proprietário da indústria e de parte considerável das terras que pertenciam de modo contíguo à Fazenda Amália se abstém da produção e da moagem da gramínea e do processo produtivo de açúcar e álcool arrendando as terras e a usina, esta última pelo sistema de comodato, por um determinado prazo, detendo-se à captura dos ganhos decorrentes da renda da terra capitalista e o lucro industrial resultante da moagem da matéria-prima canavieira.

Trata-se de uma particularidade nova em nossa área de estudo, num momento oportuno de reprodução do capital sucroalcooleiro, num contexto diferenciado da situação precedente, em que o domínio territorial da produção agrícola e da integração verticalizada da produção agroindustrial eram o principal elemento de territorialização da atividade canavieira na antiga Fazenda Amália, como indicava Thomaz Jr. (1988).

Afastar-se do processo produtivo não significa distanciar-se da dinâmica e do controle do mesmo, uma vez que o que garante e propicia a exploração capitalista do território é o controle da propriedade fundiária, como destacava Ramos (1999).

Além disso, os contratos de arrendamento da usina e das terras controladas pela Canamor Agro Industrial e Mercantil S.A. sinalizam as articulações de interesses tecidas entre as partes, na garantia da exploração territorial capitalista capitaneada e monopolizada por ambas.

Essa rede de interesses avança sobre pequenos e médios fornecedores de cana, que atraídos pelos rendimentos auferidos pela plantação da gramínea, reproduzem, no território, a dinâmica de monopolização do grande capital agroindustrial, protegido por uma série de escudos que escamoteiam muitas vezes o diferencial econômico, político e social entre os vários sujeitos sociais e modalidades de exploração capitalista do território. 
O que no plano das aparências é a produção sucroalcooleira ora levada a cabo pela Usina Santa Rita, nos dias de hoje conduzidas pelo grupo Irmãos Biagi S.A., provocando a falsa impressão de diversidade na plantação da matéria-prima, seja por meio do fornecimento de cana pelos próprios plantadores e proprietários da terra, seja por meio de contratos de arrendamento com "sitiantes" que apenas fornecem suas terras para a produção de cana, conforme o padrão de qualidade engendrado pela usina, auferindo a renda pela produção dos canaviais da usina em suas próprias terras.

Torna-se muito mais complexo discernir a "terra de usina", diferente do que ocorria com a Fazenda Amália do grupo Matarazzo, do início da década de 1930 até 1990.

A disputa por terras torna muitas vezes não recomendável a aquisição de terras, em virtude do preço elevado das mesmas garantido pela competição desenfreada entre as grandes usinas, sobretudo na região de Ribeirão Preto.

Os fornecedores e arrendadores são flertados por propostas ompensadoras para a produção da gramínea, muitas vezes estabelecendo acordos com unidades processadoras relativamente mais distantes que, no entanto, oferecem melhores possibilidades de ganho, como nos revela um médio fornecedor de cana, residente em Santa Rosa de Viterbo, mas que fornece cana-de-açucar para uma outra usina, mais distante que a vizinha Usina Ibirá.

A reflexão revela que a reprodução do capital sucroalcooleiro requer ajustes que se manifestam no território com o fito de dissimular as relações diferenciais de produção e incutir uma lógica que torna obscura suas relações de dominação, como o controle fundiário de parcelas importantes de terra que compunham a Fazenda Amália dos Matarazzo, porém no interior do mesmo processo que promove a reprodução de um padrão de acumulação do capital sucroalcooleiro. 


\section{Referências}

\section{Bibliográficas}

ALVES, Francisco José da Costa. Modernização da Agroindústria e Sindicalismo: Lutas dos Trabalhadores Assalariados Rurais da Região Canavieira de Ribeirão Preto/SP. Tese (Doutorado em Economia) Campinas: Instituto de Economia /Unicamp Campinas.1991.

ALVES, Giovanni. O novo (e precário) mundo do trabalho. Reestruturação produtiva e crise do sindicalismo. São Paulo: Boitempo Editorial, 2000.

ANDRADE, Manuel Correia de. Modernização e Pobreza. A expansão da agroindústria canavieira e seu impacto ecológico e social. São Paulo: Unesp,1994. . A Questão do Território no Brasil. 2 2a Ed São

Paulo: Hucitec, 2004.

. A Terra e o homem no Nordeste. Contribuição ao estudo da questão agrária no Nordeste. $7^{\mathrm{a}}$. Ed. revista e aumentada. São Paulo: Cortez Editora, 2005.

ANTUNES, Ricardo. Os Sentidos do Trabalho: Ensaios sobre a afirmação e a negação do trabalho. São Paulo: Boitempo,2000.

ANTUNES, Romeu José. Histórias de Santa Rosa de Viterbo. Santa Rosa de Viterbo: Ed. O Santa Rosa, 2000.

. Pedras Fundamentais de Santa Rosa de Viterbo. Santa

Rosa de Viterbo: Ed. O Jornalzão, 2006.

BACCARIN, José Giacomo. A Constituição da Nova Regulamentação

Sucroalcooleira. Cadernos do CEAM. Ano V - No. 122, setembro de 2005. UnB, Editora Unesp.

BACELLAR, Carlos de Almeida Prado. \& BRIOSCHI, Lucila Reis (Orgs.) $\mathrm{Na}$ Estrada do Anhanguera: uma visão regional da história paulista. São Paulo: Humanitas FFLCH/USP,1999.

BIAGI, Luiz Lacerda. A Família Biagi: Os Primeiros Cem Anos (1888-1988). Ribeirão Preto: Laserprint Editorial, 1987

BRAY, Silvio Carlos. A Questão da Formação do Capital na Agroindústria Açucareira Paulista nos Fins do Século XIX e Início do Século XX: O Caso da Usina 
London. In: Conferências e Comunicações do $7^{\circ}$ Encontro Nacional de Geografia Agrária. Volume 2

Belo Horizonte: Departamento de Geografia / IGC/ UFMG, 1986. P. 42 - 45. - A Formação do Capital na Agroindústria Açucareira de São

Paulo: Revisão dos Paradigmas Tradicionais. Tese (Livre-docência em Geografia). Rio Claro: Instituto de Geociências e Ciências Exatas/ UNESP, 1989.

CARLI, Gileno de. Gênese e Evolução da Indústria Açucareira de São Paulo. Rio de Janeiro: Irmãos Pongetti,1943.

COUTO, Ronaldo Costa. Matarazzo: a travessia. V. 1 São Paulo: Planeta, 2004. Matarazzo colosso brasileiro. V. 2 São Paulo: Planeta, 2004.

ELIAS, Denise. Globalização e Agricultura. A região de Ribeirão Preto - SP. São Paulo, Edusp, 2003.

HAESBAERT, Rogério. O Mito da Desterritorialização. Rio de Janeiro: Bertrand Brasil, 2004.

HARVEY, David. Espaços de Esperança. São Paulo: Loyola, 2004.

IANNI, Octavio. Origens agrárias do Estado brasileiro. São Paulo: Editora Brasiliense, 1984.

LENCIONI, Sandra. Agricultura e Urbanização. A capitalização no campo e a transformação da cidade. Jardinópolis, o estudo de um lugar. Dissertação (Mestrado em Geografia Humana) São Paulo: FFLCH/USP, 1985.

MARTINS, José de Souza. Conde Matarazzo: o Empresário e a Empresa. $2^{\mathrm{a}}$ ed. São Paulo: Hucitec, 1976.

O Cativeiro da Terra. 2a ${ }^{\text {a }}$ Ed. São Paulo: LECH, 1981

A Militarização da Questão Agrária no Brasil

Petrópolis: Vozes,1984

Não há terra para plantar neste verão. 2a. Ed.

Petrópolis: Vozes,1988.

MENEZES, Marilda Aparecida de. Redes e Enredos nas Trilhas dos Migrantes.

Rio de Janeiro: Relume Dumará, 2002.

OLIVEIRA, Ana Maria Soares de. A Relação Capital - Trabalho na Agroindústria Sucroalcooleira Paulista e a Intensificação do Corte Mecanizado: Gestão do 
Trabalho e Certificação Ambiental. Dissertação (Mestrado em Geografia).

Presidente Prudente: Faculdade de Ciências e Tecnologia/Unesp,2003.

OLIVEIRA, Ariovaldo Umbelino de Agricultura Brasileira: Transformações Recentes. In: ROSS, Jurandyr Luciano Sanches (Org.) Geografia do Brasil. São Paulo: Edusp,1996. P.467-534

A Geografia das Lutas no Campo. 8 $8^{\mathrm{a}}$. Ed São

Paulo: Contexto,1997.

A Geografia Agrária e as transformações territoriais recentes no campo brasileiro. In: CARLOS, Ana Fani Alessandri (org.) Novos Caminhos da geografia. São Paulo: Contexto, 1999. P. 63 - 110.

PASIN, Rodrigo Maimone \& NEVES, Marcos Fava. Fusões, Aquisições $e$ Internacionalização da Agroindústria Sucro-Alcooleira. Ribeirão Preto: FEARP/USP, 2002.

RAFFESTIN, Claude. Por Uma Geografia do Poder. Trad. M. C. França São Paulo: Editora Ática,1993.

RAMOS, Pedro. Um Estudo da Evolução e da Estrutura da Agroindústria Canavieira do Estado de São Paulo. Dissertação (Mestrado em Administração) São Paulo: EAESP/FGV,1983.

Agroindústria Canavieira e Propriedade Fundiária no Brasil. São Paulo: Hucitec, 1999.

ROSSINI, Rosa Ester. Geografia e Gênero: A Mulher na Lavoura Canavieira Paulista. São Paulo. Tese (Livre-docência em Geografia Humana). São Paulo: Faculdade de Filosofia, Letras e Ciências Humanas/USP,1988.

- Mulheres e Homens na força de trabalho na agricultura. O exemplo da macro-área de Ribeirão Preto, 1977-2006. In: XV Encontro Nacional de Estudos Populacionais, ABEP- 2006 (mimeo)

RUMIN, Cassiano Ricardo. Trabalho rural e saúde: um estudo sobre as condições de trabalho e sua relação com a saúde dos cortadores de cana-de-açúcar do município de Pacaembu (SP). .Dissertação (Mestrado em Medicina Social). Ribeirão Preto: Faculdade de Medicina de Ribeirão Preto/ USP, 2004. 
SILVA, André Eduardo Ribeiro da. A Territorialização da Agroindústria Canavieira: a antiga Usina Amália em Santa Rosa de Viterbo/SP. Trabalho de Graduação Individual em Geografia. São Paulo: FFLCH/USP, 2004.

SILVA, Maria Aparecida de Moraes. Errantes do Fim do Século. São Paulo: Editora Unesp,1999.

De Colona a Bóia-Fria In: PRIORE, Mary del (org.) História das Mulheres no Brasil. São Paulo: Editora Unesp, Editora Contexto, 1999. P. 554-560

- Casa Grande e Senzala dos Matarazzo na

Califórnia Paulista. In: Pesquisa Fapesp No 61. São Paulo: Janeiro/Fevereiro de 2001. P. 62-70.

A Cultura na Esteira do Tempo In: São

Paulo em Perspectiva vol.15, Nº 3 São Paulo: Julho/Setembro de 2001. PP.102112.

- Reestruturação produtiva e os impactos sobre os migrantes. In: GIARRACA, Norma (org.) ¿Una Nueva Ruralidad em America Latina? v.1 Buenos Aires: CLACSO, 2001. P. 289-305

.SILVA, Maria Aparecida de Moraes. A luta pela terra: experiência e memória. São Paulo: Editora Unesp, 2004.

- Se eu pudesse, eu quebraria todas as máquinas. In: ANTUNES, Ricardo; SILVA, Maria Aparecida de Moraes (Orgs.) $O$ Avesso de Trabalho. São Paulo: Expressão Popular, 2004. P. 29-77.

- Em busca do passado para conhecer o presente.Trabalhadores migrantes na região de Ribeirão Preto. In: SYDOW, Evanize \& MENDONÇA, Maria Luisa. Direitos Humanos no Brasil 2005. Relatório da Rede Social de Justiça e Direitos Humanos. São Paulo: Rede Social de Justiça e Direitos Humanos,2005b. P. 121 - 125.

(mimeo).

A morte ronda os canaviais. 2006, $25 \mathrm{p}$ - Greve na fazenda. In: Maria Aparecida de Moraes Silva; Delma Pessanha Neves; Ariovaldo Umbelino de Oliveira. (Org.). 
Processo de constituição e reprodução do campesinato no Brasil. 1 ed. prelo: prelo, 2006, v. 1, p. prelo-prelo.

A face oculta do agribusiness do açúcar e álcool no Brasil. In: VII Congresso da ALASRU, 2006, Quito/Equador. Anais do VII Congresso da ALASRU/GT 4, 2006. v. 1. p. prelo.

SZMRECSÁNYI, Tamás. O Planejamento da Agroindústria Canavieira do Brasil (1930-1975). São Paulo: Hucitec/Unicamp, 1979.

THOMAZ JR, Antônio. A Territorialização do Monopólio: o caso das agroindústrias em Jaboticabal. Dissertação (Mestrado em Geografia Humana). São Paulo:DG/ FFLCH/USP, 1988.

- Por Trás dos Canaviais, os "nós da cana" : a relação capital $\mathrm{x}$ trabalho e o movimento sindical dos trabalhadores na agroindústria canavieira paulista. 1 ed. São Paulo: Annablume Editora / Fapesp, 2002.

VASCONCELLOS MARTINS, Roberto. Fazendas de São Simão. Meados do século XIX., 1998.

VETTORASSI, Andréa. Espaços Divididos e Silenciados: Um estudo sobre as relações sociais entre nativos e os “de fora” de uma cidade do interior paulista. Dissertação (Mestrado em Ciências Sociais). São Carlos: UFSCar,2006

VICHNEWSKI, Henrique Telles. As Indústrias Matarazzo no interior paulista: Arquitetura Fabril e Patrimônio Industrial (1920-1960). Dissertação (Mestrado em História) Campinas: IFCH / UNICAMP, 2004

WELCH, Clifford \& SALGADO, L.. Lutas Camponesas no interior paulista: memórias de Irineu Luís de Moraes. Rio de Janeiro: Paz e Terra,1992.

ZAMBONI, Sílvio Perini. O Café no Norte Paulista: A Crise de 1929 na Fazenda Dumont. Dissertação (Mestrado em Economia Agrária). Piracicaba: Escola Superior de Agricultura “Luiz de Queiroz”/ USP, 1979.

\section{Periódicos}

Anuário Açucareiro para 1935. Edição de Brasil Açucareiro. Rio de Janeiro: IAA. Anuário Açucareiro para 1936. Edição de Brasil Açucareiro. Rio de Janeiro: IAA. Anuário Açucareiro para 1937. Edição de Brasil Açucareiro. Rio de Janeiro: IAA. Anuário Açucareiro 1938. Rio de Janeiro: IAA. 
Anuário Açucareiro 1939. Rio de Janeiro: IAA.

Anuário Açucareiro1941. Ano VII. Edição de Brasil Açucareiro. Rio de Janeiro: IAA, 1941.

Anuário Açucareiro 1942. Rio de Janeiro: IAA.

Anuário Açucareiro 1943 1944. Anos IX e X (1943-1944). Rio de Janeiro: IAA.

Anuário Açucareiro. Anos XI a XIII (1945 - 47). Rio de Janeiro: IAA.

Anuário Açucareiro (1948/49). Rio de Janeiro: IAA.

Anuário Açucareiro (1949/50). Rio de Janeiro: IAA.

Anuário Açucareiro (1950/51). Rio de Janeiro: IAA

Anuário Açucareiro. Anos XVII (1951/ 52). Rio de Janeiro: IAA.

Anuário Açucareiro. Anos XVIII (1953/ 54/ 55/ 56). Rio de Janeiro: IAA.

Anuário Açucareiro (Safras 1956/57 -1959/60). Rio de Janeiro: IAA, 1961.

Anuário Açucareiro (Safras 1960/61 -1965/66). Rio de Janeiro: IAA, 1967.

Censo Agropecuário de 1995-1996

Censo Demográfico IBGE. Vários Anos.

Caros Amigos Especial: Reforma Agrária - Vai ou Não Vai? São Paulo, n¹8, p.245, 18/09/2003.

“EEPG Fazenda Amália” 1942-1992 - 50 anos.

Enciclopédia dos Municípios Brasileiros, Estado de São Paulo. Estado de São Paulo FIORAVANTI, Carlos. Os Arquitetos da Nova Cana. Pesquisa FAPESP, n ${ }^{0} 59$

São Paulo: Novembro de 2000.

Guia Cultural do Estado de São Paulo, 2003.

MATARAZZO 100 ANOS, s.d.

O Observador: Serrana , Ano 35, Nº 416, 11/09/2006, p. 5

Revista Veja, de 24 de maio de 1989, p.102-110.

\section{Sítios}

Estações Ferroviárias: Disponível em < www.estacoesferroviarias.com.br $>$. Acesso em 21 abr. 2007

IBGE: www.ibge.gov.br. Vários acessos

Isto é Dinheiro: www.terra.com.br/istoedinheiroe /442/economia/era_alcool.htm Acesso em 25 jan. 2007. 
Prefeitura Municipal de Santa Rosa de Viterbo: Disponível em http://www.santarosa.sp.gov.br. Acesso em 21 abr. 2007

Resolução No 401 de 18 de outubro de 2000, da Agência Nacional de Energia Elétrica, disponível em : $<>$. Acesso em / / .

Sociedade Rural Brasileira: <www.srb.org.br> . Acesso em 25 jan. 2007

Unica (União da Agroindústria Canavieira do Estado de São Paulo). Vários acessos.

\section{Jornais}

\section{O Jornalzão}

O Jornalzão, Santa Rosa de Viterbo, ano 1, nº 4, p.1, 15 dez. de 1994.

O Jornalzão, Santa Rosa de Viterbo, ano 4 , nº. 137, p. 3, 19 jan. 1998.

O Jornalzão, Santa Rosa de Viterbo ano 4, n 141, p, 1, 14 mar.1998.

O Jornalzão, Santa Rosa de Viterbo, ano 4, nº 143 , p. 1, 11 abr.1998.

O Jornalzão, Santa Rosa de Viterbo, ano 4, nº.144, p. 1, 25 abr.1998.

O Jornalzão, Santa Rosa de Viterbo, ano 5, nº 177 p. 5, 8 mai.1999.

O Jornalzão, Santa Rosa de Viterbo, ano 5, n 200, p. 5, 16 out. 1999.

O Jornalzão, Santa Rosa de Viterbo ano 7, n 279, p. 1, 19 mai. 2001.

O Jornalzão. Santa Rosa de Viterbo, p. 13, $1^{\circ}$ set. 2001.

O Jornalzão, Santa Rosa de Viterbo ano 8, n 305, p. 1, 17 nov.2001

O Jornalzão, Santa Rosa de Viterbo, ano 8, n 331, p.7, 18 mai. 2002.

O Jornalzão, Santa Rosa de Viterbo, ano 8, n 346, p.31, 31 ago. 2002.

O Jornalzão, Santa Rosa de Viterbo, ano 9, $\mathrm{n}^{0}$. 366, p.17, $1^{\mathrm{o}}$. fev.2003.

O Jornalzão, Santa Rosa de Viterbo, p.26, 1º abr. 2006.

\section{O Santa Rosa}

O Santa Rosa, Santa Rosa de Viterbo, ano 1, n¹9, p.3, 29 set.1990.

O Santa Rosa, Santa Rosa de Viterbo, ano 1, n 23, p. 1, 24 dez. 1990.

O Santa Rosa, Santa Rosa de Viterbo, p. 3, 10 ago 1991.

\section{O Santarrosense}

O Santarrosense, Santa Rosa de Viterbo, ano 1, nº 6, p.3, abr. 1987. 


\section{Santa Rosa Notícias}

Santa Rosa Notícias; Santa Rosa de Viterbo, ano 1, nº 6, p.1, 19 jan. 1980.

Santa Rosa Notícias, Santa Rosa de Viterbo, ano 3, nº 57, p.4, 7 mai.1982.

Santa Rosa Notícias, Santa Rosa de Viterbo, ano7, nº 132, p. 6, 7 ago. 1986.

Santa Rosa Notícias, Santa Rosa de Viterbo, ano 9, nº.156, 12 abr.1988.

Santa Rosa Notícias, Santa Rosa de Viterbo ano 11, nº 173, p. 1, 4 set. 1990.

Santa Rosa Notícias, Santa Rosa de Viterbo, ano 11, nº 193, p.7, 7 mai.1994.

\section{Edições digitais:}

\section{O Jornalzão (Santa Rosa de Viterbo)}

Disponível em <http://www.ojornalzao.com.br> Acesso em 18.4.2005.

Disponível em <http://www.ojornalzao.com.br> Acesso em 25 abr.2006

\section{A Cidade (Ribeirão Preto/SP)}

Jornal A Cidade, site: www.jornalacidade.com.br, edição digital de 25/04/2006. Acesso em 25/04/2006)

\section{Iconografia}

Arquivo de Fotografias Aéreas Obliquas 1939/1940, do Instituto Geográfico e Cartográfico.

Fundação Cultural de Santa Rosa de Viterbo. 